



A MONOGRAPH OF THE PETRELS 


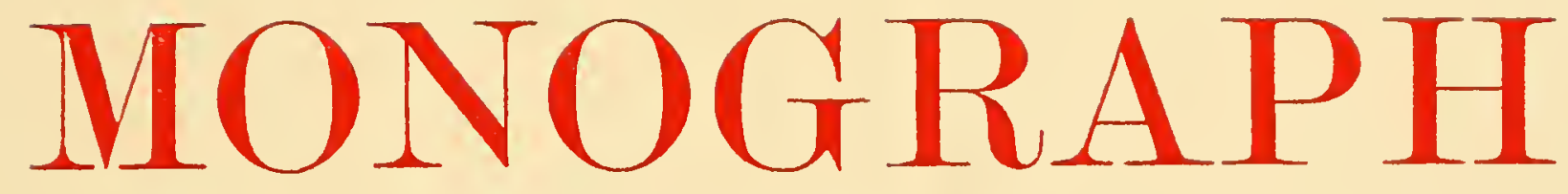

OF THE

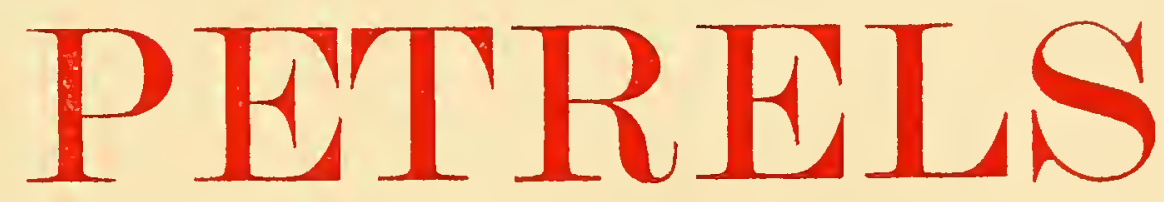

(ORDER TUBINARES)

B Y

FREDERICK DU CANE GODMAN D.C.L. F.R.S.

PRESIDENT OF THE BRITISH ORNITHOLOGISTS' UNION

WITH HAND-COLOURED PLATES

BY J. G. KEULEMANS

WITHER B Y \& CO.

326 HIGH HOLBORN LONDON

$1907-1910$ 
The number of copies of this work is strictly limited to two hundred and twenty-five, of which this copy is No. 39 
To My Wife

\section{ALICE MARY GODMAN}

This Book is Dedicated

in acknowledgment of the assistance

which she has rendered

in its preparation 


\section{ERRATA ET CORRIGENDA.}

Page 22, line 9 from top.-For "Oceanitis" read "Oceanites."

Page 48, lines 10 and 11 from top.-The references to Oceanites wilsoni, Giglioli, are incorrectly placed under O. GRACILIS, and belong to O. OCEANICUS, p. 41 .

Page 99, line 3 from top. - Puffinus edwardsi, add to the references: Salvad., Ann. Mus. Civ. Genova (2), XX., p. 302 (1899).

Page 101, line 2 from top.-For "Pink-footed Shearwater " (Puffinds creatopus) read "Coubs's Shearwater." The first name to be applied to Puffinus CARNEIPES ONly (p. 142).

Page 108, line 3 from bottom.-For "The figure " read "The front figure."

Page 126.-Puffinds obscurus. Add to the synonymy: Puffinus tenebrosus (Natterer), Pelzeln, Ibis, 1873, p. 47 ; Finsch, Journ. Mus. Godeffr., XII., p. 40 (1876).

Page 258, line 17 from bottom.-For "February 4th" read "September 4th."

Page 260, line 4 from top.-For "Thallassidroma" read "Thalassidroma."

Page 265, line 10 from top.-For "l'isle" read " l' $\imath$ le."

Page 271, bottom line.-For " ashy-grey" read "smoky-brown."

Page 273, line 10 from top. - For " $P$." read " $F$."

Page 298, line 11 from bottom.-For " $P$. ariel" read "P. brevirostris."

Page 298, line 2 from bottom.-For "received" read "accepted."

Page 307, line 9 from top.-For "Halodroma" read "Haladroma."

Page 328, line 7 from top.-For "under" read "upper."

Page 329, line 7 from bottom.-For "surface" read " under surface."

Page 332, line 14 from top.-For " nigrie" read "nigris."

Page 334, line 15 from bottom.-For " 19.51 " read "19.5."

Mr. Joseph Grinnell's "Report on the Birds recorded during a visit to the Islands of Santa Barbara, San Nicolas and San Clemente, in the spring of 1897 " (Pasadena Acad. Sci., publ. No. 1, Aug., 1897) has been overlooked by me. He enumerates (l.c., pp. 24, 25) five species of Tubinares (amongst a total of twenty-four water-birds) from these islands off the coast of California, and references to his work should be added: Diomedea nigripes (p. 332), Puffinus creatopus (p. 101), P. opisthomelas (p. 109), P. griseus (p. 145), and Oceanodroma melania (p. 24). 


\section{LIST OF CONTENTS.}

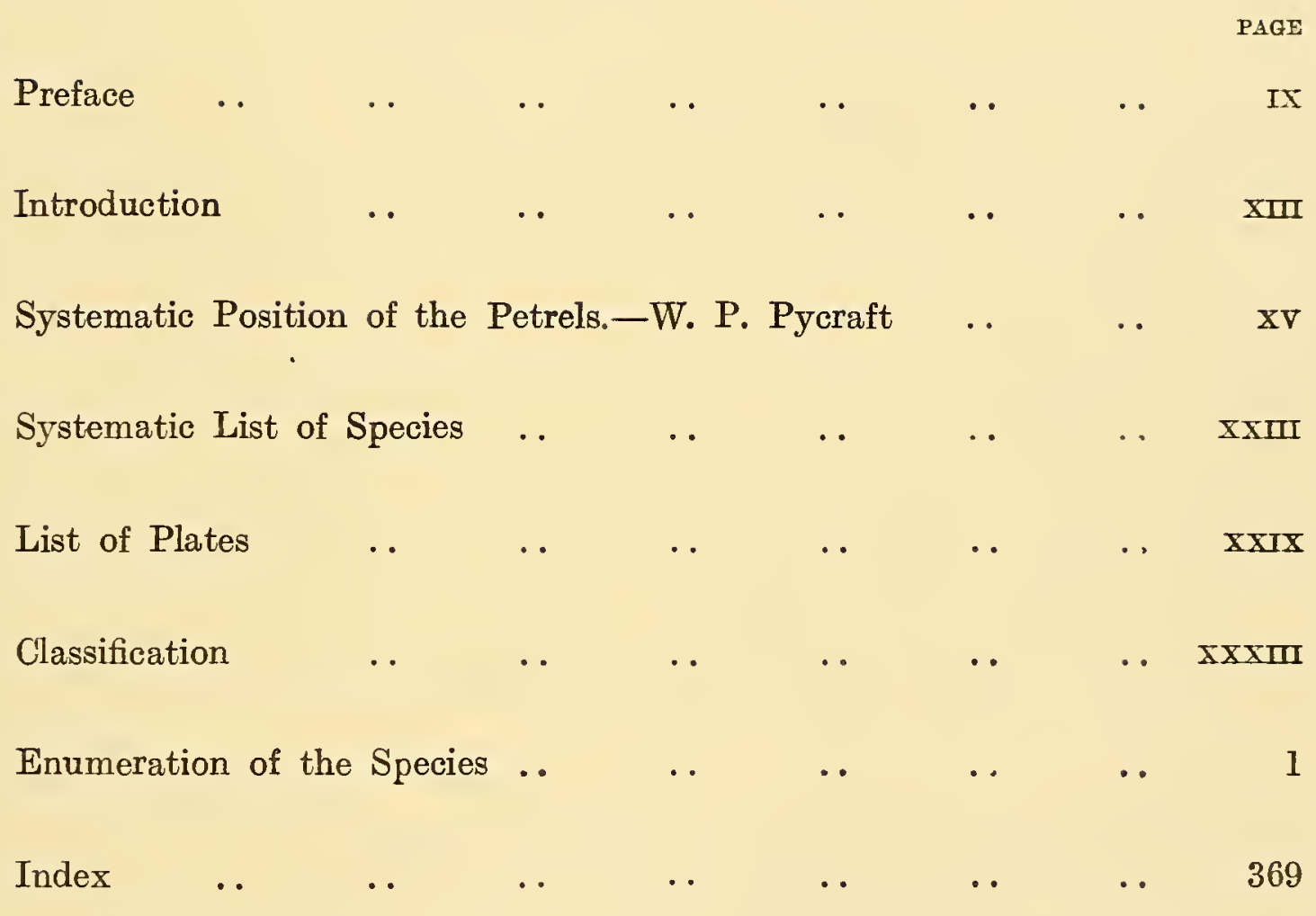





\section{PREFACE.}

MY late friend and colleague Osbert Salvin for many years made a special study of the Order Tubinares, and together we collected specimens of Petrels from all available sources, thus amassing a large and valuable series, which, with the rest of our ornithological collection, numbering some 80,000 specimens, we finally presented to the Natural History Museum.

It was Salvin's intention on the completion of the "Tubinares" for the twenty-fifth volume of the Catalogue of Birds in the British Museum, to write a fuller account of the Petrels, and publish it as a Monograph, illustrated by coloured figures of each species; for that purpose we had some forty plates prepared by Mr. Keulemans, but Salvin's untimely death, in June, 1898, put an end to this project.

Although naturally anxious to carry out my friend's intention, a good deal of extra work was now thrown upon my shoulders, and for some years I was too much engaged with the "Biologia Centrali-Americana" to embark on any fresh undertaking. As I hoped, however, at some future date to have more leisure, most of the remaining plates (106 in all) were drawn and coloured under my supervision, so as to be ready should opportunity occur. Having brought the unfinished volumes of the "Rhopalocera" and the "Aves" for the "Biologia" to a conclusion, my attention was again turned to the long intended Monograph, and with the able assistance of Dr. R. Bowdler Sharpe, of the Natural History Museum, I no longer hesitated to make a commencement.

Professor Newton, one of our highest authorities on the Aves, writing to Sir Walter Buller, said, "All Petrels are puzzling in almost every way," and he goes on to say that though Salvin solved some of the puzzles, he doubted whether, in spite of the trouble he had taken and all the opportunities at his command, he would himself admit that he had completely disposed of all the difficulties of determination. Unlike my late colleague, I had made no special study of the Order, and had it not been for the promise of Dr. Sharpe's assistance, it would have been presumptuous in me to have undertaken so difficult a task.

I have endeavoured to carry out the work on the lines projected by Salvin. Taking the Catalogue of Petrels as his guide, he proposed to omit the host of references belonging to the various species, and to quote only such as belonged to their history and distribution. 


\section{MONOGRAPH OF THE PETRELS.}

The classification here adopted will be found almost identical with Salvin's, and, indeed, with the exception of a slight alteration of some of the keys to the species, as little as possible has been done to deviate from his work.

The chief sources whence Salvin derived the material for his Catalogue were enumerated in the Introduction to that work, but since 1896 considerable additions to the National Collection have been made through the several expeditions sent to the Antarctic regions, amongst which I may mention the voyages of the "Discovery," the "Southern Cross," the "Scotia," and the cruises of the "Valhalla," as well as the expedition sent to the Hawaiian Islands by the Hon. Walter Rothschild; these together have considerably increased our knowledge of the distribution of the Petrels.

I am only too well aware of the many imperfections in this Monograph, but truly I may say that no pains have been spared in collecting all the information possible both from published accounts and from observers direct, and if the result now obtained should prove of assistance to future students of the Tubinares I shall feel that I have not laboured in vain.

Mr. Pycraft, a high authority on the subject, has given his views in the Introduction as to the position the Order should occupy in the systematic classification of birds. He has added a summary of his examination of the osteological, anatomical and external characters, and it is satisfactory to find that he arrives at much the same conclusion as Garrod, Forbes, Milne-Edwards and Huxley, placing the Petrels near the "Steganopodes" and "Herodiones," quite apart from the Gulls and Terns. I should like to take this opportunity of tendering him my sincere thanks for the trouble he has taken in preparing this essay, as well as for the many hints he has given me throughout the progress of this work.

I have also much pleasure in acknowledging the assistance afforded me by my friends and colleagues in various parts of the world. I am specially grateful to the Hon. Walter Rothschild for having placed the whole of his fine collection of Petrels at my disposal for examination, as well as for hls advice on several important points, and to Dr. Hartert, the Curator of the Tring Museum, I am also under obligation for much assistance. My thanks are due to Mr. W. Eagle Clarke, of the Edinburgh Museum, who has lent me the coloured drawings of the soft parts of many Petrels made by Dr. W. S. Bruce during the Scottish Antarctic Expedition, as well as for his valuable notes in the "Ibis" and elsewhere. I must not omit to mention the help which my old friend Count Salvadori has rendered me, more particularly by the loan of the new species procured during the voyage of the "Magenta." Dr. Reichenow kindly Jent me his type of Diomedea platei, from the Berlin Museum, and I am thus able to give a figure of it. Mr. T. Parkin has also sent me many notes of birds observed by him during his voyage in the Southern Oceans. I must also express my indebtedness to Dr. Péringuey, Director of the 


\section{PREFACE.}

South African Museum, for some interesting specimens of Petrels, with their eggs, from Tristan da Cunha, which he has lately sent me. My acknowledgments are likewise due to the authorities of the Pauahi Museum at Honolulu for the loan of the type of Estrelata newelli. There are others whose names are mentioned throughout the work, to all of whom I return my grateful thanks. Most of my readers will, I feel sure, fully appreciate Mr. Keuleman's excellent drawings; while the colouring of the plates has been entrusted to Dr. Sharpe's talented daughters, whose work will speak for itself.

It only now remains for me to acknowledge my indebtedness to my Publishers, Messrs. Witherby \& Co., for their care in the production of the work, and for the patience they have exercised, notwithstanding the many delays unavoidably caused by recurring illness.

On the eve of completing this work I have to deplore the sudden death of Dr. Sharpe, a loss to the ornithological world at large, and as a collaborator one who has rendered me invaluable aid in placing his extensive knowledge most generously at my disposal. It is, however, a source of gratification to me that he lived to see the practical conclusion of the Monograph and to revise the proofs of all but the last few pages.

F. D. G.

March 29th, 1910. 



\section{INTRODUCTION.}

Petrels apparently belong to an ancient race of birds, as their remains have been found in a fossil state in various parts of the world, though mostly in superficial deposits; Diomedea anglica, however, is known from the Red Crag of Norfolk (Lydekker, Cat. Fossil Birds in Brit. Mus.).

The Order Tubinares embraces Families differing in external appearance to an extraordinary degree, and varying in size from the tiny Storm Petrel to that of the Wandering Albatros. The greater number of the species are of powerful flight, fitted to combat oceanic storms, in which the larger ones in particular appear to delight.

The members of the Family Pelecanoididæ, however, which are peculiar to the southern oceans, and resemble the Little Auk of the northern seas both in appearance and habit, frequent sheltered bays in preference to open waters, and procure their food by diving, for which they are specially adapted. Notwithstanding these wide differences, Petrels may at once be distinguished from all other birds by their prominent tubular nostrils, and by their bills, which consist of several horny pieces separated by deep grooves.

Petrels are dispersed throughout all the oceans of the world, penetrating to the Ice Barrier at both poles, though they are probably more numerous in the southern than in the northern hemisphere. They are purely oceanic wanderers, and unless driven ashore by storms, seldom, if ever, come to land except for the purpose of breeding, and then they invariably select unfrequented rocks and islands difficult of access. All the smaller species nest in burrows in the ground, or in the clefts of rocks, and are more or less crepuscular in habit.

Considering the vast number of these birds inhabiting the seas, it seems remarkable at first sight that so much difficulty is experienced by our Museums in obtaining examples, but this, of course, is due to their mode of life, and the great difficulty in securing specimens at sea. It must also be remembered that many species resemble each other very closely and the slight differences between them are not easily identified from the deck of a passing ship, even by a competent observer, hence much that has been written on the occurrence of certain birds in stated localities must be received with caution.

With regard to the plumage, much more information is still required as to the various stages through which the birds pass before reaching the adult. Some doubtless assume the mature plumage as soon as they are fully grown, while others, such as certain of the Albatroses, take years before they acquire their full dress. Again, much remains to be learned respecting the colour of the legs and bill, 


\section{MONOGRAPH OF THE PETRELS.}

which in some species appears brighter during the breeding season, but as these parts change colour in the dry skin, accurate information on these points can only be obtained from living or freshly killed specimens.

A marked peculiarity of these birds is the habit of ejecting a fœtid fluid from their nostrils, which is apparently used by certain species as a means of defence, when it can be discharged to a distance of three feet at the approach of any intruder. Owing to the introduction of the mongoose and other small carnivorous mammals into their breeding haunts, some species, such as Estrelata jamaicensis and newelli, have already been completely exterminated, and others appear to be in danger of extinction. The habit of some species of nesting in immense colonies is also leading to similar results, as, for purposes of food, the eggs are taken and young frequently robbed and killed in such countless thousands that extermination becomes only a matter of time.

In his preliminary remarks on the Order Tubinares in the twenty-fifth volume of the "Catalogue of Birds," Salvin has reviewed the previous attempts to classify the Petrels, quoting the characters propounded by Fürbringer (1888), Seebohm (1890), Bowdler Sharpe (1891), and Gadow (1892). Of the work of W. A. Forbes, he wrote as follows :-

"The late William Alexander Forbes's Memoir entitled 'Report on the Anatomy of the Petrels' (Tubinares) collected during the voyage of H.M.S. 'Challenger' (see the Report of the Scientific Results, etc., Zoology, Vol. IV., Part XI., 1882), gives by far the most complete account of the anatomy of this Order, discusses the relationship of a large number of species representative of many genera, gives a good résumé of the literature of the subject, and the author's views as to the relationship of this to other Orders of the Class Aves.

"As the whole of the spirit-specimens possessed by me at the time were placed at Forbes's disposal and were used in compiling his Memoir, I have little to say on this branch of the subject beyond pointing out that I have ventured to depart to some extent from Forbes's classification in the present 'Catalogue.' In doing so, I have to a great extent returned to the older plan of keeping the Albatroses distinct from the rest of the Petrels, and in restoring Forbes's Oceanitidae to the neighbourhood of the genus Procellaria. That such an arrangement is more convenient can hardly be doubted, and I think it can be justified.

"Regarding the position of the Tubinares in the Systema Avium much difference of opinion has existed, and the final disposition of the Order is hardly yet established. Most authors placed it in juxtaposition to the Larido, but this allocation was objected to by Garrod and Forbes, who asserted that the Steganopodes and Herodiones, as understood by them, are its nearest allies, thus confirming the suggestions to that effect advanced by l'Herminier, Milne-Edwards, and Huxley."

I am greatly indebted to Mr. W. P. Pycraft for the following chapter, which contains some valuable and original observations. 


\title{
ON THE SYSTEMATIC POSITION OF THE PETRELS.
}

\author{
BY \\ W. P. PYCRAFT, F.Z.S., A.L.S., Erc.
}

Not the least interesting feature of the Petrels is the fact that, superficially, they bear an undoubtedly close likeness to the Gulls. By the earlier Ornithologists, and even by some at the present day, this likeness has been taken to indicate the close relationship of the two Orders. As a matter of fact, this resemblance is due entirely to convergence, or "homoplasy." That is to say, it is due to the action of a similar environment on fundamentally similar structures. The Owls and the Accipitres afford a similar case.

But while the Gulls have acquired the ability to roam inland, finding an ample subsistence, the Petrels are, without exception, marine, coming ashore mainly for breeding purposes.

The Gulls, in the number and coloration of their eggs, and in the condition of their young at birth, resemble the Charadriiformes, of which, indeed, they are unquestionably highly specialized members. The Petrels, on the other hand, lay but a single egg, which is white, in some species relieved by a few frecklings of red spots arranged zone-fashion at one end. This egg, save in the Albatroses, which are nest-builders, is deposited in a burrow, or under ledges of rock and similar crevices. The young when hatched are blind, and remain long helpless in the nest: while their downy colouring differs materially from that which is observed in Charadriiformes, as will be shown presently.

In the following pages divergence between the Gulls and Petrels will be set forth, at any rate in broad outline. The facts selected for mention here are such as have a more or less important bearing on questions of taxonomy; purely morphological details are for the most part omitted, as being foreign to the aims of the present work. But those who desire further information on points raised 


\section{MONOGRAPH OF THE PETRELS.}

in these pages should consult the splendid Monograph of W. A. Forbes ("Challenger" Reports, Vol. IV., Part XI.), or the various treatises quoted in the following pages.

\section{External (Exoskeletal) Characters.}

In the matter of the pterylosis of the Petrels much work remains to be done. The little that has been published on this theme is chiefly remarkable for its inaccuracy. All who have written on the subject seem, as usual, to have derived their information from Nitzsch, who, having many difficulties to contend with in the way of obtaining fresh material, was frequently wrong in his interpretation.

Without entering into a detailed description of any particular species it will suffice to mention the principal peculiarities of the several tracts in a few widely distinct species.

In the smaller and, I presume, the more primitive types, the spinal tract is very narrow, and is traversed by a linear ephippal space extending from the interscapular region to the level of the middle region of the pre-ilium. The ventral tract is also narrow, and passes on each side, in the abdominal region, into a very narrow band of feathers enclosing a large apterium mesogastroei.

It would seem that in all the other Petrels belonging to the Procellariina, in the Pelecanoidince, and in the Diomedeidce, the tracts, both dorsal and ventral, were conspicuously broad, the spinal tract passing backwards, on either side, to blend with the femoral tract. In Puffinus anglorum the spinal tract is solid-that is to say there is no ephippal space. In Prion and Pelecanoides, on the other hand, and probably in the majority of genera, this space is fairly well marked. In Pelecanoides the tract on each side of this space is excessively broad.

In the Albatroses the spinal tract has always been described as interrupted, as being forked caudad of the scapulæ, the rami of the fork embracing the fore end of the median hinder moiety of the tract. This is not so. In Diomedea exulans, for example, the spinal tract is continuous, extremely broad, and embraces a very narrow ephippal space. Caudad the tract fuses with the femoral tract. The ventral tracts are broad, and the median abdominal space (apterium mesogastrœi) is very narrow.

The wing in all Petrels is diastataxic or "aquintocubital." Owing to differences in the relative lengths of the outermost primaries, the contour of the wing varies, but in all the Petrels, apparently, the secondaries are very short, not greatly exceeding their major coverts in length. The intermost primary is reduced to the condition of a remicle, much shorter than its covert. In all there are 11 primaries; while the secondaries range from 13 to 40, the latter obtaining only in the Albatroses. The carpal remex and carpal covert are large. The major coverts of the hand are large, those of the secondaries small, though from the narrowness of the remiges they appear 


\section{SYSTEMATIC POSITION OF THE PETRELS.}

unusually long, as they conceal all but the terminal sixth of their respective quills. The sixth major covert of the secondary series is slightly shorter than the fifth on the one side and the seventh on the other.

The sixth covert of the median series is also slightly shorter than the fifth on the one side, and the seventh on the other. The overlap of this series is distal. There are from three to four rows of minor coverts, all having a distal overlap.

The parapteron and hypopteron in the Procellariidae are moderately welldeveloped, but the function of closing the gap between the innermost secondaries and the body, during flight, is really performed by the humerals (scapulars). In the Diomedeidce, however, wherein the humerus is of great length, the parapteron and hypopteron attain their maximum development, and act with, and ancillary to, the humerals (scapulars).

The oil gland is tufted. The hyporhachis is small.

The podotheca is covered by irregular hexagonal scutes, except in the case of the two small groups referred to on page $x$ vII, wherein the scutellæ are transversely oblique in arrangement. The hallux is vestigial, and is sometimes wanting, as in Pelecanoides.

The Rhamphotheca is compound, showing a well-defined Laminicorn, Culminicorn, Rhinotheca, and Dertrum. The nasal apertures are paired, and may open on the culmen, as in the Procellariidce, or on either side thereof as in the Diomedeidce.

The down-feathers in the adult are distributed all over the body: each has a well-developed rhachis and after-shaft. The rami are long, marked by alternate hyaline and pigmented areas, giving a jointed appearance under the microscope. Cilia are rare and minute, visible only under high magnification, and apparently confined to the innermost radii of the proximal rami. These differ markedly from the similar feathers of the Charadriiformes-and therefore from the Laridce, with which, by some authors, the Petrels have been associated.

\section{NEOSSOPTYLES.}

The nestling down of the Tubinares agrees with that of the Sphenisciformes, in that two distinct generations are developed-a protoptyle, and mesoptyle generation-before the appearance of the feathers or Teleoptyles.

In both Petrels and Penguins the two generations of Neossoptyles follow one another by one continuous process of growth; there is, however, a pause between the two, as indicated by the cessation of rami along the axis common to the two feathers, except in the Albatroses, wherein it is extremely difficult to distinguish the two generations.

Between the mesoptyle generation and the first teleoptyle generation there 


\section{MONOGRAPH OF THE PETRELS.}

is absolutely no growth pause, the rami of the one passing directly, insensibly, into those of the other and, so far as I know, this peculiarity is met with only among the Petrels and has not hitherto been described.

Pterylologically the Petrels approach the Ciconiiformes.

\section{Osteologioal Characters.}

Osteologically the Petrels can readily be divided into two families-Procellariidce and Diomedeidos; and this, whether the evidence is taken from the skull, the trunk, or the limbs. The nature of this evidence is set forth in detail in my paper in the Proceedings of the Zoological Society for 1899.

The Procellariidoe must, it seems to me, be divided into two sub-familiesProcellariinoe and Pelecanoidino. The members of the last stand well apart from those of the first named, differing conspicuously in the characters of the skull. Other well-marked differences, such as the relatively great elongation of the sternum, the flattening of the wing-bones; and the elongation of the ribs and pelvis are to be set down to adaptation, and are therefore of no importance from a systematic point of view. But in the great width of the basi-temporal platform, and the prominent basipterygoid processes, the Pelecanoidinoe stand alone, recalling the Penguins in these particulars and in the form of the pterygoids.

Macronectes is undoubtedly the most highly specialized of the Procellariinoe and herewith must be associated Fulmarus, Priocella, Thallassceca, Pagodroma and Daption, an arrangement first propounded by Forbes. Prion, in many respects resembles Daption, but in its pelvis recalls Bulweria and Estrelata.

Procellaria, Halocyptena, and Oceanodroma on the one hand, and Fregetta Pelagodroma, Cymodroma, Oceanites, and Garrodia on the other hand, seem to represent two well-marked groups standing somewhat apart from the rest of the Procellariince, but not sufficiently distinct to deserve the rank of a sub-family; and certainly not family rank, as was accorded by Forbes.

The Diomedeidoe have undergone specialization in many ways, in regard to the skeleton as in other characters. The palate shows this specialization very markedly, for though schizognathous, it approaches very near to becoming desmognathous. Basipterygoid processes are absent.

The thoracic vertebræ bear no hypapophyses. The corpus sterni is conspicuously pneumatic; and the carina merges into the sternal plate some distance cephalad of the metasternum, while the posterior lateral processes project far beyond the level of the metasternum. The humerus is pneumatic, and the crista inferior is inflated along its preaxial border. The hypotarsus is simple, and the fibular ridge feebly developed. 


\section{SYSTEMATIC POSITION OF THE PETRELS.}

In all these characters the Diomedeidce differ from the rest of the group. Further, this family must be divided into three genera-Diomedea, Thalassogeron and Phoebetria, of which Phoebetria is probably the most primitive.

The evidences of the Ciconiiform affinities of the Petrels pointed out by other writers, are quite borne out by a study of their osteology which, furthermore, supports the contention that we may claim affinities of the Petrels both with the Divers and the Penguins. The last two, it may be remarked, like the Petrels, have schizognathous palates and holorhinal nares and deep supra-orbital grooves. It may well be that these three, with the Ciconiiformes, represent so many branches of a common stock. The fact that, on the whole, the Petrels, osteologically, approach the Steganopodes is quite in accordance with the ancient character of this group. But the Tubinares are apparently older than the Ciconiiformes; at any rate I find that the head of the embryo Pelican bears a most striking likeness to that of a Petrel! And this both in the form of the Rhamphotheca and of the cranial characters.

Osteology lends no support to the contention that the Petrels are related to the Gulls, a contention now generally abandoned, though still finding champions. The likeness between the two groups is one of homoplasy only. That is to say, the likeness is superficial and wrought by the demands of a like physical environment. Though leading a precisely similar life the Gulls have no hypapophyses in the thoracic vertebræ, for instance, while, further, the Gulls are schizorhinal and schizognathous. The Petrels, like the Penguins and Divers, are holorhinal and schizognathous. Moreover the schizognathism of the Petrels differs in kind from that of the Gulls.

\section{Myological Characters.}

It would be foreign to the purpose of this summary to pass in review the general myological characters of the Petrels. Those which seem to serve most decisively as signs useful for taxonomic purposes are to be gleaned from the muscles of the wings and thighs.

The "Great Pectoral " is divisible into two layers, by an interposed tendon as in the Steganopodes and Storks, while in the presence of what Forbes calls a pectoralis tertius, and Gadow the pars sterno-coraco-clavicularis of the supracoracoideus, the Petrels are peculiar. An expansor secundariorum is found only in Oceanites and its immediate allies. As in the Gulls, the tensores patagii are complicated; but the complexity seen in the Petrels is unique in character. In a considerable number of Petrels the brevis tendon develops a peculiar ossicle, met with again among the Steganopodes, and curiously enough in Merops! Into the nature of this ossicle, its form, and relations, it is unnecessary to enter here; but admirable figures illustrating these points will be found in Forbes's "Memoir of the Petrels" 


\section{MONOGRAPH OF THE PETRELS.}

("Challenger" Reports). No Petrel has a biceps slip, while the triceps itself is somewhat degenerate.

The muscles of the hind-limb vary much. The ambiens is absent only in Fregetta, but in Garrodia and some others, it is degenerate, not crossing the knee. All have a femoro-caudal, but its accessory head is absent in Bulweria and Pelecanoides. The semitendinosus has an accessory head in Oceanites and its allies, but not in other Petrels. The deep flexors blend about half way down the leg, but no slip is ever given off therefrom to the hallux.

\section{Visceral Characters.}

The tongue shows degenerate tendencies, and a consequent considerable range of variation in size, shape, and armature, e.g. in Puffnus brevicauda, Diomedea brachyura, the dorsal aspect may be covered with small conical papillæ, recalling those of the Penguins, wherein these papillæ attain a relatively enormous size; while in others, e.g. Estrelata lessoni and Majaqueus oquinoctialis, these papillæ are limited to the lateral border of the tongue. The inner border of the sheath of the upper jaw may bear long horny lamellæ, as in Prion, or be simply striated, as in Fulmarus.

The proventriculus of the Petrels is enormous, while the gizzard is no less remarkable on account of its small size, and peculiar shape and position.

In the convolutions of the intestines, as Chalmers-Mitchell has demonstrated, the Petrels display strongly marked peculiarities, in their nature akin to the convolutions seen in the Divers, Penguins and Storks, and in no way resembling the type of convolution which obtains among the Grues.

Cæca are extremely reduced in all the Petrels; in Oceanites and its allies, and in Halocyptena they are absent.

The Syrinx shows a wide range of variety in its structural characters, but preserves an underlying resemblance to that of the Sphenisci and the Ciconiiform types, and in no way approaches that of the Lari.

Typically tracheo-bronchial, it has acquired in Pagodroma and Thallassceca, for example, the peculiarities of the bronchial type. But the various modifications which this organ presents in the Petrels being of morphological, rather than taxonomic, interest, the reader is referred to Forbes's Monograph for the detailed description thereof. Suffice it to say that in some genera, notably in Fulmarus, Thalassoeca, and Macronectes, the lower end of the trachea is divided by a median vertical septum, dividing the lumen of the tube into right and left channels as in Penguins. In Macronectes the specialization of the trachea from this point of view attains its maximum, the lower end thereof being cleft to form right and left branches, each continuous with its bronchus. Immediately distad of the cleft, the tube is for a short distance divided by a median septum such as that just referred to, owing, apparently, 


\section{SYSTEMATIC POSITION OF THE PETRELS.}

to the fusion of the inner walls of the apposed paired tracheal rings, which, as they approach the syrinx, become the separate branches just described. Superficially, however, the fusion of these septate rings is so complete that they betray no evidence of their true character, fused paired rings.

The syrinx is supplied with but one pair of intrinsic muscles, which, according to Forbes, are always attached to the fifth bronchial ring. But this interpretation seems open to question.

In some Albatroses, according to Swinhoe, the bronchi are convoluted as in some Storks.

The great size of the olfactory chamber in the Petrel, has been generally overlooked; but in this particular it is significant to note that they approach the Cathartida. 


\section{SYSTEMATIC LIST OF SPECIES.}

\section{Family 1. PROCELLARIIDA.}

SUB-FAMILY 1. PROCELLARIIN Æ.

1. Procellarta, Linn.

PAGE

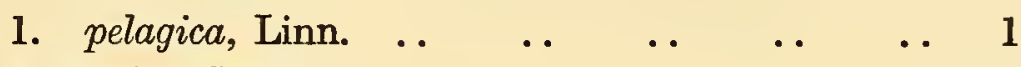

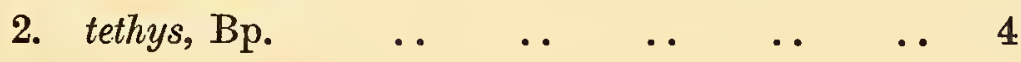

2. Halocyptena, Coues.

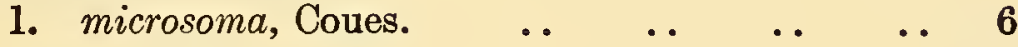

3. Oceanodroma, Reichenb.

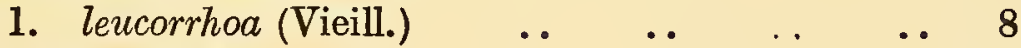

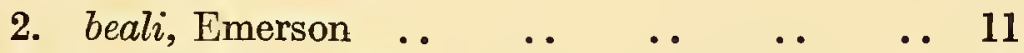

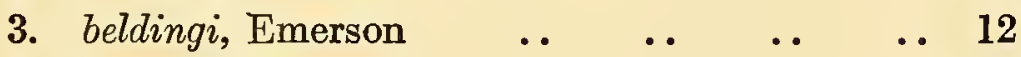

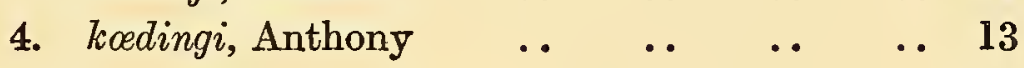

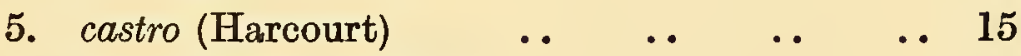

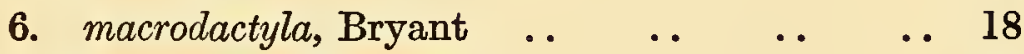

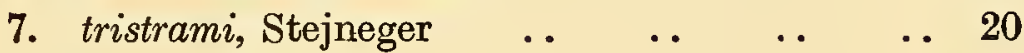

8. melania (Bp.)

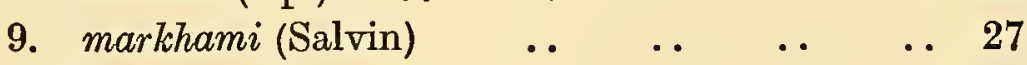

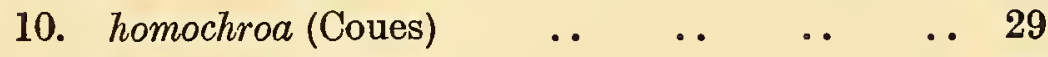

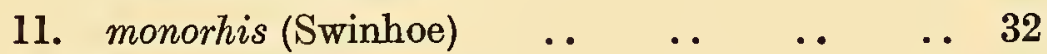

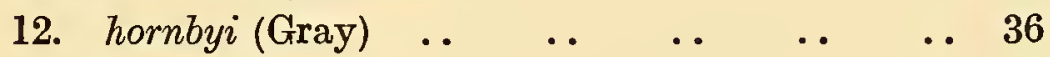

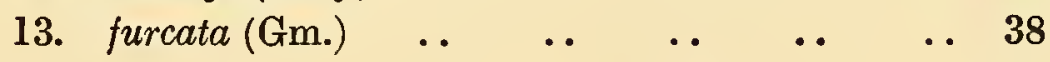

\section{SUB-FAMILY 2. OCEANITIN F.}

4. Oceanites, Keys. und Blas.

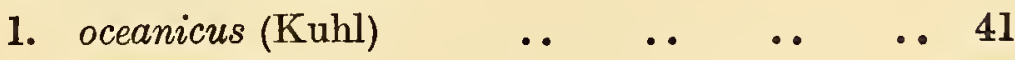

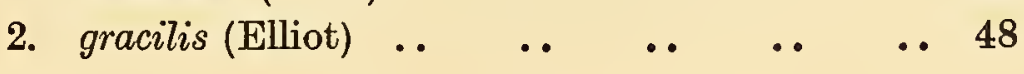

XXIII 
5. Garrodia, Forbes.

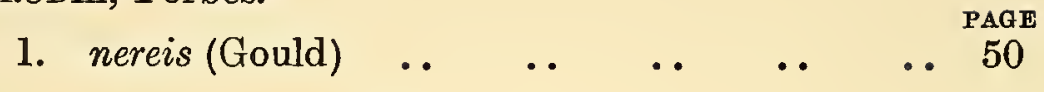

6. Pelagodroma, Reichenb.

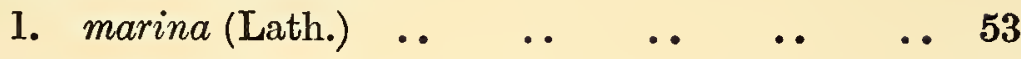

7. Pealea, Ridgway.

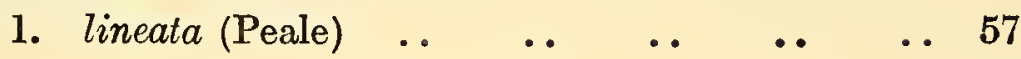

8. Cymodroma, Ridgway.

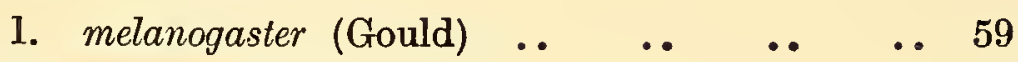

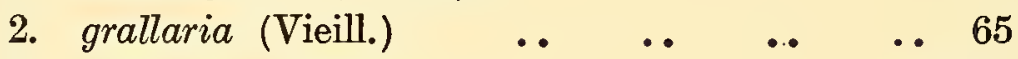

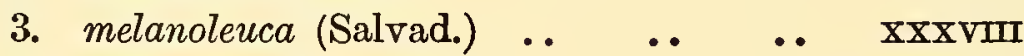

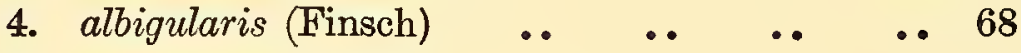

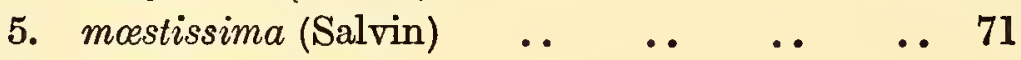

\section{Family II. PUFFINIDA.}

SUB-FAMILY 1. PUFFININ Æ.

9. Puffinus, Briss.

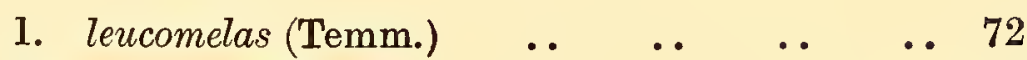

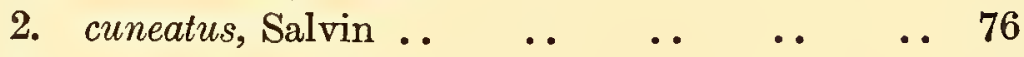

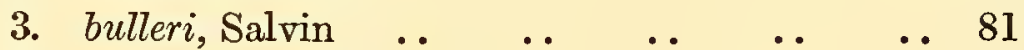

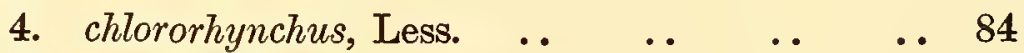

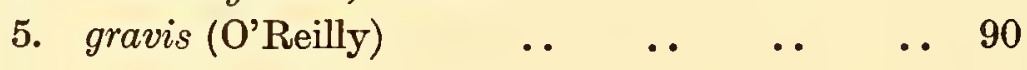

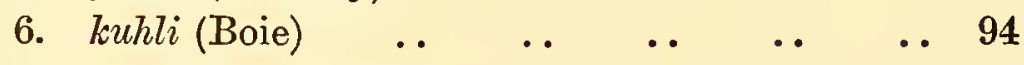

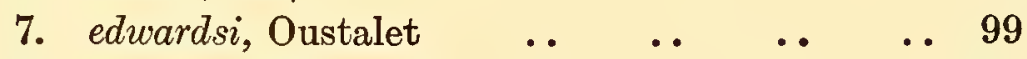

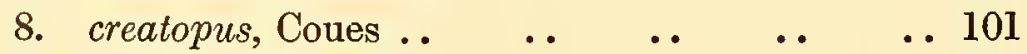

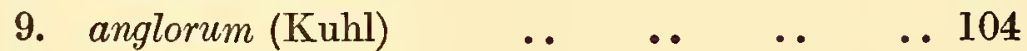

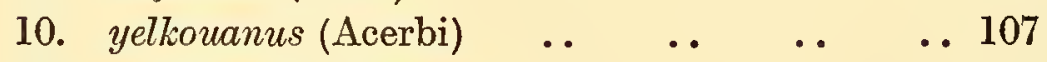

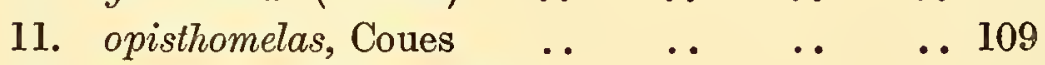

12. auricularis, Townsend .. $\quad \ldots \quad \ldots \quad \ldots 112$

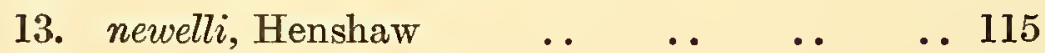

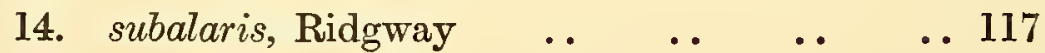

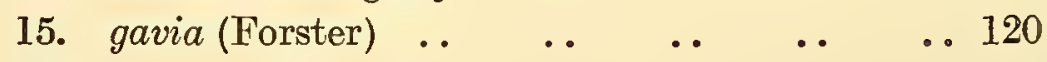

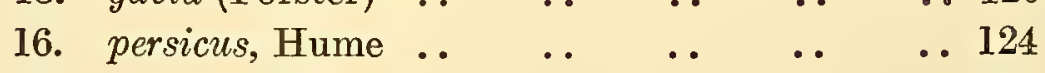

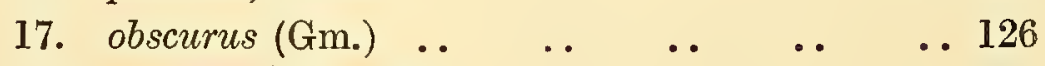

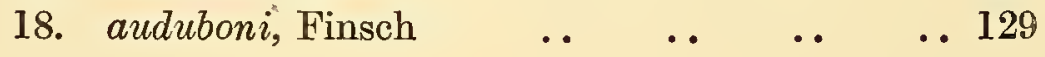

XXIV 


\section{SYSTEMATIC LIST OF SPECIES.}

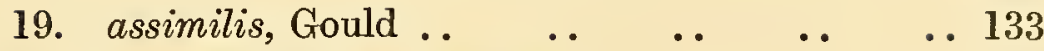

20. elegans, Gigl. and Salvad. $\quad \ldots \quad \ldots \quad \ldots 136$

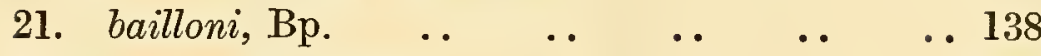

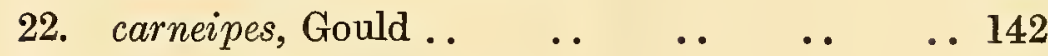

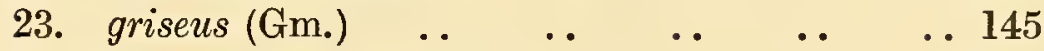

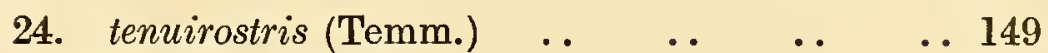

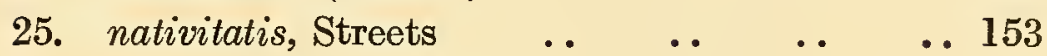

10. Priofnud, Hombr. et Jacq.

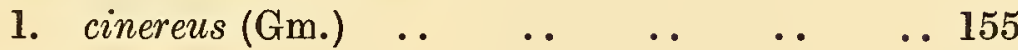

11. Thatassceca, Reichenb.

1. $\operatorname{antarctica}(\mathrm{Gm}.) \ldots \quad \ldots \quad \ldots 161$

12. Priocella, Hombr. et Jacq.

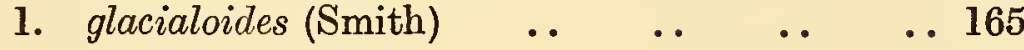

13. Majaqueds, Reichenb.

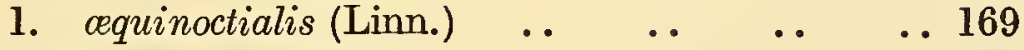

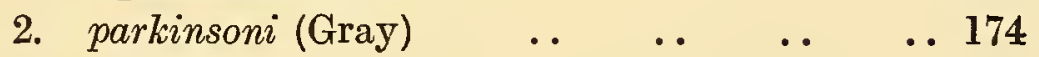

14. Estrelata, Bp.

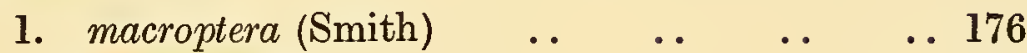

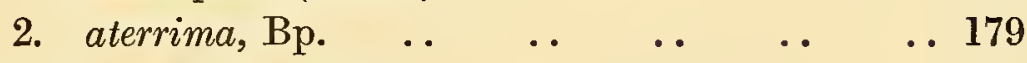

3. lessoni (Garnot) . $\quad \ldots \quad$.. $\quad \ldots \quad$.. 181

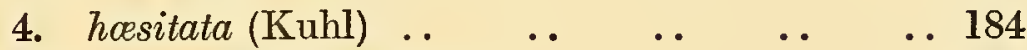

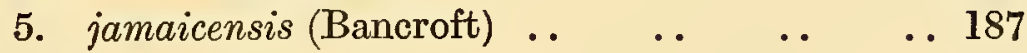

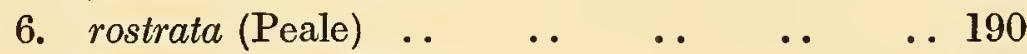

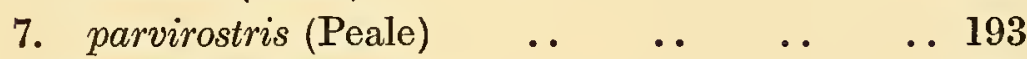

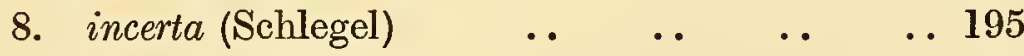

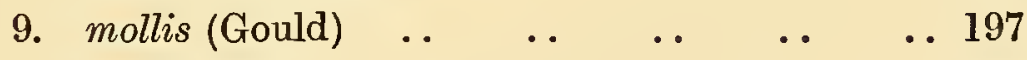

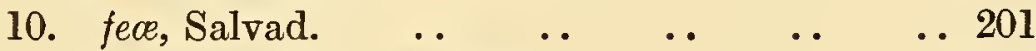

11. magentce, Gigl. and Salvad. . . .. .. 203

12. wortheni, Rothschild .. $\quad$.. $\quad$.. $\quad$.. 205

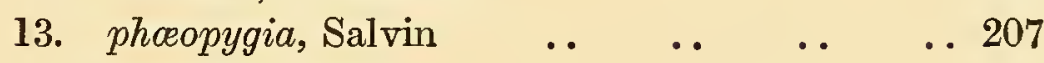

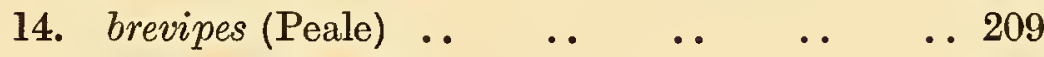

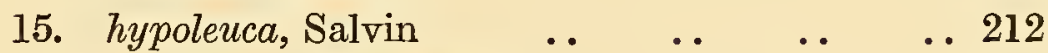

16. nigripennis, Rothschild $\quad$. $\quad \ldots \quad \ldots 214$

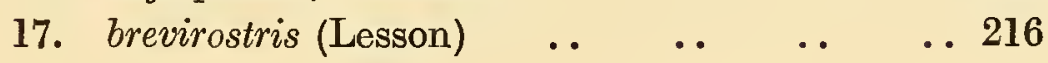




\section{MONOGRAPH OF THE PETRELS.}

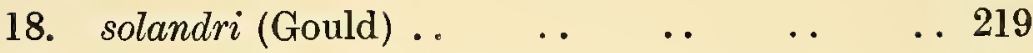

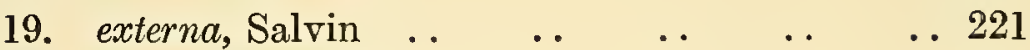

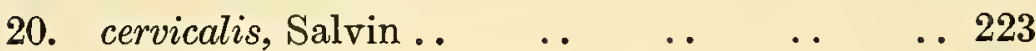

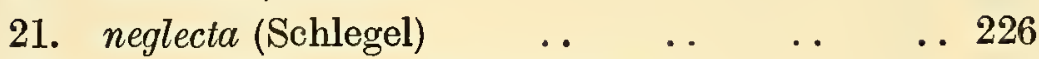

22. arminjoniana, Gigl. and Salvad. . . . . 229

23. trinitatis, Gigl. and Salvad. . . $\quad \ldots \quad \ldots 232$

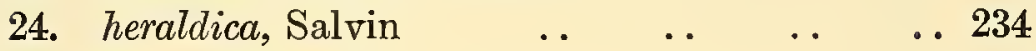

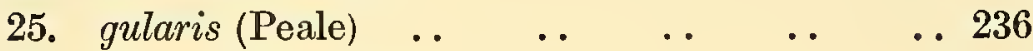

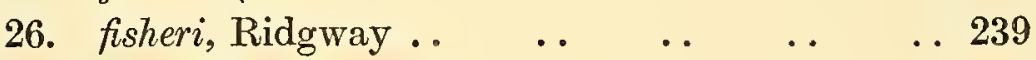

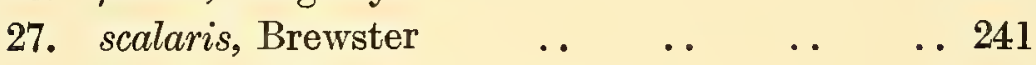

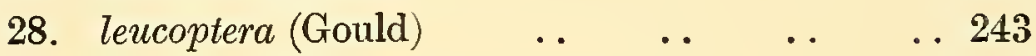

29. defilippiana, Gigl. and Salvad... $\quad \ldots \quad \ldots 245$

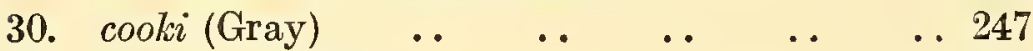

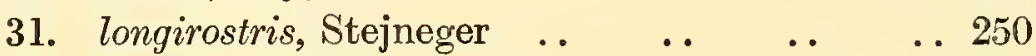

32. axillaris, Salvin .. $\quad \ldots \quad \ldots \quad \ldots \quad \ldots \quad$.. 252

15. Pagodroma, Bp.

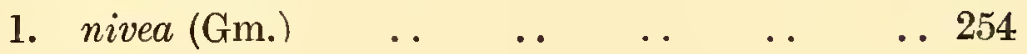

16. Bulweria, Bp.

1. bulweri (Jard. and Selby) _. $\quad$. $\quad$. 257

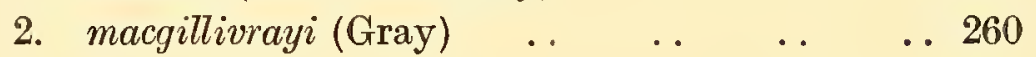

\section{SUB-FAMILY 2. FULMARIN}

17. Macronectes, Richmond.

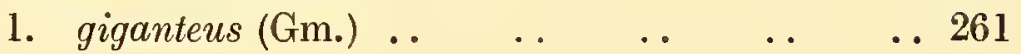

18. Fulmarus, Steph.

1. glacialis (Linn.) $\ldots$.

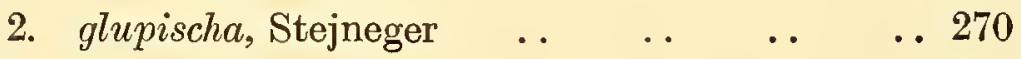

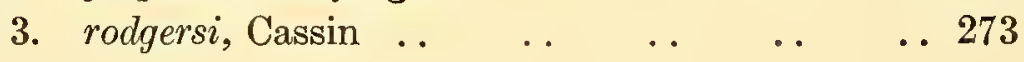

19. Daption, Steph.

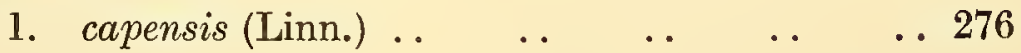

20. Halob 西na, Isid. Geoffr.

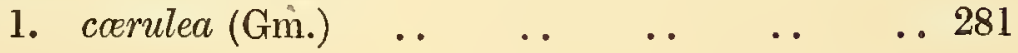




\section{SYSTEMATIC LIST OF SPECIES.}

21. Prion, Lacép.

1. vittatus (Gm.)

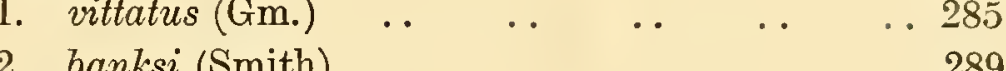

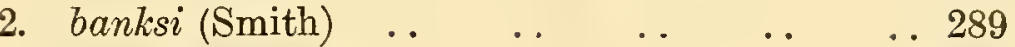

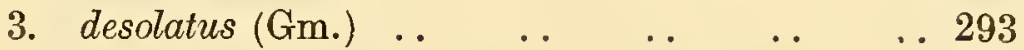

4. brevirostris, Gould (Prion ariel on Plate) .. 297

Family III. PELECANOIDIDA.

22. Pelecanoides, Lacép.

1. $\begin{array}{llllll}\text { urinatrix }(\mathrm{Gm} .) & \ldots & \ldots & \ldots & \ldots & \ldots\end{array}$

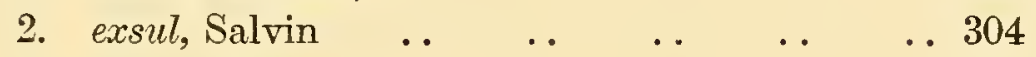

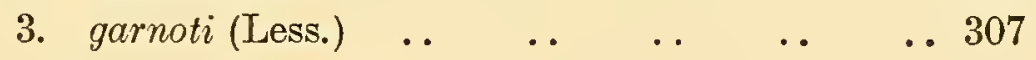

\section{Family IV. DIOMEDEIDÆ.}

23. Diomedea, Linn.

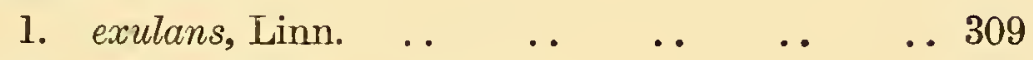

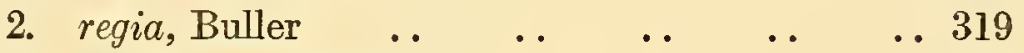

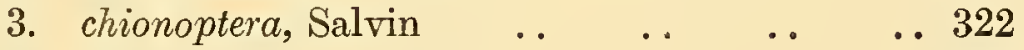

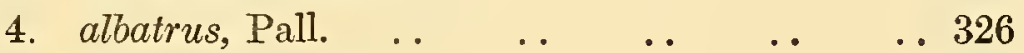

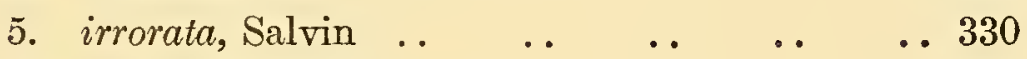

6. nigripes, Audub. .. $\quad \ldots \quad$. $\quad \ldots \quad$.. 332

7. immutabilis, Rothschild.. $\quad$.. $\quad \ldots \quad \ldots 336$

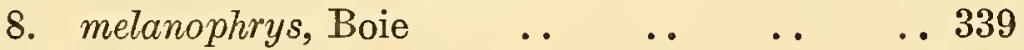

9. bulleri, Rothschild .. $\quad$. $\quad$. $\quad$. 344

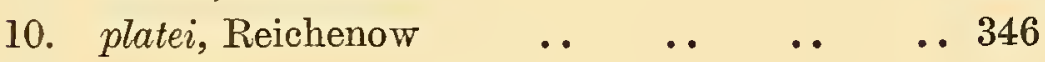

24. Thalassogeron, Ridgway.

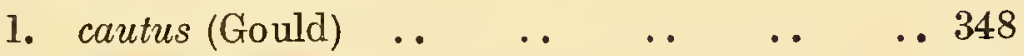

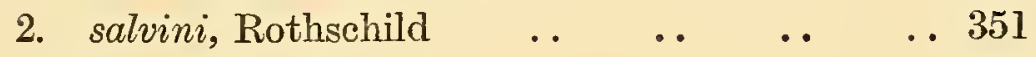

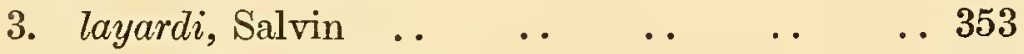

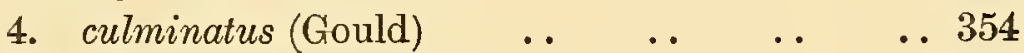

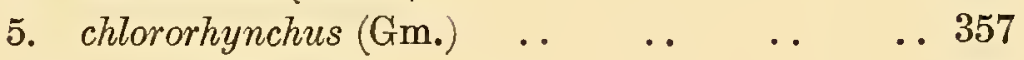

6. eximius, Verrill .. $\quad \ldots \quad \ldots \quad \ldots 60$

7. carteri, Rothschild _. $\quad$. $\quad \ldots \quad$.. 361

25. Phøвetria, Reichenb.

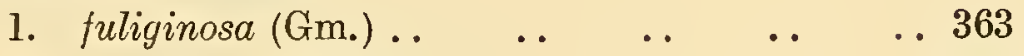

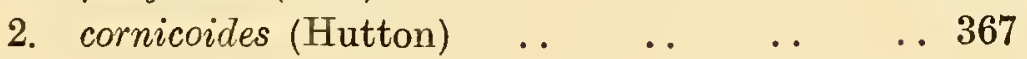




\section{,}




\section{LIST OF PLATES.}

1. Procellaria pelagica.

2.,$\quad$ tethys.

3. Halocyptena microsoma.

4. Oceanodroma leucorrhoa.

5.,$\quad$ castro (O. cryptoleucura, on Plate).

5a,$\quad$ macrodactyla.

6. , , melania.

7. , " markhami.

8.,$\quad$ homochroa.

$9 . \quad$ monorhis.

10. , hornbyi.

11. , furcata.

12. Oceanites oceanicus.

13. , gracilis.

14. Garrodia nereis.

15. Pelagodroma marina.

16. Pealea lineata.

17. Cymodroma melanogaster.

18. , grallaria.

$19 . \quad$ albigularis.

$20 . \quad$ mœstissima.

21. Puffinus leucomelas.

22. , cuneatus.

23. , bulleri.

24. ", chlororhynchus.

25.,$\quad$ gravis.

26. , kuhli.

27. , creatopus.

28.,$\quad$ anglorum.

29. „ yelkouanus.

30. , opisthomelas. 


\section{MONOGRAPH OF THE PETRELS.}

31. Puffinus auricularis.

32. ", gavia.

33.,$\quad$ persicus.

34.,$\quad$ obscurus.

35. , $\quad$ assimilis.

36.,$\quad$ elegans.

$37 . \quad, \quad$ carneipes.

38. ,,$\quad$ griseus.

39. ,,$\quad$ tenuirostris ( $P$. brevicauda on Plate)

40. ,, nativitatis.

41. Priofinus cinereus.

42. Thalassœea antarctica.

43. Priocella glacialoides.

44. Majaqueus æquinoctialis.

45. ",$\quad$ parkinsoni.

46. Estrelata macroptera.

47. , aterrima.

48. , , lessoni.

49. , hæsitata.

50. " $\quad$ jamaicensis.

51.,$\quad$ rostrata.

52.,$\quad$ parvirostris.

$53 . \quad, \quad$ incerta.

$54 . \quad, \quad$ mollis.

55. " magentæ.

$56 . \quad$, phæopygia.

$57 . \quad, \quad$ brevipes.

58. " " hypoleuca.

59 . , nigripennis.

$60 . \quad$, brevirostris.

61.,$\quad$ solandri.

62.,$\quad$ externa.

63. , , cervicalis.

64. , neglecta.

$65 . \quad, \quad$ arminjoniana.

$66 . \quad$ " trinitatis.

67., heraldica.

68. " gularis.

$69 . \quad$ ", leucoptera. 


\section{LIST OF PLATES.}

70. Estrelata defilippiana.

71. , cooki.

72.,$\quad$ axillaris.

73. Pagodroma nivea.

74. Bulweria bulweri.

75. " macgillivrayi.

76. Macronectes giganteus.

(Ossifraga gigantea, on Plate).

77. Fulmarus glacialis.

78. " glupischa.

79. , " rodgersi.

80. Daption capensis.

81. Halobæna cærulea.

82. Prion vittatus.

83. " banksi.

84. " desolatus.

85. " brevirostris (Prion ariel, on Plate)

86. Pelecanoides urinatrix.

$87 . \quad, \quad$ exsul.

88. , , garnoti.

89. Diomedea exulans.

$90 . \quad$ " regia.

91. " chionoptera.

$92 . \quad$, albatrus.

$93 . \quad$ " irrorata.

94. " nigripes.

95. , ", (young)

$96 . \quad$, immutabilis.

97. ", melanophrys.

$98 . \quad, \quad$ bulleri.

98a ,, platei.

99. Thalassogeron cautus.

$100 . \quad$, salvini.

101. ," culminatus.

$102 . \quad$., chlororhynchus.

102a " carteri.

103. Phœbetria fuliginosa. 



\section{CLASSIFICATION.}

Is his Introduction to the Tubinares in the "Catalogue of Birds in the British Museum," Salvin has passed in review the various attempts at classifying the Petrels. He enumerates the characters propounded by Fürbringer (1888), Seebohm (1890), Bowdler Sharpe (1891), and Gadow (1892). Of Forbes's work he writes as follows:- "The late William Alexander Forbes's Memoir, entitled 'Report on the Anatomy of the Petrels (Tubinares) collected during the voyage of H.M.S. 'Challenger' (see Report on the Scientific results of the Voyage of H.M.S. ' Challenger,' Zoology, Vol. IV., Part XI., 1882), gives by far the most complete account of the anatomy of this Order, discusses the relationship of a large number of species representative of many genera, gives a good résumé of the Literature of the subject, and the author's views as to the relationship of the Order to other Orders of the Class Aves." Salvin further observes:- "As the whole of the spirit-specimens possessed by me at the time were placed at Forbes's disposal and were used in compiling his Memoir, I have little to say on this branch of the subject beyond pointing out that I have ventured to depart to some extent from Forbes's classification in the present Catalogue. In doing so, I have to a great extent returned to the older plan of keeping the Albatroses distinct from the rest of the Petrels, and in restoring Forbes's Oceanitidce to the neighbourhood of the genus Procellaria. That such an arrangement is more convenient can hardly be doubted, and I think it can be justified."

In the "Catalogue of Birds" Salvin admitted four Families of the Tubinares, viz. :-
I. Procellariidæ.
II. Puffinidæ.
III. Pelecanoididæ.
IV. Diomedeidæ.

I have, in the present work, followed the classification of Salvin's "Catalogue," of 1896. Some of the "keys" to the genera and species have been modified and enlarged, according to the increase in our knowledge during the past twelve years. 


\title{
MONOGRAPH OF THE PETRELS.
}

\author{
FAMILY I.-PROCELLARID E. \\ (Salvin, Cat. Birds Brit. Mus., XXV., p. 343.) \\ Key to the Sub-families.
}

a. Leg-bones shorter than the wing-bones; tarsus never twice as long as the femur; basal phalanx of the middle toe shorter than the next two joints; keel of the sternum entirely ossified; tarsi covered in front with hexagonal scutes; claws sharp and compressed; outer toe shorter than the middle toe; secondaries, at least 13 inches ..

Procellariinoe

b. Leg-bones longer than the wing-bones; tarsus at least twice as long as the femur; basal phalanx of the middle toe as long as, or longer than, the next two joints; keel of sternum with a large fenestra; tarsi usually covered in front with a single shield, or with transverse short scutes; claws usually very flat; outer and middle toes sub-equal; secondaries, 10 inches $\quad \ldots \quad \ldots \quad \ldots \quad \ldots \quad$ Oceanitinoe

SUB-FAMILY I.-PROCELLARIINA.

(Salvin, Cat. Birds Brit. Mus., XXV., p. 343.)

Key to the Genera.

a. Tarsus longer than the middle toe and claw ; tail not distinctly forked.

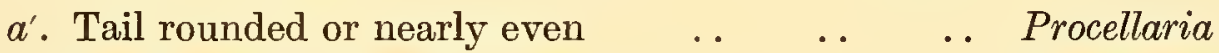

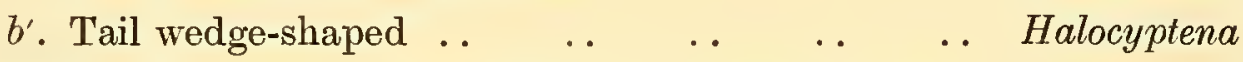

b. Tarsus not distinctly longer than the middle toe and claw; tail perceptibly forked . . . . . . Oceanodroma

\section{I.-Procellaria, Linn.}

Procellaria, Linn., Syst. Nat., I., p. 212 (1766) ; Salvin, Cat.

Birds Brit. Mus., XXV., p. $343(1896)$. . . . . . P. pelagica

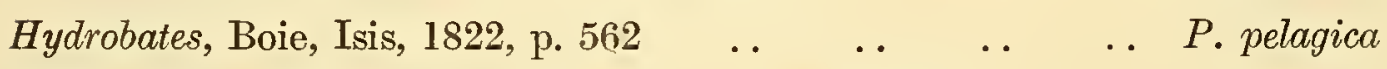

Thalassidroma, Vigors, Zool. Journ., ii., p. 405 (1825).. $\quad$.. P. pelagica 


\section{CLASSIFICATION.}

IT should be noted that the German ornithologists, following Professor Reichenow, adopt Boie's name Hydrobates, in preference to the Linnean name of Procellaria, the type of which is considered by them to be Procellaria aquinoctialis. Vide infra, pp. 169, 170.

\section{Key to the Species.}

a. Rump and upper tail-coverts white, the latter tipped with black; greater wing-coverts and innermost secondaries edged with white; under wing-coverts sooty-black, with the ends of the greater series white $\ldots \quad \ldots \quad \ldots \quad \ldots \quad \ldots \quad \ldots$ pelagica, $\mathrm{p} .1$

b. Rump and upper tail-coverts pure white, not tipped with black; greater wing-coverts ashybrown, margined with white; under wing-coverts sooty-black, without any white $\quad . \quad \ldots \quad \ldots \quad$.. tethys, p. 4

\section{II.-Halocyptena, Coues.}

Halocyptena, Coues, Pr. Acad. Nat. Sci. Philad., 1864, pp. 79,

90; Salvin, Cat. Birds Brit. Mus., XXV., p. 346 (1896) H. microsoma

ONe species, H. microsoma (p. 6), from the coasts of Western America.

\section{III.-Oceanodroma, Reichenb.}

Oceanodroma, Reichenbach, Syst. Av., p. iv. (1852);

Coues, Pr. Acad. Nat. Sci. Philad., 1864, p. 74 ;

Salvin, Cat. Birds Brit. Mus., XXV., p. 347 (1896). . O. furcata

Cymochorea, Coues, Pr. Acad. Nat. Sci. Philad., 1864, p. 75. . O. leucorrhoa

Key to the Species.

a. Plumage sooty-black, with more or less of an ashy shade; under-parts sooty.

$a^{\prime}$. Upper tail-coverts more or less white, not uniform with the back.

$a^{\prime \prime}$. Greater coverts ashy-brown, paler than the leucorrhoa, p. 8 rest of the wing; upper tail-coverts white, beali, p. 11 more or less ashy, sooty-brown, or blackish beldingi, p. 12 at the ends, or in the centres $\quad . . \quad \ldots \quad$ koedingi, p. 13 


\section{MONOGRAPH OF THE PETRELS.}

$b^{\prime \prime}$. Greater wing-coverts very slightly paler than the other coverts ; upper tail-coverts white, broadly tipped with black

$a^{\prime \prime \prime}$. Smaller; wing, 5.8-6.1 inches ; middle toe and claw, 0.9-0.95 inch .. $\quad . \quad$ castro, p. 15

$b^{\prime \prime \prime}$. Larger ; wing, 6.3-6.7 inches; middle toe and claw, 1.2-1.25 inch $\quad . \quad \ldots \quad$ macrodactyla, p. 18

$b^{\prime}$. Upper tail-coverts not white, but sooty-black like the back.

$c^{\prime \prime}$. Larger ; wing, 5.95-7.2 inches.

$c^{\prime \prime \prime}$. Plumage sooty-black, including the under wing-coverts.

$a^{4}$. Bill stout; culmen, 0.6 inch ; wing exceeding 6.75 inches $\quad \ldots \quad$ melania, p. 24

$b^{4}$. Bill slender; culmen, 0.7 inch; wing, 6.8-7.2 inches ..tristrami, p. 20 ; markhami, p. 27

$d^{\prime \prime \prime}$. Plumage more ashy; bill slender; culmen, 0.6 inch; wing, 5.7-6.2 inches in length . . . . . . . . .

$d^{\prime \prime}$. Smaller; wing, 5.1-5.65 inches; greater

under wing-coverts externally ashy $\quad$. homochroa, p. 29

monorhis, p. 32

b. Upper-parts grey; under-parts white, with a slatecoloured band across the fore-neck; crown $\begin{array}{llllllll}\text { blackish } & \ldots & \ldots & \ldots & \ldots & \ldots & \ldots & \text { hornbyi, } \\ & \text {. } 36\end{array}$

c. Upper- and under-parts entirely pale ashy-grey _. furcata, p. 38

SUB-FAMILY II.-OCEANITINE.

(Salvin, Cat. Birds Brit. Mus., XXV., p. 358.)

Key to the Genera.

a. Basal phalanx of the middle toe normal, or only slightly flattened, less than the remaining joints and claw.

$a^{\prime}$. Claws sharply spatulate, not much flattened.

$a^{\prime \prime}$. Scutellæ on the front of the tarsus obsolete Oceanites

$b^{\prime \prime}$. Scutellæ of the front of the tarsus distinct. . Garrodia 


\section{CLASSIFICATION.}

$b^{\prime}$. Claws flattened and wide.

$c^{\prime \prime}$. First primary much shorter than the third.. Pelagodroma

$d^{\prime \prime}$. First primary longer than the third .. Pealea

$b$. Basal phalanx of the middle toe much flattened and equal to or longer than the remaining joints and

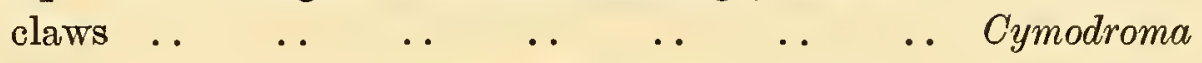

IV.-Oceanites, Keys. u. Blas.

Oceanites, Keyserling und Blasius, Wirb. Eur. II., pp. xciii., Type 131, 238 (1840) ; Coues, Pr. Acad. Nat. Sci. Philad., 1864, p. 82 ; Forbes, Voy. "Challenger," Zool., IV., pt. XI., p. 56 (1882) ; Salvin, Cat. Birds Brit. Mus.,

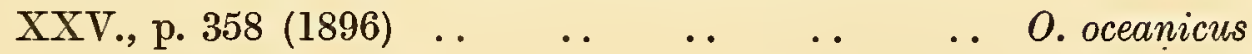

Key to the Species.

a. Larger ; abdomen sooty-brown.. . . . . $\quad \ldots$ oceanicus, p. 41

b. Smaller; abdomen white.. $\quad \ldots \quad \ldots \quad \ldots \quad \ldots \quad \ldots$ gracilis, p. 48

$$
\text { V.-Garrodia, Forbes. }
$$

Garrodia, Forbes, P.Z.S., 1881, p. 735 ; id., Voy. "Challenger,"

Type

Zool., IV., pt. XI., p. 56 (1882) ; Salvin, Cat. Birds

Brit. Mus., XXV., p. 361 (1896) . $\quad$. . $\quad$.. G. nereis

ONe species, Garrodia nereis (p. 50), from the Southern Oceans.

\section{VI.-Pelagodroma, Reichenb.}

Pelagodroma, Reichenbach, Syst. Av., p. iv. (1852);

Coues, Pr. Acad. Nat. Sci. Philad., 1864, p. 87 ;

Forbes, Voy. "Challenger," Zool., IV., pt. XI.,

p. 56 (1882) ; Salvin, Cat. Birds Brit. Mus.,

XXV., p. 362 (1896) . $\quad$. . $\quad$.. $\quad$.. $\quad$.. $\quad$ P. marina

ONE species, Pelagodroma marina (p. 53), ranging from the Atlantic Ocean (Canary

Islands and Madeira to E. North America) and south to the Australian Seas.

$$
\text { VII.-Pealea, Ridgway. }
$$

Pealea, Ridgway, Auk, III., p. 334 (1886) ; id., Manual N.

Amer. Birds, p. 56 (1887) ; Salvin, Cat. Birds

Brit. Mus., XXV., p. $364(1896) \quad$. $\quad \ldots \quad$.. $\quad$ P. lineata

A single species, Pealea lineata (p. 57), from the Pacific Ocean. 


\section{MONOGRAPH OF THE PETRELS.}

VIII.-Cymodroma, Ridgway.

Fregetta*, Bp., Comptes Rendus, XLI., p. 1113 (1855);

Type

id., Consp. Av. II., p. 197 (1856, nec, Brisson

et auct.); Coues, Proc. Acad. Nat. Sci. Philad.,

1864, p. 85 ; Forbes, Voy. "Challenger," Zool., IV.,

pt. XI., p. 56 (1882)

Cymodroma, Ridgway in Baird, Brewer, and Ridgway, Water

Birds N. Amer., II., p. 418 (1884); id., Man.

N. Amer. Birds, p. 71 (1887); Salvin, Cat. Birds

Brit. Mus., XXV., p. 364 (1896) _. $\quad$.. $\quad \ldots \quad$ C. grallaria

Key to the Species.

a. Breast and abdomen white, the middle of the latter sooty-black; throat and fore-neck sooty .. . . . melanogaster, p. 59

b. Breast and abdomen entirely white.

$a^{\prime}$. Throat mottled with white, or almost entirely white; upper-surface uniform, without white

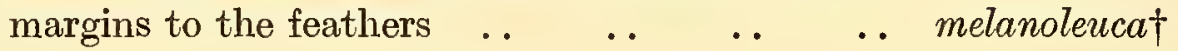

$b^{\prime}$. Throat uniform sooty-black; upper-surface regularly barred with greyish-white edges to

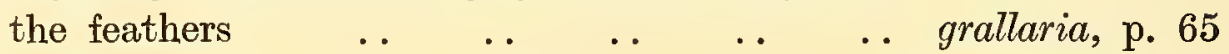

$c^{\prime}$. Throat white, like the rest of the under-surface; a broad brown pectoral band $\quad \ldots \quad \ldots \quad \ldots \quad \ldots$ albigularis, $\mathrm{p}, 68$

c. Under-surface entirely sooty-brown $\quad . \quad \ldots \quad \ldots \quad \ldots$ mostissima, p. 71

\section{FAMILY II.-PUFFINIDA.}

(Salvin, Cat. Birds Brit. Mus., XXV., p. 368.)

Key to the Sub-families.

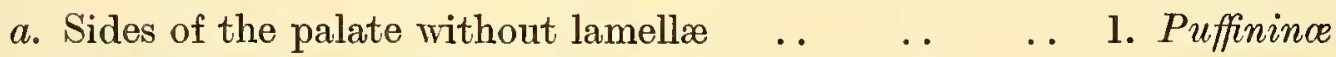

b. Sides of the palate with more or less distinctly

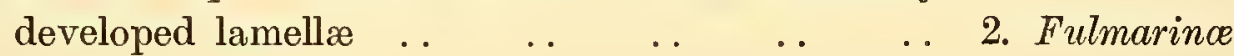

* Count Salvadori (Bull. Brit. Orn. Club, XXI., p. 79, 1908) employs the generic name of Fregetta, instead of Cymodroma, as he does not agree that Fregetta and Fregata are synonymous.

$\dagger$ Since the enumeration of the species of the genus Cymodroma was published Count Salvadori has separated this form from $C$. grallaria, Vieill., under the name $C$. (Fregetta) melanoleuca [Bull. Brit. Orn. Club, XXI., pp. 78, 79 (1908)]. It is based upon a specimen (now in the Turin Museum) purchased at Bullock's sale in 1819, and is said to be from the Island of Tristan da Cunha. 


\section{CLASSIFICATION.}

SUB-FAMILY I.-PUFFININÆ.

(Salvin, Cat. Birds Brit. Mus., XXV., p. 368.)

Key to the Genera.

a. Tarsi distinctly compressed, the anterior edge sharp.

$a^{\prime}$. Nasal tube flat; both apertures visible from above, directed forwards and slightly upwards ;

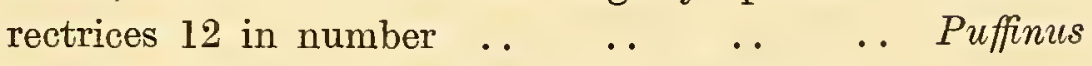

$b^{\prime}$. Nasal tube raised; apertures not visible from $\begin{array}{llllllll}\text { above } & \text {. } & \ldots & \ldots & \text {. } & \text {. } & \text {.. } & \text { Priofinus }\end{array}$

$c^{\prime}$. Nasal tube higher; nostrils united into a single opening directed forwards.

$a^{\prime \prime}$. Rectrices 12 in number . . . . . . Thalassoca

$b^{\prime \prime}$. Rectrices 14 in number . $\quad \ldots \quad \ldots$ Priocella

b. Tarsi not compressed, more rounded on the anterior edge; rectrices 12 in number.

$d^{\prime}$. Tail moderate in length, rounded.

$c^{\prime \prime}$. Bill long, stout, mostly yellow in colour; unguis large; nasal tube directed forwards; claw of hallux small . . $\quad \ldots \quad$. $\quad$. $\quad \ldots$ Majaqueus

$d^{\prime \prime}$. Bill shorter, stouter, black; unguis large; nasal opening directed more or less slightly upwards; claw of hallux small . . . . Estrelata

$e^{\prime \prime}$. Bill slender, black; nasal tube high; unguis slender; claw of hallux large .. Pagodroma

$e^{\prime}$. Tail long, wedge-shaped; nasal tubes fleshy at the ends, the openings separate and directed forwards and upwards $\quad . \quad$.

IX.-Puffinus, Brisson.

Puffinus, Brisson, Orn., VI., p. 131 (1760); Coues, Pr.

Acad. Nat. Sci. Philad., 1864, p. 127, 1866, p. 192 ;

Ridgway, Man. N. Amer. Birds, p. 58 (1887);

Salvin, Cat. Birds Brit. Mus., XXV., p. 368 (1896) .. P. puffinus*

* In his synonymy of the genus Puffinus, Salvin gives the type of Brisson's genus as Puffinus puffinus, which is the name now generally employed. In the body of the 'Catalogue,' however, he calls the typical species Puffinus anglorum, and does not use the duplicated specific and generic name. 


\section{MONOGRAPH OF THE PETRELS.}

Nectris, Kuhl, Beitr., p. 144 ; Coues, Pr. Acad. Nat. Sci. Philad., 1864, p. 123.

Thyellas, Gloger, in Froriep's Notizen, XVI., p. 279 (1827); Salvin, Ibis, 1888, p. 353.

Thiellus, Gray, List Gen. Birds, 1840, p. 78 ; Bp., Consp. Av., II., p. 200 (1856) ; Coues, Pr. Acad. Nat. Sci.

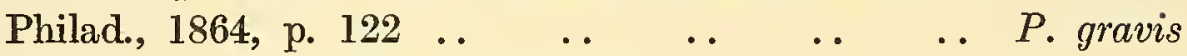

Cymotomus, Macgill., Man. Brit. Birds, p. 13 (1842) ․ P. anglorum

Ardenna, Reichenbach, Syst. Av., p. iv. (1852) .. .. Thyellodroma, Stejneger, Pr. U.S. Nat. Mus., XI., p. 93 $\begin{array}{lllllllll}(1888) & \ldots & \ldots & \ldots & \ldots & \ldots & \ldots & \ldots\end{array}$ Zalias, Heine, Nomencl. Mus. Hein., p. 362 (1890, vice

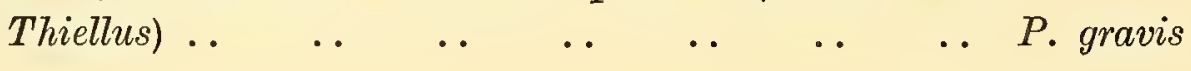

Key to the Species.

a. Tail long, wedge-shaped.

$a^{\prime}$. Under-surface white; feathers of the head, sides of neck, and upper plumage generally sootybrown, conspicuously edged with white ..

$b^{\prime}$. Under-surface white; feathers of the head and upper plumage not edged with white

$a^{\prime \prime}$. Back, greater coverts and primaries entirely $\begin{array}{lllllll}\text { sooty-brown } & \ldots & \ldots & \ldots & \ldots & \ldots & \text { cuneatus, } \\ \text { p. } 76\end{array}$

$b^{\prime \prime}$. Back and greater coverts grey; inner half of inner web of primaries white . . . $\quad$ bulleri, p. 81

$c^{\prime}$. Under-surface sooty-brown, like the uppersurface $\quad . \quad \ldots$ chlororhynchus, p. 84 ; cuneatus (dark phase), p. 76

b. Tail shorter, rounded, sometimes slightly wedgeshaped

$d^{\prime}$. Under-surface white.*

$c^{\prime \prime}$. Larger; wing 12 inches and upwards.

$a^{\prime \prime \prime}$. Back and upper tail-coverts inconspicuously edged with pale duskybrown ; crown darker than the hinderneck.

* Sometimes mottled with ashy-brown ( $P$. gravis; $P$. yelkouanus). 


\section{CLASSIFICATION.}

$a^{4}$. White area on sides of neck clearly defined; flanks spotted with brown; middle of abdomen spotted with light brown .. . . gravis, p. 90

$b^{4}$. Sides of neck mottled; axillaries pure white; flanks and middle of abdomen pure white.

$a^{5}$. Larger; wing 13.3 inches .. kuhli, p. 94

$b^{5}$. Smaller; wing 11.95 inches .. edwardsi, p. 99

$b^{\prime \prime \prime}$. Upper-surface nearly uniform; sides of head mottled; under tail-coverts smoky-brown $\quad$. $\quad \ldots \quad \ldots \quad \ldots \quad$. $\quad$ creatopus, p. 101

$d^{\prime \prime}$. Smaller; wing not exceeding 9.0 inches.

$c^{\prime \prime \prime}$. Axillaries white, with blackish or dusky tips.

$c^{4}$. Under tail-coverts white; flanks white.. $\quad . . \quad \ldots \quad \ldots \quad \ldots$ anglorum, p. 104

$d^{4}$. Under tail-coverts and flanks dusky$\begin{array}{lllllll}\text { brown } & \ldots & \ldots & \ldots & \ldots & \text { yelkouanus, p. } 107\end{array}$

$e^{4}$. Under tail-coverts and flanks blackish ; sides of throat and foreneck mottled with ashy-brown bars .. $\quad \ldots \quad$. . $\quad \ldots \quad$.. opisthomelas, p. 109

$d^{\prime \prime \prime}$. Axillaries entirely white, or with occasional dusky mottlings.

$f^{4}$. Under tail-coverts sooty-black.

$c^{5}$. Axillaries white, or white with dusky sub-terminal spots and blackish shaft-lines _. auricularis, p. 112 ; newelli, p. 115

$d^{5}$. Axillaries dusky-brown, or white, with a certain amount of sooty-brown mottling _. subalaris, p. 117

$g^{4}$. Under tail-coverts white, with the lateral ones occasionally marked. with sooty-brown.

$e^{5}$. Axillaries dusky-brown. 
MONOGRAPH OF THE PETRELS.

$a^{6}$. Under tail-coverts white. . gavia, p. 120

$b^{6}$. Under tail-coverts white, but the lateral ones sootybrown .. $\quad$. $\quad$.. persicus, p. 124

$f^{5}$. Axillaries white, or white with a little brown or ashy mottling.

$c^{6}$. Quills dusky-brown below, not white or ashy-white.

$a^{7}$. Above black . . . obscurus, p. 126

$b^{7}$. Above brown $\quad$. auduboni, p. 129

$d^{6}$. Quills white or hoarywhite below

$c^{7}$. Under tail-coverts pure white assimilis, p. 133 ; elegans, p. 136

$d^{7}$. Under tail-coverts

white, the lateral ones more or less distinctly edged with black $\quad$. $\quad$. $\quad$ bailloni, p. 138

$e^{\prime}$. Under-surface sooty-brown like the upper-surface.

$e^{\prime \prime}$. Under wing-coverts sooty-brown, or slightly ashy, but not white. . . . tenuirostris, p. 149

$f^{\prime \prime}$. Under wing-coverts more or less white, with black shaft-stripes or cross-bars.

$e^{\prime \prime \prime}$. Under-surface sooty-brown; throat grey $\quad \ldots \quad \ldots \quad \ldots \quad \ldots$ griseus, p. 145

$f^{\prime \prime \prime}$. Under-surface whitish, with crossbars of ashy-grey $\quad$. creatopus (dark phase), p. 101

$g^{\prime \prime}$. Under wing-coverts sooty-black.

$g^{\prime \prime \prime}$. Larger ; wing, 12 inches, or more ; bill and feet flesh-coloured, the tip of the bill black . . . . carneipes, p. 142

$h^{\prime \prime \prime}$. Smaller; wing, not exceeding 10 inches; bill and feet black .. nativitatis, p. 153 


\section{CLASSIFICATION.}

X.-Priofinus, Hombr. et Jacq.

Priofinus, Hombr. et Jacq., Comptes Rendus, XVIII.,

Type

p. 355 (1844); Jacq. et Pucheran, Voy. Pôle Sud,

Zool., III., p. 145, Pl. 32, Figs. 9-14 (1853) ; Coues,

Pr. Acad. Nat. Sci. Philad., 1866, p. 192 ; Salvin,

Cat. Birds Brit. Mus., XXV., p. 390 (1896) .

Adamastor, Bp., Consp. Av., II., p. 187 (1855) ; Coues,

Pr. Acad. Nat. Sci. Philad., 1864, p. $119 \quad$.. $\quad$.. $\quad$ P. cinereus

THE genus Priofinus is represented by a single species, $P$. cinereus (p. 155), an inhabitant of the Southern Oceans.

\section{XI.-Thalassceca, Reichenb.}

Thalassaca, Reichenbach, Syst. Av., p. iv. (1852) ; Coues, Pr.

Acad. Nat. Sci. Philad., 1866, p. 29 ; Salvin, Cat.

Birds Brit. Mus., XXV., p. 392 (1896) _. $\quad$.. $\quad$ T. antarctica

Acipetes, Forbes, Voy. "Challenger," Zool., IV., pt. XI.,

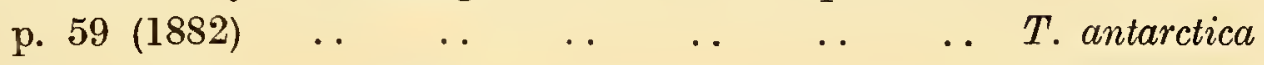

REPRESENTED by a single species, Thalasscea antarctica (p. 161), peculiar to the Antarctic Ocean.

$$
\text { XII.-Priocella, Hombr. et Jacq. }
$$

Priocella, Hombr. et Jacq., Compt. Rend. XVIII., p. 357

\section{Type}

(1844); Jacq. et Pucheran, Voy. Pôle Sud,

Zool., III., p. 148, Pl. 32, Figs. 43, 56 (1853);

Salvin, Cat. Birds Brit. Mus., XXV., p. 393 (1896) P. glacialoides

Thalassceca, pt., Coues, Pr. Acad. Nat. Sci. Philad., 1866, p. 29.

A SINGLE species, P. glacialoides (p. 165), inhabiting the Southern Oceans.

$$
\text { XIII.-MaJaqueus, Reichenb. }
$$

Majaqueus, Reichenbach, Syst. Av., p. iv. (1852) ; Coues, Pr.

Type

Acad. Nat. Sci. Philad., p. 117 ; Salvin, Cat. Birds

Brit. Mus., XXV., p. 395 (1896) _. $\quad$. $\quad$. $\quad$ M. cequinoctialis

Cymatobulus, Heine, Nomencl. Mus. Hein., p. 363 (1890) . M. Mquinoctialis

Key to the Species.

a. Larger; chin and sides of face with a varying amount of white 


\section{MONOGRAPH OF THE PETRELS.}

b. Smaller ; no white on chin or sides of face, which are sooty-black like the rest of the under-surface $\quad . \quad$ parkinsoni, p. 174

$$
\text { XIV.-Cestrelata, Bp. }
$$

AEstrelata, Bp., Consp. Av., II., p. 188 (1855); Coues, Pr. Acad.

Nat. Sci. Philad., 1866, p. $137 \quad$. $\quad \ldots \quad \ldots$ E. hositata

Cookilaria, Bp., Consp. Av., II., p. 190 (1855) . . . . $\quad$. $\quad$ E. leucoptera

Pterodroma, Bp., Consp. Av., II., p. 191 (1855) .. $\quad$. $\quad$ E. macroptera

Éstrelata (nom. emend.), Newton, Ibis, 1870, p. 277 ; Forbes, Voy. "Challenger," Zool., IV., pt. XI., p. 39 (1882); Salvin, Cat. Birds Brit. Mus., XXV., p. 397 (1896).

\section{Key to the Species.}

a. Long under tail-coverts white.

$a^{\prime}$. Head white; hind-neck grey like the back; a conspicuous black mask in front of and below the eye $\quad$.

lessoni, p. 181

$b^{\prime}$. Head black, followed by a white collar, the feathers of which have often dusky tips.

$a^{\prime \prime}$. Upper tail-coverts white; upper-surface brown, the marginal under wing-coverts black, forming a broad band _. $\quad \ldots$ hoesitata, p. 184

$b^{\prime \prime}$. Upper tail-coverts blackish or slaty-grey; back bluish-grey; the black band on the inarginal under wing-coverts narrow and interrupted, or practically obsolete.

$a^{3}$. Marginal coverts of the wing below, black, forming a band round the edge of the wing; primaries grey below, white only at the base .. $\quad . \quad \ldots \quad$ cervicalis, p. 223

$b^{3}$. Margin of the wing below white; primaries below conspicuously white towards the base $\quad \ldots \quad \ldots \quad \ldots$ externa, $p$.

$c^{\prime}$. Head grey or blackish like the back; or head black, contrasting with the back, but without white collar round the neck. 


\section{CLASSIFICATION.}

$c^{\prime \prime}$. Breast and abdomen not white, but ashygrey; throat white.

c. ${ }^{3}$ Larger ; wing, 9.9-10.15 inches ; greater part of inner web of primaries white .. gularis, p. 236; fisheri, p. 239 ; scalaris, p. 241

$d{ }^{3}$ Smaller; wing, under 9 inches; inner web of primaries ashy-brown, not white

$d^{\prime \prime}$. Breast and abdomen white.

brevipes (dark phase),

$e^{3}$. Under wing-coverts for the most part white, excepting for a more or less broad marginal border of black or slaty-grey.

$a^{4}$. Inner webs of primaries conspicuously white.

$a^{5}$. Axillaries white.

$a^{6}$. Head black, contrasting with the grey back

$a^{7}$. Black extending down the neck on to the sides of the breast; a distinct marginal band of black on the under wing-coverts leucoptera, p. 243

$b^{7}$. Sides of neck and upper breast grey; the black band round the margin of the wing below narrow and interrupted .. longirostris, p. 250

$b^{6}$. Head grey like the back

$c^{7}$. General colour darker; bill longer and more slender cooki, p. 247

$d$. General colour paler; bill shorter and stouter .. .. defilippiana, p. 245 


\section{MONOGRAPH OF THE PETRELS.}

$b^{5}$. Axillaries black $\quad \ldots \quad \ldots$ axillaris, p. 252

$b^{4}$. Inner webs of primaries greyish brown, not white $\quad \ldots \quad \ldots \quad \ldots$ nigripennis, p. 214

$f^{3}$. Under wing-coverts entirely black or slaty-grey with a median patch of white or grey.

$c^{4}$. Smaller ; wing, 8.5-8.8 inches.

$c^{5}$. No grey frecklings on the under-surface, the latter entirely white.. .. . . hypoleuca, p. 212

$d^{5}$. Breast and sides of body freckled with grey .. $\quad$.. brevipes (light phase), p. 209

$d^{4}$. Larger ; wing, 11.6-12.0 inches.

$e^{5}$. Above blackish, with white edgings to the feathers; head intensely black; forehcad white with black spots _. phooopygia, p. 207

$f^{5}$. Above grey; forehead hoary white.

$c^{6}$. Underneath white, with more or less of a grey collar on the fore-neck . mollis, p. 197

$d^{6}$. Underneath entirely white, with no grey collar on the fore-neck.. $\quad$. $\quad$. . fece, p. 201

$g^{6}$. Above blackish; chin and upper-throat white; lower-throat and foreneck black or slatygrey .. magentce, p. 203 ; wortheni, p. 205

$h^{6}$. Above black ; entire throat black, slightly mottled with white .. rostrata, p. 190 ; parvirostris, p. 193

b. Long under tail-coverts dusky-brown, or blackish.

$d^{\prime}$. Under-surface white.

$e^{\prime \prime}$. Quills uniform below, with no white on the inner webs of the primaries; throat and sides of neck ashy-brown, a little paler than the crown 


\section{CLASSIFICATION.}

$f^{\prime \prime}$. Quill-lining white towards the base of the inner web of the primaries.

$g^{3}$. Head whitish; sides of face and neck white like the under-surface of the body; long primaries with white shafts _. $\quad \ldots \quad \ldots \quad \quad \ldots \quad$ neglecta (light phase), p. 226

$h^{3}$. Head dark brown; sides of face and neck also dark brown; long primaries with brown shafts.

$e^{4}$. Lores pure white .. $\quad . . \quad \ldots$ heraldica, p. 234

$f^{4}$. Lores spotted with black arminjoniana (light phase), p. 229

$e^{\prime}$. Under-surface sooty-black or grey.

$g^{\prime \prime}$. Upper tail-coverts white $\quad \ldots \quad \ldots \quad \ldots$ jamaicensis, p. 187

$h^{\prime \prime}$. Upper tail-coverts coloured like the back.

$i^{3}$. White base of inner web of primaries more or less well marked.

$g^{4}$. Shafts of outer primaries white ..

neglecta (dark phase), p. 226

$h^{4}$. Shafts of outer primaries black or brown.

$g^{5}$. Larger; wing, 11.8 inches; upper surface grey, with blackish margins to the feathers ; tarsi and feet black $\quad . \quad$.. solandri, p. 219

$h^{5}$. Smaller; wing, 10.7 inches; upper-surface sooty-brown, tarsi and base of toes fleshcolour .. $\quad$. $\quad \ldots \quad$. .

$j^{3}$. No white base to the inner webs of the primaries.

$i^{4}$. General colour slaty-grey; axillaries also slaty-grey, like the breast .. brevirostris, p. 216

$j^{4}$. General colour blackish or sootybrown.

$i^{5}$. Bill and feet larger; culmen

1.45 inches .. $\quad . . \quad \ldots$ macroptera, p. 176 


\section{MONOGRAPH OF THE PETRELS.}

$j^{5}$. Bill and feet smaller; culmen,

1.15-1.25 inches.

$i^{6}$ Tarsi and feet black .. trinitatis, p. 232

$j^{6}$ Tarsi and feet yellowish, toes black _. . . aterrima, p. 179

XV.-Pagodroma, Bp.

Pagodroma, Bp., Consp. Av., II., p. 192 (1855); Coues, Pr.

Type

Acad. Nat. Sci. Philad., 1866, p. 159 ; Salvin, Cat.

Birds Brit. Mus. XXV., p. 419 (1896) _. .. P. nivea

A sInale Antarctic species, $P$. nivea (p. 254).

XVI.-Bulweria, Bp.

Bulweria, Bp., Cat. Met. Ucc. Europ., p. 81 (1842) ; id., Type

Consp. Av., II., p. 194 (1856); Forbes, Voy.

"Challenger," Zool., IV., pt. XI., p. 38 (1882);

Salvin, Cat. Birds Brit. Mus., XXV., p. 420 (1896) B. bulweri

Asstrelata, pt., Coues, Pr. Acad. Nat. Sci. Philad., 1866, p. 158.

Key to the Species.

a. Bill more slender; greater wing-coverts lighter and greyer than the other coverts and the back; chin greyer than the rest of the under-surface ; middle toe and claw, 1.3 inch $\quad \ldots \quad \ldots \quad \ldots \quad \ldots$ bulweri, p. 257

b. Bill stouter; greater wing-coverts sooty-brown like the others; chin like the rest of the undersurface ; middle toe and claw, 1.6 inch ... . . macgillivrayi, p. 260

SUB-FAMILY II.-FULMARINA.

(Salvin, Cat. Birds Brit. Mus., XXV., p. 422.)

Key to the Genera.

a. Size very large ; total length, about 35 inches ; nasal tube very long and stout; inter-ramal space feathered throughout; tail-feathers 16 in number Macronectes, p. 261

6. Size smaller; total length, about 18.5 inches; inter ramal space bare; tail-feathers 14 in number. 


\section{CLASSIFICATION.}

$a^{\prime}$. Bill stout, the rami of the mandible strong; nasal tube large and high at the base, equal to the width of the latericorn ; tarsi stout. . . .

Fulmarus, p. 265

$b^{\prime}$. Bill more slender; rami of mandible weak; nasal tube smaller, narrower, and lower at the base, less than the width of the latericorn; tarsi $\begin{array}{llllllll}\text { slender } & \ldots & \ldots & \ldots & \ldots & \ldots & \ldots & \text { Daption, p. } 276\end{array}$

c. Smallest; nasal tube short; rectrices 12 in number.

$c^{\prime}$. Lamellæ on the sides of the palate rudimentary; first and second primaries sub-equal ; tail tipped with white. . $\quad$. $\quad \ldots \quad$. . $\quad \ldots \quad \ldots$

$d^{\prime}$. Lamellæ on the sides of the palate more or less well-developed; first primary longest ; tail tipped with black.

\section{Prion, p. 285}

XVII.-Macronectes, Richmond.

Ossifraga, Hombr. et Jacq., Comptes Rendus, XVIII., p. Type 356 (1844) (nec Wood); Bp., Consp. Av., II., p. 186 (1855) ; Coues, Pr. Acad. Nat. Sci. Philad., 1866, p. 31 ; Forbes, Voy. " Challenger," Zool., IV., pt. XI., p. 42 (1882); Salvin, Cat. Birds Brit. Mus., XXV.,

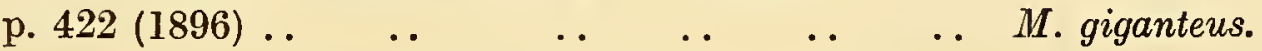

Macronectes, nom. emend., Richmond, Pr. Biol. Soc. Washington, XVIII., p. 76 (1906).

A SINGLe species, $M$. giganteus (p. 261), confined to the Southern Oceans.

\section{XVIII.-Fuximarus, Steph.}

Fulmarus, Steph. in Shaw's Gen. Zool., XIII., p. 233 (1826) ;

Type

Bp., Consp. Av., II., p. 186 (1855) ; Coues, Pr.

Acad. Nat. Sci. Philad., 1866, p. 28 ; Forbes, Voy.

"Challenger," Zool., IV., pt. XI., p. 42 (1882);

Salvin, Cat. Birds Brit. Mus., XXV., p. 424 (1896).. F. glacialis

Rhantistes, Kaup, Natürl. Syst., p. 105 (1829).

Wagellus, Gray, List Gen. Birds, p. 78 (1840).

\section{Key to the Species.}

a. Nasal tubes dark .. $\quad \ldots \quad \ldots \quad \ldots$. . $\quad \ldots \quad$.

b. Nasal tubes yellow. 


\section{MONOGRAPH OF THE PETRELS.}

$a^{\prime}$. Upper surface almost uniformly dark from the back to the tail. . $\quad . . \quad \ldots \quad$. . glupischa (dark phase),

$b^{\prime}$. Upper surface light bluish-grey, under surface $\begin{array}{lllllll}\text { white } & \ldots & \ldots & \ldots & \ldots & \ldots & \text { glupischa (light phase), }\end{array}$

$c^{\prime}$. Upper surface bluish-grey with a greater or less admixture of white $\quad . \quad \ldots \quad \ldots$ rodgersi, p. 273

XIX.-Daption, Steph.

Daption, Steph. in Shaw's Gen. Zool., XIII., p. 239 (1826); Type Bp., Consp. Av., II., p. 188 (1855); Coues, Pr. Acad. Nat. Sci. Philad., 1866, p. 162 ; Forbes, Voy. "Challenger," Zool., IV., pt. XI., p. 42 (1882); Shufeldt, Pr. U.S. Nat. Mus., VII., p. 378 (1887); Salvin, Cat. Birds Brit. Mus., XXV., p. 428 (1896)

D. capensis

A sinale species, Daption capensis (p. 276), found in all the Southern Oceans.

XX.-HALOB ÆeNA, Isid. Geoffr.

Halobcena, Isid. Geoffr. St. Hilaire, 1830, fide Bp., Consp. Type Av., II., p. 193 (1856) ; Coues, Pr. Acad. Nat. Sci. Philad., 1866, p. 162; Salvin, Cat. Birds Brit. Mus.,

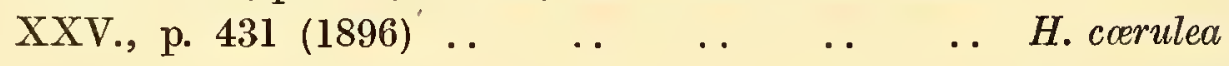

Zaprium, Coues, Bull. U.S. Nat. Mus., No. 2, p. 34 (1875) . . H. coerulea

One species, H. coerulea (p. 281), from the Southern Oceans.

XXI.-Prion, Lacép.

Prion, Lacépède, Mém. l'Instit., III., p. 513 (1801); Bp., Type Consp. Av., II., p. 192 (1856) ; Coues, Pr. Acad. Nat. Sci. Philad., 1886, p. 167 ; Forbes, Voy. "Challenger," Zool., IV., pt. XI., p. 42 (1882); Salvin, Cat. Birds Brit. Mus., XXV., p. 432 (1896).. P. vittatus Pachyptila, Illiger, Prodr., p. 274 (1811) _. $\quad \ldots \quad$. . $\quad$ P. vittatus Priamphus, Rafinesque, Anal., p. 72 (1815) .. . . . . Pseudoprion, Coues, Pr. Acad. Nat. Sci. Philad., 1866, p. 164 P. desolatus 


\section{CLASSIFICATION.}

Key to the Species.

a. Bill very broad, and bowed inwards towards the tip; the lamellæ on the side of the upper mandible distinctly visible when the bill is closed .. $\quad . \quad$ vittatus, p. 285

b. Bill narrower, distinctly bowed inwards towards the tip; lamellæ much less distinct, and only visible in the closed bill towards the gape. . . . . .

c. Bill still narrower, not bowed inwards towards the tip, the sides nearly straight; lamellæ much reduced in size, and not visible when the bill is

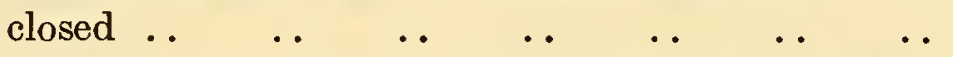

d. Bill shorter, stouter, and much compressed, not bowed inwards towards the tip, but with the sides nearly

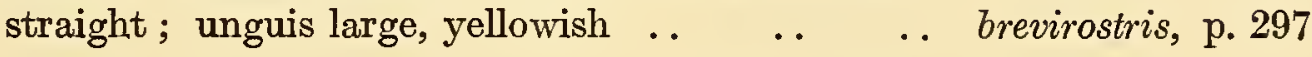

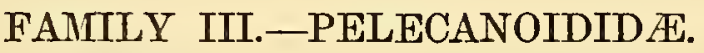

(Salvin, Cat. Birds Brit. Mus., XXV., p. 437.)

\section{XXII.-PeLecanotdes, Lacép.}

Pelecanoides, Lacépède, Mém. l'Instit., III., p. 513 (1801);

Type

Coues, Pr. Acad. Nat. Sci. Philad., 1866, p. 188 ;

Forbes, Voy. "Challenger," Zool., IV., pt. XI., p. 42 (1882); Shufeldt, Pr. U.S. Nat. Mus., X., p. 380 (1887); Salvin, Cat. Birds Brit. Mus.,

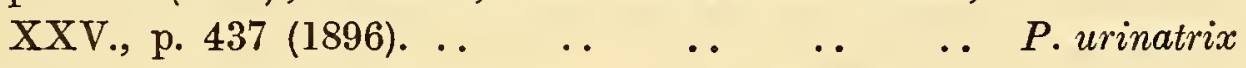

Haladroma, Tliger, Prodr., p. 273 (1811) ; Bp., Consp. Av.,

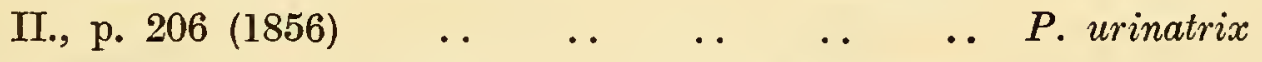

Puffinuria, Lesson, Voy. "Coquille," I., p. 729, Pl. 46 (1826) ;

id., Traite d'Orn., p. 614 (1831) _. $\quad$. . $\quad$. . $\quad$ P. urinatrix

THE Diving Petrels show a remarkable similarity in appearance to the Little Auk of the Northern Hemispheres, and even the habits of the two forms, though separated from each other by the entire Temperate and Equatorial areas of the Globe, are almost similar.

Key to the Species.

a. Smaller; wing, 4.3-5.2 inches.

$a^{\prime}$. Throat, flanks, and under wing-coverts nearly pure white; flanks sometimes ashy .. $\quad$.. urinatrix, p. 299 


\section{MONOGRAPH OF THE PETRELS.}

$b^{\prime}$. Throat, flanks and under wing-coverts grey, as also the fore-neck and sides of neck . . $\quad$. exsul, p. 304

b. Larger ; wing, 5.35-5.75 inches; bill and feet very

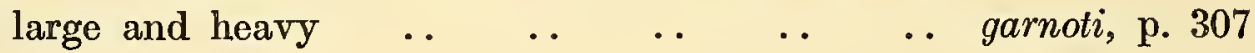

\section{FAMILY IV.-DIOMEDEID $A$.}

(Salvin, Cat. Birds Brit. Mus., XXV., p. 440, 1896.)

\section{Key to the Genera.}

a. With no longitudinal groove on the under mandible; tail short and rounded.

$a^{\prime}$. Base of the culminicorn wide, joining the proximal end of the dorsal edge of the latericorn

Diomedea

$b^{\prime}$. Base of the culminicorn narrower, divided by a membrane from the latericorn .. $\quad . \quad$. . Thalassogeron

b. With a longitudinal groove on the under mandible;

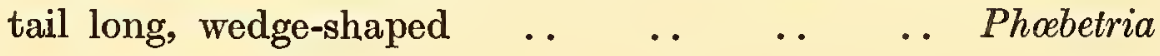

The above characters are taken from Salvin's "Catalogue," but I have examined several species of Thalassogeron and Diomedea, which were almost inseparable generically. Mr. Pycraft, however, has found some osteological characters which he considers to be sufficient for their separation. He sends me the following note on the subject:-

"Thalassogeron may be readily distinguished from Diomedea, in so far as cranial characters are concerned, in the much greater width of the interorbital region of the frontals, and in the greater width of the palatine ends of the pterygoids.

"These characters sharply define Thalassogeron from Diomedea, but Diomedea melanophrys presents in all other respects an extremely close resemblance to Thalassogeron, so much so as to make it probable that this species has been wrongly placed in the genus Diomedea. Like Thalassogeron, it presents a peculiarly inflated lachrymæ, and this seems to be met with in no other member of the genus Diomedea. If $D$. melanophrys were removed from Diomedea, then that genus would be very sharply defined indeed from Thalassogeron. But they are still separable on account of the characters given above." 


\section{CLASSIFICATION.}

\section{XXIII.-Diomedea, Linn.}

Diomedea, Linn., Syst. Nat., i., p. 214 (1766) ; Bp., Consp.

Type

Av., II., p. 184 (1855) ; Coues, Pr. Acad. Nat. Sci.

Philad., 1866, p. 175 ; Forbes, Voy. "Challenger,"

Zool., IV., pt. XI., p. 42 (1882) ; Salvin, Cat. Birds

Brit. Mus., XXV., p. 440 (1896) _. $\quad$. $\quad$.. D. exulans

Phoebetria, Reichenbach, Syst. Av., p. $\nabla .(1852) \quad \ldots \quad$.. D. albatrus

Thalassarche, Reichenbach, Syst. Av., p. v. (1852); Forbes, Voy. "Challenger," Zool., IV., pt. XI., p. 57

Key to the Species.

a. Larger; bill very strong; interscapular region and middle of back white.

$a^{\prime}$. Head white.

$a^{\prime \prime}$. Upper back with narrow transverse dark lines; wing-coverts dark slaty-black, the smaller coverts becoming nearly white towards the edge of the wing; exposed portion of the primaries beneath black. Young bird brown, face white .. $\quad . . \quad$.. exulans, p. 309

$b^{\prime \prime}$. Upper back without transverse dark lines; longer scapulars blackish at the ends; wing-coverts dark grey irregularly mottled towards the edge with white; exposed portion of primaries beneath black. Young bird white, from the downy nestling .. regia, p. 319

$c^{\prime \prime}$. Upper back without transverse dark lines; scapulars white, faintly banded with narrow dark lines; wing-coverts nearly white, the middle coverts only variegated with black; exposed portion of primaries beneath with a large white patch on the inner webs .. chionoptera, p. 322

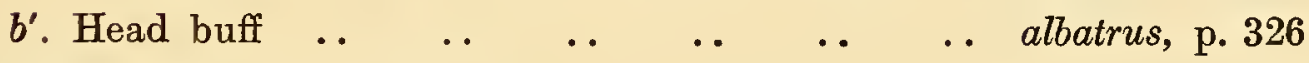

b. Smaller; bill more slender.

$c^{\prime}$. Interscapular region and the middle of the back sooty-black or brown. 


\section{MONOGRAPH OF THE PETRELS.}

$d^{\prime \prime}$. Abdomen dark, closely freckled with white irrorata, p. 330

$e^{\prime \prime}$. Abdomen sooty brown $\quad \ldots \quad \ldots \quad \ldots \quad$ nigripes, p. 332

$f^{\prime \prime}$. Abdomen pure white .. $\quad . . \quad \ldots \quad \ldots$ immutabilis, p. 336

$d^{\prime}$. Interscapular region and middle of the back slaty-black.

$g^{\prime \prime}$. Bill entirely yellowish horn-colour .. . . melanophrys, p. 339

$h^{\prime \prime}$. Bill, culmen, and lower edge of mandible yellowish horn-colour; sides of bill slaty; crown of head white $\quad . \quad \ldots \quad$.. bulleri, p. 344

$i^{\prime \prime}$. Bill black, the culmen paler; crown of head smoky-grey like the hind neck $\quad$. platei, p. 346

\section{XXIV.-Thalassogeron, Ridgway.}

Thalassogeron, Ridgway in Baird, Brew. and Ridgway, WaterType

Birds N. Amer., II., pp. 345, 357 (1884) ; Salvin,

Cat. Birds Brit. Mus., XXV., p. 449 (1896).. . . T. culminatus

Thalassarche, Forbes (nec Reichenb.), Voy. "Challenger,"

Zool., IV., pt. XI., p. 57 (1882).

Key to the Species.

a. Culmen, in adult, bright yellow; sides of the bill black.

$a^{\prime}$. Culminicorn rounded posteriorly; lower edge of

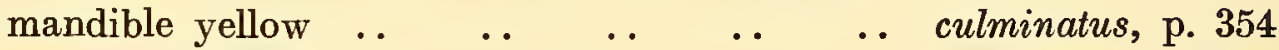

$b^{\prime}$. Culminicorn pointed posteriorly; base of mandible yellow, but not the lower edge.

$a^{\prime \prime}$. A yellow vertical line at the base of the $\begin{array}{lllllll}\text { mandible } & . & \ldots & \ldots & \ldots & \ldots & \text { chlororhynchus, p. } 357\end{array}$

$b^{\prime \prime}$. No yellow vertical line at the base of $\begin{array}{lllllll}\text { mandible } & \ldots & \ldots & \ldots & \ldots & \ldots & \text { eximius, }\end{array}$

b. Bill generally pale, the sides not black and the culmen not distinctly yellow.

$c^{\prime}$. Whole head and neck nearly pure white.

$c^{\prime \prime}$. Bill very stout; tarsi and toes longer .. cautus, p. 348

$d^{\prime \prime}$. Bill more slender; tarsi and toes shorter layardi, p. 353 


\section{CLASSIFICATION.}

$d^{\prime}$. Whole head and neck (except the white crown) $\begin{array}{llllllll}\text { grey .. } & \ldots & \ldots & \ldots & \ldots & \ldots & \ldots & \text { salvini, p. } 351\end{array}$

c. Bill entirely black, including the culmen .. . . carteri, p. 361

XXV.-Phabetria, Reichenb.

Phoebetria, Reichenbach, Syst. Av., p. จ. (1852); Coues, Type

Proc. Acad. Philad., 1866, p. 186; Forbes, Voy.

"Challenger," Zool., IV., pt. XI., p. 42 (1882);

Ridgway, Man. N. Amer. Birds, p. 53 (1887); Salvin,

Cat. Birds Brit. Mus., XXV., p. 453 (1896) .. $\quad$.. $\quad P$ fuliginosa

Diomedea (part), Bp., Consp. Av., II., p. 184 (1855).

Key to the Species.

a. Mantle and back sooty-brown; horizontal groove on

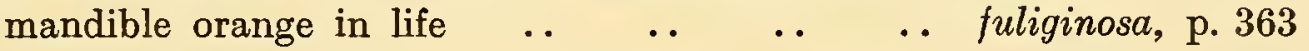

b. Mantle and back ashy-grey; horizontal groove on mandible pale blue in life .. $\quad \ldots \quad \ldots \quad \ldots$ cornicoides, p. 367 




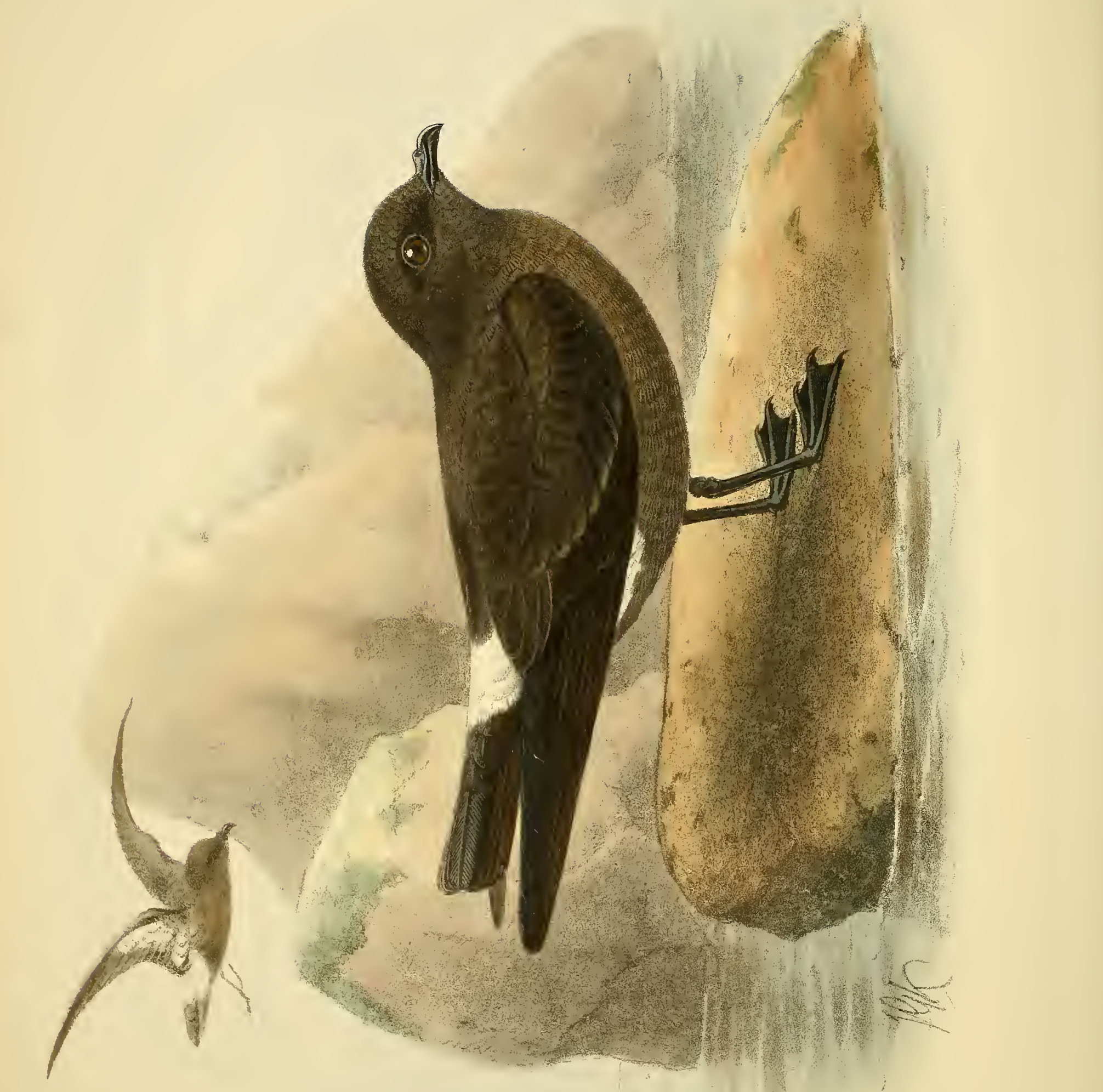

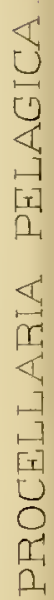




\title{
1. PROCELLARIA PELAGICA, Linn.
}

\section{(STORM-PETREL.)}

\author{
(Plate 1.)
}

Procellaria pelagica, Linn., Syst. Nat., I., p. 212 (1766) ; Salvin, Cat. Birds Brit. Mus., XXV., p. 343 (1896); Sharpe, Handl. Birds, I., p. 120 (1899).

Stormy Petrel, Lath., Gen. Syn. Birds, III., pt. 2, p. 411 (1785).

Hydrobates pelagica, Boie, Isis, 1822, p. 562.

Thalassidroma pelagica, Vigors, Zool. Journ., II., p. 405 (1826).

Hydrobates faeroensis, Brehm, Vög. Deutschl., p. 803 (1831).

Thalassidroma melitensis, Schembri, Cat. Orn. Malta, p. 118, pl. 5 (1843).

Procellaria lugubris, Bp., Atti Sesta Riun. Sc. Ital. Milano, 1844, p. 445 (1845, ex. Natt.). Procellaria melanonyx, Bp., Consp., II., p. 197 (1857).

Fuliginoso-niger, quasi schistaceo adumbratus: uropygio imo et supracaudalibus albis, his late nigro terminatis: rectricibus nigris, basi ipsa alba: alis nigris, tectricibus majoribus et secundariis intimis albido marginatis: gastræo fuliginosonigro, crisso laterali albo : rostro pedibusque nigris : iride corylino.

The "Stormy Petrel," as this species has been called since the days of Latham, breeds on the Lofoten Islands, on the north coast of Norway, on the Faroes, the Orkney and Shetland Isles, and in suitable places on the west coast of the United Kingdom and northern France, as well as on several islands in the Mediterranean. In Western Europe, especially at the time of the autumn migration, or in rough weather, individuals are frequently driven far inland, and are picked up in an exhausted condition. The species is found on the eastern coast of North America, but there is as yet no record of its nesting there. That it does so is extremely probable, for Mr. L. M. Turner met with the species on the Kosoak River, in Labrador, on the 20th July, and observed another example on the same river in October.

After the breeding season, the Storm-Petrel is very widely distributed over the Atlantic Ocean, reaching the Cape of Good Hope, and even extending its range along the east coast of Africa, up to the latitude of Zanzibar. The Storm-Petrel of the 


\section{MONOGRAPH OF THE PETRELS.}

Mediterranean has been separated by Schembri and Bonaparte as a distinct species, which they named respectively $P$. melitensis and $P$. lugubris. I have not been able to examine any large series of specimens from Southern Europe, but I have compared a few individuals with others from more northern localities, without being able to detect any difference between them, either in plumage or measurements. Mr. Howard Saunders, after examining some Spanish examples, suggested that the white band on the rump was narrower in the southern birds, but I cannot confirm this character from the specimens I have examined.

Like most of the other Storm-Petrels, $P$. pelagica is crepuscular in its habits, and is consequently not often seen, except at sea. Its food consists of small fish, molluscs, crustaceans, or oily matter. I have myself seen them in great numbers feeding on the carcase of a dead whale. The nest consists of a few blades of rough grass, placed in rabbit-burrows or under stones. The parent birds, when taken from their hidingplaces, show but little inclination to fly, and usually crawl back into some dark retreat.

One of the best accounts of the nesting of this species is that given by Mr. W. Eagle Clarke in his essay on the "Birds of the Flannan Islands" (Ann. Scott. Nat. Hist., 1905, p. 85). He writes as follows:- "The Storm-Petrel is very numerous during the summer, when they fly noisily about the islands during the night-time. They breed on Eilean Mhor, and probably on the other islands, in abundance. Many chicks, some of them quite recently hatched, were found during our visit in September, and we saw young ones in every stage from a few hours old (tiny balls of pretty lavender-grey down) to birds full-grown and fully feathered, except that they had a bunch of down still present on the lower part of the abdomen. The old birds are entirely absent during the day-time, leaving even the small chicks to take care of themselves, and do not return until darkness sets in, when they tend their young and depart again early in the morning, probably to spend the day far out at sea in search of food. We opened out a number of their nesting-holes at all hours of the day, but the old birds were always absent, except in one instance, where the young had only recently emerged from the egg. Occasionally they visited the lantern. They nest in the remains of the old buildings, in holes in turf, and under stones among grass. The nest is a mere mat composed of dry roots, grass, etc. I received a young one in full down, which had been taken on the 3rd October; probably the first egg of this pair had been taken or destroyed."

The egg is white, with a sprinkling of minute reddish-brown dots, frequently forming a distinct zone round the larger end. The series in the British Museum measures : axis, 1.15-1.2 inch ; diam., 0.85-0.9.

Adult male. General colour above sooty-black, with a slight plumbeous gloss; wing-coverts like the back, with obsolete white fringes to the greater series; quills and tail-feathers black; the outer feathers white at base, with black shaft-streaks; upper 


\section{PROCELLARIA PELAGICA.}

tail-coverts white, the longer coverts broadly tipped with black; under-surface of body rather more smoky-brown than the back, with a patch of white on each side of the lower flanks, adjoining the white patch on the upper-surface; under tail-coverts smoky brown like the abdomen; under wing-coverts sooty-black, the greater series white at the ends, forming a patch; axillaries also sooty-black, the longer ones with broad white ends; bill and feet black; iris hazel. Total length, 6.5 inches; culmen, 0.45 ; wing, 4.7 ; tail, 2.1 ; tarsus, 0.95 ; middle toe and claw, 0.8 .

Adult female. Similar to the male. Total length about 6.19 inches; wing, 4.85 ; tail, 2.2 ; tarsus, 0.9 ; middle toe and claw, 0.8 .

Young. At first covered with long down of a sooty ash-colour, making the bird look like a long-haired mouse, as no bill or wings are visible. When the down is shed, the plumage of the young bird is exactly similar to that of the adult, with the exception that the greater wing-coverts have a distinct, if narrow, margin of white. The scapulars and black tips of the upper tail-coverts also have nearly obsolete white fringes. These characters are clearly shown in a specimen from Syre, Sutherlandshire, presented to the British Museum by Mr. H. St. George Peacock. It was obtained on the 19th October, 1900, and is full-grown, but with some remains of the nestling down on the abdomen.

The specimen figured is in our own collection, and was obtained in the Orkneys by the late John Dunn. The male described is in the Seebohm Collection, and was procured on the Lincolnshire coast on the 10th November. The female was obtained in the North Atlantic during the voyage of the "Herald." 


\title{
2. PROCELLARIA TETHYS, $B p$.
}

\author{
(GALAPAGOS STORM-PETREL.)
}

\section{(Plate 2.)}

Procellaria tethys, Bp., J.f.O. 1853, p. 47 ; Salvin, Tr. Z. S., IX., p. 507, pl. 88, fig. 2 (1876) ; id., Cat. Birds Brit. Mus., XXV., p. 346 (1896); Rothsch. and Hartert, Nov. Zool., VI., p. 199 (1899); id., Nov. Zool., IX., p. 416 (1902); Godman, Biol. Centr.-Amer., Aves, III., p. 427 (1904).

P. pelagicoe similis, sed tectricibus alarum majoribus cinerascenti-brunneis, albo marginatis, plagam pallidam exhibentibus: sub-alaribus fuliginosis, haud albo variegatis: supracaudalibus albis, minime nigro terminatis, scapis tamen nigricantibus, distinguenda.

THIS SPECIES is allied to the common Storm-Petrel, but may at once be distinguished by the entirely white upper tail-coverts, which are not tipped with black, as in $P$. pelagica. The greater wing-coverts have no white margins, but are ashy-brown, thus forming a patch, while the under tail-coverts are uniformly sooty-brown, without any admixture of white.

This little Petrel is plentiful throughout the Galapagos, but appears to be more abundant in the south of that archipelago, and is frequently encountered far out at sea. The Hon. Walter Rothschild and Dr. Hartert record that the Webster-Harris Expedition procured specimens near Wenman, Culpepper, Albemarle, and Tower Islands, and the species was also met with by Mr. Beck, on Bindloe and N. Albemarle Islands, and at sea in Lat. $1^{\circ} \mathrm{N}$., Long. $39^{\circ} \mathrm{W}$. Dr. C. H. Townsend has also recorded its occurrence in Lat. $40^{\circ} 22^{\prime}$ N., Long. $82^{\circ} 33^{\prime}$ W., about $400-600$ miles east of the Galapagos Islands (Pr. U.S. Nat. Mus., XIII., p. 142).

Salvin (Cat. Birds Brit. Mus., XXV., p. 344) has given the range of $P$. tethys as extending to the west coast of Central America, for which reason I included it in the "Biologia," but I have not discovered the grounds for this record (cf. Biol. Centr.Amer., Aves, III., p. 427).

The nesting-place of the species is at present unknown, but it is doubtless in some of the islands of the Galapagos Archipelago, for Mr. Beck saw the birds in thousands 


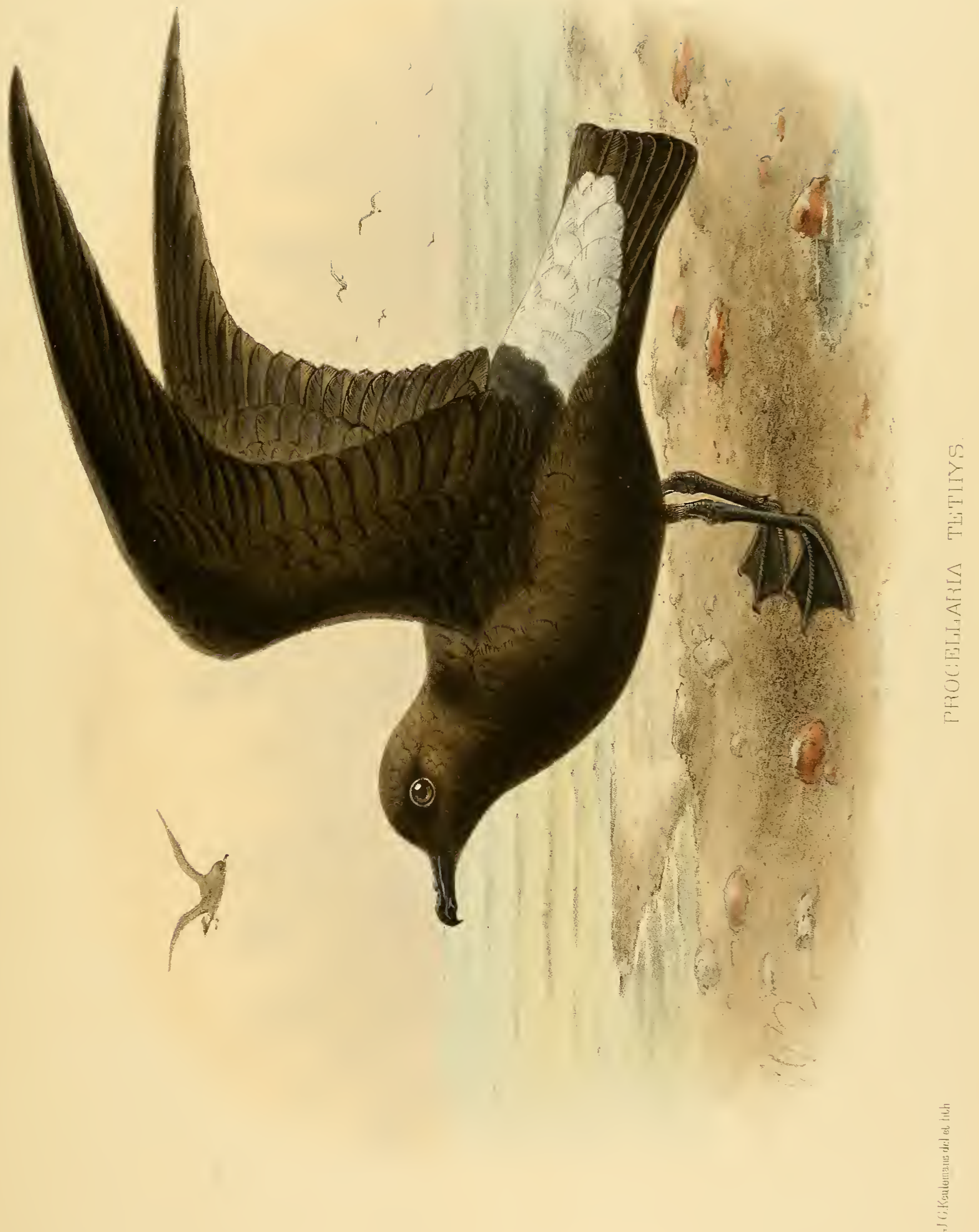





\section{PROCELLARIA TETHYS.}

in the neighbourhood of Tower Island, and discovered a colony there, apparently breeding, but he found no eggs (Condor, IV., p. 99).

Adult male. Sooty-black above and below, with a very slight plumbeous gloss; wing-coverts like the back, but the greater series light brown, forming a wing-patch; lower rump and upper tail-coverts pure white, with hair-like black shaftlines; quills and tail-feathers black; under-surface of body a little more ashy than the back, with a small patch of white on the sides of the vent, adjoining the white upper tail-coverts; under wing-coverts and axillaries like the breast, with no white on the lesser series or axillaries ; bill and feet black ; iris dark brown. Total length, 6 inches ; culmen, 0.5 ; wing, 5.2 ; tail, 2.3 ; tarsus, 0.85 ; middle toe and claw, 0.7 .

Adult female. Similar to the male in colour. Total length about 5.8 inches; wing, 5.2 ; tail, 2.3 ; tarsus, 0.95 ; middle toe and claw, 0.7 .

The specimen figured is in the British Museum, its origin is not known, but was obtained probably from Kellett and Wood's Voyage. The male described is from Culpepper Island, and the female from Wenman Island; both specimens are in the British Museum, from the Webster-Harris Expedition. 


\title{
3. HALOCYPTENA MICROSOMA, Coues.
}

\author{
(LEAST PETREL.)
}

\section{(Plate 3.)}

Halocyptena microsoma, Coues, Proc. Philad. Acad., 1864, pp. 79, 90 ; Baird, Brewer, and Ridgway, Water Birds N. Amer., II., p. 402 (1884); Salvin, Cat. Birds Brit. Mus., XXV., p. 346 (1896) ; Anthony, Condor, II., p. 29 (1900) ; Godman, Biol. Centr.-Amer., Aves, III., p. 428 (1904).

Procellaria microsoma, Gray, Handl. Birds, III., p. 104, No. 10,859 (1871).

Fuliginoso-nigra, subtus paullo brunnescentior: tectricibus alarum majoribus pallidioribus, cinerascenti-brunneis : cauda cuneata et albedine nulla insignis.

The Least Petrel may be easily recognised by its small size and wedge-shaped tail. The specimens in the British Museum vary somewhat in dimensions, the wing in the male being 4.85 inches, and in the female from 4.75 to 5.05 inches.

The late John Xantus first discovered this little Petrel off San José del Cabo, in Lower California, and it has since been found breeding by Mr. A. W. Anthony on San Benito Island. A single female was likewise obtained by Mr. A. Forrer off the coast of Mazatlan (Biol. Centr.-Amer., Aves, III., p. 428), and Dr. C. H. Townsend records the capture of a specimen which flew on board the surveying ship "Albatros," in the Bay of Panama in March, 1888 (Pr. U.S. Nat. Mus., XIII., p. 141). In his account of a "Night on Land in San Benito Island" (Condor, p. 28, 1900), Mr. Anthony states that he found this bird on loose rocky ledges, or under stones, and on one occasion he met with no less than twenty-eight of them, crowded together in a small space in a wall of rock not more than seven feet wide and two high. He did not, however, observe them on the other islands off the coast. He describes the cry as similar to that of Oceanodroma melania and $O$. socorroensis, but higher pitched, and giving the idea of a smaller bird; he says that the note resembled the whirring of a rapidly revolving cog-wheel.

Eggs in the British Museum, collected by Mr. Anthony, are elliptical in shape, white, without any conspicuous rufous dots. Axis, 1.05 to 1.1 inch ; diam., 0.75 to 0.9 .

Adult male. Sooty-black, the under-surface slightly brown in shade, the greater wing-coverts paler and ashy-brown, forming a wing-patch; quills and tail-feathers 
IUEIIAFES. FATE

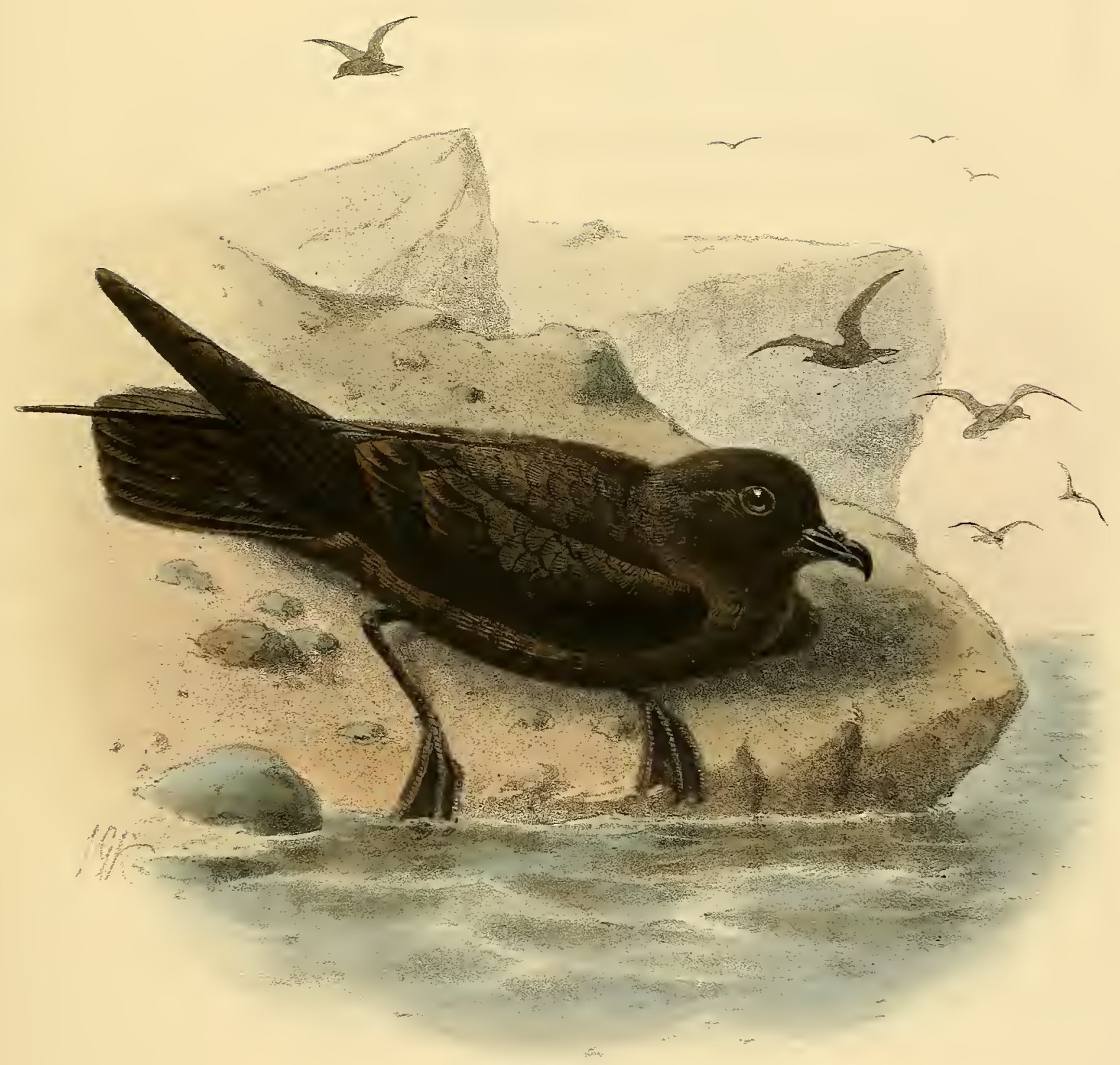





\section{HALOCYPTENA MICROSOMA.}

black; under wing-coverts dark sooty-brown, like the breast, those round the edge of the wings forming a black band, scarcely distinguishable; bill and feet black. Total length about 5.5 inches; culmen, 0.4 ; wing, 4.85 ; tail, 2 ; tarsus, 0.85 ; middle toe and claw, 0.7 .

Adult female. Similar to the male. Total length about 6.5 inches ; culmen, 0.4 ; wing, 5.05 ; tarsus, 0.85 ; middle toe and claw, 0.8 .

The descriptions are taken from a pair of birds in the British Museum, collected by Mr. Anthony on San Benito Island. The specimen figured is the bird obtained by Mr. Forrer, off Mazatlan, formerly in our collection, and now in the British Museum. 


\section{OCEANODROMA LEUCORRHOA (Vieill.).}

\section{(LEACH'S PETREL.)}

(Plate 4.)

Procellaria pelagica (nec Linn.), Pall., Zoogr. Rosso-Asiat., II., p. 316 (1811). Cf. Stejneger, Orn. Expl., Comm. Isl. and Kamtsch., p. 97 (1885).

Procellaria leucorhoa, Vieill., N. Dict. d'Hist. Nat., XXV., p. 422 (1817).

Procellaria leachi, Temm., Man. d'Orn., II., p. 812 (1820); Sharpe, Hist. Coll. Brit. Mus., II., p. 222 (1906).

Procellaria bullocki, Fleming, Brit. An., p. 136 (1828).

Thalassidroma leachi, Audub., Orn. Biogr., III., p. 434 (1835).

Fork-tailed Petrel, Yarrell, Brit. Birds, III., p. 520 (1843).

Thalassidroma scapulata, Kittl., Denkw., II., p. 191 (1858).

Cymochorea leucorrhoa, Coues, Pr. Philad. Acad., 1864, p. 75.

Oceanodroma leucorrhoa, Stejneger, Orn. Expl., Comm. Isl. and Kamtsch., p. 97

(1885) ; Salvin, Cat. Birds Brit. Mus., XXV., p. 348 (1896).

Hydrobates leucorrhoa, Löns, J.f.O., 1906, p. 221.

Fuliginoso-niger, schistaceo adumbratus ; tectricibus majoribus pallidioribus, cinerascenti-brunneis; supracaudalibus albis, vix nigro terminatis; cauda valde furcata.

Juv. adultis similis, sed tectricibus alarum majoribus et secundariis extus grisescentialbis distinguendus.

Leach's Petrel, often called the "Fork-tailed Petrel," constantly occurs on the British coasts, and, like Procellaria pelagica, is not infrequently blown far inland by heavy gales during spring and autumn.

This species breeds on St. Kilda and several of the Outer Hebrides, as well as the Blaskets and other rocks on the west coast of Ireland. Although found at various seasons throughout the North Atlantic, and visiting Norway and Iceland, it is not known to breed in the last-named localities. Westward its range extends from Greenland and Labrador, south to the coast of Virginia, and it breeds from the coast of Maine northward. 


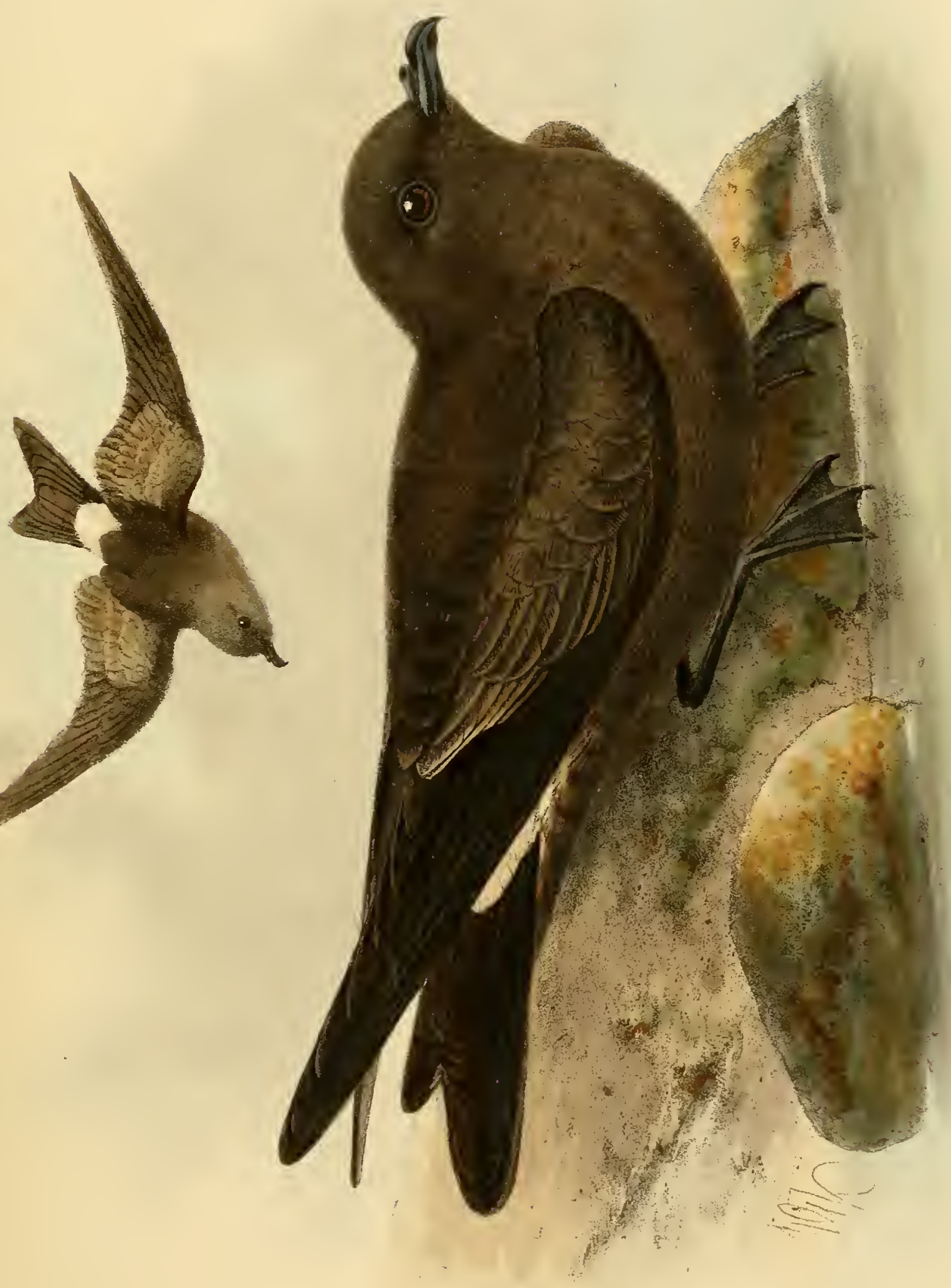

$\sum$
0
$\vdots$
0
0
$z$
3
0 



\section{OCEANODROMA LEUCORRHOA.}

In the North Pacific it nests on the Aleutian Isles, and Dr. Stejneger (l.c.) found it breeding on Copper Island, in Bering Sea, though, according to Mr. Emerson, it is his $O$. beldingi, and not $O$. leucorrhoa, which inhabits these islands. The Hon. Walter Rothschild possesses specimens from the islands of Memoshiri and Otoke, off the Japanese island of Yezo.

On the Pacific side of America, Leach's Petrel is believed to range to the islands off the coast of California, having been recorded by Mr. Loomis as nesting on the Farallon Islands (Proc. Calif. Acad. Sci. (2), VI., p. 259), but this record has not been confirmed by subsequent observers.

I have examined specimens in the Hon. Walter Rothschild's Museum, procured by Mr. Beck in Lat. $5^{\circ} 30^{\prime}$ N., Long. $102^{\circ}-103^{\circ} \mathrm{W}$., which had the wing 6.1 to 6.3 inches in length, and appeared to me to be inseparable from a series of specimens of typical O. leucorrhoa, as did also some other examples collected by Mr. Beck near the Galapagos Islands, in Lat. $13^{\circ} 20^{\prime}$ S., Long. $167^{\circ} 10^{\prime} \mathrm{W}$.

The southern distribution of Leach's Petrel does not extend as far as that of $P$. pelagica, since we have no certain records of its occurrence in the Cape seas or in the Indian Ocean, but Mr. M. J. Nicoll, when accompanying the Earl of Crawford as naturalist on board the "Valhalla," observed it between St. Paul's Rocks and Bahia. There is a specimen in the British Museum said to have been procured in the Cape Seas by Sir Andrew Smith, but I imagine that this bird was obtained by him in more northern waters, on one of his voyages to the Cape. It should be noted, however, that the British Museum has recently received a specimen of Leach's Petrel from the Gold Coast.

Mr. Meade-Waldo obtained an example of this species near Orotava in Tenerife, and Mr. Nicoll states that it followed the "Valhalla" to a little south of the Line. The same observer also states that $O$. leucorrhoa was seen in the Mediterranean two days after leaving Port Said for Gibraltar (Ibis, 1906, p. 711).

Mr. Eagle Clarke (Ann. Scott. Nat. Hist., 1905, p. 85) considers the Flannan Islands to be one of the principal breeding-places of Leach's Petrel in the British area; and he says that it was there more abundant than $P$. pelagica, which it resembled in its habit of noisily flying about during the long summer nights.

The eggs were laid somewhat earlier than those of the Storm-Petrel, the first being found on May 29th, but the nesting habits of the two species were very similar. The nests themselves were composed of matted grass and were to be found in burrows, holes in rocks or old walls, and showed but little signs of the in-comings or out-goings of the parent birds. The latter were seldom visible during the day, but might occasionally be seen at night attracted by the light of the lantern.

Eggs of Leach's Petrel in the British Museum are white, minutely speckled with reddish dots at the larger end. Axis, 1.15-1.35 inch; diam., 0.95-1.0.

Adult male. Sooty-brown, with a decided gloss of slaty-grey; the under-surface 


\section{MONOGRAPH OF THE PETRELS.}

rather browner, with a distinct shade of slaty-grey on the throat, sides of face, and sides of neck; lesser wing-coverts black ; the median and greater coverts drab-brown ; the latter, as well as the inner secondaries, narrowly fringed with white; primarycoverts and quills black, the inner secondaries browner, like the scapulars; lower rump sooty-brown, like the back, with some more or less white feathers on each side ; upper tail-coverts white, with dusky shaft-lines, the lateral ones fringed with white at the tip, the central ones for the most part ashy-brown, more or less centred with white; tail-feathers black; head and neck dusky-brown, with an evident plumbeous shade; the under tail-coverts sooty-brown; some of the lateral coverts more or less white at their base; under wing-coverts and axillaries brown like the breast, the lower primarycoverts and quill-lining somewhat more ashy-brown. Total length about 8 inches; culmen, 0.7 ; wing, 6.1 ; tail, 3.1 ; fork of tail, 0.85 ; tarsus, 1 ; middle toe and claw, 1.05 .

Adult female. Similar in colour to the male. Total length 8 inches; wing, 6.3.

A nestling from Casco Bay, Maine, is covered with long down of a sooty-brown colour, and very woolly in texture.

A good deal of variation takes place in the amount of white edging to the drab greater wing-coverts, and also in the dusky markings on the white upper tail-coverts. Sometimes the lateral coverts are narrowly fringed with dusky markings at the tip, and at others the black tips are as broad as in $O$. castro, which species, however, is easily distinguished by its white lateral under tail-coverts. I imagine that the white edgings to the wing-coverts are broader and more distinct in the younger birds, though there is really very little difference in plumage between the mature and immature birds in all the species of Fork-tailed Petrels.

The specimens described are a pair of nesting birds obtained on St. Kilda by Mr. Charles Dixon in June, 1884, and now in the Seebohm Collection in the British Museum.

The bird figured in the Plate is an adult male from Grand Menan, New Brunswick, in our own collection. It should be observed that the lighter brown wing-patch is not sufficiently indicated in the picture. 


\title{
5. OCEANODROMA BEALI, Emerson.
}

\author{
(BEAL'S STORM-PETREL.)
}

Oceanodroma beali, Emerson, Condor, VIII., p. 54 (1906).

O. leucorrhoce similis, sed conspicue minor.

Mr. W. Oтto Emerson has recently described a form of $O$. leucorrhoa from the North Pacific Ocean. The type specimens are a male and female from Sitka Bay, Alaska, in the collection of Mr. J. Grinnell. The measurements are given as follows :-

б. Wing, 5.90 inches ; tail, 3.10 ; forking of tail, 0.80 ; tarsus, 0.87 .

९. Wing, 5.75 inches ; tail, 3.10 ; forking of tail, 0.70 ; tarsus, 0.90 .

These dimensions are certainly rather smaller than those of 0 . leucorrhoa. A male from Egg Island, Alaska, in the Hon. Walter Rothschild's Museum, has the wing 6.2 inches and a female 5.9, the latter equalling the wing of the male O.beali. Specimens from the islands near Yezo (Memoshiri and Otoke: Mus. Rothschild) have the wing 6.0-6.1 inches. In the large series of Leach's Petrel in the British Museum, I find that the wing measures from 6.0-6.6 inches in specimens from Western Europe and the Atlantic Ocean ; 6.2-6.3 inches in examples from Japan and the Kurile Islands, and 6.1-6.5 inches in those from Eastern North America.

A specimen in the Rothschild Museum, collected by Mr. Beck in Lat. $5^{\circ} 30^{\prime} \mathrm{N}$., Long. $102^{\circ} \mathrm{W}$, has the wing 5.8 inches. If fully grown (which I am inclined to doubt) this may be a specimen of the $O$. beali, and represents its southern range, but the other specimens obtained by Mr. Beck in the same latitudes appear to me to be true $O$. leucorrhoa, the wing being 6.1 inches in length.

Mr. Emerson states that $O$. beali breeds on the Aleutian and Copper Islands, and on the islets of Sitka Bay, Alaska. Specimens from these localities have hitherto been assigned to $O$. leucorrhoa (vide antea).

It must be remembered that Petrels vary greatly in dimensions, and there is nothing wonderful in the variation in measurements between true O. leucorrhoa and $O$. beali. It is, however, difficult to determine the value of the latter species without seeing specimens from the typical locality; but I am inclined to doubt the distinctness of $O$. beali from $O$. leucorrhoa. 


\title{
6. OCEANODROMA BELDINGI, Emerson.
}

\section{(BELDING'S FORK-TAILED PETREL.)}

\author{
Oceanodroma beldingi, Emerson, Condor, VIII., p. 54 (1906).
}

O. beali similis, sed cinerascentior, alis caudaque brevioribus.

Mr. Emerson has described this species from five specimens in the collection of Mr. Herman T. Bohlman, the actual type being from Netarts Bay on the coast of Oregon. The range of this Petrel is given as the North Pacific Coast, from Vancouver Island to Northern California, breeding on the coast of Oregon and Mendocino County, California. Mr. Emerson describes it as a "handsome new Petrel," and says that it is " similar to $O$. beali, but decidedly greyer, and averaging notably smaller in length of wing and tail." The average measurements of five specimens are given by Mr. Emerson as follows :-Wing, 5.65 inches ; tail, 3.22 ; forking of tail, 0.67 ; tarsus, 0.78 .

Comparing these dimensions with those of 0 . leucorrhoa, the measurements of a series of the latter species were:-Wing, 5.85-6.34 inches; tail, 3.20-3.35; forking of tail, 0.75-0.90; tarsus, 0.90-0.91 (Emerson, l.c.). The describer of the species gives the following diagnosis :- "Uniform sooty-brown, washed with a bluish slate-grey on the head, throat, chest, and back, the grey most pronounced on the head and chest; forehead, chin, and upper throat decidedly ashy; greater and median wing-coverts edged with ashy; upper tail-coverts white with black shafts; lateral lower coverts edged with whitish ; rectrices black with white at base."

Not having examined a specimen of $O$. beldingi, I have compiled the above description from Mr. Emerson's notes. 


\section{OCEANODROMA KGEDINGI, Anthony.}

\section{(KEDING'S STORM-PETREL.)}

Oceanodroma koedingi, Anthony, Auk, XV., pp. 37, 314, 317 (1898) ; Rothsch. and Hartert, Nov. Zool., IX., p. 415 (1902); A.O.U., 9th Suppl., Auk, XVI., p. 101 (1899); Godman, Biol. Centr.-Amer., Aves, III., p. 429 (1904); Emerson, Condor, VIII., p. 54 (1906).

O. leucorrhoce similis, sed minor: cauda minus furcata: tectricibus supracaudalibus exterioribus omnino pure albis, nonnullis medianis medialiter nigricantibus vel cineraceis : pedibus debilioribus.

Keding's Storm-Petrel is a small dark form of $O$. leucorrhoa, with a less deeply forked tail. The lateral upper tail-coverts are entirely pure white, the median ones being blackish or ashy in the centre. The feet are less robust than in $O$. leucorrhoa, the middle toe and claw measuring only 0.8-0.9 inch in length, whereas in O. leucorrhoa they are fully an inch long.

For a Storm-Petrel $O$. kcedingi has a somewhat restricted range, its habitat being given by Mr. A. W. Anthony, who discovered the species, as from the Revillagigedo Islands and the island of Guadalupe, northwards to the coast of southern California (Auk, XV., p. 37). The first specimen of this Storm-Petrel was obtained by Mr. Anthony at sea, near the island of Guadalupe, on the 25th July (t.c., p. 37). $\mathrm{He}$ states that it was also commonly met with near Socorro Island, in the Revillagigedo Archipelago, apparently migrating (t.c., p. 314), and likewise in the vicinity of Clarion Island, in the same group (t.c., pp. 314, 317).

According to the same observer, numbers were seen at sea off the San Benedicte Islands as late as lst June; but he found no evidence of the nesting of the species there, probably owing to the prevalence of the large number of land-crabs which infest the burrows all over the islands, and which would probably destroy the eggs and young birds (t.c., p. 314).

Three specimens procured by Mr. Beck in Lat. $18^{\circ} \mathrm{N}$., Long. $103^{\circ} \mathrm{W}$., and in Lat. $5^{\circ} 30^{\prime} \mathrm{N}$., Long. $102^{\circ} \mathrm{W}$, are now in the Hon. Walter Rothschild's Museum at Tring (cf. Rothsch. and Hartert, Nov. Zool., IX., p. 415, 1902).

The habits of this Storm-Petrel are doubtless similar to those of its congeners. Mr. Emerson (Condor, VIII., p. 54) says that, in comparison with O. leucorrhoa, 


\section{MONOGRAPH OF THE PETRELS.}

Koding's Petrel is much darker, being sooty-brown over the whole body, while the head is dark plumbeous. The rectrices are sooty throughout, or else but very slightly paler at the base. The tip, however, of the inner web of the outer feather is often paler, forming a noticeable spot in 83 per cent. of the specimens examined by Mr. Emerson, who says that he also found this character in one example of O. leucorrhoa in the United States National Museum, and then only on one outer tailfeather. He states, moreover, that the tail in $O$. kodingi is less deeply forked than in the other Pacific Coast forms.

Mr. Emerson gives the following measurements of 0 . kocdingi from a series of twenty-seven specimens from the vicinity of Guadalupe Island:-Wing, 5.45-5.80 inches ; tail, 2.45-2.84; forking of tail, 0.40-0.46 ; tarsus, 0.70-0.75.

The Hon. Walter Pothschild has kindly lent me his specimens of 0 . kcedingi, a species at present not represented in the British Museum, and I find that the wing measures from $5.5-6.3$ inches.

O. leucorrhoa, according to my measurements of the series in the Tring Museum, varies in length of wing from 5.9-6.3 inches, and Mr. Emerson records it as from 5.856.35 inches. From the above summary it will be seen that the difference in length of wing in the two species is not very pronounced.

As in 0 . socorroensis (=O. monorhis) there is considerable variation in the markings of the upper tail-coverts, certain specimens having the outer series white, while some of the central ones are mottled with ashy-grey; others have narrow black tips and black shaft lines. Mr. Anthony has also noticed the variation in the extent of the white on the upper tail-coverts. A few of the examples examined by him had these coverts black, with whitish patches on the sides, while one specimen had totally black coverts, but was otherwise similar to the white-rumped birds (Auk, XV., p. 37).

The difference between $O$. kocdingi and $O$. leucorrhoa has been given in the above description of the species, and it has not been considered necessary to give a coloured illustration of this Storm-Petrel. 



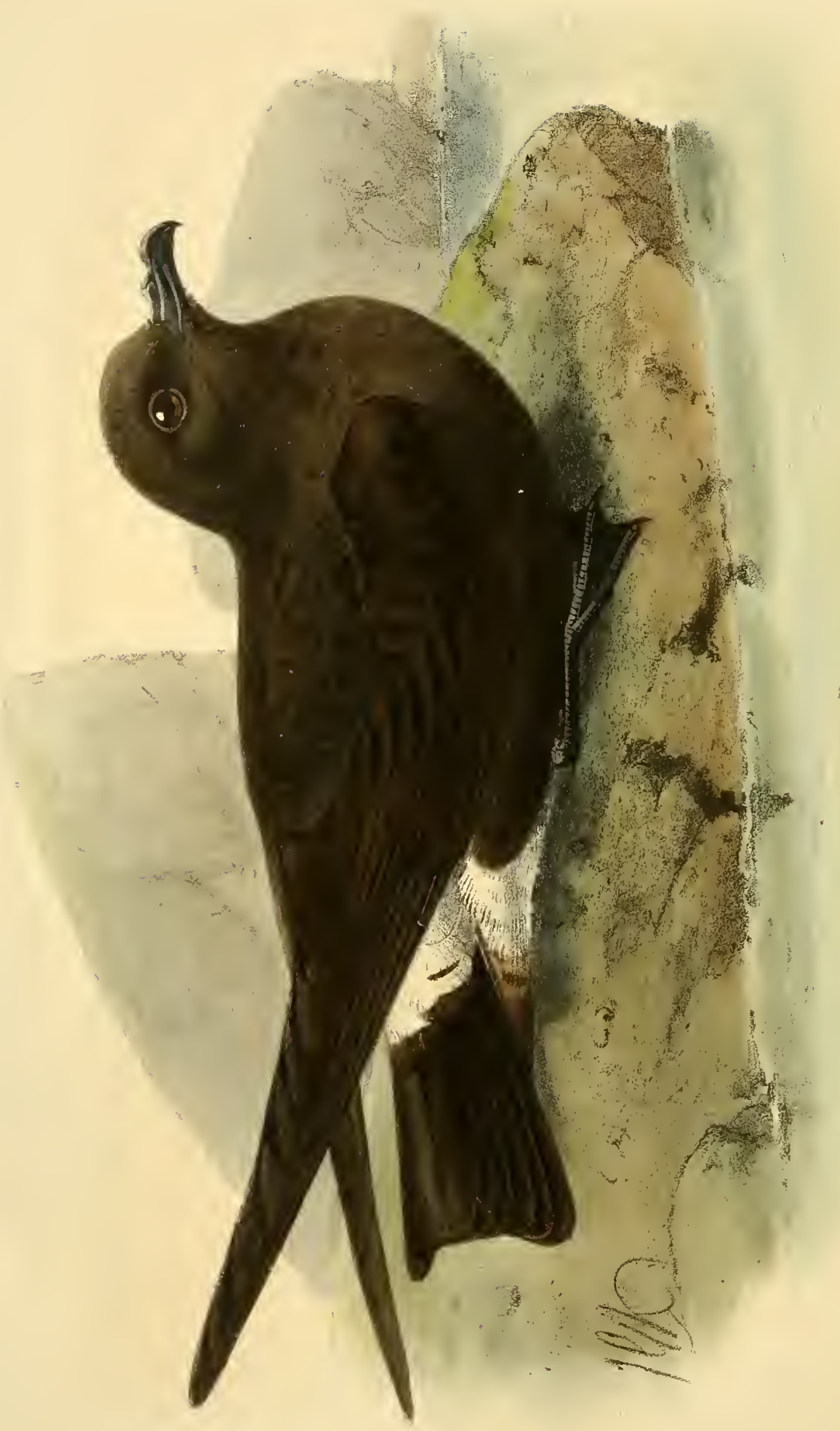

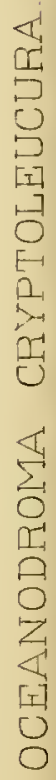




\section{OCEANODROMA CASTRO (Harcourt).}

\section{(MADEIRAN FORK-TAILED PETREL.)}

(Plate 5.)*

Thalassidroma castro, Harcourt, Sketch of Madeira, pp. 123, 166 (1851); id., Ann. and Mag. Nat. Hist. (2), XV., p. 436 (1855).

Thalassidroma jabe-jabe, Bocage, Jorn. Lisb., V., No. 18, p. 120 (1875).

Cymochorea cryptoleucura, Ridgway, Pr. U. S. Nat. Mus., IV., p. 337 (1882).

Oceanodroma cryptoleucura, Baird, Brewer, and Ridgw., Water Birds N. America, II., p. 406 (1884) ; Ogilvie-Grant, Ibis, 1896, p. 53 ; Salvin, Cat. Birds Brit. Mus., $\mathrm{XXV}$., p. 350 (1896) ; Boyd Alexander, Ibis, 1898, p. 96.

Oceanodroma castro, Sharpe, Handb. Brit. Birds, IV., p. 143, pl. CXIC.' (1897) ; OgilvieGrant, Ibis, 1898, p. 314 ; Rothsch. and Hartert, Nov. Zool., IX., pp. 415, 418 (1902) ; Godman, Biol. Centr.-Amer., Aves, III., p. 429 (1904) ; Hartert and Ogilvie-Grant, Nov. Zool., XII., p. 96 (1905).

Procellaria cryptoleucura, Winge, Vid. Medd. Kjöbenh., 1897, p. 246.

O. leucorrhoce similis, sed cauda minus furcata, supracaudalibus late nigro terminatis; rectricibus, mediis exceptis, basin versus albis.

THIS species is a form of $O$. leucorrhoa, with which it has often been confounded; but it is a somewhat smaller and blacker bird, having always black tips to the white upper tail-coverts and a white base to the outer tail-feathers. These characters serve to distinguish the two species, which would otherwise be somewhat difficult, for the markings of the upper tail-coverts in $O$. leucorrhoa vary considerably, occasionally showing dusky tips to the longer white tail-coverts.

For many years this Petrel remained unrecognised, and it was chiefly due to the description of $O$. cryptoleucura, from the Hawaiian Islands, by Professor Ridgway, that attention was drawn to this species of Fork-tailed Petrel. A further examination of Mr. Harcourt's description of $O$. castro led to the discovery that $O$. cryptoleucura was identical with the former species, of which a fine series of specimens has been obtained in Madeira and the neighbouring islands by Mr. Ogilvie-Grant and Padre Schmitz, as well as in the Azores by the first-named observer. Lieut. Boyd Alexander found the

* The Plate has been lettered Oceanodroma cryptoleucura. It must be remarked that the light brown patch on the wing should be more pronounced than it is in the illustration. 


\section{MONOGRAPH OF THE PETRELS.}

birds breeding on the Rombos Islands in the Cape Verde Archipelago (Ibis, 1898, pp. 96, 98).

Mr. Nicoll, who accompanied the Earl of Crawford on the cruise of the "Valhalla," saw large numbers of $O$. castro before reaching Grand Canary; and for the first two days after leaving Funchal, on my way back to Cadiz, in 1871, these birds were constantly seen flying round the ship.

The range of this species is a very wide one, extending from the Atlantic to the Pacific. It has been found in the neighbourhood of St. Helena, where a specimen was obtained by Governor Janish, which is now in the British Museum, but as yet we have no evidence of its occurrence in the Cape seas.

That it occasionally wanders northward is proved by its capture at Littlestone, in Kent, on the 5th December, 1895, as recorded by Mr. Howard Saunders (Bull. B. O. C., V., p. 37), the specimen being in Lieut. Boyd Alexander's collection; and another has been recorded from Hythe in Kent on the 8th of November, 1906, by Dr. N. F. Ticehurst (Bull. B. O. C., XIX., p. 10). Mr. Winge states that two specimens were obtained in the succeeding year off the coast of Denmark, one on September 19th on the lightship at Drogden, to the south of Copenhagen: the second at Kobbergrunden, in the Kattegat, on October 11th (Vid. Medd. Kjöbenh., 1897, p. 117).

In the Pacific Ocean $O$. castro has been found on Kauai, one of the Hawaiian Islands, and Mr. Perkins has reason to believe that it will be discovered on others of that group (Faun. Haw., Vol. I., pt. 4, p. 463). Mr. Bryan records it from French Frigate Island (Key Birds Haw., p. 13). A specimen procured at sea by Mr. Beck, in Lat. $5^{\circ}$ $30^{\prime}$ N., Long. $102^{\circ}$ W., is now in the Rothschild Museum at Tring.

In the Galapagos, Dr. C. H. Townsend noted these birds off Wenman and Albemarle Islands, and the Webster-Harris expedition met with them off Bindloe, Barrington and Abingdon Islands (Rothschild and Hartert, Nov. Zool., VI., p. 198 ; IX., pp. 415, 418).

This Petrel doubtless occurs off the Pacific coast of Central America (Godman, Biol. Centr.-Amer., Aves, III., p. 429), for a specimen was procured by Mr. Beck on the 12th of July, 1900, thirty-six miles north of San Benedicte, and is now in the Rothschild Museum. It has also been recorded from the United States, a specimen having been blown inland and captured at Monrovia, Indiana, and a second at Washington, D.C., in August, 1893 (Butler, $A u k$, 1906, p. 274).

No nesting-places of this Storm-Petrel have been discovered on the Pacific side of North America, nor in the Hawaiian Islands, and, so far as I know, the species is only known to breed on some of the Atlantic islands; thus it has been found nesting on Porto Santo, one of the Madeiran group, and on Lime Island, near Porto Santo (Grant, Ibis, 1896, p. 53). From the last-named island eggs have been forwarded to the British Museum by Padre Schmitz (cf. Oates, Cat. Eggs Brit. Mus., I., p. 148).

Nesting-places of this species were also found on Praya Island in the Azores by Mr. 


\section{OCEANODROMA CASTRO.}

Ogilvie-Grant (Nov. Zool., XII., p. 96), and again on the Cape Verde Islands, as recorded above.

Few notes on the habits of this Storm-Petrel have been published. It was seen in some numbers by Mr. Ogilvie-Grant flying round the steam-tug on his voyage to the Desertas and Porto Santo, where it breeds. Lieut. Boyd Alexander states that in the Cape Verde Islands, the burrows of this species run further into the ground, and are more tortuous than those of Pelagodroma marina. He observes:-- "When the night shadows began to brood vaguely over the lone wastes of the Rombos Islands, the Petrels came abroad and filled the still air with their weird cries. They mustered strongly, flitting to and fro over the low-lying ground in hundreds. Among the number the most noticeable was Puffnus assimitis, as it glided like some large soft-winged bat over the small sand-hills, and even brushing past our camp-fire, for ever uttering its weird cry, 'karki-karrou, karki-karrou, karki-karrou,' while amid these a similar but softer one would often strike fitfully upon the ear, coming from Oceanodroma castro as it flitted over the island."

The egg of $O$. castro is white, without any gloss, with a more or less evident zone of reddish dots round one end, but these dots are never conspicuous. Specimens in the British Museum measure : axis, 1.25-1.4 inch ; diam., 0.95-1.05.

Adult female. Above sooty brown, with a very distinct plumbeous gloss; scapulars and wing-coverts like the back, the greater series and the inner secondaries rather more ashy-brown and narrowly fringed with white; the innermost secondaries sooty-brown like the back; primary-coverts and quills black; upper tail-coverts white, with broad black tips, some of the centre ones with a sub-terminal spot of black; tail-feathers black, the outer ones having a distinct patch of white at the base; head and neck, sides of face and throat with a more distinct ashy shade than the back; remainder of under-surface from the lower throat lighter than the back and more smoky-brown; median under tail-coverts also smoky-brown, but the lateral ones pure white, or white shaded with ashy at the ends; a patch of white feathers on the lower flanks uniting with the white under tail-coverts; under wing-coverts and axillaries smoky-brown like the breast; quills blackish below, slightly more ashy on the inner web. Total length about 7.5 inches; culmen, 0.7 ; wing, 5.8 ; tail, 2.7 ; central rectrices, 2.55 ; tarsus, 0.9 ; middle toe and claw, 0.9 .

Adult male. Similar to the female. Total length, about 7.5 inches; wing, 6.1.

Nestlings (Desertas: Padre Schmitz). Covered with long woolly down of a sooty-brown colour.

The male described is from Villa Island, Santa Maria, Azores, and was presented to the British Museum by Don J. S. G. de Camara. The female was procured on the Desertas by Padre Schmitz. The specimen figured is a St. Helena bird in our collection. 


\title{
9. OCEANODROMA MACRODACTYLA, Bryant.
}

\author{
(GUADALUPE FORK-TAILED PETREL.)
}

(Plate 5A.)

Oceanodroma leucorrhoa (nec Vieill.), Bryant, Bull. Calif. Acad., II., p. 276 (1887).

Oceanodroma leucorrhoa macrodactyla, Bryant, Bull. Calif. Acad., II., p. 450 (1887) ; id. Pr. Calif. Acad., II., p. 252 (1889).

Oceanodroma macrodactyla, A. O. U. Checkl. N. Amer. Birds, 1889, p. 5, No. 106 ;

Salvin, Cat. Birds Brit. Mus., XXV., p. 351 (1896); Oates, Cat. Eggs Brit.

Mus., I., p. 149 (1901) ; Godman, Biol. Centr.-Amer., Aves, III., p. 430 (1904).

O. castro similis, sed valde major, supracaudalibus late nigro terminatis, pedibusque fortioribus distinguenda.

THE larger size of $O$. macrodactyla distinguishes the species from $O$. castro, which it otherwise closely resembles. As in the latter the white upper tail-coverts are broadly tipped with black, but the wing-patch is somewhat paler, being of a light chocolate brown and of a less ashy-grey tint ; the light patch occupies the median and minor wingcoverts and extends to the long inner secondaries.

I have examined two specimens in the British Museum and three in the collection of the Hon. Walter Rothschild. The wing measures from 6.3-6.6 inches in the males, and in the females from 6.5-6.7 inches. The length of the middle toe and claw is from 1.05-1.1 inch, and of the tarsus 1.2-1.25 inch. The foot is decidedly larger than that of $O$. castro, the tarsus in the latter species being $0.9-0.95 \mathrm{inch}$, and the middle toe and claw $0.9-1.0$ inch.

This Storm-Petrel seems to be restricted in its range to the vicinity of the island of Guadalupe, off the coast of Southern California.

Eggs from this island, presented to the British Museum by Mr. Anthony, are white, marked at the larger end with minute spots of a faint reddish colour. Axis, 1.4-1.45 inch; diam., 1.1 .

Adult male. General colour above sooty-black, with a very distinct shade of plumbeous-grey; the scapulars and lesser wing-coverts black; the median and 


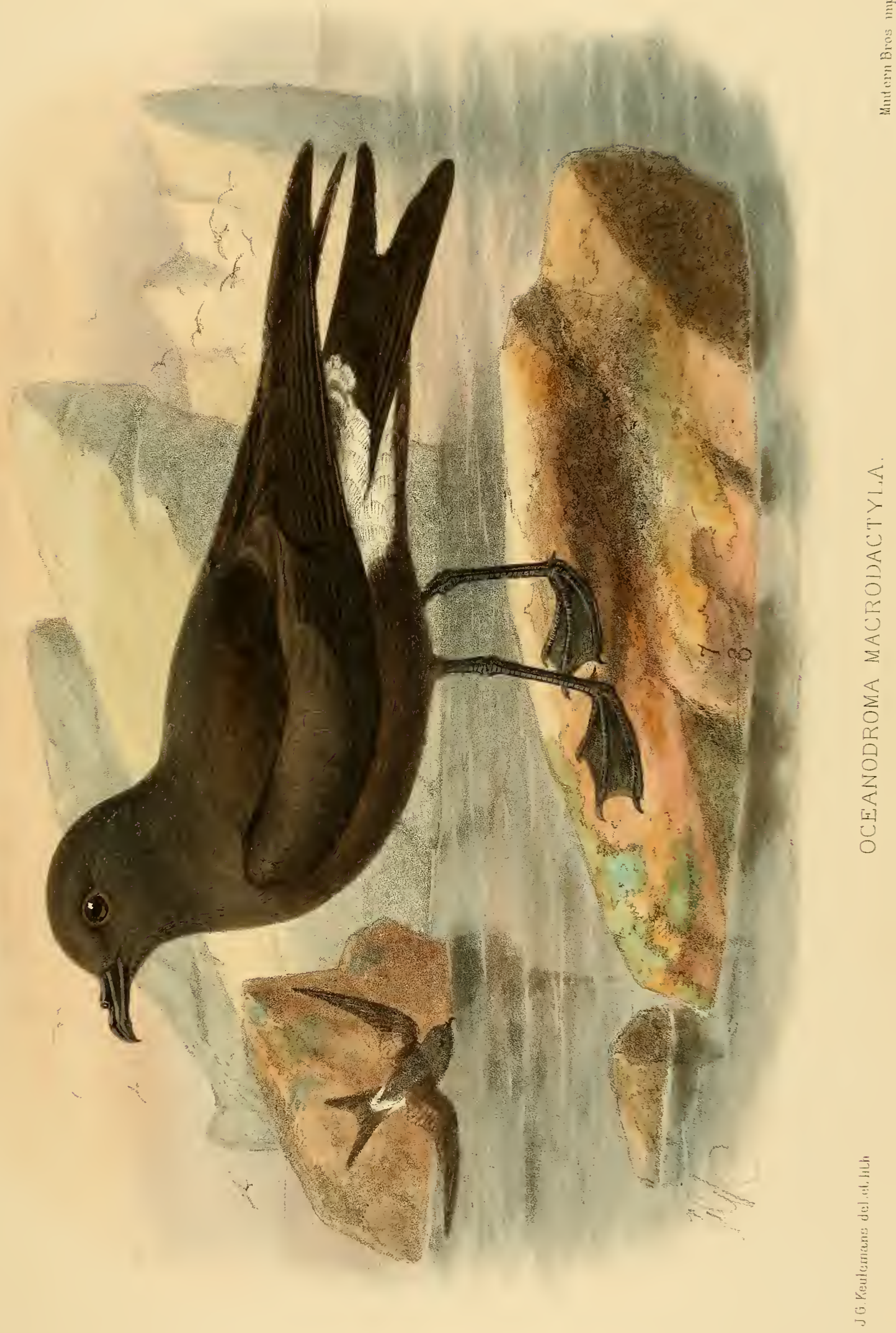





\section{OCEANODROMA MACRODACTYLA.}

greater series drab-brown; primary-coverts and quills black; the inner secondaries externally browner, and with hoary whitish edges; upper tail-coverts white, with broad black tips, the central coverts black, tipped with white; tail-feathers black, with a narrow white edging at the base of the outermost; head like the back, but a trifle more washed with slate-colour; in front of the eye a black shade; forehead, lores, and upper throat slightly browner; lower throat and sides of face plumbeous-grey; remainder of under-surface of body sooty chocolate-brown; at the sides of the vent a patch of white feathers, some of them more or less broadly edged with brown; under tailcoverts sooty-brown, the lateral ones mixed brown and white, like the flank-patch; under wing-coverts and axillaries sooty brown, the primary-coverts and quill-lining ashy-blackish; bill and feet black. Total length, 8.3 inches ; culmen, 0.6 ; wing, 6.3 ; tail, 3.6 ; central tail-feathers, 2.5 ; tarsus, 0.95 ; middle toe and claw, 1.05 .

Adult female. Similar to the male. Total length, 9.3 inches ; wing, 6.7.

The descriptions are taken from a pair of birds procured by Mr. Anthony, and now in the British Museum collection. From one of these birds the figure has been drawn. 


\section{OCEANODROMA TRISTRAMI, Stejneger.}

\section{(TRISTRAM'S FORK-TAILED PETREL.)}

Procellaria melania (nec Bp.), Seebohm, Birds Japan. Emp., p. 270 (1890).

Oceanodroma markhami (nec Salvin), Stejneger, Pr. U. S. Nat. Mus., XVI., p. 621 (1893).

Oceanodroma fuliginosa (nec Gm.), Stejneger, Pr. U. S. Nat. Mus., XVI., p. 620 (1893);

Salvin, Cat. Birds Brit. Mus., XXV., p. 352 (1896) ; Rothsch., Avif. Laysan, III., p. 308 (1896).

Oceanodroma tristrami, Stejneger in Salvin's Cat. Birds Brit. Mus., XXV., p. 354 (1896).

Major: uropygio et supracaudalibus fumoso-brunneis, minime albis: subalaribus fumoso-brunneis, pectore concoloribus, minime albicantibus.

A Petrel obtained by Mr. Y. Tanaka at Torishima in 1891, and presented by him to the Science College Museum at Tokyo, was described by Dr. Stejneger in the "Proceedings of the U.S. National Museum for 1893 " (Vol. XVI., p. 620). He identified the specimen with the "Sooty Petrel" of Latham (Gen. Syn., III., p. 409, undè Procellaria fuliginosa of Gmelin), and Salvin agreed with this identification.

Dr. Stejneger did not give the dimensions of his specimen, but he stated that it was " chiefly distinguishable from the other brown-rumped species by its larger size."

Mr. Seebohm considered that a Petrel from Sendai Bay, on the east coast of Hondo, obtained by Lieut. Gunn, and then in Canon Tristram's collection, was referable to $O$. melania, Bp., and on comparing it with the type of the latter species in Paris, he came to the conclusion that it was $O$. melania. Canon Tristram, however, sent the bird to Dr. Stejneger, who found that it was not identical with an example of 0 . melania obtained by Xantus at Cape St. Lucas. Dr. Stejneger further suggested that it might be $O$. markhami of Salvin, but subsequently he attached to it the name of $O$. tristrami, and under that title it was published by Salvin in the Catalogue of Birds of the British Museum. Personally, I think that Dr. Stejneger's conclusions were correct, and that the Japanese bird was certainly not $O$. melania. He refers to a table of measurements of $O$. tristrami and its allies, but this was not included in his memoir.

I have recently examined a Japanese specimen of the bird recognised by Dr. Stejneger as Latham's “Sooty Petrel," obtained by Mr. Alan Owston, on May 5th, 


\section{OCEANODROMA TRISTRAMI.}

1903, from Okinose, in the Sagami Sea, and lent me by Count von Berlepsch. Large in size, and dark in colour, it measures as follows:-Total length, 9.5 inches; culmen, 0.7 ; wing, 7.2 ; tarsus, 1.1 ; middle toe and claw, 1.15. The British Museum possesses another specimen, procured by Mr. Owston on the 19th of June, 1899, from the Uraga Channel, and identified by him as $O$. tristrami. It is not so dark as the Okinose example, and has a distinct plumbeous shade on the uppersurface, with faintly indicated whitish margins on the edges of the scapulars. These margins are, doubtless, signs of immaturity. The measurements are:-Total length, 8.75 inches; wing (worn), 6.85 ; tail, 3.3 ; tarsus, 1.1 ; middle toe and claw, 1.15 .

Although this specimen of $O$. tristrami is a little smaller than the so-called $O$. fuliginosa of Count von Berlepsch's collection, I believe the two birds to belong to one and the same species, the variation in measurements not being greater than is customary in the Storm-Petrels.

The Sendai Bay specimen, which was the type of 0 . tristrami of Stejneger, appears to have unfortunately been lost. At the time of the purchase of Canon Tristram's collection by the Liverpool Museum it was missing, and Dr. H. O. Forbes informs me that it was marked in Tristram's Catalogue as one of the species which he had lent, and would send to the Liverpool Museum in due course, but the specimen has never reached its destination. In 1896, when Salvin wrote the account of the Tubinares for the "Catalogue of Birds," the type of O. tristrami was still in America, as Mr. Ridgway sent him a detailed description of the specimen for publication in that volume (cf. Cat. Birds Brit. Mus., XXV., p. 354).

Dr. Stejneger, to whom I wrote on the subject, kindly informs me that the type was returned to Canon Tristram immediately after description, and it would seem, therefore, to have been lost on the way. Salvin was, in consequence, unable to figure the specimen for his proposed monograph; and in writing my account of the species, $I$ have been at a disadvantage in not having the actual type of $O$. tristrami before me, though there can be no doubt that the specimen from the Uraga Channel in the British Museum is identical with the bird described by Dr. Stejneger.

The original "Sooty Petrel" came from Otaheite, and was in the collection of Sir Joseph Banks. The type-specimen has, unfortunately, not survived, and thus we have only Latham's description to go upon, which reads as follows:- "Length, 11 inches; bill black, one inch long, and hooked at the tip ; irides pale ash-colour; head and neck of a sooty black; the body in general tinged with brown, not unlike the colour of the Swift. The rump is brown; the under part of the body much like the upper, but paler; the ridge of the wing mixed with ash-colour; the tail is somewhat forked in shape, but the feathers themselves are square at the ends-their colour, and that of the quills, a deep black; the wings when closed exceed the tail a trifle in length. Legs slender, an inch long and black. Inhabits Otaheite. In the collection of Sir Joseph Banks." Then follows a footnote :- "In a drawing in the possession of the same, 


\section{MONOGRAPH OF THE PETRELS.}

each web of the toes was marked with a yellow spot." This footnote in Latham's work does not help us to identify the Sooty Petrel, for the description states that the "leg is slender, an inch long, and black." It may, therefore, be taken for granted that the original specimen had no yellow spot on the interdigital webs. It follows that Latham must have made a mistake in referring the sketches in the Banksian collection to his Sooty Petrel. On consulting the "Drawings" in the British Museum, I find that the birds referred to by Latham must be Nos. 12 and 13 of Sydney Parkinson's sketches (cf. Sharpe, Hist. Coll. Brit. Mus., II., pp. 174, 175). These plates represent two distinct species of Petrel, No. 12 being Oceanitis oceanica, which Kuhl, the first describer of the species, refers to as Procellaria oceanica of Banks' MSS. No. 13 is an unfinished coloured drawing of Pelagodroma marina (Lath.). These identifications were made by Salvin, and confirmed by Dr. Bowdler Sharpe (l.c.). In each case a MSS. note by Parkinson alludes to the yellow on the interdigital web, and we do not find any other picture in Forster's or Ellis's drawings in the Banksian Library in which this character is portrayed. Latham evidently confused three species together, and his "Sooty Petrel" is not yet satisfactorily determined, as the description and measurements do not entirely suit the Japanese birds examined by me.

Under these circumstances I think it best to drop the name of $O$. fuliginosa and take that of $O$. tristrami for the Black Fork-tailed Petrel of Japan.

Until recently, O. tristrami had only been found off the coasts of Japan in summer, but Mr. Walter K. Fisher records it as nesting in some numbers on Laysan Island during our winter months $(A u k, 1903$, p. 386). It may, therefore, breed on these islands and migrate north at other seasons of the year.

The Hon. Walter Rothschild, in his "Avifauna of Laysan," like myself, doubts whether the name of Oceanodroma fuliginosa can rightly be adopted for the bird which is now known to occur in the seas of Japan, and to extend to the island of Laysan. I reproduce Mr. Rothschild's remarks (Avif. Laysan, III., p. 308) :-

" Professor Schauinsland did not meet with this Petrel alive when on Laysan, but from the examination of some fragments of skeletons which he has picked up, he concluded that another, hitherto unrecorded, species of Petrel, with one nostril-opening, must occur there. This is, in fact, the case, for months after he had left, a new species arrived in small numbers, and bred, like the others, in holes. One skin was sent to the Bremen Museum, and determined by Professor Reichenow as Oceanodroma fuliginosa. I am obliged to Professor Schauinsland for having lent me this example for description. There seems to be no doubt that this bird is the same as that called $O$. fuliginosa by Dr. Stejneger, and also in the 'Catalogue of Birds' (Vol. XXV.). Another question is, whether there is sufficient reason to refer it to Latham's 'Sooty Petrel,' and consequently to adopt Gmelin's name. The original description would suit many dark brown species of approximately the same size, and is evidently equally well applicable to Bulveria anjinho, or more still to B. macgillivrayi from Fiji, and Cymo- 


\section{OCEANODROMA TRISTRAMI.}

droma mastissima from Samoa. As Latham's bird was from Otaheite, it is necessary for us to receive so-called $O$. fuliginosa from there, to prove beyond doubt that the birds from the Japanese seas and Laysan are really rightly called $O$. fuliginosa. In Latham's description the slaty colour of the upper side is not mentioned, the brown rump is not marked in the modern bird, and the under side is brown (not slaty), but not paler than the upper side! The example from Laysan measures:-Wing, 7.3 inches; tail, 4.1 ; forked for 1.25 ; culmen (over curve), 0.8 ; bill from gape, 1.1 ; metatarsus, 1.15 ; middle toe and claw, 1.15. Nasal tube rather prominent. (Sex not determined on label.)"

Adult male. Above sooty-black, with a distinct gloss of plumbeous-grey; scapulars black, with a whitish edging at the tip; marginal wing-coverts black, the remainder of the coverts drab-brown; the inner secondaries similarly coloured but paler, the innermost black; primary-coverts and quills black; lower back and rump slightly greyer than the back; upper tail-coverts black, ashy-brown for the basal half ; tail-feathers black; head, neck and throat lighter plumbeous-grey ; the remainder of under-surface, including the under wing-coverts and axillaries, sooty-brown; under tail-coverts like the abdomen; primary-coverts and inner aspect of quills dusky-grey. Total length, 8.7 inches ; culmen, 0.7 ; wing, 6.8 ; tail, 3.7 ; median tail feathers, 2.2 ; tarsus, 1.8 ; middle toe and claw, 1.1.

The description is taken from the specimen from the Uraga Channel referred to above, procured by Mr. Alan Owston on the 19th June, 1899. As O. markhami is figured on Plate 7 , and the colours of that species and $O$. tristrami are exactly the same, it has not been considered necessary to give a coloured illustration of the latter bird. 


\title{
11. OCEANODROMA MELANIA $(B p$.
}

\author{
(BLACK FORK-TAILED PETREL.)
}

(Plate 6.)

Procellaria melania, Bp., C. R., XXXVIII., p. 662 (1854).

Thalassidroma melania, Bp., Consp. Av., II., p. 196 (1856).

Cymochorea melania, Coues, Pr. Acad. Philad., 1864, p. 76; Baird, Brewer, and

Ridgw., Water Birds N. Amer., II., p. 411 (1884).

Cymochorea meloena, Nelson, Cruise "Corwin," p. 113 (1883).

Oceanodroma melania, Cooper, Auk, 1887, p. 87 ; Salvin, Cat. Birds Brit. Mus., XXV., p. 353 (1896); Oates, Cat. Eggs Brit. Mus., I., p. 149, Pl. XI., Fig. 3 (1901); Grinnell and Daggett, Auk, 1903, p. 10 ; Godman, Biol. Centr.-Amer., Aves, III., p. 430 (1904).

Oceanodroma townsendi, Ridgway, Pr. U. S. Nat. Mus., XVI., p. 687 (1893).

Major: fuliginoso-nigra, vix schistaceo adumbrata: supracaudalibus dorso concoloribus, minime albis: tectricibus alarum medianis et majoribus pallidioribus brunnescentibus, augustissime albido marginatis.

THIS species was first described by Bonaparte from a single specimen obtained by Delattre on his voyage from Nicaragua to California, but the exact locality was not recorded. The typical example is in the Paris Museum, and was re-described by Salvin in the "Catalogue of Birds." He gives the measurements as follows:- Total length (skin) about 10 inches ; wing, 7.50 ; tail, 4.45 ; forked for 1.60 ; culmen, 0.70 ; depth of bill just before nasal tubes, 0.25 ; tarsus, 1.1 ; middle toe, 1.1 (l.c., p. 353).

In 1864 Coues identified a specimen from Cape St. Lucas, collected by Xantus as being Bonaparte's $O$. melania, and in this he was undoubtedly right. Since that time many examples have been obtained, and the species is now sufficiently well known.

This is one of the largest of the Fork-tailed Petrels, and is nearly uniform black in colour, with the exception of the usual light wing-patch which is characteristic of the species of Oceanodroma. It is distinguished from $O$. tristrami and $O$. markhami 


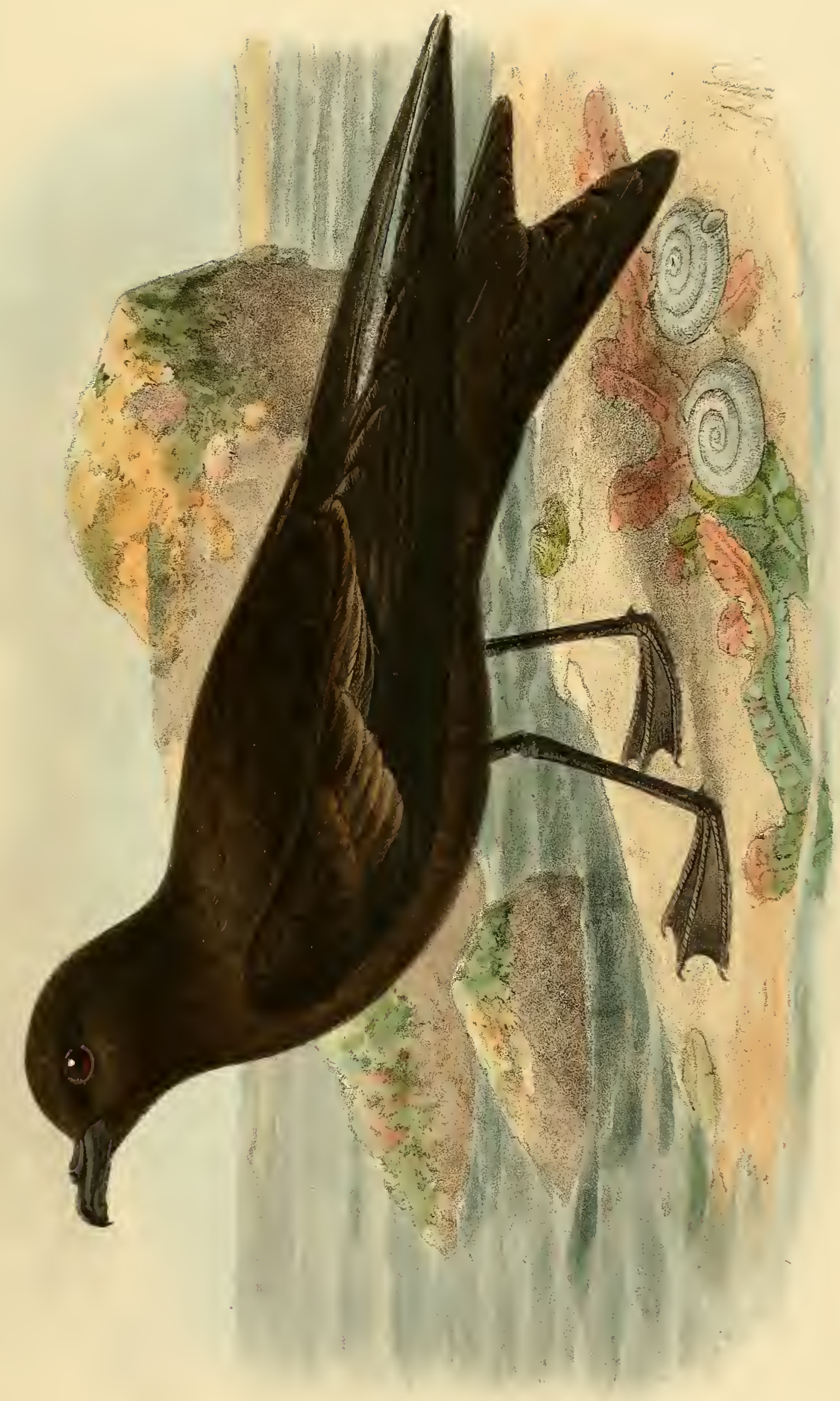





\section{OCEANODROMA MELANIA.}

by its shorter and thicker bill, and from $O$. monorhis and $O$. homochroa by its larger size.

A comparison of the measurements of $O$. melania and $O$. monorhis is given under the heading of the latter species.

O. melania has been chiefly found among the islands off Lower California. Thus, in addition to the specimens procured by the late John Xantus off Cape St. Lucas, it has been recorded by Dr. J. G. Cooper from the vicinity of the Santa Barbara Islands ( $A u k, 1887$, p. 87). On the Coronado Islands it has been found nesting sparingly on North and Middle Islands by Messrs. Grinnell and Daggett (Auk, 1903, p. 31), and by Mr. Anthony on the San Benito Islands (Condor, II., p. 28).

Dr. C. H. Townsend met with this Storm-Petrel off Acapulco, Western Mexico; and Mr. Nelson recorded it as common, together with other small black Petrels, between Isabel Island and the Tres Marias group. Mr. W. W. Bailey observed it plentifully between the coast of Mexico and the Tres Marias. Although he found no eggs when visiting the last-named islands in June, 1905, he received information which induced him to believe that these birds bred on the lower end of Maria Cleofa, and on White Rock later in the season ( $A u k, 1906, \mathrm{p} .378)$.

Mr. Nelson, in his account of the voyage of the "Corwin" (p. 113), records O. melania from more northern latitudes than have hitherto been considered to form its habitat. He writes :- "As we left the Aleutian Islands on our way to San Francisco in October, and thence on for several hundred miles, a large black Petrel was repeatedly seen. The size of this bird would indicate that it was the species mentioned above, though no specimen was secured. It was repeatedly noticed along with Leach's Petrel and the Fork-tailed Petrel, and thus excellent opportunities were afforded for judging its relative size." Mr. Nelson, not having obtained a specimen, the identification of the species must remain in abeyance, but I am inclined to think that it would have been $O$. tristrami (the so-called $O$. fuliginosa) rather than $O$. melania, which occurred so far north.

On San Benito Island Mr. Anthony found both O. melania and O. socorroensis breeding, but the latter had young birds when $O$. melania had only eggs in the nest (Condor, II., p. 28).

Eggs presented by Mr. A. W. Anthony from San Benito Island are in the British Museum collection. They are pure white, with scarcely a trace of any reddish speckling. Axis, 1.4 inch; diam., 1.05 .

Adult male. General colour sooty-black, with a light shade of plumbeous-grey; wing-coverts and scapulars black, the latter edged at the tip with whity-brown; lesser and median wing-coverts black, paler brown externally, edged with whity-brown; primary-coverts and quills black; tail-feathers black; head and neck, as well as the throat, sooty-black, with a more distinct shade of plumbeous; rest of under-surface of body sooty chocolate-brown, including the under tail-coverts and under wing-coverts 


\section{MONOGRAPH OF THE PETRELS.}

and axillaries, the latter having a slight tinge of rust colour ; lower greater coverts and quill-lining blackish, the latter somewhat ashy-grey; bill and feet black. Total length, 8.4 inches ; culmen, 0.5 ; wing, 6.8 ; tail, 3.3 ; tarsus, 1.2 .

Adult female. Similar to the male. Total length, 8.5 inches; wing, 7.0 ; tarsus, 1.2.

The figure in the Plate is drawn from the original type in the Paris Museum, and was kindly lent to Salvin by the authorities of that institution. The descriptions of the birds are taken from a pair from San Benito Island, presented to the British Museum by Mr. A. W. Anthony. 



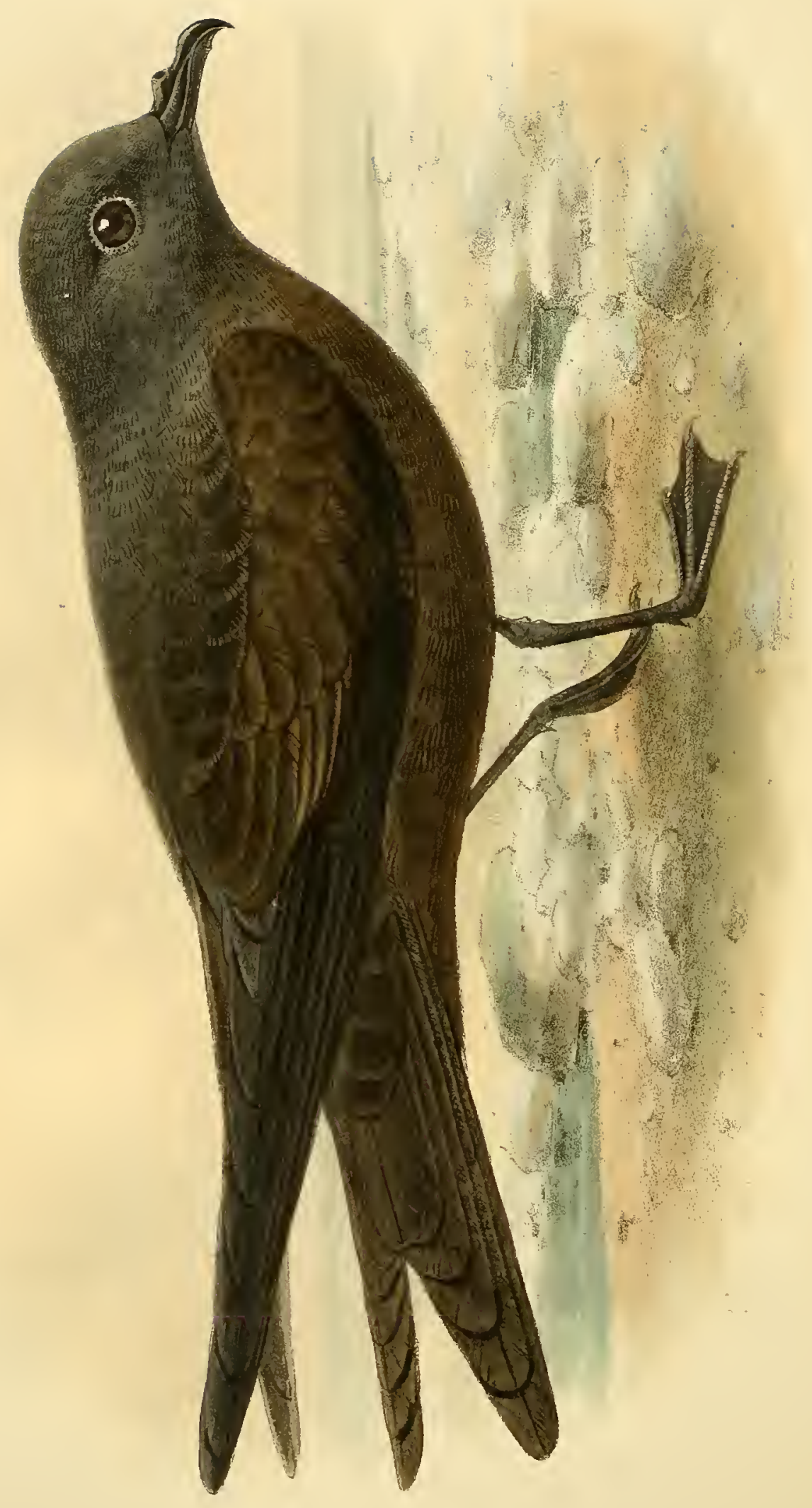

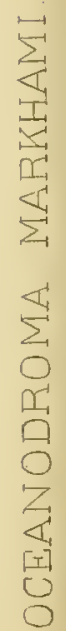




\title{
12. OCEANODROMA MARKHAMI (Salvin).
}

\author{
(MARKHAM'S FORK-TAILED PETREL.)
}

(Plate 7.)

Cymochorea markhami, Salvin, P. Z. S., 1883, p. 432 ; Tacz., Orn. Pérou, III., p. 462 (1886).

Oceanodroma markhami, Ridgway, Man. N. Amer. Birds, p. 71 (1887); Salvin, Cat. Birds Brit. Mus., XXV., p. 354 (1896).

O. tristrami similis, vix minor, sed tarso et digitis gracilioribus, debilioribus distinguenda.

THIs species is founded upon two female birds procured by Admiral A. $H$. Markham, off the coast of Peru, one in Lat. $10^{\circ} 40^{\prime} \mathrm{S}$., Long. $75^{\circ} \mathrm{W}$., the other in Lat. $23^{\circ} \mathrm{S}$., Long. $73^{\circ} \mathrm{W}$. Both of these specimens have passed from our collection into that of the British Museum.

The late Osbert Salvin, who described the species, considered that it was separable from $O$. tristrami by reason of the shorter tarsus ( $1 \mathrm{in}$.), middle toe and claw (1.15 in.), and the distinctly plumbeous head and mantle. In $O$. tristrami the head and mantle are darker, and the tarsus and toes are decidedly longer and more robust. The plumbeous or slaty shade which is seen in many of the Fork-tailed Petrels seems to me merely indicative of freshly moulted, or breeding, plumage; it disappears as the feathers become worn, and is by no means. a character for the separation of one species of Oceanodroma from another.

Both $O$. tristrami and $O$. markhami have much more slender bills than $O$. melania, the culmen of the first two measuring $0.7 \mathrm{inch}$, while that of 0 . melania is only $0.6 \mathrm{inch}$, and the bill is shorter and stouter. In plumage these three species resemble each other.

The two specimens of 0 . tristrami examined by me (vide antea, p. 20) gave the following measurements:-Wing, 6.8-7.2 inches; tarsus, 1.1-1.15; middle toe and claw, 1.1-1.15. 


\section{MONOGRAPH OF THE PETRELS.}

In the type-specimens of 0 . markhami the dimensions are as follows:-Total length about 9.0 inches ; culmen, 0.7 ; wing, 6.9 ; tail, 3.7 ; central rectrices, 2.4 ; tarsus, 0.95 ; middle toe and claw, 0.95 .

It cannot, therefore, be doubted that $O$. markhami is a small form of $O$. tristrami, with a more slender foot; but the number of specimens examined has been so few that intermediate examples may yet be discovered, and the identity of the two species be proved. It would not be surprising to learn that a species of Petrel which summers in Japan should be found in winter off the coasts of Peru.

Of the habits of $O$. markhami nothing is known, and the only examples as yet recorded are the two type-specimens in the British Museum, one of which has been figured in the Plate. 



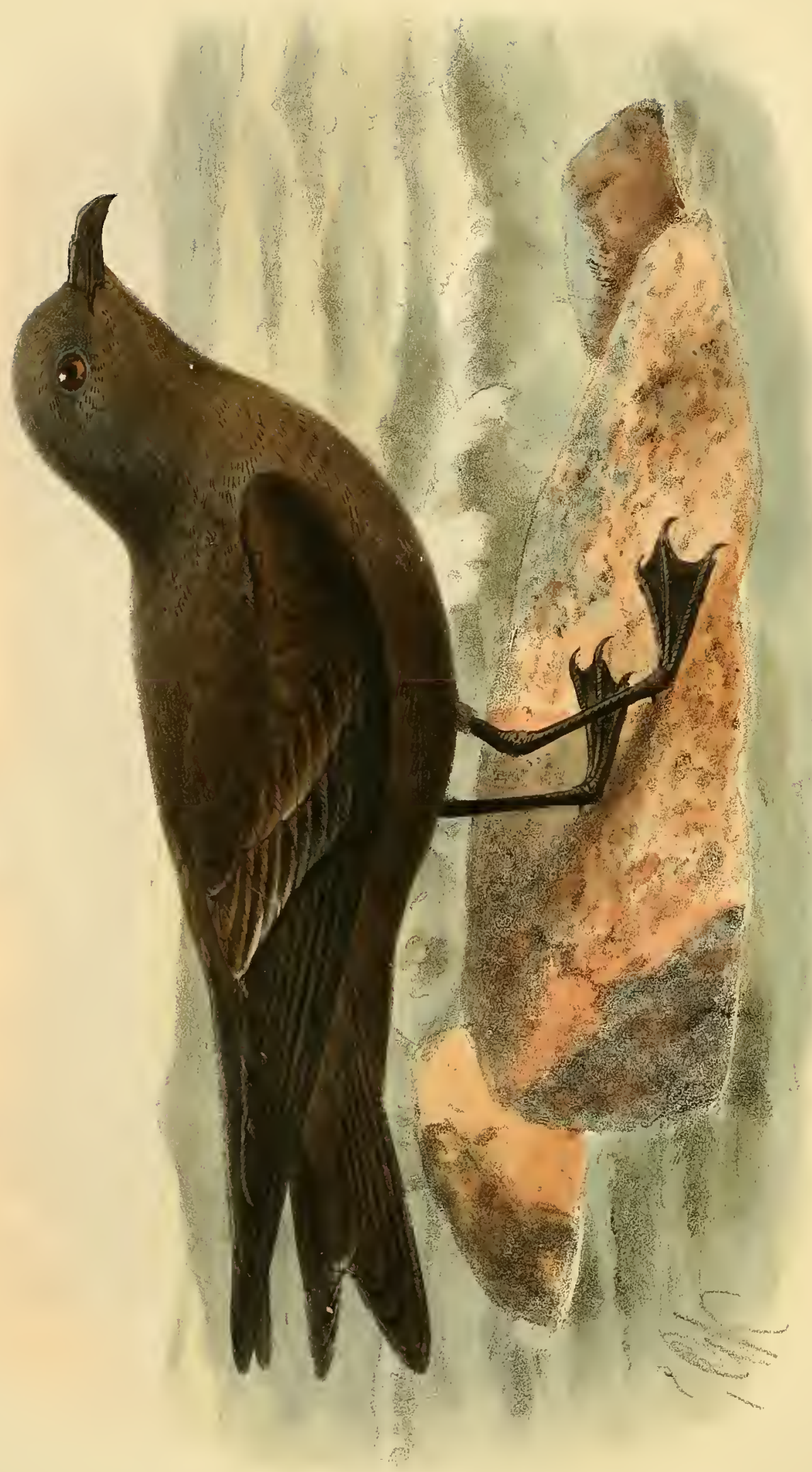




\section{OCEANODROMA HOMOCHROA (Coues).}

\section{(ASHY PETREL.)}

(Plate 8.)

Thalassidroma melania (nec Bp.), Lawr. in Baird, Cassin and Lawr., Birds N. Amer., p. 830 (1858).

Cymochorea homochroa, Coues, Pr. Acad. Philad., 1864, pp. 72, 77, 91, 114, 116 ; Baird, Brewer and Ridgway, Water Birds N. Amer., II., p. 411 (1884).

Procellaria homochroa, Gray, Handl. Birds, III., p. 104, No. 10,858 (1871).

Oceanodroma homochroa, Ridgway, Pr. U. S. Nat. Mus., VIII., p. 356 (1885) ; Salvin, Cat. Birds Brit. Mus., XXV., p. 355 (1896); Godman, Biol. Centr.-Amer., Aves, III., p. 429 (1904).

$O$. melanice similis, sed minor et conspicue schistaceo adumbrata; plaga alari pallida, magis cinerascente, tectricibus majoribus extus albido fimbriatis : gastræo toto schistaceo-fuliginoso, tectricibus subalaribus majoribus cinerascentialbido externe lavatis.

THIS is the smallest of the brown-rumped group of the genus Oceanodroma. It is rather more ashy-grey than the other species, and resembles $O$. monorhis in general appearance, but is distinguished by its smaller size, and by the hoary-white shade on the greater under wing-coverts. In all the allied species these coverts are smoky-brown without any grey gloss. The bill is shorter and stouter in 0 . homochroa. The amount of grey on the under-surface of the body varies somewhat, some birds being blacker than others. The wing-patch is not very distinct, but some specimens have greyishwhite edgings to the greater upper wing-coverts. This may be a sign of immaturity.

The following are the dimensions of the five specimens examined by me:-

\begin{tabular}{|c|c|c|c|c|c|}
\hline & & & Wing. & Tarsus. & $\begin{array}{l}\text { Middle toe } \\
\text { and claw. }\end{array}$ \\
\hline ¿ Farallon Is. (Mus. Rothschild) & & . & 5.65 & 0.95 & 0.95 \\
\hline Do. & - & . & 5.5 & 0.9 & 0.9 \\
\hline Ad. San Miguel Isl. (Henshaw Coll. & Mus. & Brit.) & 5.4 & 0.9 & 0.9 \\
\hline$ð$ Point Reyes (Mus. Brit.) & . & . & 5.1 & defective. & \\
\hline Do. & . & . & 5.5 & 0.9 & 0.9 \\
\hline
\end{tabular}




\section{MONOGRAPH OF THE PETRELS.}

The present species was described by the late Dr. Elliot Coues from a specimen from the Farallon Islands in the U.S. National Museum.

It was also supposed to occur off the coast of California, but at the date of Baird, Brewer, and Ridgway's "Water Birds," only one genuine capture had been recorded, viz., a specimen from San Miguel Island in the collection of Mr. H. W. Henshaw. This example, which is now in the British Museum, was given to Mr. Henshaw by Captain Forney, who stated that the species bred on San Miguel in great numbers. It is now known to breed on the Santa Barbara Islands and the Farallones (A. O. U. Checkl., 2nd Ed., p. 37, 1895).

In the last-named locality it has been observed nesting by Mr. Loomis (Pr. Calif. Acad. Sci. (2), VI., p. 361), and by Mr. Milton S. Ray (Auk, 1904, p. 436). The latter gentleman visited the islands early in June, 1904, but found only eggs of the previous year, as the birds had apparently not begun to lay at the time of his visit.

Mr. Ray writes:- "We saw little of these Petrels except at night, when they fluttered about, or on our daily rambles, when we spied their dark forms in some narrow crevice in the ledges or rock-fences. On being lifted in the hand, a dark oily fluid would drip from their beaks, and, when released, these birds, with the form and wavy flight of a Swallow, would make for the open sea. We noticed a number of these dainty little birds which had been killed by striking the telephone and telegraph wires on the island."

Mr. Loomis gives an interesting note of the nesting of the Ashy Petrels on South Farallon Island in July. The birds were active at night, but were not in evidence during the day, for the brooding birds were concealed in loose piles of stones, in stone walls, and under driftwood. The flight resembled that of a Goatsucker. Sometimes the Petrels' nests were within reach, but more often the rocks had to be removed to get at them. When uncovered, they generally shrank away as far as they could, but occasionally one would remain on the eggs. When tossed into the air, they flew without difficulty (cf. Loomis, l.c., p. 262).

Adult male. General colour above sooty-black, with a distinct plumbeous gloss; head like the back; under-surface of body somewhat paler and more sooty-brown; the throat decidedly plumbeous-grey; lesser and median wing-coverts black, the greater series externally ashy-brown, forming an inconspicuous wing-patch; primary-coverts and quills black, the innermost secondaries paler, and externally ashy-brown like the greater coverts; tail-feathers black; under wing-coverts sooty-brown, slightly darker than the breast, the median series shaded with hoary-white; quills dusky black below ; the greater coverts and quill-lining somewhat inclining to ashy-black. Total length, about 7.6 inches ; culmen, 0.6 ; wing, 5.1 ; tail, 3.0 ; central rectrices, 2.1.

Adult female. Similar to the male, but with the hoary-white edgings to the greater wing-coverts more distinct, but the greyish shade on the under wing-coverts not so pronounced. Wing, 5.5 inches; tarsus, 0.85 ; middle toe and claw, 0.95 . The female was killed on the 22nd April, and the male on the 10th July, and the former is 


\section{OCEANODROMA HOMOCHROA.}

therefore in less worn plumage, which may account for the greater amount of hoarywhite on the greater wing-coverts.

The specimen from San Miguel Island in the Henshaw Collection is in faded plumage, and is of a more chocolate-brown throughout.

The descriptions of the male and female are taken from a pair of birds received by Mr. C. K. Worthen from Point Reyes, California, in our own collection. The specimen figured is the one from San Miguel Island, also in our collection, and now in the British Museum. 


\section{OCEANODROMA MONORHIS (Swinhoe).}

(SWINHOE'S FORK-TAILED PETREL.)

(Plate 9.)

Thalassidroma monorhis, Swinhoe, Ibis, 1867, p. 386.

Procellaria monorhis, Gray, Handl. Birds, III., p. 104, No. 10,855 (1871).

Oceanodroma monorhis, Salvin, Cat. Birds Brit. Mus., XXV., p. 121, PI. II. (1896).

Oceanodroma socorroensis, C. H. Townsend, Pr. U. S. Nat. Mus., XIII., p. 134 (1890); Salvin, Cat. Birds Brit. Mus., XXV., p. 352 (1896); Anthony, Auk, 1896, p. 387, 1898, p. 38 ; Oates, Cat. Eggs Brit. Mus., I., p. 149, Pl. XI., Fig. 6 (1899); Grinnell and Daggett, Auk, 1903, p. 31 ; Godman, Biol. Centr.-Amer., Aves, III., p. 431 (1904).

Oceanodroma townsendi (nec Ridgway), Anthony, Auk, 1904, p. 321.

Oceanodroma monorhis chapmani, Berlepsch, Auk, 1906, p. 185.

O. melania similis, sed minor : pileo et corpore autico magis plumbescentibus.

The Storm-Petrel hitherto known as $O$. socorroensis is a small form of $O$. melania, and it is somewhat remarkable that the two races should be found inhabiting the same localities, both breeding on the San Benito and Coronado Islands. There is scarcely any difference beyond that of measurements between $O$. melania and $O$. socorroensis, but the latter is perhaps imbued with a more plumbeous shade on the head, neck, and forepart of the body, the face and throat being also plumbeous. O. melania, on the other hand, is a very black bird, and is decidedly larger than $O$. socorroensis, as the measurements show.

The series of $O$. melania examined by me gives the following results:--

$\begin{array}{lll}\text { Wing. } & \text { Tarsus. } & \text { Middle to } \\ \text { and claw. }\end{array}$

$\begin{array}{llllllll}\text { a. b. ¿San Benito IsI. (Mus. Rothschild) } \quad \ldots & 6.7-7.0 & \ldots & 1.15-1.2 & \ldots & 1.2\end{array}$

$\begin{array}{llllllllll}\text { c.d. } q \text { Do. do. } & \text { d } & 6.9-7.2 & \ldots & 1.15-1.2 & \ldots & 1.2\end{array}$

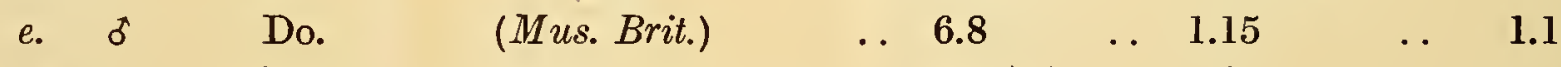

$\begin{array}{llllllllll}\text { f.g. } q \text { Do. } & \text { do. } & \text { D } & 6.9-7.0 & \ldots & 1.2 & & \ldots & 1.1\end{array}$ 


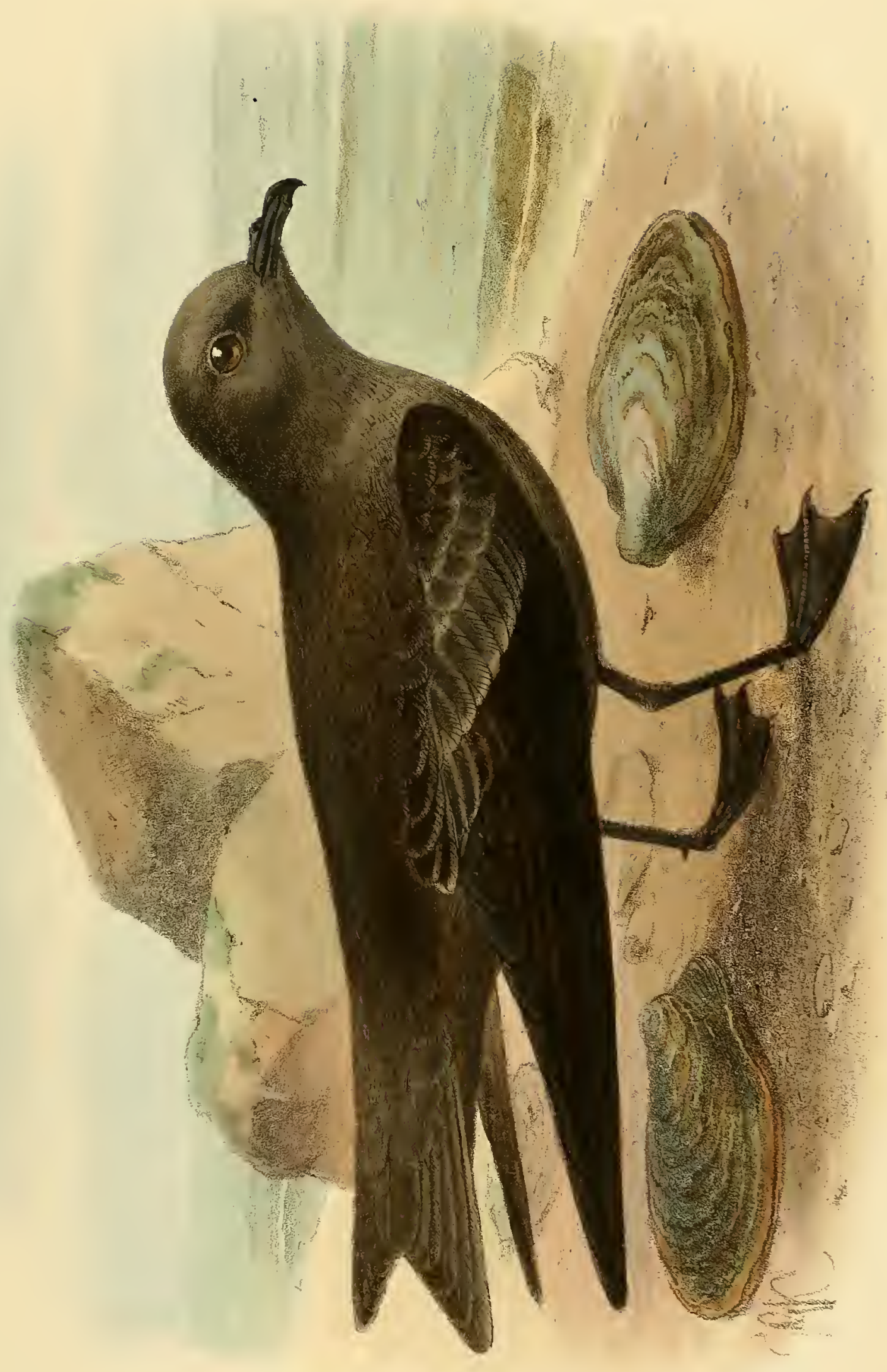

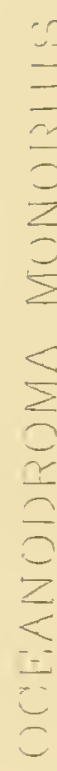





\section{OCEANODROMA MONORHIS.}

The specimens of $O$. socorroensis in the British Museum and in the Rothschild collection measure :-

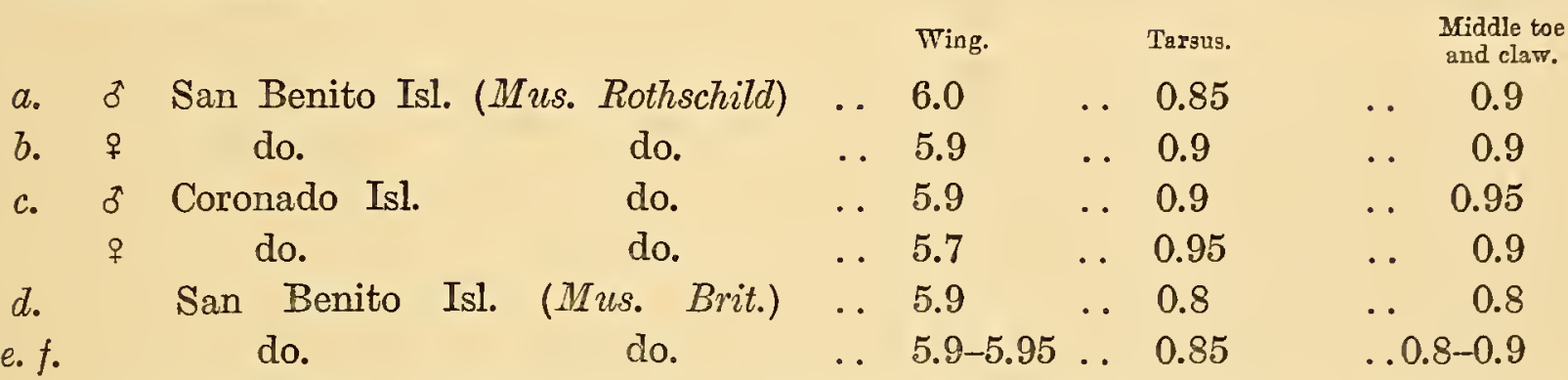

It will, therefore, be seen that $O$. socorroensis is a smaller bird than 0 . melania, the wing not exceeding 6 inches in length, and the tarsus and middle toe not exceeding 0.95 inches. According to Mr. Anthony O. melania also differs in its note, having a harsher cry than 0 . socorroensis.

It will be noticed that in the synonomy of this species $I$ have identified $O$. socorroensis with $O$. monorhis, of Swinhoe. I have compared examples from China with others from San Benito Island, and I fail to ind any specific characters for the separation of the two forms. The type of $O$. monorhis is rather lighter grey on the head and throat than most of the American specimens, but a bird procured by Mr. Rickett in the vicinity of Foochow appears to me to resemble the latter in every respect. The measurements of the series from the coasts of Eastern Asia are as follows:-

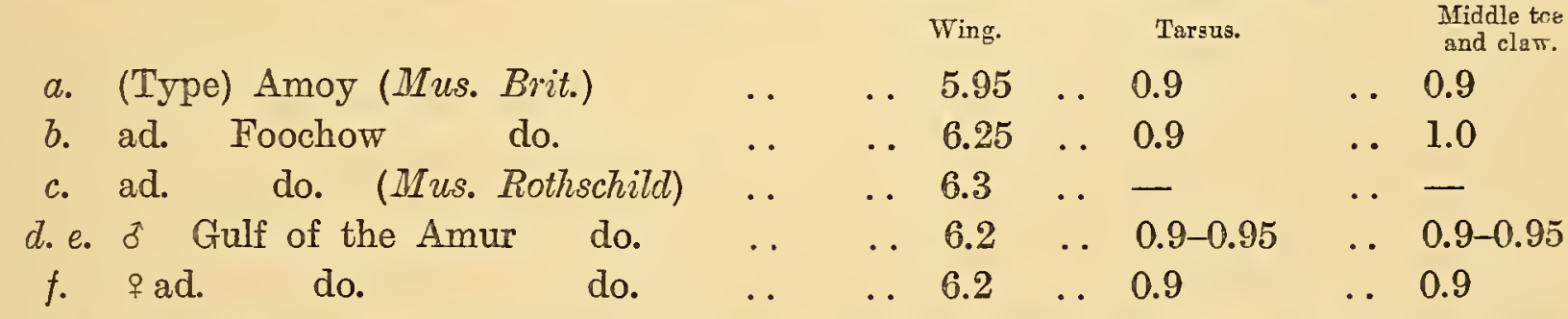

The specific name of monorhis is founded upon the misconception that in the typespecimen there was only one nasal opening, and that the nasal septum was wanting in the Chinese species. A close examination, however, reveals the fact that in Swinhoe's type-specimen the septum is present, but does not extend so far forward as in the other species of Oceanodroma. The nostrils appear to have been plugged by the taxidermist on skinning the bird, and the septum was thus partially obliterated. Dr. Stejneger also failed to find the single nasal opening in the specimen he examined from Japan (Pr. U. S. Nat. Mus., XVI., p. 622), and Mr. Rothschild's birds from the Bay of the Amur have also normal nostrils.

The identity of $O$. socorroensis with $O$. monorhis naturally increases the range of the species immensely.

Count von Berlepsch has very kindly sent me for examination the types of his o. monorhis chapmani which he described from the San Benito Islands. I find them 


\section{MONOGRAPH OF THE PETRELS.}

to be inseparable from our examples of 0 . socorroensis from the same locality. The dimensions of $O$. chapmani are as follows :-

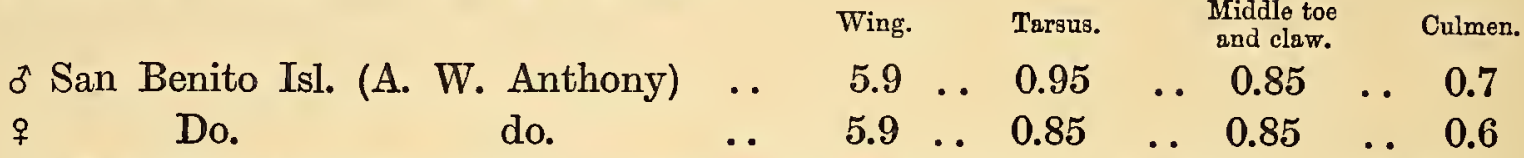

O. monorhis was discovered by the late Consul Swinhoe at Amoy. The typespecimen passed into the possession of Mr. Seebohm, and was by him bequeathed to the British Museum. Mr. C. B. Rickett obtained two specimens near Foochow in July, and the species ranges to Japan and Eastern Siberia. Mr. Rothschild's Museum contains three examples from the Gulf of the Amur, procured by the brothers Doerries, and Dr. Stejneger records the species from the province of Mutsu, in Japan (Pr.U.S. Nat. Mus., XVI., p. 622). He has included the species in his list of the birds of the Liu Kiu Islands on the authority of Swinhoe (P. Z. S., 1871, p. 422), who says that it had been found breeding there.

On the Pacific coast of America this Petrel was obtained by Dr. C. H. Townsend, on Socorro Island in the Revillagigedo group (Pr. U. S. Nat. Mus., XIII., p. 134), and Messrs. Grinnell and Daggett found it breeding plentifully on North and Middle Islands in the Coronado group $(A u k, 1903$, p. 31). Mr. Anthony records it as nesting on the San Benito Islands (Auk, 1894, p. 321). He states that it is much less numerous on these islands than $O$. melania, and that while the latter species had only eggs, $O$. socorroensis had young by the 5th of July, and were soon away in search of food, which, as far as he could discern, consisted of the young of the Rock-Lobster. It sometimes extends as far as the neighbourhood of San Diego, in California, where Mr. Anthony has recorded the occurrence of several specimens in May, 1895 (Auk, 1895, p. 387).

He also observes that the brown colour of the rump and upper tail-coverts, which is one of the characteristics of the species, is not constant, for occasionally the lateral upper tail-coverts are white, some examples having nearly as much white on the rump as in O. leucorrhoa. In his experience, about three per cent. of the specimens procured showed this white on the upper tail-coverts, and both white- and sooty-rumped birds were found in the same burrow. Messrs. Grinnell and Daggett noticed the same variation in the colour of the rump in specimens obtained on the Coronado Islands $(A u k, 1903$, p. 32).

According to the last-named observers, the situation of the nests varied considerably. Sometimes the burrows would be found in small accumulations of peat round the buckthorn bushes, at other times they lay between fragments of rock where the end would be impossible to reach. The shortest burrows would not exceed twelve inches in length, whilst the longest zigzagged to a distance of six feet. There was frequently no real construction, and a sparse flooring of fine twigs and grass sufficed for the purpose of nesting. Both male and female birds assisted at the incubation.

Two eggs in the British Museum from San Benito Island, presented by Mr. 


\section{OCEANODROMA MONORHIS.}

Anthony, are white, faintly speckled with reddish dots at the larger end, forming a cap in one of the eggs and a zone in the other. Axis, 1.2 inch; diam., 0.9 (cf. Oates, Cat. Eggs Brit. Mus., I., p. 149, Pl. XI., Fig. 6.)

Adult female (type of species). Above sooty-brown, with a slight plumbeous gloss ; rump and upper tail-coverts like the back; head and neck rather more plumbeous than the back; the forehead, sides of face and throat rather paler ashy-grey; remainder of under-surface, including the under wing-coverts, axillaries, and undertail-coverts, slightly paler than the upper-surface, and inclining to chocolate-brown; lesser upper wing-coverts sooty-black, like the scapulars and innermost secondaries, some of the latter fringed with hoary-white; median and greater coverts lighter and more ashy-brown, narrowly fringed with hoary-white; primary-coverts, quills, and tailfeathers black; "bill black; inside of mouth flesh-colour; tongue flat and broadly sagittate, furrowed down the middle and on either side; legs black; the inner side of the inner toe and both sides of the middle toe whitish near their bases " (R. Swinhoe). Total length, 7.5 inches; culmen 0.6 ; wing, 5.95; tail, 2.8 ; central rectrices, 2.2 ; tarsus, 0.9 ; middle toe and claw, 0.9 .

The description is taken from the typical specimen now in the British Museum, from which also the figure in the Plate has been drawn. 


\title{
15. OCEANODROMA HORNBYI (Gray).
}

\author{
(HORNBY'S FORK-TAILED PETREL.)
}

(Plate 10.)

Thalassidroma hornbyi, Gray, P. Z. S., 1853, p. 62; Lawrence in Baird, Cassin and Lawrence, Birds N. Amer., p. 829 (1863).

Oceanodroma hornbyi, Bp., Consp. Av., II., p. 195 (1856); Salvin, Cat. Birds Brit. Mus., XXV., p. 356 (1896).

Procellaria hornbyii, Gray, Handl. Birds, III., p. 105, No. 10,871 (1871).

Cinereus : pileo nigricante : subtus albus, fascia præpectorali lata schistacea.

THIS species is easily recognised by the dark collar across the fore-neck, the undersurface being otherwise pure white, and the back a dingy grey. It is only represented in museums by the single type-specimen in the National Collection, described by Mr. George Robert Gray. It was procured by Admiral Hornby when he was in command of the Pacific Station, and is said to have been obtained in the seas off the north-western coast of America. During the sixty years which have elapsed since its original discovery, no second specimen has been obtained, and in the "Check-list" of North American Birds, it is placed in the "Hypothetical List" as if the correctness of the habitat were not credited. Unfortunately, after the manner of the times, no original label was attached to the specimen, but there is no reason why the habitat should be doubted.

Mr. E. W. Nelson observes :- " While on my way to and from the Aleutian Islands, a Petrel, conspicuous by its white collar and under-surface, was seen repeatedly, and, although none were secured, yet it was identified by its peculiar pattern of coloration. These birds were seen both in May and October, while crossing a part of the Pacific, some 500 miles broad, bordering the Aleutian chain" (Rep. Nat. Hist. Coll. Alasika, No. 3, p. 64,1887$)$.

Mr. Henshaw (l. s. c.) suggests that the Petrels observed by Mr. Nelson may have been Estrelata fisheri of Ridgway, which has also been procured in the North Pacific Ocean, near Alaska. 



\section{OCEANODROMA HORNBYI.}

Adult (type of species). Ashy-grey above, the upper tail-coverts white at the base and edged with white; lesser wing-coverts blackish, the rest pale ashy-brown; primary-coverts and quills black, the inner secondaries brown, externally ashy-grey; crown of head, with the feathers round the eye and ear-coverts, slaty-black; lores, sides of face and throat pure white, like the rest of the under-surface; across the fore-neck a broad band of slaty-grey; under tail-coverts white; under wing-coverts and axillaries ashy-brown, the latter broadly margined with white. Total length about 8.8 inches ; culmen, 0.65 ; wing, 6.0 ; tail, 3.9 ; tarsus, 1.0 ; middle toe and claw, 0.95 .

The above description and the figure in the Plate are taken from the typical specimen in the British Museum, which still remains unique in that institution. 


\title{
16. OCEANODROMA FURCATA (Gm.).
}

\author{
(GREY FORK-TAILED PETREL.)
}

(Plate 11.)

Fork-tailed Petrel, Penn., Arctic Zool., II., p. 255 (1785).

Procellaria furcata, Gm., Syst. Nat., I., p. 561 (1788).

Procellaria orientalis, Pall., Zoogr. Rosso-Asiat., II., p. 315 (1811).

Pachyptila furcata, Steph., in Shaw's Gen. Zool., XIII., p. 255 (1826).

Thalassidroma furcata, Gray, List Anseres, Brit. Mus., p. 161 (1844).

Oceanodroma furcata, Bp., Consp. Av., II., p. 194 (1856); Salvin, Cat. Birds Brit. Mus., XXV., p. 357 (1896).

Pulchre margaritaceo-cinereus, subtus vix pallidior.

THIS species is easily distinguished by its pearly-grey colour above and below.

The range of $O$. furcata is from the Aleutian Islands and Copper Island in Bering Sea, where it breeds, south to California. It also occurs at Plover Bay in North-Eastern Siberia, according to Mr. E. W. Nelson (Report Nat. Hist. Coll. Alaska, No. 3, p. 64, 1887).

Mr. Nelson (l. c.) writes:- "The Aleutian Islands form the main home of this elegant bird, which is seen in the North Pacific for one or two hundred miles south from the islands, but the passes and waters within a few miles of the outer shores afford them their most frequented haunts. In the middle of June, 1877, they were common off shore west of Nunivak Island, in Bering Sea, and they are frequent autumnal visitants to all parts of this sea. I obtained several specimens at St. Michael's, usually during October. The Eskimo find them even after the sea is covered with ice. At such times they are generally near an air-hole, and in several cases were captured alive, being too weak from starvation to escape. They are also sometimes found on the Lower Yukon, and, strangely enough, one was captured about 75 miles up the Janana River, where the bird was sitting on the ice near an air-hole in November. During the cruise of the 'Corwin,' in 1881, these Petrels were seen on several occasions in Bering Straits and about St. Lawrence Island, and in Plover Bay, Siberia. 


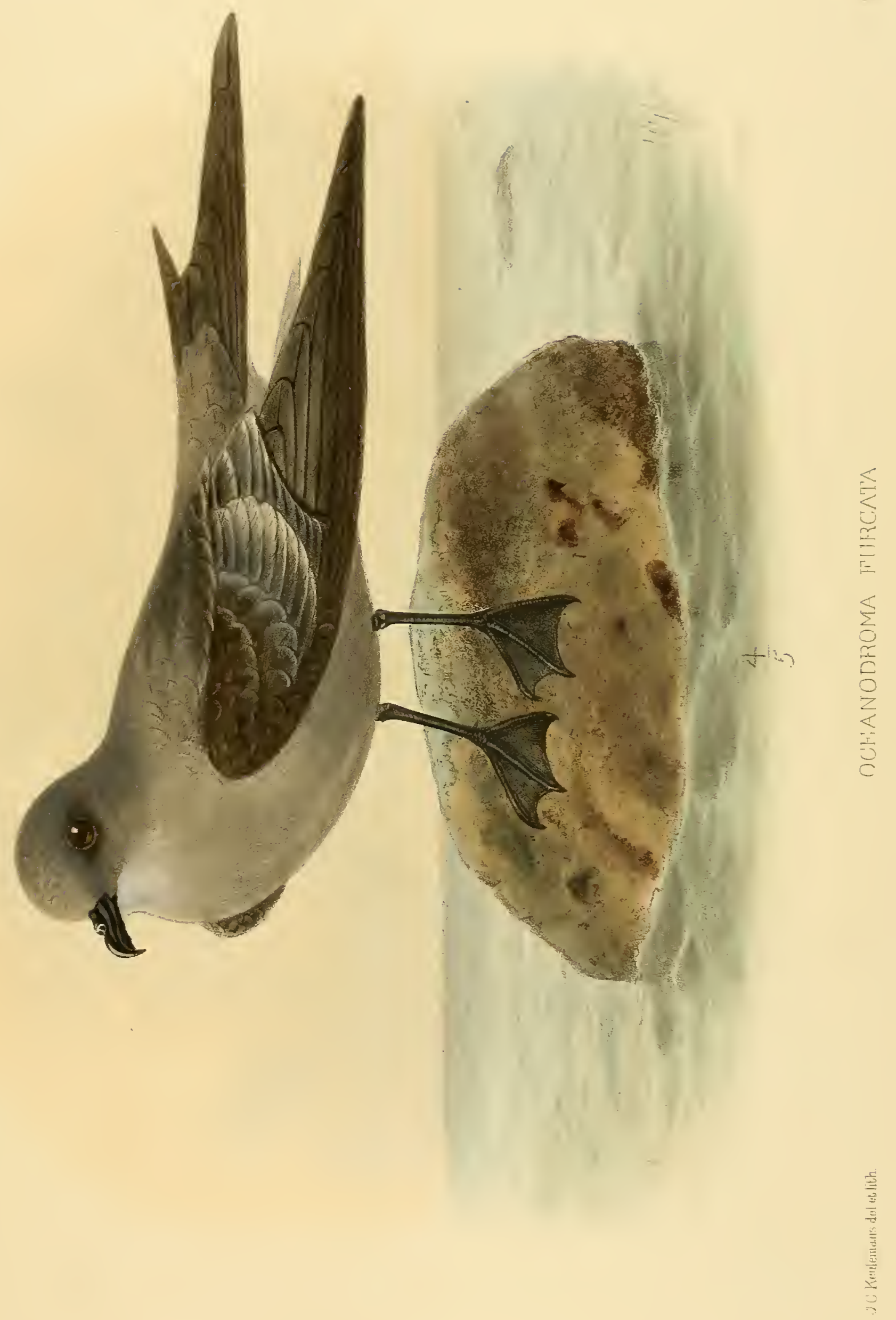




\section{OCEANODROMA FURCATA.}

"Two specimens were taken in Kotzebue Sound by the Eskimo during my residence at St. Michael's, so that its range reaches to the Arctic Circle. The species was found breeding on the Chica Rocks, in Akoutan Pass, near Unalaska, on June 2nd, by Mr. Dall. - . The same naturalist afterwards found the birds breeding from the pass named west to the end of the chain."

Dr. Stejneger has discovered the species nesting on Copper Island, one of the Commander group. He found a small colony breeding on the precipitous rocks of Tschornij Mys, between Karabelnij and Glinka, on the eastern side of Copper Island. The native name is "Sturmofka" (Orn. Expl. Kamtsch., p. 98). According to Taczanowski, a specimen was obtained by Dybowski on Bering Island (Tacz., Mem. Acad. Petersb., XXXIX., p. 1,068, 1891).

Mr. L. M. Turner, in his "Contributions to the Natural History of Alaska" (p. 129), states that he observed many of these Petrels when travelling among the Aleutian Islands; they were, however, rarely seen near land, but were abundant out at sea. The natives asserted that the species bred abundantly on the cliffs of Korovinsky Volcano, on the north-east shoulder of Atkha Island, and he saw the species as far west as Attu Island.

Specimens from Sitka, collected by Barclay and Bischoff, are in the British Museum, which also possesses a specimen procured by Dr. Lyall, near Vancouver Island. The range of the species on the Pacific coast of North America is stated in the second edition of the "A. O. U. Check-list" to extend to Humboldt Bay, California. From the Kuril Islands, the present species was recorded by Pallas (Zoogr. Rosso-Asiat., II., p. 315), who states that Mr. Merck, who accompanied Billings' expedition, brought back many specimens from the further Kuril Islands. Von Schrenk also records it from this group of islands (Reis. Amurl., I., p. 515). Dr. Stejneger gives the following note on the species :- "Snow found it breeding in various places. Seebohm specifies Rashau-Island, and gives as authority for the statement the names of Blakiston and Pryer, but I cannot find that they ever made it. His last reference (Ibis, 1884, p. 33) concerns Blakiston's specimen (No. 1819), which, according to Blakiston's 'Catalogue,' was not from the Kurils at all, but from Kamtschatka."

Every observer testifies to the singular beauty of this little Petrel in life. Mr. Nelson says that its soft delicate plumage renders it one of the most elegant of the northern water-fowl, and especially marked among the other Petrels. In its habits it resembles Leach's Petrel.

Eggs taken by Dr. Stejneger on Copper Island measured :--axis, 1.3-1.4 inch ; diam. 1.0-1.1. They were white, without any gloss, one having abundance of the minutest dark spots evenly dusted over the blunt end; in another these specks were a little larger, purplish-black, and forming a circlet round the blunt end, while a few lilac spots shone through from the deeper layers (Orn. Expl. Kamtsch., p. 98). Mr. Dall found the nests, consisting of a little dry grass and fine roots, placed at the bottom of holes in 


\section{MONOGRAPH OF THE PETRELS.}

the cliffs, extending obliquely downwards. Both sexes, according to Dr. Stejneger, take part in the incubation.

Adult male. General colour delicate pearly-grey, the under-surface somewhat lighter than the back; least wing-coverts, as well as those round the carpal bend of the wing, and the upper scapulars, blackish ; median and greater wing-coverts ashygrey, with narrow white external edges; primary-coverts and primaries blackish, the latter narrowly fringed with white near the ends; secondaries broadly edged with white, the innermost dusky like the scapulars; tail-feathers ashy-grey, dusky towards their tips, the outermost feather externally white; head light pearly-grey like the back ; base of forehead and lores hoary-grey; feathers before and behind the eye black; cheeks and throat greyish white; remainder of under-surface pure light grey, the lower abdomen and under tail-coverts white, tinged with grey; under wing-coverts smoky brown, margined with white, the greater series more ashy, hoary-white at their ends; axillaries also smoky-brown with white ends; quills ashy below, white towards the base of the inner web; bill and feet black; iris dark brown.

Total length, about 7.5 inches; culmen, 0.6 ; wing, 6.2 ; tail, 3.3 ; tarsus, 0.9 ; middle toe and claw, 1.1.

Adult female. Similar to the male. Total length about 8 inches; wing, 6.2.

The descriptions are taken from a pair of birds in our collection, procured by Mr. E. W. Nelson at St. Michael's, Alaska. The Plate represents a female bird from Sitka, also in our collection. 


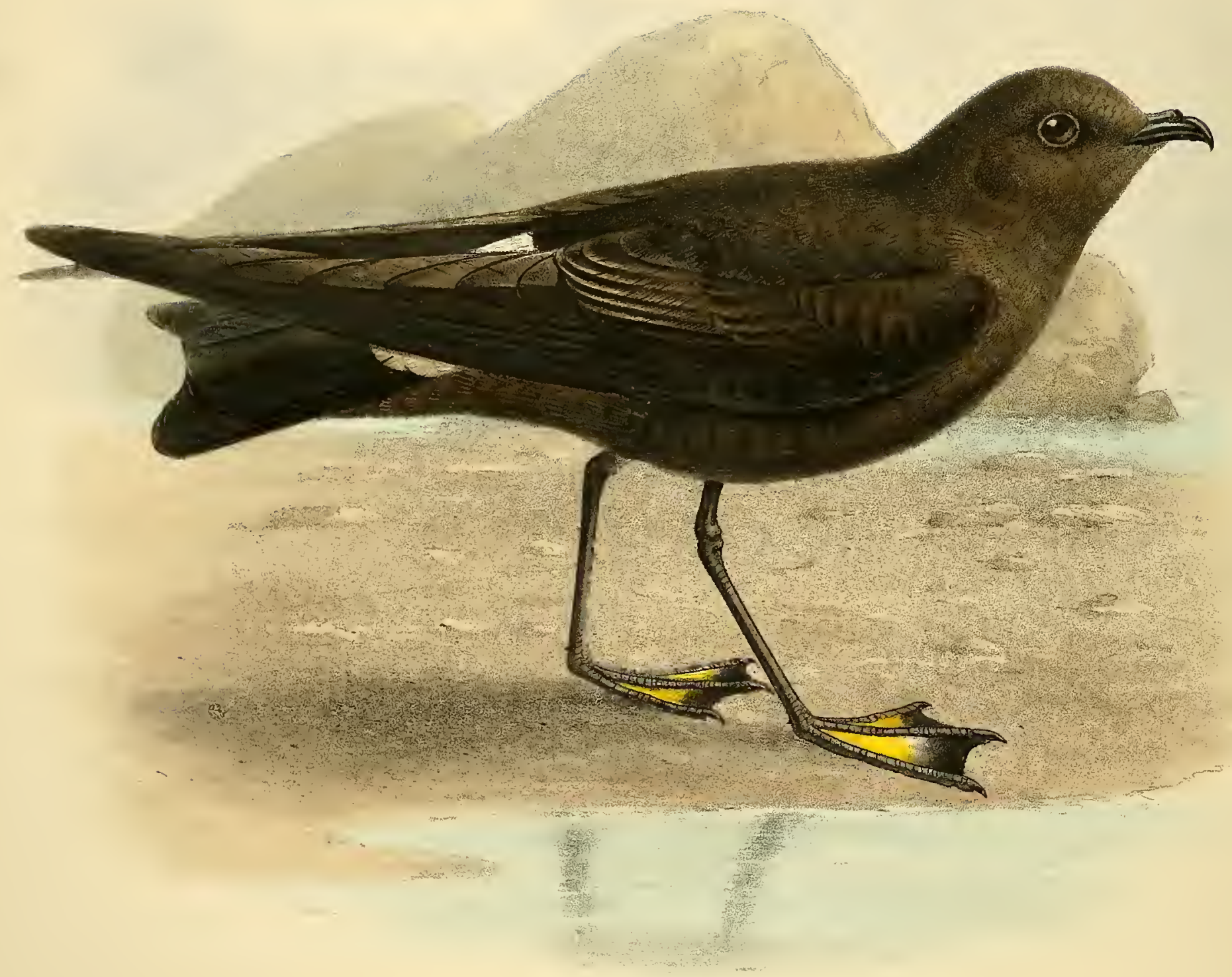




\section{OCEANITES OCEANICUS (Kuhl).}

\section{(WILSON'S STORM-PETREL.)}

(Plate 12.)

Procellaria pelagica (nec Linn.), Wilson, Amer. Orn., VII., p. 90, Pl. 60, Fig. 6 (1813).

Procellaria oceanica, Kuhl, Beitr., p. 136 (1820, ex Banks Icon. Ined., No. 12).

Procellaria wilsoni, Bp., Pr. Acad. Philad., III., p. 231, Pl. 9 (1823).

Wilson's Stormy Petrel, Nutt., Man. Water Birds, p. 322 (1834).

Oceanites wilsoni, Keys, u. Blas. Wirb. Eur., pp. XCIII., 238 (1840); Giglioli, Faun.

Vertebr. Oceano, p. 38 (1870); Seebohm, Hist. Brit. Birds, III., p. 449 (1885).

Thalassidroma oceanica, Schinz, Eur. Fauna, I., p. 397 (1840).

Wilson's Petrel, Yarrell, Brit. Birds, III., p. 516 (1843).

Thalassidroma wilsoni, Audub., Birds Amer., 8vo ed., VII., p. 223, pl. 460 (1844).

Oceanites oceanicus, Bp., Consp. Av., II., p. 199 (1856); Sharpe, Phil. Trans., Vol.

CLXVIII., p. 132 (1879) ; Salvin, Voy. "Challenger," Zool., II., pt. 8, p. 141

(1881) ; id., Cat. Birds Brit. Mus., XXV., p. 358 (1896); Sharpe, Rep. Coll.

"Southern Cross," p. 139 (1902) ; Wilson, Rep. Nat. Antarctic Exped., Aves, p. 76 (1907).

Fulginoso-brunneus, tectricibus supracaudalibus albis; palmis interdigitalibus aurantiaco-flavis.

Wrison's Storm-Petrel is one of the most widely distributed of the whole Order Tubinares, having been found everywhere except in the North Pacific Ocean. It has been suggested that two forms of the species exist, viz., a northern and a southern one, the former having been separated by Bonaparte as larger, and having a more slender bill and longer tarsi, while, at the same time, there was less white on the wing, and the tail was emarginate.

Professor Giglioli was inclined at one time to agree with Bonaparte, and believed that the larger form, $O$. oceanicus, was confined to the South Atlantic Ocean, the Indian Ocean, and the Australian seas. O. wilsoni, on the other hand, was considered to inhabit the North Atlantic islands, the coasts of the United States, and the Pacific 


\section{MONOGRAPH OF THE PETRELS.}

Ocean, along the coast of America to Chile and Peru. On comparing a series of specimens from northern and southern latitudes, I cannot find any difference in colour or markings ; in both there are occasional examples with whitish edgings to the wingcoverts, but these are apparently a sign of immaturity, as with other Storm-Petrels.

As regards any difference in size between northern and southern individuals, it may be mentioned that eleven specimens from the coast of Massachusetts measure as follows :-

б Wing, 5.5-6.0 inches ; tarsus, 1.3-1.4 inch.

\& Wing, 5.2-6.2 inches ; tarsus, 1.3-1.4 inch.

Twelve specimens from the Antarctic Pack Ice and South Victoria Land give the following measurements :-

ชิ Wing, 5.8-6.2 inches; tarsus, 1.25-1.35 inch.

o Wing, 6.0-6.35 inches; tarsus, 1.3-1.35 inch.

It is evident, therefore, that there is no distinction in size between specimens from northern and southern latitudes.

Since Professor Giglioli wrote, our knowledge of the distribution of Wilson's Petrel has been greatly increased by the observations of the naturalists attached to the exploring ships which have visited the Antarctic continent, and the species has been found nesting there as well as on Kerguelen Island, the South Shetlands, and South Orkney Isles. Mr. Howard Saunders has given the following excellent summary of the southern range of $O$. oceanicus in the "Antarctic Manual" (p. 235):- "It was observed by Dr. McCormick hovering, like a Swallow or Martin, over the mast-head of the 'Erebus,' when in the pack; and, on the third attempt to go southwards, examples (now in the British Museum) were obtained off Louis Philippe Land, in January, 1843. These birds were evidently incubating at no great distance, as their breasts were bare of feathers. Surgeon Webster, of H.M.S. 'Chanticleer,' refers to the abundance of this species at Deception Island, one of the South Shetlands. The 'Belgica' obtained specimens in Gerlache Strait in January, 1898, as well as in the Pack at about $70^{\circ} \mathrm{S}$. Lat. and $87^{\circ} \mathrm{W}$. Long., in January, 1899. The 'Challenger' expedition secured several off the Ice Barrier in February, 1874, and examples were obtained during the voyage of the 'Southern Cross' between $63^{\circ}$ and $66^{\circ} \mathrm{S}$. Lat., and $161^{\circ}$ and $166^{\circ} \mathrm{E}$. Long."

The species was discovered by the naturalists of the latter expedition breeding on Cape Adare. Mr. L. Bernacchi observed it every day during the passage of the "Southern Cross" through the Pack Ice, and as far south as the Great Ice Barrier. He records it as nesting high up on the mountain sides of South Victoria Land. Mr. Nikolai Hanson, the zoologist on the "Southern Cross," remarked that it disappeared from there early in March.

Several specimens were obtained during the voyage of the "Discovery," and Dr. E. A. Wilson says that the bird is evidently a migrant to the Antarctic Ocean, 


\section{OCEANITES OCEANICUS.}

disappearing at the approach of the southern winter. It was not seen in McMurdo Sound from the end of February to the middle of December. In the latter month and in January, 1904, when camped on the sea-ice under Dellbridge Islands, numbers of these Storm-Petrels were observed, but no eggs were discovered; nor was the species found nesting at Cape Royds, which seemed a more suitable place, being some miles nearer to the open water and consequently to its food supply (Wilson, Rep. Nat. Antarctic Exped., II., p. 76).

On the voyage out to New Zealand, the "Discovery" made a détour into the Pack Ice, and Dr. Wilson informs us that $O$. oceanicus was first met with on November 7 th and 8th, when several were noticed following the vessel in and out of the ice, and northwards till Macquarie Island was reached. Between this island and New Zealand none were seen, nor was the bird again observed until the southern voyage, when the "Discovery" once more approached the Pack Ice, and it was afterwards found breeding at Cape Adare. Dr. Wilson further states that not a day passed in the summer cruising of the "Discovery," that he did not see a few of these Storm-Petrels. Although not in large numbers they were, nevertheless, always present till February 7 th in 1902, when he saw the last. As the "Discovery" left the southernmost area, the species was noticed each day from February 19th to March 3rd, but on that day, when among the Balleny Islands, the last of the icebergs was met with, and with them Oceanites disappeared. Two days later, when in S. Lat. $6^{\circ}$, Cymodroma grallaria occurred, and from that time became more and more abundant, apparently taking the place of Wilson's Petrel (Wilson, $l$. c.).

Dr. Wilson further records that this species was seen by sledging parties on more than one occasion, on the ice plain of the Great Barrier, some sixty miles from open water ( $78^{\circ} 30^{\prime} \mathrm{S}$. Lat.), but always on the wing, and apparently untiring.

Professor Einar Lönnberg states that a flock of Storm-Petrels was observed by the Swedish South-Polar Expedition in "Erebus and Terror" Gulf, in Louis Philippe Land; but whether the birds were all Oceanites oceanicus, or whether some of them were Cymodroma melanogaster could not be determined, as all the specimens obtained were lost (Wiss. Ergebn. Schwed. Sïd-Polar Exped., V., Pl. 5, p. 3, 1895).

The species nests on Kerguelen Island, eggs having been discovered by the Rev. A. E. Eaton during the "Transit of Venus" Expedition (cf. Sharpe, Phil. Trans., Vol. CXLVIII., p. 133). Dr. Kidder also met with it, but did not succeed in finding the eggs (Bull. U. S. Nat. Mus., II., p. 30, 1875). Mr. Robert Hall also found many nests on Kerguelen Island during his visit from December, 1897, to February, 1898 (Ibis, 1900, p. 22).

Wilson's Storm-Petrel was met with by the Scottish Antarctic Expedition under the leadership of Dr. W. G. Bruce, when it was found breeding on the South Orkney Islands (Eagle Clarke, Ibis, 1906, p. 168, Pl. X., Fig. 1).

0 . oceanicus is distributed over the southern oceans, occurring in the Australian 


\section{MONOGRAPH OF THE PETRELS.}

seas and off New Caledonia, but it is not yet recorded from the Pacific islands or the waters of the Northern Pacific Ocean. In the Indian Ocean, Professor Giglioli observed it always in company with Cymodroma melanogaster (Faun. Vertebr. Oceano, p. 37), and a specimen, procured by Colonel E. A. Butler off the Mekran coast on the 28th May, 1877, is now in the Hume Collection in the British Museum (Hume, Stray F., V., p. 291). Wilson's Storm-Petrel has also been recorded from the Cape of Good Hope by Sir Andrew Smith, and by the late C. J. Andersson from the coast of Damara Land. A specimen was also obtained by the late Governor Ussher, on the Gold Coast (Sharpe, Ibis, 1872, p. 74). I myself met with the bird near the Azores in 1860, thirty miles to the west of Fayal (Ibis, 1866, p. 104).

It extends its northward range to the Bay of Biscay, and is sometimes not uncommon in our British seas. Mr. Howard Saunders, in his "Manual of British Birds," summarises the occurrences of Wilson's Petrel in Western Europe as follows:- "In France three examples have been taken in the Gulf of Gascony, all of them in December, while stragglers have occurred on the coast of Provence. I have a bird, in moult, captured off Malaga on 7th August, 1873 ; and Count Salvadori has identified a specimen in the University Museum of Cagliari, said to have been obtained off Sardinia. As regards the British Islands, Gould observed this species in abundance off Land's End in May, 1838, and in November of the same year a specimen was found dead near Polperro, in Cornwall ; an example has been picked up near Chippenham, in Wiltshire ; two have been obtained near Freshwater, in the Isle of Wight (the last in the autumn of 1888); the late Mr. F. Bond recorded one from Sussex; one was shot near Halifax, in Yorkshire, in November, 1874 ; and three have occurred in Cumberland, the latest of them in November, 1890. Mr. Henry Evans secured an example on Jura early in October, 1891, the first for Scotland. As regards Ireland, a specimen which was supposed to have been obtained in co. Dublin was presented to Thompson in August, 1840, by Glennon; while on the 1st and 2nd October, 1891, examples were secured in co. Down and co. Antrim respectively."

O. oceanicus has been observed in large flocks in mid-Atlantic, and off the coast of North America. In our northern spring Mr. L. M. Turner found it abundant off Labrador (Pr. U. S. Nat. Mus., VIII., p. 253, 1885).

To the southward this Petrel has been observed in many parts of the South Atlantic Ocean, and doubtless occurs at certain seasons off the West Indian Islands, but at present the only certain record is that of Dr. Wells, who states that it is seen off Carriacou Island in stormy weather $(A u k, 1902$, p. 241). Mr. A. H. Clark also noticed it in the vicinity of Margarita Island, off Venezuela ( $A u k, 1902$, p. 260).

A specimen from the neighbourhood of Bahia was in Dr. Wucherer's collection, and Professor Giglioli recorded the species from the vicinity of the Falkland Islands (Faun. Vertebr. Oceano, p. 37) and as far north as Callao on the Pacific coast of South America. 


\section{OCEANITES OCEANICUS.}

The habits have been well described by Dr. Wilson, who states that the flight is peculiarly attractive in the barren wastes of snow and rock, chiefly, perhaps, from its resemblance to that of the familiar Martin, for it flits here and there, exactly as though in search of insects on the wing. Occasionally it sails on outstretched wings. The power of flight, he says, must be very remarkable, for it seems to spend its life on the wing.

The practice of hovering, in which this Petrel sometimes indulges, was first noticed by Dr. McCormick, who saw it sailing above the mast-head of the "Erebus" when in the Pack Ice, during the first Antarctic Expedition. The late Nikolai Hanson, the zoologist to the "Southern Cross," also says that on the 8th March he saw a bird performing evolutions in the air, at a height of about 200-300 metres, like a Swift. He often observed these birds, both when on board the "Southern Cross" and after the landing at Cape Adare, flying round the ship and the house, in the evenings after dark, like Bats, which they very much resembled in their flight (Rep. Voy. "Southern Cross," p. 94).

The food, according to Dr. Wilson, consists of minute crustaceans, picked up from the surface of the water while on the wing. Flitting about from wave to wave, the little Petrel delicately treads the water, to steady itself a moment, while it picks up a tiny morsel (Wilson, $l$. c.).

There seems to be considerable variation in the mode of nesting. The Rev. A. E. Eaton, who was the first to discover authentic eggs, found the bird on Kerguelen Island inhabiting the slopes of shattered rocks with suitable chinks and crevices, or dry spaces under stones or large boulders, sheltered from draughts, whether they were near the Sound, or on the sides and summits of high hills. The egg was laid upon the bare ground within the recess selected, either in a chance depression formed by the contiguous stones, or in a shallow circular hollow excavated in the earth by the parent (Phil. Trans., Vol. CLXVIII., p. 133).

The naturalists of the "Scotia," who procured eggs on the South Orkney Islands during the Scottish Antarctic Expedition, foumd that there was no attempt at nestmaking, and the egg was very difficult to obtain, being laid in a hollow in the earth in narrow clefts and fissures in the face of the cliffs or under boulders, and sometimes stones on the screes sloping from the foot of the precipice, at heights varying from 20 to $300 \mathrm{ft}$. above sea level.

At Cape Adarc, in South Victoria Land, Dr. Wilson perceived some of these StormPetrels hovering round the mouth of crevices in the rocky side of the cliff, often settling close by for a few seconds and then sailing in short circles round it, reminding him strongly of the movements of a House-Martin at its nest under the eaves of a country barn. He adds the following interesting note :- "Two of these crevices could not be reached, but soon we saw a bird hover round and settle upon a large boulder. Hunting about for a burrow underneath, we caught the sound of twittering, and traced it to a 


\section{MONOGRAPH OF THE PETRELS.}

kind of mouse-hole. This, by dint of long and tedious picking with a sheath-knife, we enlarged till it admitted an arm up to the shoulder. The work was laborious, as the floor of the burrow was hard black ice and grit, but eventually we reached the nest. At the end of the little tunnel was a chamber containing a very comfortable nest thickly lined with Adélie Penguin's feathers, and in it a somewhat remarkable collection. First we brought out an adult male alive, then an adult female ; then two eggs, one clean and newly-laid, the other old and rotten, and under all another dead and flattened adult Oceanites. Outside, as we worked, a fourth bird was hovering, which, when shot, proved to be an adult male. It has been long known that with this species the nesting burrow has been often used by more than a single pair."

It will be noticed that Dr. Wilson mentions a decayed body of one of these birds being found in the nest, as well as an addled egg. It seems probable that more than one pair inhabit the same breeding site, as Mr. Bernacchi speaks of finding five eggs in one nest, but not all of them fresh. In the South Orkneys, writes Mr. Eagle Clarke (l. c.), " they appear to return year after year to the same nesting places, for both eggs and dead young birds of previous seasons were numerous in the tenanted holes containing the fresh eggs. This fact indicates that a very serious waste of life takes place in some seasons, if not annually. It may be accounted for by the late arrival of the bird at its breeding station, which, coupled with the lengthened period of incubation characteristic of all Petrels, results in winter setting in ere the eggs are hatched, or the young, which develop slowly, are old enough to leave the nesting-holes. Another, and perhaps more probable, explanation is that the disasters noticed were due to a succession of cold summers, which are actually known to have occurred. None of the eggs in the summer of 1903-1904 had been hatched when the expedition left the islands on 21st February. We may therefore infer that the South Orkneys lie at the extreme limits of breeding for Wilson's Petrel; indeed, for many individuals of this species -perhaps all-during some seasons the climatic conditions place the islands distinctly beyond that range, though it breeds further south, with similarly disastrous results."

Eggs of Wilson's Storm-Petrel in the British Museum are of an elongated oval form. They are dull white, peppered with tiny dots of reddish brown and underlying lilac, mostly accumulated round one end of the egg, but occasionally sprinkled all over the surface. Axis, 1.3 inch ; diam., 0.9.

Adult male. General colour sooty-brown, with a tinge of leaden-grey; the scapulars and lesser wing-coverts like the back, the median and greater coverts rather lighter and of an ashy-brown, forming a slightly pronounced wing-patch; primarycoverts and quills black, the innermost secondaries brown like the wing-coverts; upper tail-coverts white ; tail-feathers black; head and neck, as well as the throat, sooty-brown, with a distinct shade of leaden-grey; remainder of under-surface sooty-brown, a little lighter than the back; on each side of the vent a patch of white feathers on the lower 


\section{OCEANITES OCEANICUS.}

flanks, adjoining the white upper tail-coverts; under tail-coverts sooty-brown, the lateral ones white, some of them brown internally; under wing-coverts and axillaries like the breast, the greater series and the quill-lining a little greyer ; "bill entirely black; feet and toes black, the webs black at the outer border, and black also along the sides of the outer digits, but otherwise bright orange from the base of the first phalange to a point level with the second phalange ; claws black ; iris dark brown " (E. A. Wilson). Total length, about 7.5 inches ; culmen, 0.6 ; wing, 6.0 ; tail, 2.6 ; tarsus, 1.4 ; middle toe and claw, 1.2.

Adult female. Similar to the male. Total length, 7.5 inches; wing, 6.2 ; tarsus, 1.35 .

Nestlings. "Covered with a uniform greyish-black down; bill black; legs bluish, tinged with faint yellow, webs of toes bright yellow; toes faint black; nails black" (Robert Hall).

The descriptions are taken from a pair of birds in the Gerrit Miller Collection in the British Museum, procured at Provincetown, Mass., on 17th August, 1891. The bird figured in the Plate is a male procured by myself at sea, about thirty miles west of Fayal. 


\section{OCEANITES GRACILIS (Elliot).}

(ELLIOT'S STORM-PETREL.)

(Plate 13.)

Thalassidroma gracilis, Elliot, Ibis, 1859, p. 391.

Oceanites gracilis, Coues, Pr. Philad. Acad., 1864, p. 85 ; Salvin, Cat. Birds Brit. Mus., XXV., p. 361, (1896); Rothsch. and Hartert, Nov. Zool., VI., p. 198 (1899), IX., pp. 416, 418 (1902).

Procellaria oceanica (nec Kuhl), Schlegel, Mus. P.-B. Procell., p. 6 (1863) ; Scl., P. Z. S. 1867, p. 336.

Oceanites wilsoni, Giglioli, Faun. Vertebr. Oceano, p. 38 (1870); id., Viagg. "Magenta," pp. 844, 888 (1875).

Procellaria gracilis, Scl. and Salv., Nomencl. Av., p. 148 (1873).

Thalassidroma wilsoni (nec Bp.), Coppinger, Cruise "Alert," p. 87 (1883).

O. oceanicce similis, sed minor et abdomine albo distinguenda.

This Storm-Petrel is distinguished from $O$. oceanicus by its smaller size and bill ; the white rump-band is much narrower, and the middle of the lower breast and abdomen is white.

The species was first described by Dr. D. G. Elliot from a male specimen, obtained off the coast of Chile in May. He does not give the name of the collector, nor does he state where the type-specimen was deposited, but it is evident from the notes which he appends to his account, that the original specimen must have been accompanied by some details of its capture. It was said to be very abundant on the coast of Chile, visiting the mainland only in the breeding season. During that period, for a great part of the day and night, the birds retired to the clefts of the rocks, taking flight only in the early morning. Both sexes were said to incubate, the eggs being white and two in number. The birds were frequently met with in flocks of ten to fifteen individuals, scattered over a small space at a distance of from thirty to forty miles from the shore. Dr. Elliot tells me that, at this lapse of time, he does not remember the exact circumstances under which he described the type-specimen, but, to the best of his 


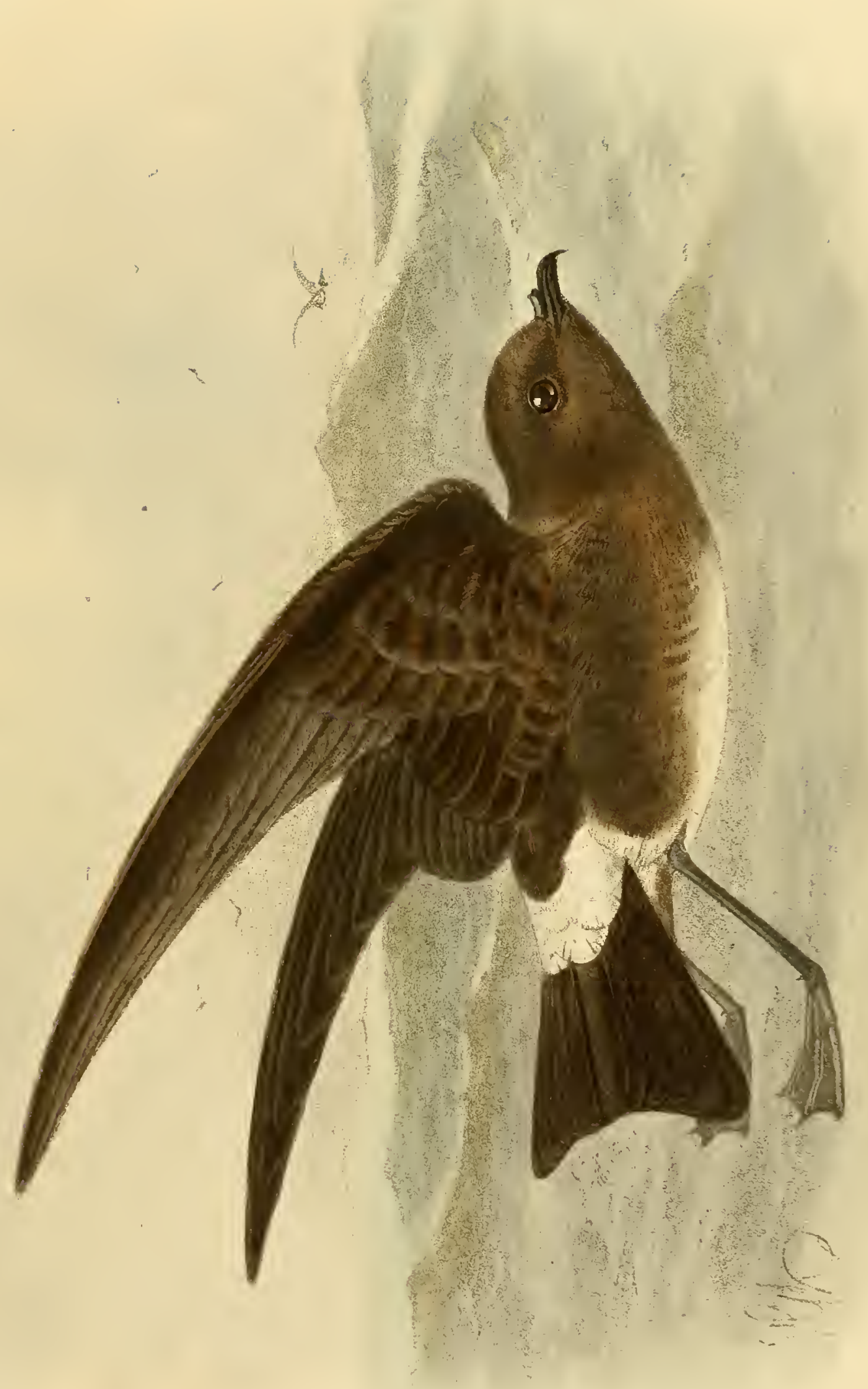

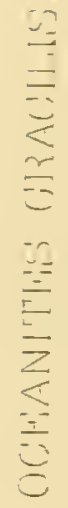

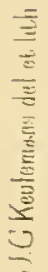





\section{OCEANITES GRACILIS.}

recollection, it was in the "Maison Verreaux," and he understood that it was to be offered to the British Museum. The specimen, however, never came to this institution.

An example procured by Mr. A. A. Lane at Iquique, in Northern Chile, was presented to the British Museum by the late Mr. Berkeley James.

$O$. gracilis is plentiful in the Galapagos Archipelago, and is recorded by the Hon. Walter Rothschild and Dr. Hartert from the following islands, viz. : Albemarle, Narborough, Chatham, James, Charles, Abingdon, and Bindloe (Nov. Zool., VI., pp. 198, 205; IX., pp. 416, 418).

Adult male. General colour above sooty-brown, blacker on the lower part of the back, with a white band formed by the upper tail-coverts ; scapulars and wingcoverts sooty-brown like the back, the greater series rather lighter brown and inclining to whity-brown on their margins, but not showing a conspicuous wing-patch ; primarycoverts and quills, black ; tail black, with white bases to the outer feathers; crown and sides of head a little darker than the back, the forehead slightly browner; throat, chest, and sides of body sooty-brown, lighter than the back ; centre of lower breast and abdomen, as well as the vent, white, some of the feathers more or less smudged with sooty-brown; on the side of the vent, adjoining the white band across the upper tailcoverts, a tuft of white feathers, more or less marked with brown near the ends; under tail-coverts sooty-brown, the lateral ones white, or white with brown ends; bill and feet black; iris brownish. Total length, 5.3 inches; culmen, 0.45 ; wing, 5.5 ; tail, 2.3 ; tarsus, 1.25 ; middle toe and claw, 0.95 .

Adult female. Similar to the male. Total length, 5.3 inches; wing, 5.5.

The birds described are a pair from Abingdon Islands, Galapagos, obtained by the Webster-Harris Expedition, and now in the British Museum. The specimen figured, I believe to have been the one obtained at Iquique by Mr. A. A. Lane, which was the only example available when the Plate was drawn. Salvin, however, has not left any note on the subject. 


\section{GARRODIA NEREIS (Gould). (GREY-BACKED STORM-PETREL.)}

(Plate 14.)

Thalassidroma nereis, Gould, P. Z. S., 1840, p. 178.

Procellaria nereis, Bp., Consp. Av., II., p. 196 (1856).

Oceanites nereis, Cab., J. f. O., 1875, p. 449.

Garrodia nereis, W. A. Forbes, P. Z. S., 1881, p. 735 ; Salvin, Cat. Birds Brit. Mus., XXV., p. 361 (1896).

Nigricans, uropygio et supracaudalibus clare cinereis: scapularibus et tectricibus alarum albo marginatis : gutture et præpectore nigricantibus : corpore reliquo subtus albo.

G. nereis was discovered by Gould on his expedition to Australia in 1839, between Hobart Town and Sydney, when he procured four examples, and he subsequently observed it in considerable numbers near the entrance to Bass's Straits, and later, on his homeward voyage between New South Wales and the northernmost part of New Zealand. It is known to breed there, as it has been found by Mr. Reischek on the Guano Island in the beginning of November, and by Mr. Percy Seymour on Tomahawk Island, Otago, on the 18th January (Buller, Birds New Zealand, 2nd ed., p. 247). The Earl of Ranfurly found the species on the Auckland Islands, where Captain Hutton asserts that it breeds (Buller, Birds New Zealand, Suppl., I., p. 98). It certainly does so on the Chatham Islands, as Mr. Travers obtained young birds there (Buller, $l$. $c$.), and Dr. H. O. Forbes procured the egg (Ibis, 1893, p. 542).

This Petrel was found by both the British and American naturalists who accompanied the "Transit of Venus" expeditions to Kerguelen Island. A female was captured by the Rev. A. E. Eaton in Royal Sound on the 6th November, but this was the only one observed, and he did not find any nest (Sharpe, Phil. Trans., Vol. CLXVIII., p. 129). Dr. Kidder, however, was more fortunate as he found the birds common at the American station at Molloy Point, and discovered the first eggs on the 12th December (Bull. U. S. Nat. Mus., II., p. 31, 1875). The nests were placed 

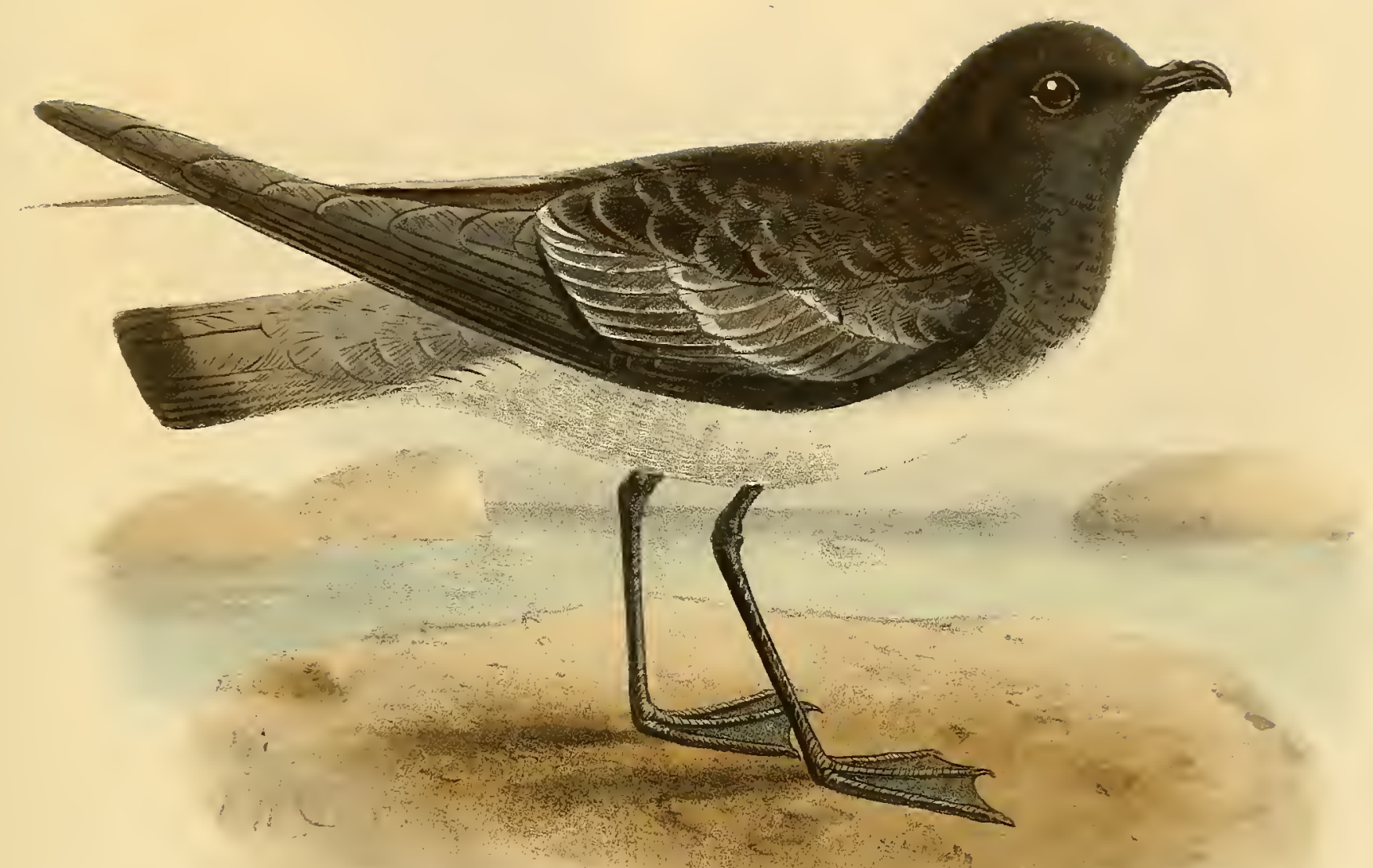


\section{GARRODIA NEREIS.}

under overhanging clumps of grass and "Kerguelen tea" (Accena ascendens) in low swampy ground near the sea.

The present species ranges to the Falkland Islands, but has not yet been found breeding there. Captain Abbott states that one of these Storm-Petrels was picked up dead in March, 1858 (Ibis, 1861, p. 164), and Salvin also received a specimen from the Falkland Islands Company, which is now in the British Museum (cf. Salvin, Cat. Birds Brit. Mus., XXV., p. 362).

During the breeding season the birds become very fat, according to Dr. Kidder (l. c.), who says that they are strictly crepuscular in their habits, and therefore none were seen flying by daylight. Mr. Eaton says that the single specimen he captured had the Crake-like call of $O$. oceanicus.

In New Zealand, Sir Walter Buller relates that he was informed by Mr. Percy Seymour that the nests were placed in burrows resembling rat-holes about 15 in. deep. All the sitting birds he found were females, whereas all those captured by Dr. Kidder were males.

Like other species of Petrels, G. nereis is sometimes blown inland by stress of weather, and Sir Walter Buller mentions an instance of a foot-passenger on the Wanganui Bridge in New Zealand, catching a specimen with his hands as it flew past, and on another occasion a bird was captured some miles inland while flitting round the wood fire of a bushman's camp.

Five eggs of $G$. nereis are in the British Museum. One collected by Dr. H. O. Forbes in the Chatham Islands is white, dusted with reddish dots and underlying dots of lilac; axis, 1.35 inch; diam. 0.95. Four more specimens have been presented by Mr. Philip Crowley. The locality was said to have been the Southern Ocean, but no further information is forthcoming. They are larger than the Chatham Island specimen, and one is much rounder in shape. These four specimens are pure white, but with scarcely any spots or markings whatever.

Adult female. General colour above dark ashy-grey, rather lighter towards the rump and upper tail-coverts, the latter with blackish shafts and a slight indication of dusky tips, the outer coverts somewhat whitish near the base; tail-feathers also ashygrey, with black shafts and a distinct black bar at the ends; scapulars grey like the back. the bases pale grey, and the longer feathers darker and more blackish grey; wingcoverts for the most part black, the greater series ashy, with white fringes at the ends; bastard-wing, primary-coverts and quills, blackish, shaded with ashy-grey, and with black shafts, the inner webs of the quills hoary-white towards the base; head and neck blackish, extending over the mantle, the forehead slightly browner ; sides of face like the crown; throat and chest slightly more dusky brown, this extending to the sides of the upper breast; rest of under-surface of body pure white, including the under tail-coverts, the lateral coverts being freckled or barred with dusky; under wingcoverts for the most part white, with a broad black band round the entire margin of 


\section{MONOGRAPH OF THE PETRELS.}

the wing; quills dusky, the inner webs whitish towards the base; "bill, feet, and iris black" (Gould).

Total length, about 7 inches; culmen, 0.5 ; wing, 5.05 ; tail, 2.65 ; tarsus, 1.15 ; middle toe and claw, 1.05 .

Young. Differs from the adult in having hoary-white margins to the feathers of the back and scapulars, as well as the upper wing-coverts and tail-coverts, the latter thus showing a dusky black sub-terminal bar.

The bird described is a female specimen from Royal Sound, Kerguelen Island, in the British Museum; and the specimen figured is one from the Falkland Islands in our collection. 



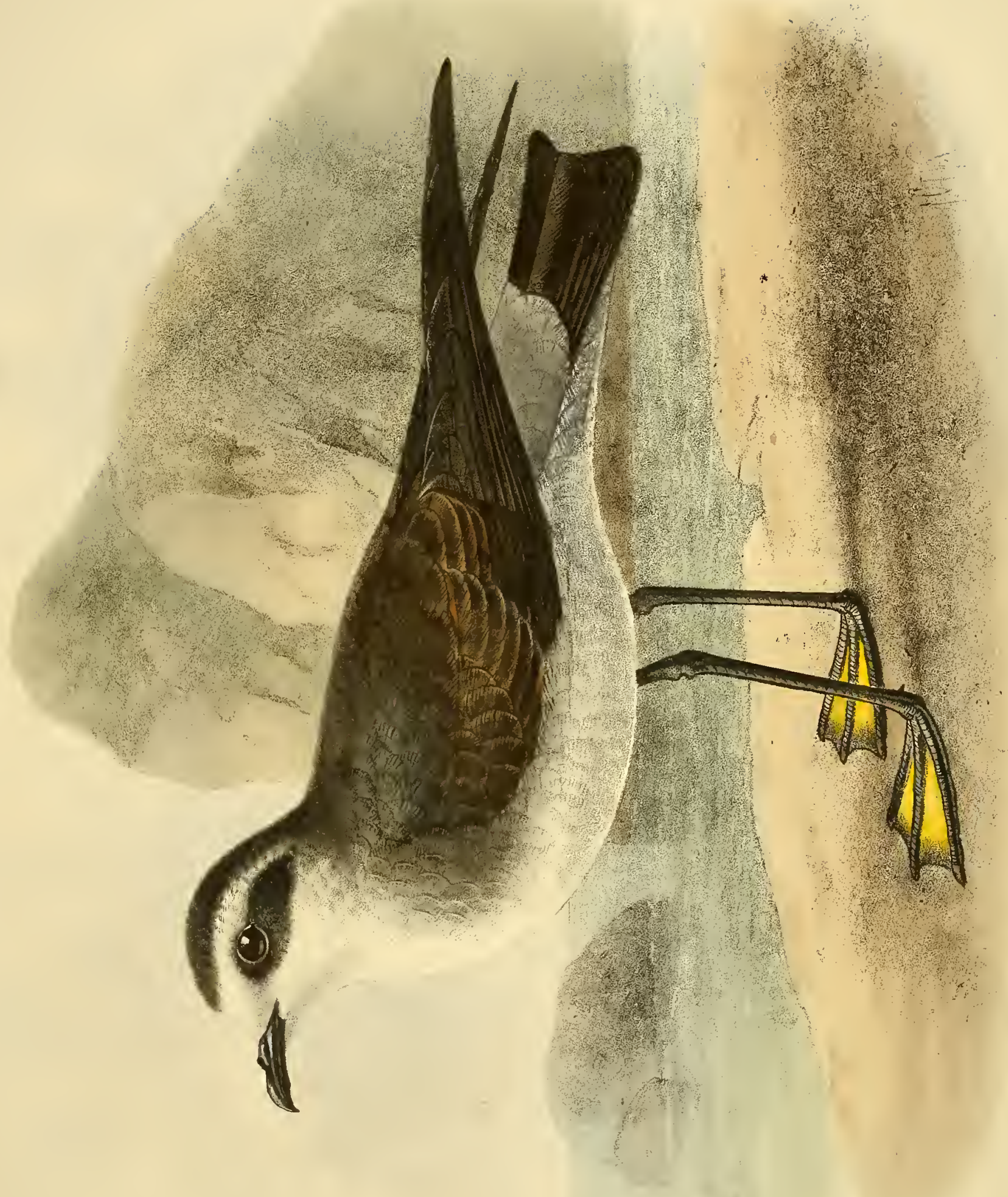

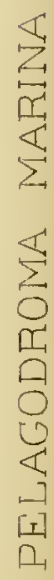




\section{PELAGODROMA MARINA (Lath.).}

(WHITE-FACED STORM-PETREL.)

(Plate 15.)

Procellaria cequorea, Solander MSS.; cf. Salvin, in Rowley's Orn. Misc., I., p. 238 (1876).

Frigate Petrel, Lath., Gen. Syn., III., p. 410 (1785).

Procellaria marina, Lath., Ind. Orn., II., p. 826 (1790).

Pachyptila marina, Steph., in Shaw's Gen. Zool., XIII., p. 253 (1826).

Oceanites marinus, Keys and Blas., Wirb. Eur., p. 93 (1840).

Thalassidroma marina, Gray, List Anseres, Brit. Mus., p. 161 (1844).

Thalassidroma hypoleuca, Moquin-Tandon, in Webb. and Berth. Orn. Canar., p. 45 (c. 1841).

Pelagodroma marina, Reichenb., Av. Syst. Nat., p. 4 (1852); Salvin, Cat. Birds Brit. Mus., XXV., p. 362 (1896).

Pelagodroma fregata, Bp., Consp. Av., II., p. 198 (1856).

Procellaria fregata (nec Linn.), Schl., Mus. Pays Bas, VI., Procell., p. 5 (1863).

Thalassidroma fregata (nec Linn.), Buller, Birds N. Zeal., p. 321 (1873).

Cineracea: pileo nigricante; uropygio imo et supracaudalibus clarius cinereis; alis caudaque nigris; fronte et superciliis, genis et corpore subtus toto pure albis; regione parotica et plumis subocularibus nigris.

THIS pretty little Storm-Petrel has a very wide range, as it has been found breeding on the islands off the coasts of Southern and Western Australia, and again on the Cape Verde and Salvage Islands in the Atlantic, while it has occurred as a straggler off the coasts of New England in North America, and also on the British Islands.

The first record of the species appears in Parkinson's Drawings in the Banksian Library in the British Museum. Sydney Parkinson accompanied Sir Joseph Banks as artist, during Captain Cook's first circumnavigating voyage. His thirteenth plate represents this Petrel, which was obtained on the $23 \mathrm{rd}$ December, 1768 , in Lat. $37^{\circ} \mathrm{S}$., and was named Procellaria aquorea by Solander, who gave a description of it in his 


\section{MONOGRAPH OF THE PETRELS.}

MSS. notes (Salvin, Orn. Misc. I., p. 238 ; Sharpe, Hi.st. Coll. Brit. Mus., II., p. 175). This name of Solander's was never actually published, and it was left to Latham to describe under the name of the "Frigate Petrel," and afterwards as Procellaria marina.

This species is not infrequent in the seas of New South Wales, Victoria, South and West Australia, Tasmania, and the islands of Bass's Straits. Gilbert found it breeding on the islets off Cape Leeuwin, in December, as well as in the Abrolhos. Mr. A. J. Campbell met with it nesting on Beacon Rock, on the south of Rat Island (Nests and Eggs Austr. Birds, II., p. 872), and records its breeding on several islands in Bass's Straits. The erection of some forts on Mud Island in Port Phillip Bay was supposed to have driven the Petrels away; but at Christmas, 1902, Mr. S. P. Townsend visited the island and found several rookeries still in existence, though they were threatened with extinction by the guano-diggers. The birds are now under Government protection (Townsend, Vict. Nat., XIX., p. 166 ; Le Souef, Emu, III., p. 167).

P. marina is said by Sir Walter Buller (Birds New Zealand, 2nd ed., II., p. 248) to be less common in New Zealand seas than Garrodia nereis. In the Auckland Islands it was met with by the Antaretic Expedition, and a specimen from Enderby Island, presented by Mr. Oakley, is in the British Museum (Salvin, Cat. Birds Brit. Mus., XXV., p. 363). Dr. H. O. Forbes also obtained eggs in the Chatham Islands (Ibis, 1893 , p. 542).

Examples were procured by Macgillivray in the South Indian Ocean (Lat. $37^{\circ} 30^{\prime}$ S., Long. $42^{\circ}$ E.) during the voyage of the "Rattlesnake," and by the "Challenger" on Nightingale Island, one of the Tristan da Cunha group.

During their expedition to Madeira, Mr. Ogilvie-Grant and the Hon. Cecil Baring observed these birds in some numbers round the Salvage Islands, and they afterwards found them breeding on Great Salvage in April, 1895, when they procured a good series of both the birds and eggs. They were also reported to nest in large numbers on the Little Piton. A few specimens have been obtained in the Canary Islands (Hartert, Nov. Zool., VIII., p. 332), and examples from Tenerife are in the collections made by Captain Savile Reid and Mr. E. G. B. Meade-Waldo (Salvin, Cat. Birds, XXV., p. 363). It was found breeding on the Rombos Islands in the Cape Verde Archipelago by Lieut. Boyd Alexander (Ibis, 1898, p. 95).

Two specimens are recorded from the British Islands, one off Walney Island after a severe gale in November, 1890, the other being captured alive on the west coast of the island of Colonsay, also after a heavy gale, on the 1st January, 1897. This specimen is now in the Royal Scottish Museum at Edinburgh (cf. Saunders, Manual Brit. Birds, 2nd ed., p. 735). The species has also been found off the coast of Massachusetts (Ridgway, Mun. N. Amer. Birds, p. 72).

The habits of this Petrel resemble those of others of the group, in that it makes 


\section{PELAGODROMA MARINA.}

no attempt at a nest, and breeds in rat-like holes, extending two or three feet deep. On Mud Island Mr. Townsend found $P$. marina nesting plentifully, and estimated the number of pairs at about five thousand. The old birds did not arrive till after dark, when large numbers came in about ten o'clock, and even later, and Mr. Townsend concluded that, after feeding their young, the parent birds returned to sea again. The food consisted of a pasty matter, in which remains of small shrimps were detected.

Mr. Ogilvie-Grant found that both sexes took part in the incubation, and noticed that a number of the birds had been killed, having been bitten through the nape of the neck, and the eggs sucked by mice, which had penetrated the burrows in the sandy ground.

The eggs are very similar to those of other species of Storm-Petrels, being white, covered at one end with minute grey and mauve spots, frequently forming a zone; there is, however, some variation both in shape and markings, and they are sometimes entirely white. The specimens procured by Mr. Ogilvie-Grant measured:-Axis, 1.35-1.48 inch ; diam., 1.0-1.08.

Adult male. General colour dusky-grey, with obscure dusky edgings to the feathers, the scapulars and wing-coverts rather more dusky and inclining to sootybrown; rump and upper tail-coverts paler and light ashy-grey, contrasting with the back; primary-coverts and quills black, as also the tail, which is scarcely forked, the tail-feathers shaded with grey towards the base ; crown of head dark ashy-grey, slightly contrasting with the dusky-grey of the back; lores and forehead pure white, extending backwards into an indistinct eyebrow, which forms a broad white streak above the earcoverts ; feathers in front of the eye and ear-coverts black; sides of face, cheeks, throat, and under-surface of body pure white, the sides of the neck dull ashy-grey like the mantle ; under tail-coverts white, the longer ones ashy-grey towards the ends, the lateral ones mottled with ashy-grey; axillaries and under wing-coverts pure white, with a few black feathers round the bend of the wings; quills dusky black below, the inner webs dark ashy-grey, the primaries white towards the base ; "bill black; feet black, middle of webs yellow; iris blackish brown" (W. R. Ogilvie-Grant).

Total length, 8.0 inches ; culmen, 0.7 ; wing, 6.8 ; tail, 2.9 ; tarsus, 1.75 ; middle toe and claw, 1.4 .

Adult female. Similar to the male in colour. Total length, 8 inches; culmen, 0.7 ; wing, 6.5 ; tail, 3.15 ; tarsus, 1.8 ; middle toe and claw, 1.45 .

Nestling. Covered with sooty-brown down. The plumage of full-grown young birds is like that of the adults as soon as the down is shed. The grey rump and upper tail-coverts have wavy cross-lines of grey and white, with a white fringe at the end of the feathers. One specimen has the lower flanks and under tail-coverts freckled with greyish bars.

Mr. Ogilvie-Grant states that the series procured by him on Great Salvage Island 


\section{MONOGRAPH OF THE PETRELS.}

showed that the female was slightly larger than the male, and he gives the dimensions as follows:-

o Wing, 5.8-6.6 inches ; tail, 2.85-3.1 ; tarsus, 1.67-1.75.

o Wing, 5.8-6.6 inches ; tail, 3.1-3.2 ; tarsus, 1.75-1.8.

I have not found any great difference in the size of the sexes, my measurements, taken from specimens in the British Museum, being as follows :-

๙ Wing, 6.15-6.8 inches ; culmen, $0.65-0.7$; tail, 2.75 ; tarsus, $1.65-1.75$; middle toe and claw, 1.4-1.45.

o Wing, 6.3-6.5 inches; culmen, 0.7 ; tarsus, $1.75-1.8$; middle toe and claw, 1.35-1.4.

The male and female described above are from the series from Great Salvage Island; the young birds are from Western Australia, all being in the British Museum. The specimen figured is in our collection, and is said to be from New Zealand. 


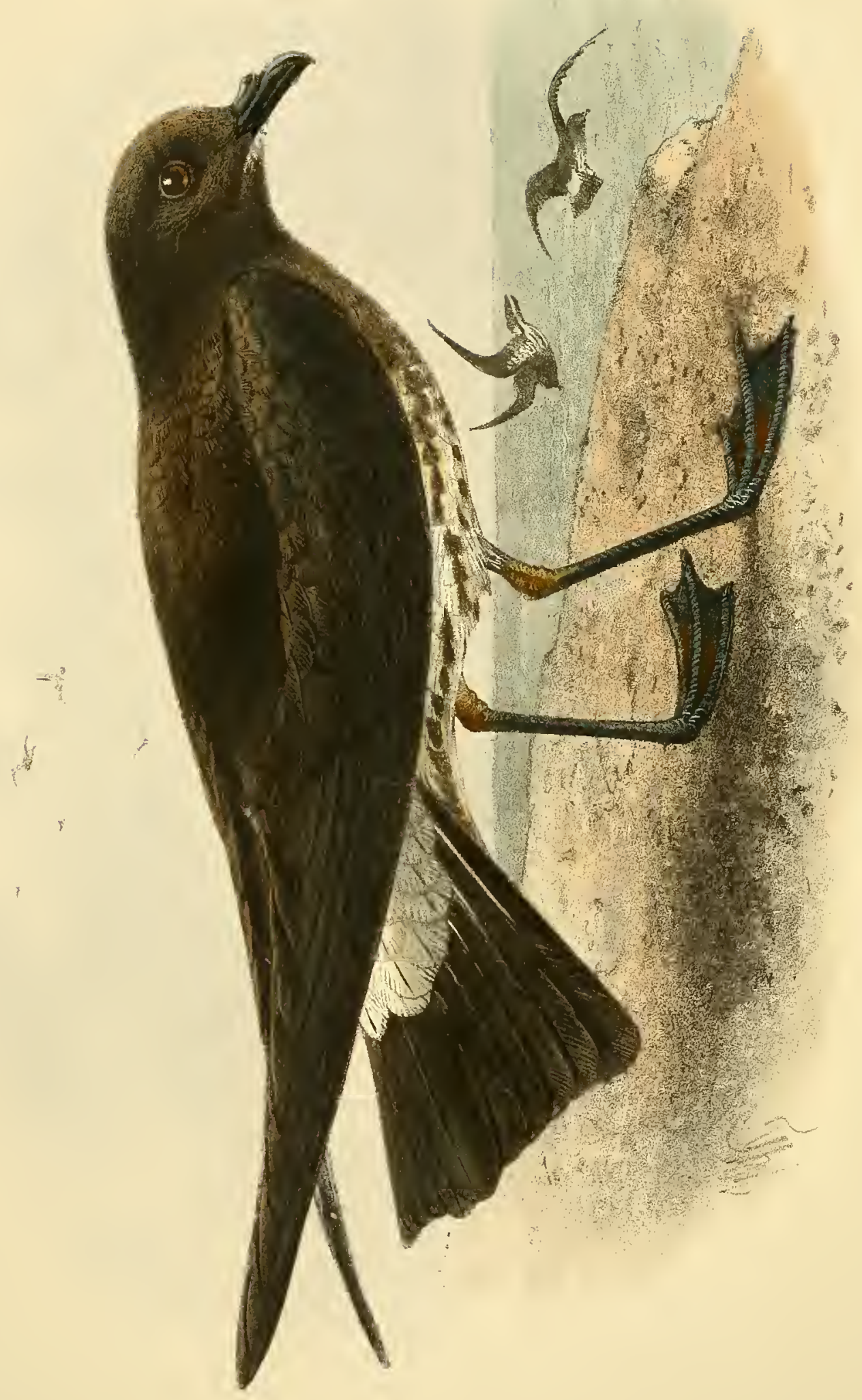




\section{PEALEA LINEATA (Peale). (PEALE'S STORM-PETREL.)}

(Plate 16.)

Thalassidroma lineata, Peale, U. S. Expl. Exp., VIII., pp. 293, 337, Plate 39 (1848). Oceanites lineata, Bp., Consp. Av., II., p. 200 (1856); Coues, P. Philad. Acad., 1864, pp. 83, 91.

Pealea lineata, Ridgway, Auk, III., p. 334 (1886) ; Salvin, Cat. Birds Brit. Mus., XXV., p. 364 (1896).

Fuliginoso-nigra, gutture et pectore summo, dorso concoloribus: gula alba, nigro maculata: corpore reliquo subtus albo, longitudinaliter nigro striolato: supracaudalibus pure albis.

I kNOW of only three specimens of this rare Storm-Petrel in collections. The type is in the U. S. National Museum at Washington, and was procured by Titian Peale at Upolu, in the Sandwich Islands, during the celebrated exploring expedition promoted by the United States. Salvin states that a second specimen is in the Paris Museum, and I found a third in our own National collection, for since Salvin wrote his "Catalogue" an example of Peale's Storm-Petrel has been presented to the British Museum by Mr. G. Carrick Steet, who procured it in the neighbourhood of Banks's Peninsula, New Zealand. This is, however, not the first record of the species from New Zealand seas, for Bonaparte mentions the specimen in the Paris Museum as having been procured in 1829, during the voyage of the "Astrolabe," off East Cape in the North Island.

No notes have been published on the bird, beyond Layard's statement that he saw a small party of these Petrels off Upolu (P. Z. S., 1876, p. 498).

Peale says that this bird was frequently seen within the torrid zone, in the Pacific Ocean. A single specimen was obtained at the island of Upolu from a native, who represented to him that during the breeding season the species lived in holes very high up on the mountains (Cassin, U. S. Expl. Exped. Orn., p. 403). 


\section{MONOGRAPH OF THE PETRELS.}

The following description is taken from the specimen in the British Museum :-

Aduit. General colour above sooty-black, the upper tail-coverts conspicuously white; wing-coverts sooty-black like the back, the greater series somewhat browner and with faint hoary margins; quills and tail-feathers sooty-black, the latter white at the base, the shafts also white at the base; head and neck all round, fore-neck and chest, sooty-black; the throat white, mottled with sooty-black tips to the feathers; remainder of under-surface from the chest downwards pure white, streaked on the breast and sides of the body with black longitudinal centres, widening out towards the ends; abdomen and under tail-coverts white, the latter also with black spots at the ends; axillaries white, as also the under wing-coverts, which have a very broad band of sooty-black round the bend of the wing; "bill and feet, including interdigital membrane, blue-black, without any spots; iris dark brown" (Peale).

Total length, about 7 inches ; culmen, 0.6 ; wing, 5.5 ; tail, 2.7 ; tarsus, 1.3 ; middle toe and claw, 1.1.

The figure in the Plate was drawn from the specimen in the Paris Museum, and Salvin was indebted to Professor Milne-Edwards for the loan of it and several other rare species. 



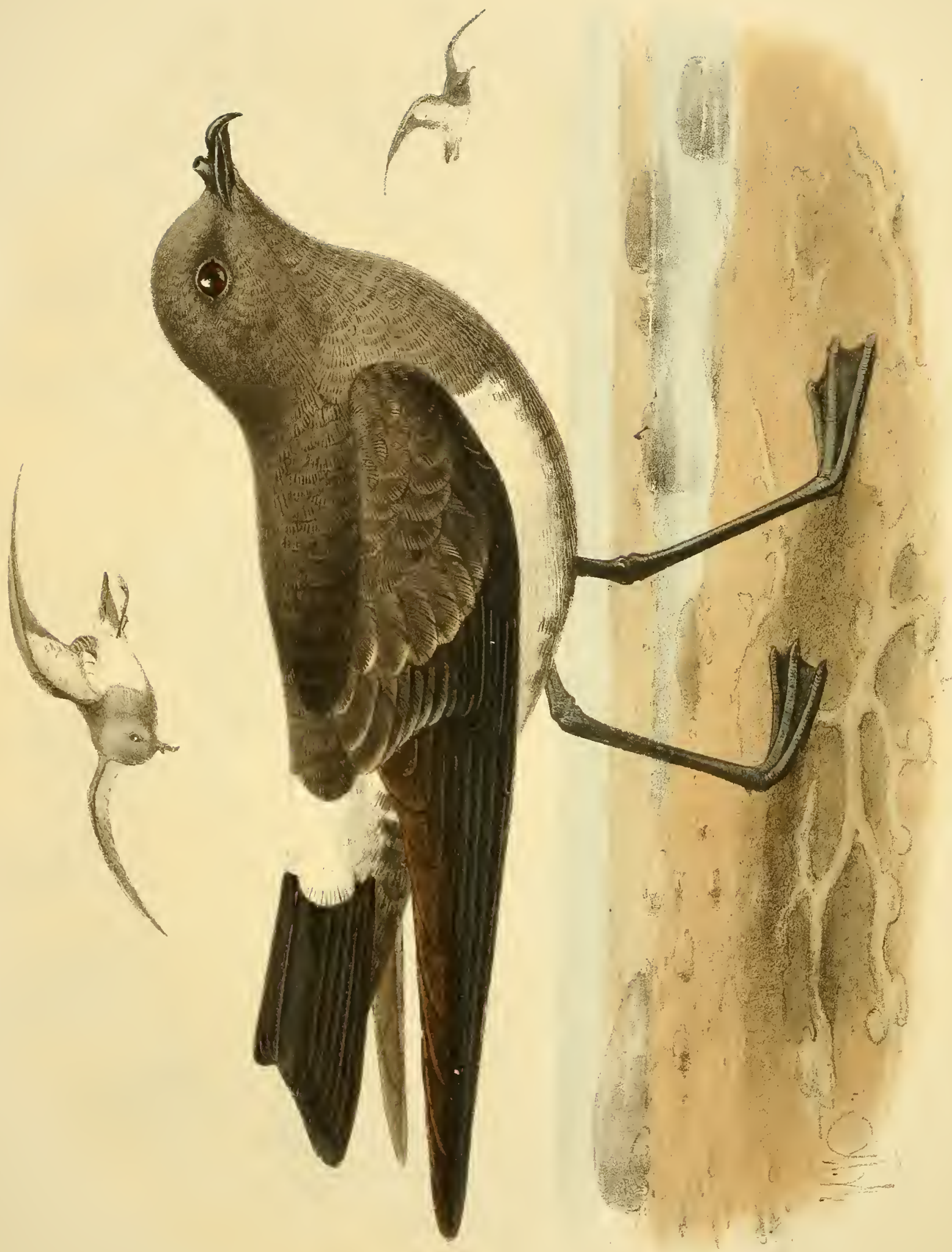

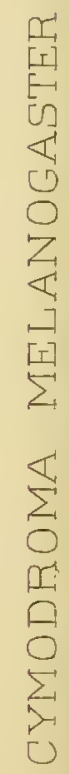




\section{CYMODROMA MELANOGASTER (Gould).}

(BLACK-BELLIED STORM-PETREL.)

\section{(Plate 17.)}

Procellaria grallaria (nec Vieill.), Licht., Verz. Doubl., p. 83 (1823).

Procellaria oceanica (nec Kuhl), Bp., Zool. Journ., III., p. 89 (1828).

Thalassidroma melanogaster, Gould, Ann. and Mag. Nat. Hist., XIII., p. 367 (1844); id., B. Austr., VII., Pl. 62 (1847).

Thalassidroma tropica, Gould, Ann. and Mag. Nat. Hist., XIII., p. 366 (1844).

Fregetta melanogaster, Bp., Consp. Av., II., p. 198 (1856) ; Coues, Pr. Acad. Philad., 1864, pp. 87, 91 ; Gould, Handb. Birds Austr., II., p. 479 (1865) ; Buller, Birds N. Zeal., 2nd ed., II., p. 249 (1888); id., Suppl., Birds N. Zeal., I., p. 99 (1905); Eagle Clarke, Ibis, 1906, pp. 150, 168.

Procellaria melanogastra, Schl., Mus. Pays-Bas, VI., Procell., p. 6 (1863, pt.).

Procellaria tropica, Gray, Handl. Birds, III., p. 104 (1871).

Oceanitis tropica, Sharpe, Phil. Trans., Vol. CLXVIII., p. 130 (1879) ; id., ed. Layard's Birds S. Afr., p. 764 (1884).

Oceanites melanogaster, Pagenstecker, J.B. Hamb. Wiss. Anst., II., p. 18 (1884).

Cymodroma melanogaster, Ridgway, Man. N. Amer. Birds, p. 72 (1887); Salvin, Cat. Birds Brit. Mus., XXV., p. 365 (1896).

Fuliginoso-nigra; pectore et abdomine quoque fuliginoso-nigris: corporis lateribus pure albis.

THIS species, although known to earlier writers and mentioned under different names, as can be seen from the synonymy, was first described as Thalassidroma melanogaster by Gould in his paper on "the family Procellariidae, with descriptions of ten new species" (Ann. and Mag. Nat. Hist., XIII., p. 366, 1844). At the same time he described two other species, T. tropica and T. leucogaster. The latter is evidently the bird now known as Cymodroma grallaria (Vieill.). 


\section{MONOGRAPH OF THE PETRELS.}

Gould's original description of his T. tropica is as follows :--" Head, back, wings, tail, and breast dark sooty-black; chin, under-coverts of the wings, abdomen, flanks, under tail-coverts and a broad crescentic-shaped band across the upper tail-coverts,

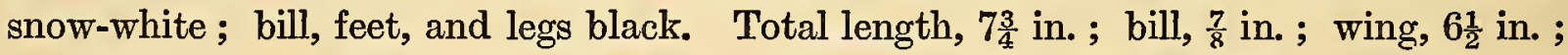
tail, $3 \frac{1}{2}$ in. ; tarsus, $1 \frac{3}{4}$ in. ; middle toe and nail, $1 \frac{1}{4}$ in." The white abdomen would seem to point to $P$. tropica being identical with $C$. grallaria, but then Gould would scarcely have omitted to mention the conspicuous white edgings on the feathers of the back.

Gould further writes of his T. tropica :-“I observed this species in the Atlantic, where it is confined to the equatorial region, being most abundant in the vicinity of the Iine. It is the largest member of the genus with which I am acquainted, and is rendered very conspicuous by the white mark on its throat" (cf. Ann. Nat. Hist., XIII., p. 366). In his folio work on the "Birds of Australia" he does not allude to T. tropica at all, nor does the name occur in his "Handbook," but in both these works he gives the following note under the heading of $C$. grallaria :- "I killed specimens of a nearly allied species within the tropics of the South Atlantic, which differed in being of a larger size, and in having a patch of greyish white on the throat. These differences will doubtless prove it to be a distinct species, and I mention this in order that the two birds might not be confounded by subsequent voyagers or writers on the subject. I have presented a specimen of the larger species, killed by myself, at the Equator, to the British Museum, where it is always accessible for comparison and other scientific purposes."

The example mentioned by Gould is specimen $a$ of Salvin's "Catalogue of Birds" (Vol. XXV., p. 365), and bears the label "North Atlantic, Lat. $6^{\circ} 33^{\prime}$ N., Long. $18^{\circ} 6^{\prime}$ W." The measurements are :-Wing, 6.7 inches ; culmen, 0.55 ; tarsus, 1.6 ; middle toe and claw, 1.15 .

It will be seen that these dimensions differ somewhat from those of C. tropica, given by Gould, and the actual type of the latter species no doubt went to Philadelphia with the rest of his collection; but the specimen in the British Museum may justly be considered a co-type of $C$. tropica, and Salvin has recognised it as such. Gould certainly regarded it in this light, and his intention evidently was to deposit in the National Collection an authentic example of the supposed species from the Equator, but he did not present it under his previous name of $T$. tropica, although there can be no doubt that it is the species which he described under that title in 1844.

This specimen is unquestionably an immature individual of $C$. melanogaster. It is in no case $C$. grallaria, and the scanty edgings of white to the dorsal feathers are but evidences of immaturity; while on the abdomen are some patches of black, also, in my opinion, signs of a young $C$. melanogaster, and clearly showing that it cannot be referred to $C$. graliaria. It is remarkable that Gould makes no allusion to these black patches in the specimen he gave to the British Museum. 


\section{CYMODROMA MELANOGASTER.}

In the folio edition of the "Birds of Australia" Gould says that specimens of $C$. melanogaster were procured by Sir George Grey on his outward voyage to Australia. "off Lagullas Bank," and deposited in the British Museum. In his later work, the "Handbook of the Birds of Australia," he speaks of himself as having met with this species on the 12th August, 1839, "when off Cape Lagullas, on my voyage to Australia," etc.

There is some mistake on Gould's part, for the only specimens presented by Sir George Grey were two examples of $C$. grallaria, received by the Museum in July, 1843, and registered as from "South Australia" (cf. Gray's List of Anseres, p. 161 (1844); Salvin, Cat. Birds Brit. Mus., XXV., p. 367). As most of the specimens presented by Sir George Grey on this occasion were actually from South Australia, these two Petrels were doubtless included under the same heading, and the original labels having been destroyed, as was usual in those early days, the exact record has been lost. I have, however, no doubt that these two specimens from "South Australia" are the actual pair which Gould avers to have been captured by Sir George Grey off the Agulhas Bank, and which are really $C$. grallaria, and not $C$. melanogaster.

Dr. Bowdler Sharpe, recognising that $C$. tropica of Gould was the same as $C$. melanogaster, proposed to substitute for this latter name that of $C$. tropica, as it has priority of a page in the volume of the "Annals." Salvin did not adopt this view, and Dr. Sharpe tells me that he would now oppose such a change, as the name of melanogaster is so widely known and so clearly determined, whereas the name of $C$. tropica carries a certain amount of doubt with it, and has no practical priority, being published at the same time, and in the same number of the "Annals" as C. melanogaster. Concerning the latter name there is no question, and Dr. Sharpe himself has adopted it for the species in the "Report" on the "Southern Cross" collections.

The Black-bellied Storm-Petrel is an inhabitant of the southern area of the globe, and ranges from the seas of New Zealand and Australia to the Indian and Atlantic Oceans, while it also occurs off the coasts of South America, breeding in South Georgia and the South Orkney Islands.

Gould says that this Storm-Petrel was very abundant in the South Pacific and Indian Oceans, particularly off the islands of St. Paul and Amsterdam. He also met with it midway between these islands and Van Diemen's Land (Ann. and Mag. Nat. Hist., XIII., p. 367, 1844).

During the voyage of the "Southern Cross," the late Nikolai Hanson obtained a pair of these birds in Lat. $42^{\circ} 23^{\prime} \mathrm{S}$., Long. $20^{\circ} 32^{\prime} \mathrm{E}$. He says that the species was noticed on the 30th December, when the "Southern Cross" reached the ice pack, but it left the ship before they entered the ice (Sharpe, Rep. Coll. "Southern Cross," p. 142).

Dr. Edward Wilson states that the species was constantly seen in the South Atlantic, during the voyage of the "Discovery," throughout September and October. Again, on 20th October they were exceptionally plentiful, and a few appeared almost 


\section{MONOGRAPH OF THE PETRELS.}

every day until 16 th November (Lat. $61^{\circ}$ S., Long. $140^{\circ}$ E.), when they left as the ship came within sight of the ice, and were not seen again (Nat. Antarc. Exped., II., Zool., Aves, p. 79, 1907).

Sir Walter Buller records $C$. melanogaster as occurring in the seas off New Zealand, specimens being in the Auckland, Nelson, and Canterbury Museums (Birds New Zeal., lst ed., p. 319, 1873). He also states that he saw some of these Petrels off the Chatham Islands during a severe storm.

Mr. A. J. Campbell says that it occurs in the seas of Australia and Tasmania (Nests and Eggs Birds Austr., II., p. 874), and he recorded it as breeding on Cliffy Island, but afterwards found that the supposed eggs were really those of Pelecanoides urinatrix. In the British Museum are specimens of the Black-bellied StormPetrel from Port Essington and the coast of Queensland, from our collection. During the voyage of the "Magenta" from Batavia to Melbourne, it was noticed by Professor Giglioli in Lat. $33^{\circ} 7^{\prime}$ S., Long $101^{\circ} 18^{\prime}$ E., on the 18th April, and thence to Cape Otway, after which it was replaced by P. marina (Vertebr. Faun. Oceano, p. 38).

Several specimens have been procured in the Indian Ocean. The late John Macgillivray obtained one in Lat. $43^{\circ} 20^{\prime}$ S., Long. $41^{\circ} 14^{\prime}$ E. (cf. Salvin, Cat. Birds Brit. Mus., XXV., p. 365) ; and the Earl of Crawford in Lat. $36^{\circ} 57^{\prime}$ S., Long. $40^{\circ} 41^{\prime}$ E., on 15th October, and a second specimen in Lat. $32^{\circ} 36^{\prime}$ S., Long. $58^{\prime}$ E. on the 19th of the same month. Another example from the Bay of Bengal is in the Tweeddale Collection in the British Museum (Salvin, t. c., p. 365).

It is also known from the Cape seas, and Layard says that it is not uncommon off Cape Agulhas, and on the south-eastern coast of the Cape of Good Hope (Sharpe, ed. Layard's Birds S. Afr., p. 764).

A specimen presented to the British Museum by Mr. Howard Saunders from the collection of the late C. J. Andersson, but without any exact information as to locality, was probably obtained off Walfisch Bay, in Damara Land. Mr. T. J. Parkin also met with it in Lat. $39^{\circ} 51^{\prime}$ S., Long. $8^{\circ} 49^{\prime}$ E. (Bull. B. O. C., X., p. 106, 1900).

Dr. Frank Penrose describes an egg taken by Sir D. Gill on Boatswainbird Island, close to Ascension Island (Ibis, 1879, p. 282). Salvin examined this egg and believed it to be that of $C$. melanogaster. It might, perhaps, have been that of Oceanodroma castro, but until birds are procured, it is useless to guess at the identity of the species.

The range of $C$. melanogaster extends to the Equator, for the specimen presented by Gould to the British Museum under the name of $C$. tropica (Lat. $6^{\circ} 33^{\prime}$ N., Long. $\left.18^{\circ} 6^{\prime} \mathrm{W}.\right)$, is, as above recorded, an immature bird of $C$. melanogaster. Macgillivray also procured an example of this Storm-Petrel in Lat. $0^{\circ} 12^{\prime}$ S., Long. $30^{\circ} \mathrm{W}$. (cf. Salvin, Cat., p. 365).

In Kerguelen Island this species was found breeding by the "Challenger" Expedition in Betsy Cove (Salvin, Zool. Voy. "Challenger," II., Birds, p. 14 ; Oates, Cat. Eggs 


\section{CYMODROMA MELANOGASTER.}

Brit. Mus., I., p. 151, Pl. XII., Fig. 2). The Rev. A. E. Eaton procured specimens in Royal Sound, but did not find the nest (Sharpe, Phil. Trans., Vol. CXLVIII., p. 30). Mr. Robert Hall was also unsuccessful in finding the eggs, but believes that the nesting-place was somewhere at the north-west end of Royal Sound; he says that the bird was seen at both ends of the island, but not in the same numbers as the yellow-webbed Wilson's Petrel (Ibis, 1890, p. 21).

Pagenstecker, in his account of the birds of South Georgia, recorded O. melanogaster as breeding on these islands (JB. Hamb. Wiss. Anst, II., p. 18, 1884), but its occurrence so far to the westward suggested a doubt as to its correct identification (cf. Howard Saunders, Antarctic Manual, p. 228). That the record is authentic can now scarcely be questioned, for the Scottish Antarctic Expedition found this Storm-Petrel nesting on the South Orkney Islands, and Dr. Pirie obtained eggs (Eagle Clarke, Ibis, 1906, pp. 150, 168). In describing the collections made by the naturalists of the Scottish Antarctic Expedition, he states that Dr. Pirie was attracted by a low whistling sound proceeding from a crevice in a rock on the east side of Uruguay Cove, Laurie Island, about fifteen feet above the sea. On climbing up he discovered what was apparently a couple of Wilson's Petrels, and he managed to secure the female. Two eggs, badly broken in the endeavour to capture the birds, were found near the mouth of the crevice, one of them obviously of a previous season, the other deeply incubated. No other birds were noticed, though search was made for the male, which had escaped.

An egg was procured by the "Challenger" Expedition from the Falkland Islands, and is now in the British Museum.

Off the coast of the South American continent this Petrel was observed by Professor Giglioli during the voyage of the "Magenta," in Lat. $38^{\circ} 22^{\prime}$ S., Long. $47^{\circ} 42^{\prime} \mathrm{E}$., on the 7 th February, 1866, five days from Montevideo, when it followed the ship till the 10th April, and again from the Straits of Magellan to Montevideo, becoming less frequent as the latter town was neared (Faun. Vertebr. Oceano, p. 168).

Four eggs are in the British Museum. One from the "Challenger" Expedition, obtained in Kerguelen Island, is dull white, with a faint pinkish shade at one end, sprinkled with dots of the same colour, which are also seen over the rest of the egg; there is a slight indication of purplish dots, which are, however, scarcely perceptible: axis, 1.45 inch; diam., 1.03. The Falkland Island specimen is very long and thin, and measures 1.25 inch by 0.73 ; the scarcely perceptible markings are of a dull purplish grey. Two eggs bequeathed to the Museum by the late Philip Crowley are said to have been taken by Mr. H. Cole in the Chatham Islands. They are pure white, with reddish dots sparsely distributed over the egg, but more closely collected at one end, where a few black dots are interspersed, and there is an appearance of underlying purplish-grey spots, not very distinctly indicated. Axis, 1.25 inch ; diam., 1.0. 


\section{MONOGRAPH OF THE PETRELS.}

Adult male. General colour above sooty-black, with a strongly indicated gloss of leaden-grey; the wing-coverts sooty-brown, and with faint evidences of hoarygrey margins at the ends of the feathers; lower rump and upper tail-coverts white, forming a broad band; primary-coverts, quills and tail black; the outer tail-feathers white at the extreme base, the base of the shaft also white; crown of head and sides of face as well as the throat sooty-black, distinctly shaded with plumbeous-grey, the throat being slightly mottled with white, the lower throat and chest somewhat sooty; centre of the breast and abdomen also sooty-black, as also the under tailcoverts, which have white bases, the lateral ones being white, with some black near the ends of the inner webs ; sides of breast, sides of abdomen, and flanks, pure white; axillaries white; lesser under wing-coverts and the coverts round the edge of the wing sooty-black; median and greater under-wing-coverts pure white; quills dusky-black below, the inner webs inclining to leaden grey; " bill and feet black, as also the webs; iris dark brown" (N. Hanson). Total length, about 7.5 inches; culmen, 0.5 ; wing, 6.4 ; tail, 2.7 ; tarsus, 1.5 ; middle toe and claw, 1.1.

Adult female. Similar to the male. Total length, about 7.0 inches; culmen, 0.5 ; wing, 6.5 ; tail, 2.75 ; tarsus, 1.4 ; middle toe and claw, 0.95 .

Young birds have the chin more or less mottled with white, and have a few blacktipped feathers on the breast and abdomen, as well as some greyish-white fringes to the dorsal feathers.

As Salvin remarks, the amount of white on the throat varies in extent. Most specimens have the chin mottled with white, but in very old birds it is entirely black, like the rest of the throat and chest.

The series in the British Museum measures as follows :-

$\delta$ ad. Wing, 6.4-6.7 inches; tarsus, 1.5-1.55; middle toe and claw, 1.1-1.15.

\% ad. Wing, 6.5-6.7 inches; tarsus, 1.45-1.7; middle toe and claw, 0.95-1.15.

The descriptions of the adult male and female are taken from a pair of birds collected by Nikolai Hanson during the voyage of the "Southern Cross," and the figure is taken from a specimen from Port Essington in our own collection. 



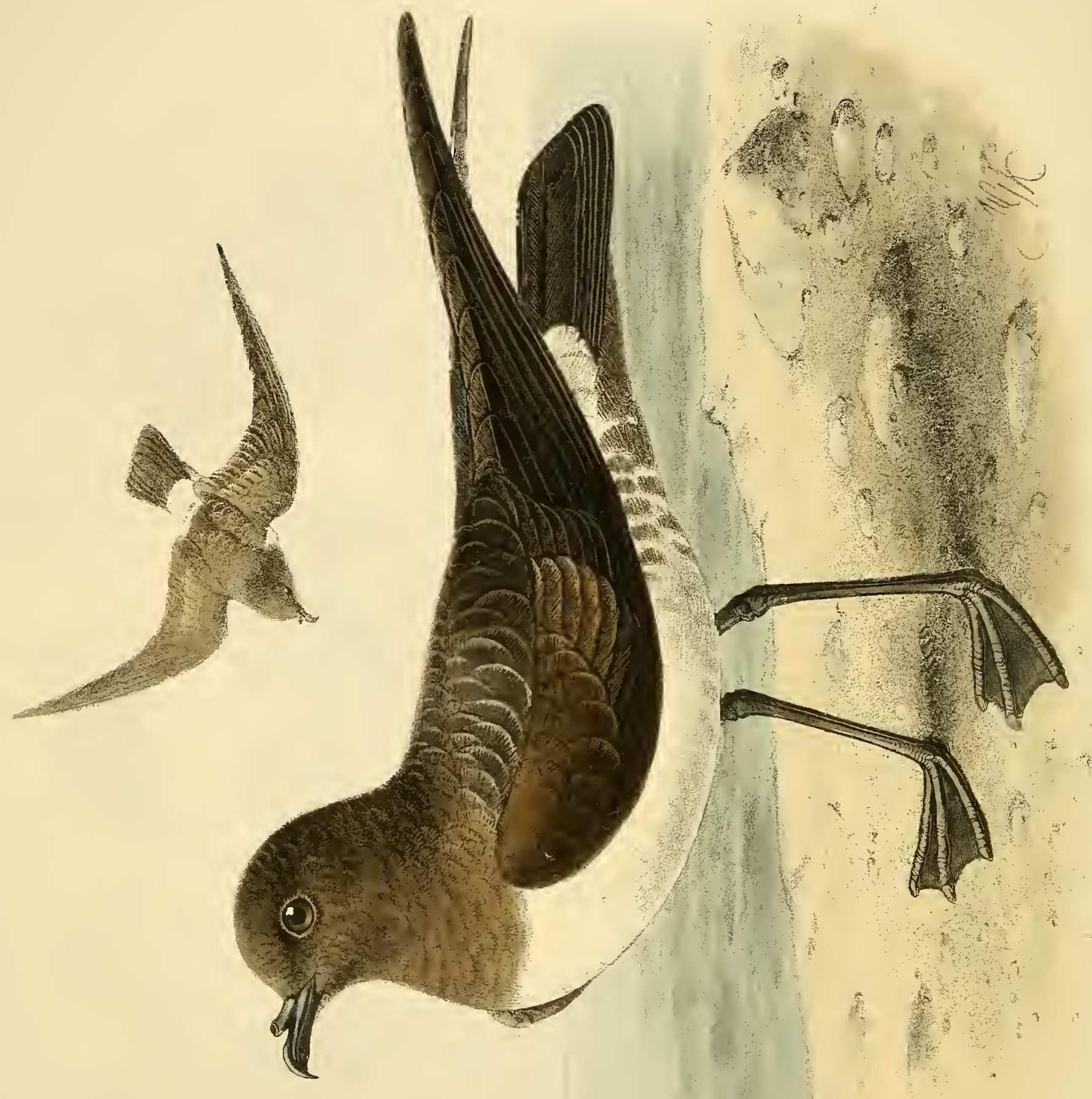

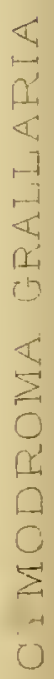




\section{CYMODROMA GRALLARIA (Vieill.).}

(WHITE-BREASTED STORM-PETREL.)

(Plate 18.)

Procellaria grallaria, Vieill., N. Dict. d'Hist. Nat., XXV., p. 418 (1817).

Oceanites grallaria, Keys and Blas., Wirb. Eur., p. 93 (1840).

Procellaria fregatta (nec Linn.), Kuhl, Monogr. Procell., p. 138, Pl. 10, Fig. 3 (1820; ex Banks, Icon. Ined., Pl. 14.)

Procellaria fregata, Forst., Descr. Anim., p. 180 (1844).

Thalassidroma leucogaster, Gould, Ann. and Mag. Nat. Hist., XIII., p. 367 (1844) ; id.,

Birds Aust., folio, VII., Pl. 63 (1847).

Thassidroma fregetta (nec Linn.), Gray, List Anseres, Brit. Mus., p. 161 (1844).

Fregetta grallaria, Bp., Consp. Av., II., p. 197 (1856).

Thalassidroma segethi, Philippi and Landb., Arch. Nat., 1860, p. 282.

Oceanites segethi, Coues, Pr. Acad. Philad., 1864, p. 84.

Fregetta grallaria, Ridgway, Pr. U. S. Nat. Mus., III., p. 210 (1880).

Oceanitis leucogaster, Sharpe, ed. Layard's Birds S. Afr., p. 764 (1884).

Cymodroma grallaria, Ridgway, in Baird, Brewer and Ridgway, Water Birds N. Amer.,

II., p. 419 (1884); Salvin, Cat. Birds Brit. Mus., XXV., p. 366 (1896): Sharpe,

Hist. Coll. Brit. Mus., Aves, p. 175, 1907.

C. melanogastri similis, sed abdomine omnino albo, minime medialiter nigro, et notæi plumis griseo-albo marginatis, distinguenda.

THIS species is very closely allied to C. melanogaster, but has always a white belly and white margins to the feathers of the back. As the young of $C$. melanogaster also show white fringes to the dorsal feathers, Dr. Bowdler Sharpe has suggested that C. grallaria might be the young of $C$. melanogaster, before the black appears on the centre of the breast and abdomen. Salvin, however, did not endorse this view.

According to the evidence at present before me, I am inclined to agree with Salvin in separating the two species, for $C$. grallaria never shows any black on the abdomen, and all the white-banded specimens in the British Museum have the appearance of being adult birds. It seems, therefore, that the white edges to the dorsal feathers are a 


\section{MONOGRAPH OF THE PETRELS.}

sign of adult plumage in C. grallaria, and of juvenile plumage in $C$. melanogaster. In one specimen of $C$. grallaria from the South Indian Ocean in the British Museum (Lat. $37^{\circ} 30^{\prime}$ S., Long. $42^{\circ}$ E.-Macgillivray; specimen " $a$ " of Salvin's Catalogue, p. 367), the throat is white, and the bird has very few white margins to the dorsal feathers, but there is no sign of any black on the belly.

Gould calls attention to the fact that $C$. grallaria has shorter toes than C. melanogaster. I find this to be the case with the specimens in the British Museum; for in C. melanogaster the middle toe and claw vary from 0.95 inch to 1.2 inch, but never exceed 0.9 in $C$. grallaria.

A specimen from St. Ambrose Island obtained by Dr. Coppinger, shows only a slight trace of white fringes to the dorsal feathers, but the breast and abdomen are pure white without any trace of black. This seems to indicate that the white bars disappear more or less in fully adult birds, but that the belly remains white at all ages.

C. grallaria has not so extensive a range as C. melanogaster, but is, nevertheless, widely spread over the southern seas. Gould writes (Handb. Birds Aust., II., p. 480) :"I observed it to be very generally distributed over the South Indian Ocean, but I have reason to believe that it ranges over all the temperate latitudes between the Cape of Good Hope and Cape Horn, and it is not unlikely that it may inhabit similar latitudes in the South Pacific."

Mr. A. J. Campbell considers it to be a scarce species in Australian waters, but he records it as occurring off the coasts of Southern Queensland, New South Wales, Victoria, South and West Australia, and Tasmania, but it has not been found nesting on any of the Australian Islands, and, indeed, the breeding-place is as yet unknown (cf. Campbell, Nests and Eggs Aust. Birds, II., p. 875). Macgillivray observed C. grallaria near Orangerie Bay in S.E. New Guinea.

From New Zealand this bird has not yet been recorded, but Forster obtained a Storm-Petrel off Otaheite in 1773, which he referred to $P$. fregata, but the description best suits the present species, though no mention is made of the white bars on the back. During the voyage of the "Challenger," five specimens were obtained in the South Pacific Ocean on the II th November, 1875 , when the ship was about Lat. $37^{\circ} 29^{\prime}$ S., Long. $83^{\circ} 7^{\prime} \mathrm{W}$.

Dr. Edward Wilson says that on the voyage of the "Discovery" there were several in the wake of the ship on the 18th September, 1901, and in the Southern Indian Ocean on the 24th September in Lat. $37^{\circ} \mathrm{S}$., Long. $8^{\circ} \mathrm{W}$., but none were seen in the winter months on the voyage home, either in the South Pacific or Atlantic (Nat. Antarctic Exped., II., Zool., p. 80, 1807).

Of the two specimens obtained by Sir George Grey off the Agulhas Bank, I have already spoken in my article on $C$. melanogaster, and have expressed my belief that these two birds have been wrongly registered in the British Museum "Catalogues" as from South Australia. 


\section{CYMODROMA GRALLARIA.}

Mr. Layard refers to the specimens obtained by Sir George Grey, and says that the only one which fell under his notice was procured by Commander L. A. Beardslee, of the U. S. Navy, and captured on board his ship, the "Aroostook," about 300 miles to the westward of the Cape, in May, 1867 (Sharpe, ed. Layard Birds S. Afr., p. 764.) No example has as yet been met with on Kerguelen Island, but it was recorded for the first time from Gough Island by the naturalists of the Scottish Antarctic Expedition. Although Mr. Eagle Clarke (Ibis, 1905, p. 26) and Dr. Bruce (Pr. Fourth Inter. Orn. Congr., p. 273, 1907) have both stated that the species has not been recorded from Tristan da Cunha, Mr. Nicoll found it in that group of islands (Tbis, 1906, p. 675).

Professor Giglioli says that, during the voyage of the "Magenta," C. grallaria was seen between Callao and Valparaiso, for three days, replacing Oceanites. In November it was observed off Juan Fernandez, and on the 6 th of that month was also met with in Lat. $39^{\circ} 5^{\prime}$ S., Long. $79^{\circ} 43^{\prime}$ W. (Faun. Vertebr. Oceano, p. 38). Dr. Coppinger, during the voyage of the "Alert," procured a specimen off St. Ambrose Island on the 20th July.

This Petrel has also been known to occur incidentally off the coast of Florida (A. O. U. Checkl., 1886, p. 106).

According to Gould (Handb. Birds Aust., p. 480) the White-bellied Storm-Petrel is a fine and powerful bird. Like the other members of the genus, it feeds on mollusca, the spawn of fish, and any kind of fatty matter that may be floating on the surface of the ocean.

Dr. Wilson, who was naturalist to the "Discovery," says that he continually saw these little Petrels "dropping to touch the water with one foot, and steadying themselves while they daintily took their minute crustacean food from the surface of the water" (Nat. Antarctic Exped., II., Zool., p. 80).

Adult male. Similar to $C$. melanogaster, but easily distinguished by the hoarywhite margins to the dorsal feathers; the breast and belly pure white; the under tail-coverts black, white at base and fringed with white at the tips, the central coverts entirely black. Total length, 7.4 inches; culmen, 0.5 ; wing, 6.5; tail, 3.0 ; tarsus, 1.4 ; middle toe and claw, 0.8.

Adult female. Similar to the male, and having the belly pure white and the dorsal feathers fringed with white. Total length, 6.6 inches; wing, 6.5.

The specimens in the British Museum give the following measurements :-

$\delta$ Wing, 6.5 inches; tarsus, 1.4 ; middle toe and claw, 0.8 ; culmen, 0.5 .

4 Wing, 6.1-6.5 inches; tarsus, 1.4-1.5; middle toe and claw, 0.85-0.9; culmen, 0.5 .

The descriptions are taken from a pair of birds in the British Museum from the South Pacific Ocean. The figure is drawn from a specimen in our own collection, the locality being unknown. 


\section{CYMODROMA ALBIGULARIS (Finsch). \\ (WHITE-THROATED STORM-PETREL.)}

(Plate 19.)

Fregetta tropica (nec Gould), Bp., C. R., XLI., p. 1112 (1855) : id., Consp. Av. II., p. 197 (1856).

Procellaria torquata (nec Macgill.), Gray, Handl. Birds, III., p. 104 (1871).

Thalassidroma albigularis, Macgill. MSS.

Procellaria albigularis, Finsch, P. Z. S., 1877, p. 722.

Fregetta albigularis, Salvin, P. Z. S., 1879, p. 130; Oates, Cat. Eggs Brit. Mus., I., p. 151, Pl. XII., Fig. 1 (1901).

Cymodroma tropica, Ridgw., Man. N. Amer. Birds, 1887, p. 72.

Cymodroma albigularis, Salvin, Cat. Birds Brit. Mus., XXV., p. 367 (1896).

Major : cauda valde furcata: fascia uropygiali angusta alba; gastræo albo, torque pectorali brunneo.

The first mention of this Petrel is by Bonaparte, in his paper on the birds of the Marquesas Islands in the "Comptes Rendus" (Vol. XLI., p. 1112), but he erroneously identified it with $P$. tropica of Gould. Dr. Finsch next named the species $P$. albigularis from a specimen procured at Kandavu, in the Fiji Archipelago, by the late Dr. Theodor Kleinschmidt; it was taken on the nest on the 10th September, 1876. 


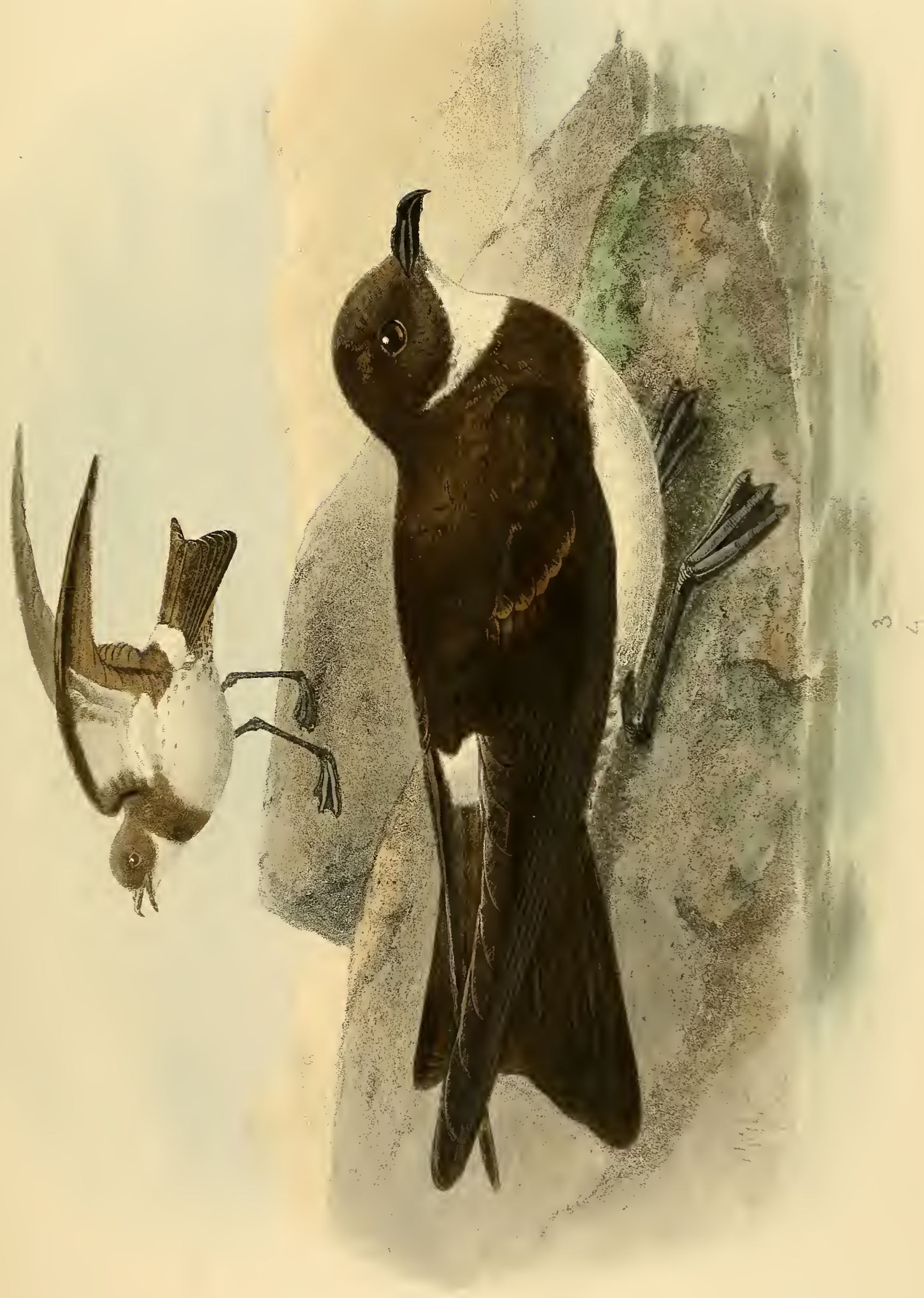





\section{CYMODROMA ALBIGULARIS.}

Macgillivray sent home examples from the New Hebrides, in 1860, to which he attached the MSS. name of Thalassidroma albigularis, a title which Dr. Finsch had adopted without being aware of Macgillivray's suggestion.

In addition to its greater size, $C$. albigularis differs from the two foregoing species in having a strikingly forked tail, and a brown collar across the fore-neck, the throat and rest of the under-surface being pure white.

The species was discovered by the late John Macgillivray on the island of Aneiteum, in the New Hebrides, where it was presumably not uncommon, as he forwarded several specimens to Europe, four of them being now in the British Museum.

Mr. J. J. Lister also records this Storm-Petrel from the Phœnix Islands. He writes (P.Z.S., 1891, p. 295) :- " During the middle of the day there were few of these birds to be seen, but towards sunset, before we left the island, they came in in considerable numbers. I watched one of them beating backwards and forwards over a sandy tract, sparsely covered with grass, in which they make their burrows. It was some time, before the bird found his home and settled down. I caught one as it was disappearing. On putting my arm into the burrow I found a second bird at the extreme end, which was just as far as I could reach. I found no eggs in the burrows, but on opening one of the birds that I obtained, I found an egg, ready to be laid, in the oviduct. This egg measures 1.54 inch in length, and 1.12 inch in breadth. It is of a creamy white, with minute spots profusely sprinkled at the larger end, but sparsely over the remainder; those of the deeper layers are pale purple, the superficial ones reddish-brown. The sandy tract above-mentioned contained a large number of burrows, so that, on walking over it, the ground frequently gave under foot."

Adult male. Sooty-black, the greater wing-coverts a little paler; upper tailcoverts short, white, forming a narrow transverse band across the rump; throat and abdomen, white; a broad præ-pectoral band, brown; a few blackish spots or streaks on the flanks; under wing-coverts and axillaries white, the latter with dusky shaft-streaks; outer under wing-coverts sooty-brown round the edge of the wing; bill and legs black. Total length, about 8.75 inches; central rectrices, 3.25 ; lateral rectrices, 4.25 .

The five specimens in the British Museum measure as follows:-

Three males : culmen, $0.65-0.7$ inch; wing, $7.6-7.9$; tarsus, $1.8-1.85$; middle toe and claw, 1.2-1.3.

Two females: culmen, $0.6-0.7$ inch; wing, $7.8-8.0$; tarsus, 1.8 ; middle toe and claw, 1.25-1.35. 


\section{MONOGRAPH OF THE PETRELS.}

The blackish streaks on the side of the body vary in intensity, but are never entirely absent. Sometimes they are very broad, at others they are reduced to hairlike shaft-lines. Occasionally, in addition to streaks, there are black spots on the flank-feathers, which have sometimes sub-terminal bars of black.

The specimens described are all in the British Museum, the bird figured being one of Macgillivray's from Aneiteum, formerly in our own collection. 



$$
x
$$




\title{
25. CYMODROMA MCESTISSIMA (Salvin).
}

\section{(SAMOAN STORM-PETREL.)}

\author{
(Plate 20.)
}

Fregetta mostissima, Salvin, P. Z. S., 1879, p. 130 ; Wiglesw., Aves Polyn., p. 79 (1891). Cymodroma moestissima, Salvin, Cat. Birds Brit. Mus., XXV., p. 367 (1896).

Fuliginosa, concolor : albedine nulla insignis.

THE uniformity of colour is the distinguishing character of this Storm-Petrel, which fact Salvin emphasized by the specific name he bestowed on it. The type-specimen was sent to us from the Samoan Islands by the Rev. T. Powell, who states that it is found on all the islands of the group. The native name is said to be "Seu-ta-peau."

It must be a species difficult to procure, for, so far as I know, no second specimen has been secured since Salvin described the type, nearly thirty years ago.

The following is Salvin's description in the "Catalogue of Birds" (p. 367) :-

Adult: Sooty-black, nearly uniform, the wings and tail a little blacker; no white markings whatever; bill and legs black. My measurements of the type differ slightly from those of Salvin, being as follows:-Total length, about 9.5 inches; wing, 8.3 ; culmen, 0.7 ; tarsus, 1.85 ; middle toe and claw, 1.35 .

The figure in the Plate has been drawn from the type-specimen now in the British Museum. 


\title{
26. PUFFINUS LEUCOMELAS (Temm.).
}

\author{
(STREAKED SHEARWATER.)
}

(Plate 21.)

Procellaria leucomelas, Temm., Pl. Col., V., pl. 587 (1836) ; Schl., Mus. Pays-Bas, VI., Procell., p. 24 (1863).

Puffinus leucomelas, Lesson, Compl. Buff. Ois., p. 711 (1838) ; Salvad., Orn. Papuasia, III., p. 461 (1882) ; Salvin, Cat. Birds Brit. Mus., XXV., p. 370 (1896).

Thiellus leucomelas, Bp., Compt. Rend., XLII., p. 769 (1856).

Nectris leucomela, Bp., Consp. Av., II., p. 203 (1856).

? Procellaria leucoptera, Musschenbroek, Nat. Tijdsk. Nederl. Ind., XXXVI., p. 379 (1876).

Cauda longa, cuneata : notæi plumis brunneis, albo marginatis : pilei plumis nigris, albo marginatis, quasi nigro striatis.

THIs Shearwater is easily recognised by its plumage, which is more variegated than is usual in the genus Puffinus, the head being streaked or spotted with black and white.

The range of $P$. leucomelas extends from Corea and the Japanese Islands, south to the Malayan Archipelago and New Guinea. Its breeding-place has not been discovered, but it must be somewhere in the North Pacific.

The Howard Saunders Collection in the British Museum contains a specimen from Port Hamilton, in Corea, obtained by Mr. G. Stephen in May, 1885; and numerous examples from the Japanese Islands are in the NationalCollection. The Seebohm Bequest added to the Museum a good series of $P$. leucomelas from Yokohama, obtained by the late Harry Pryer, and from Hakodate, collected by Henson (Seebohm, Ibis, 1884, p. 176) and by Blakiston, on the 19th of May, 1880 (Salvin, Cat. Birds Brit. Mus., XXV., p. 370$)$.

Temminck described this Shearwater from specimens sent to the Leyden Museum by Mr. Berger, who stated that it was common in the seas of Japan. Professor Giglioli states that during the voyage of the "Magenta" this species followed the vessel continuously from the 26 th of June, 1866 , in Lat. $29^{\circ} 1^{\prime}$ N., Long. $126^{\circ} 56^{\prime}$ E., 


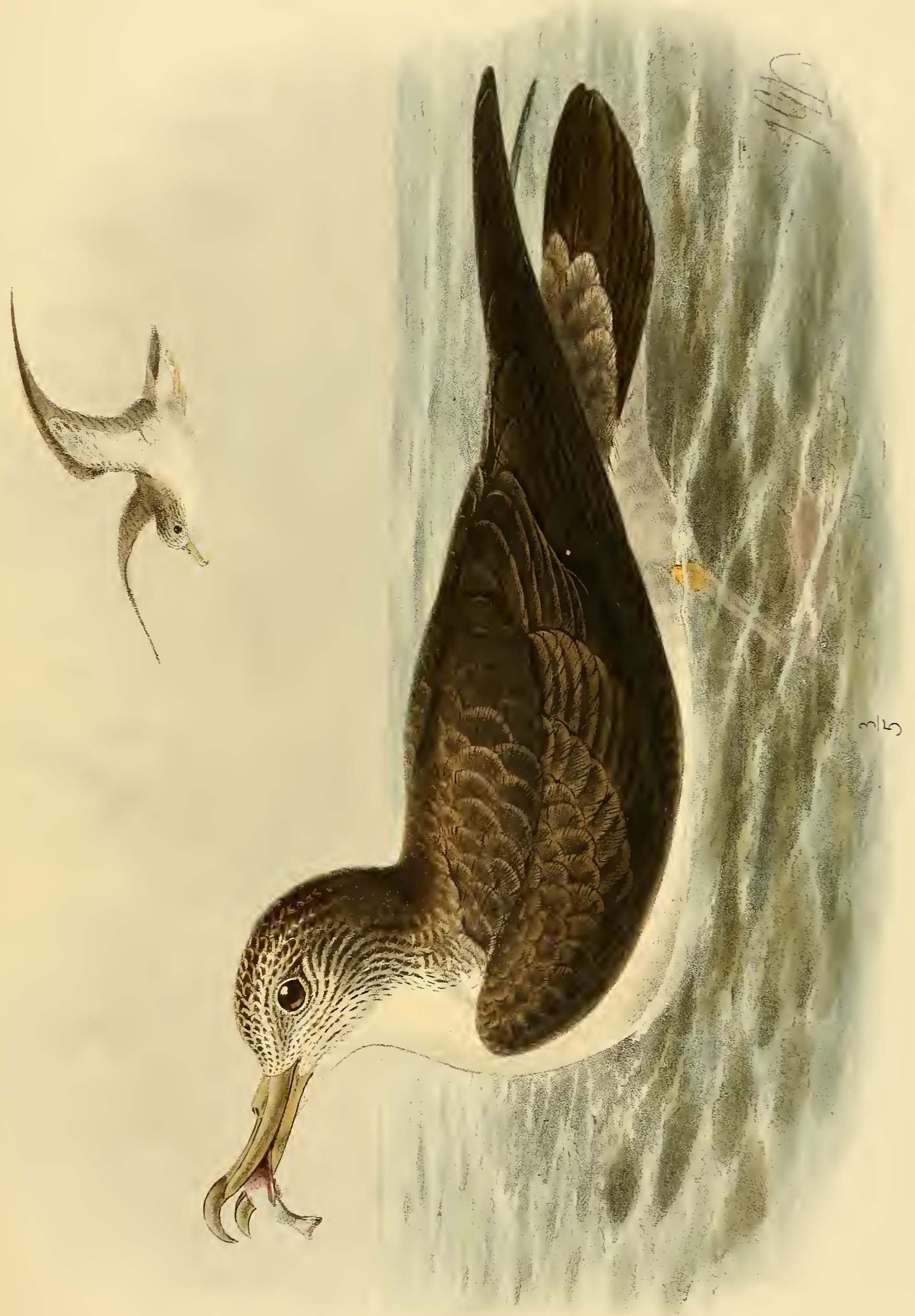

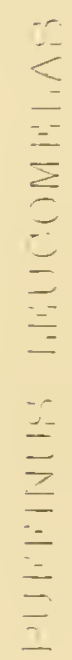





\section{PUFFINUS LEUCOMELAS.}

to the entrance of the Gulf of Yezo. It was plentiful among the islands of Iwoga-Shima, Yarubu-Shima, and Tanega-Shima, to the south of Kiusiu (Faun. Vertebr. Oceano, p. 33).

It will be noticed that the above records refer to the occurrence of $P$. leucomelas in Corea and the Japanese Islands in the months of May and June, and from the numbers observed by Professor Giglioli at the end of the latter month, we may infer that it was breeding in these northern islands.

To the southward this Shearwater occurs abundantly off the coasts of China during the period of migration. Thus David speaks of a Petrel, dark brown above and pure white beneath, which he observed in numbers off the coast of Shantung in June, 1868. He also noticed the same bird in the seas off Che-kiang (David and Oust., Ois. Chine, p. 515). In the British Museum are further specimens presented by Mr. C. B. Rickett, who procured them off Fohkien in July, 1896, and between Shanghai and Foochow in November of the same year.

A single example has been recorded from the Philippine Archipelago, having been obtained by Cuming at Cataguan, in southern Luzon (Gray, List Anseres Brit. Mus., p. 160); and Mr. W. B. Pryer obtained a specimen from Sandakan in north-east Borneo (Sharpe, P. Z. S., 1881, p. 800).

Dr. Pleske records the species from Ternate, in the Moluccas (Bull. Acad. St. Petersb., XXIX., p. 539), and Bernstein obtained a specimen at Morotai (Morty Island). Dr. Otto Finsch also mentions it from Buru (Salvad., Orn. Papuasia, III., p. 461).

According to Dr. A. B. Meyer and Mr. Wiglesworth (Birds, Celebes, II., p. 913), a specimen was obtained by Von Rosenberg, probably on the Gorontalo coast, in 18631864, and two more, from the same traveller, are said by Dr. Büttikofer to be in the Leyden Museum. Musschenbroek informed Dr. Meyer that he obtained an example between Manado and Kwandang, in the Minahassa, but as he speaks elsewhere (Nat. Tijdsk, Nederl. Ind., XXXVI., p. 379, 1876) of a Procellaria leucoptera which seems to relate to the same specimen, the authors of the "Birds of Celebes" were unable to determine which species was really concerned in this case.

Many examples have been sent from New Guinea and the adjacent Papuan Islands. Dr. Finsch mentions one from Amboyna, and the British Museum has two from Dutch New Guinea, obtained from Mr. Van Duivenbode, and similar examples are in the Rothschild Museum at Tring. Dr. A. B. Meyer noticed P. leucomelas near Dorei (Ibis, 1879, p. 144), and Dr. Beccari at Dorei-hum (Salvad., Orn. Papuasia, III., p. 461). The Hon. Walter Rothschild also possesses a specimen from Constantine Harbour, obtained by Mr. Kubary, and Count Von Berlepsch has another from Finsch Harbour, procured by Mr. B. Geisler. Dr. Hübner also met with the bird on Duke of York Island, where, he says, the native name is "Kitai" (Finsch, P. Z. S., 1879, p. 16).

The Cockerell Collection, which I presented some years ago to the British Museum, contains a specimen said to have been procured in north-east Australia, but although 


\section{MONOGRAPH OF THE PETRELS.}

there is no reason why this wide-ranging species should not occur there, the record has never since been confirmed, and, as several birds from the Aru Islands were included by Mr. Cockerell in his Australian collection, it is just possible that the locality for his example of $P$. leucomelas was incorrect, and that it really came from the above islands.

Count Von Berlepsch has very kindly sent me for examination his specimen from Finsch Harbour. He considers it to be distinct from true $P$. leucomelas, and points out the following differences between the Japanese and New Guinea birds, especially the smaller size and weaker bill, the latter being paler and yellower laterally in the Finsch Harbour example. The wings and tail are also somewhat shorter, and the feet are smaller. The black stripes on the sides of the head and neck are narrower, and the black spots on the forehead smaller. The wing in this specimen measures 11.8 inches in length, and the culmen 1.8 inch.

These dimensions are certainly rather small, and the bill is more slender than in typical Japanese examples. In all Petrels, however, according to my experience, there is considerable variation in size, and the specific differences pointed out by Count Von Berlepsch do not hold good when compared with the large series which I have examined in the British and Rothschild Museums, the measurements of which are as follows :-

Japan.-Wing, 11.7-13.5 inches ; culmen, 1.9-2.1.

New Guinea.-Wing, 12.5-13.0 inches ; culmen, 1.9-2.1.

Cataguan.-Wing, 10.7 inches; culmen, 2.0.

Sandakan.-Wing, 12.4 inches; culmen, 1.8.

Finsch Harbour.-Wing, 11.8 inches ; culmen, 1.8.

The Japanese specimens appear, at first sight, to have larger and heavier bills, and even longer wings, but these dimensions are equalled by those of birds from more southern localities, and it will be seen that the small size of the Finsch Harbour specimen is by no means unique. I am, therefore, unable to find any characters to show that the New Guinea bird is separable from true $P$. leucomelas, and there can be but little doubt that the Shearwater found in New Guinea is only a migrant from Japan.

So far as I am aware, no notes on the habits of the present species have been published.

Adult. General colour above dark brown, almost uniform on the mantle, the feathers of the back and scapulars being fringed with white, and with a pale sub-terminal bar on most of the feathers; rump and median upper tail-coverts dark brown, with very faintly indicated whitish fringes; the longer upper tail-coverts white towards the ends, freckled with brown, and showing a dark heart-shaped mark; wings rather blacker than the back, with only a few whitish fringes on the marginal and greater coverts; quills also blackish, browner on the inner webs; the secondaries with white edges, and white towards the base on the inner web; tail blackish-brown; head white, 


\section{PUFFINUS LEUCOMELAS.}

all the feathers being centred with black, producing a spotted appearance; lores and sides of face, as well as the base of the forehead, white, with narrow streaks of black in front of the eye, a little more distinct on the cheeks and ear-coverts; the hind-neck blackish, with a little white on the edges of the feathers; sides of neck dark brown, mottled with white edgings and bars on the plumage ; entire under-surface of body pure white, with some brown feathers on the sides of the chest; under tail-coverts pure white, with white shafts; axillaries and under wing-coverts pure white, with dark brown lanceolate centres to the marginal coverts; lower primary-coverts brown in the centre, with more or less white on either web, and white towards the base ; quills dark brown below, ashy along the inner webs; "bill dark horn-colour ; feet flesh colour, the outer toe a little darker" (Salvin). Total length about 19 inches ; culmen, 2.1 ; wing, 12.7 ; tail, 5.5 ; tarsus, 2.1 ; middle toe and claw, 2.7.

I have had great difficulty in finding any record of the exact colours of the bill and feet of this species in life. Those quoted from Salvin appear to me to have been taken from the dried skin. Descriptions of the soft parts of this Shearwater do not seem to have been published, if we except the notes given by Temminck. If taken from Burger's MSS. these details seem doubtfully correct, being as follows :- "Bill, clear bluish ; feet, yellowish-grey ; iris, grey."

The present species varies considerably in plumage, and these differences are difficult to account for. Some birds are of nearly uniform colour above, with pale brown edges to the feathers. The upper tail-coverts occasionally have white fringes, but show none of the white mottling noticed in the specimen described above. The head is occasionally almost uniformly brown, with a little white mottling on the forehead. In a few specimens the crown is blackish-brown, mottled with white feathers, some of which have black tips; in these darker specimens the black streaks on the side of the face, and on the marginal wing-coverts, are much broader and more pronounced, while there is a great deal of black on the coverts round the bend of the wing.

Whether these darker birds are young individuals, or very old ones, I have had no means of determining.

The specimen figured in the Plate is that mentioned above as having been obtained by Mr. Cockerell in the seas of north-east Australia; the description has been taken from a Japanese bird in the Seebohm Collection. 


\section{PUFFINUS CUNEATUS, Salvin.}

\section{(SALVIN'S SHEARWATER.)}

(Plate 22.)

Puffinus cuneatus, Salvin, Ibis, 1888, p. 353 (July) ; Rothsch., Avif. Laysan, Part I., p. 47 (1893), II., p. 287 (1900) ; Salvin, Cat. Birds Brit. Mus., XXV., p. 371 (1896) ; Godman, Biol. Centr.-Amer., Aves, III., p. 432 (1904).

Puffinus knudseni, Stejneger, Pr. U. S. Nat. Mus., XI., p. 93 (1888, November). Priofinus cuneatus, Bryan, Key Birds Hawaiian Group, p. 12 (1901).

Cauda longa, cuneata: notæo fere concolori, fuliginoso-brunneo: tectricibus alarum dorso concoloribus : gastræo albo, interdum grisescente.

THIs species was described by Salvin in July, 1888, from two specimens obtained by Mr. H. J. Snow in Krusenstern Island, one of a small cluster so named by Kotzebue, belonging to the Marshall Islands, in the Pacific Ocean, about Lat. $10^{\circ} 17^{\prime} \mathrm{N}$., Long. $170^{\circ}$ E. (cf. Salvin, l.c.).

It was afterwards found breeding on Sulphur Island, one of the Volcano Group, by Holst, in June, 1890 (Seebohm, Ibis, 1891, p. 191), and the Hon. Walter Rothschild received specimens from San Dionisio (Lat. $24^{\circ} \mathrm{N}$., Long. $141^{\circ}$ E.), another island of the same group. He has likewise in his collection two examples from the Bonin Islands, collected by Mr. Alan Owston.

In the Hawaiian Islands $P$. cuneatus was met with by Mr. Knudsen, after whom it was named by Dr. Stejneger in November, 1888, a few months after Salvin had described the Krusenstern specimens. As far as I am aware, this bird has only been procured on the island of Kauai, but it doubtless occurs elsewhere in the Hawaiian Archipelago. It was observed by Palmer on all the islands of the Laysan group, with the exception of Midway Island, but in no great numbers, and was breeding in May and June. Mr. Walter Fisher says that it is abundant in Laysan, though not so common as EEstrelata hypoleuca $(A u k, 1903$, p. 386). It encircled the central lagoon of the island, in a ring inside the enormous colony of the $E$ strelata.

The Rothschild Museum contains a specimen procured by Mr. Beck in Lat. $11^{\circ} \mathrm{N}$., 


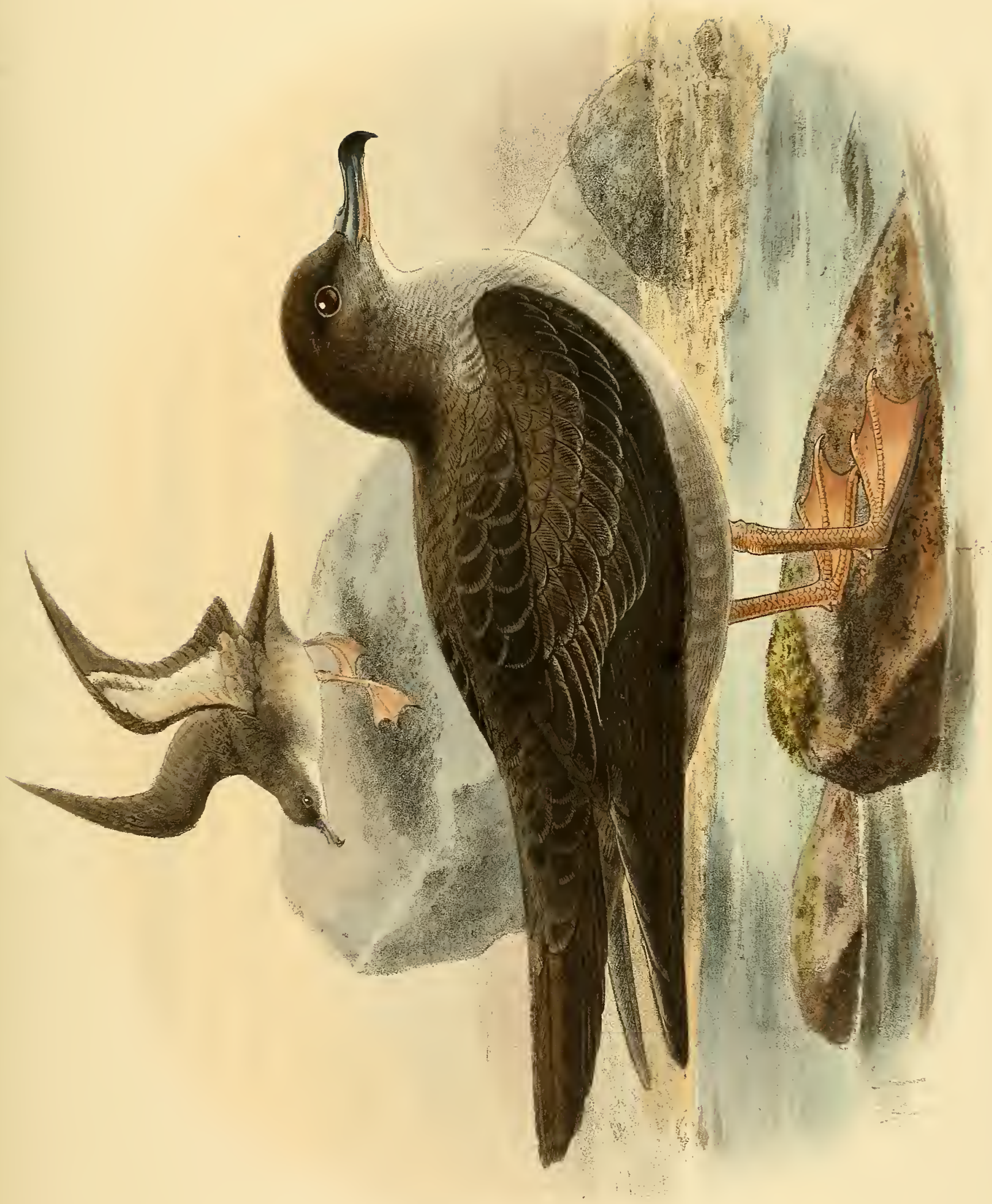





\section{PUFFINUS CUNEATUS.}

Long. $105^{\circ} \mathrm{W}$, , on the 7 th of August, 1903. It is the largest example that has come under my notice, having the following measurements: Wing, 12.2 inches; culmen, 1.7 ; tarsus, 2.0 ; middle toe and claw, 2.45.

Mr. Anthony $(A u k, 1900$, p. 250) relates that, during the months of May and June, off Cape St. Lucas and the Revillagigedo Islands he met with $P$. cuneatus, and a large colony of this Shearwater was nesting on San Benedicto. The record is of special interest, as the species was new to the American Fauna. A fine series of skins was obtained, showing all the intergrades between the white-bellied phase of $P$. cuneatus and the dusky form from the Sandwich Islands, described byDr. Stejneger as P. knudseni. Mr. Anthony further states that he observed this Shearwater at sea near Clarion Island, though at the time of his visit the birds were not nesting; they were not seen west of Rocca Partida ( $A u k, 1898$, pp. 313, 316), nor between Cape St. Lucas, in Lower California, and Socorro and San Benedicto, where they became abundant; the bird was also noted by Mr. Nelson near the Tres Marias Islands (N. Amer. Faun., No. XIV., p. 27).

The low murmuring sound made by the birds was very difficult to locate, but Mr. Anthony eventually found the south end of San Benedicto literally honeycombed with their burrows; in fact, so completely undermined that he frequently sank hip-deep through the surface of apparently solid ground. The birds betrayed their presence by moans and sobs, and when the burrows were opened, each one contained a pair, which fought and bit savagely on being dragged to the light. Their plumage varied considerably, the larger number being dark, but many had a light under-surface. One burrow contained a typical $P$. cuneatus, with pure white under-parts, in company with a dark $P$. knudseni.

The burrows extended about five feet in a horizontal direction along the steep narrow ravines at the southern end of the island, and the pumice rock was so hard in places that the burrows frequently had to be opened with a pickaxe. A little green grass or other vegetation formed the only attempt at a nest, and on this slight structure both the parent birds sat; but there were no eggs, and the condition of the birds gave no indication that the breeding season was at hand, when Mr. Anthony visited the island.

At sun-set the birds ashore would go out to sea, and at the same time large numbers came inland. Thousands of Shearwaters would then be circling about, with a very airy and graceful flight, contrasting with that of $P$. auricularis, which occasionally skimmed through the throng. A bird with white head and dusky body was observed circling several times round the boat, and seemed strongly suggestive of a Heermann's Gull.

On Laysan, Mr. H. C. Palmer found this Shearwater in pairs, and making a rude nest of grass in a burrow in the sand, in which but a single white egg is laid. The latter is elongate in shape, the shell very thin and smooth, but without gloss. 


\section{MONOGRAPH OF THE PETRELS.}

The dimensions of four specimens were as follows :-Axis, 2.45-2.53 inches; diameter, 1.58-1.74.

Adult. General colour above brown, with indistinct ashy-brown margins to the feathers of the mantle, the dorsal feathers and scapulars edged with paler brown or ashy-white, the scapulars being blackish-brown, and contrasting somewhat with the mantle and lower back; rump and upper tail-coverts uniform dark brown, with concealed ashy bases; wing-coverts brown, the greater series with concealed grey bases, turning to white at the extreme base ; outer median-coverts slightly greyer externally and fringed with white at the ends, like the greater series; bastard-wing, primary-coverts, and quills, blackish, the inner secondaries browner and more like the back; tail-feathers blackish-brown; head and hind-neck blackish brown, darker than the mantle; lores and sides of face dark ashy-grey, the ear-coverts browner; throat white, like the rest of the under-surface of the body, with ashy bars and frecklings on the sides of the cheeks and sides of the neck; the fore-neck and chest ashy-grey, a little darker grey on the sides of the body; breast white, faintly shaded with ashygrey, the abdomen more ashy-brown; under tail-coverts dark ashy-brown, the longer ones blackish-brown; axillaries ashy-brown, with slight whitish mottlings at the ends; under wing-coverts white, slightly mottled with ashy-grey near the edge of the wing; marginal coverts ashy-grey; quills dark brown below, with a slight sheen of ashy-grey; "bill light grey, except the upper part from the groove and the hook at tip, which are black, as also the edges of the lower mandible and its hook; tarsi and feet whitish-pink, somewhat dusky on the joints of the under-side; iris pale brown" (Holst MSS.). Total length about 17.5 inches; culmen, 1.65; wing, 11.85 ; tail, 5.4 ; tarsus, 1.9 ; middle toe and claw, 2.35.

Another specimen, or co-type, is in the British Museum, having been presented by the late Henry Seebohm, and, like that described above, was procured on Krusenstern Island by Mr. Snow in the spring of 1883. It differs from the type in being almost entirely white below, with a few ashy frecklings on the hinder cheeks and sides of neck, and with a certain amount of ashy dusting on the sides of the body. Total length about 17.5 inches; culmen, 1.55 ; wing, 11.5 ; tail, 5.2 ; tarsus, 1.95 ; middle toe and claw, 2.2.

A third specimen obtained by Mr. P. A. Holst on Sulphur Island is of the whitebreasted phase, and agrees with the co-type.

Salvin observed that, even in the small series which was at his disposal in 1896 , there was some variation in the colour of the under-surface of the body, one of the typical specimens being pure white, while the other was greyer, "especially over the breast, flanks, and lower abdomen."

The Hon. Walter Rothschild has drawn attention to these differences in his "Avifauna of Laysan." $\mathrm{He}$ was at first inclined to consider the brown-breasted birds as immature, but he is now convinced that the darker individuals represent a 


\section{PUFFINUS CUNEATUS.}

phase of plumage, such as is found in several other species of Petrels. Mr. Anthony undoubtedly proved this to be the case with $P$. cuneatus, as he met with both light and dark-breasted birds on San Benedicto, where, however, the darker form was in the proportion of two to one.

Mr. Anthony says that, in a series of about seventy-five specimens, all manner of intergrades could be found, from those with pure white lower parts, including the under wing-coverts, to those having grey and sooty-brown plumages.

It should be noticed that the colour of the axillaries follows, to a great extent, the phase of plumage. Thus, the grey-breasted birds have greyish-brown axillaries, with a little white near the tip, whereas the white-breasted birds have ashy-coloured axillaries, but with much more white mottling towards the end of the feathers. The whiter the under-surface of the bird, the greater the amount of white on the axillaries.

All but one of the Laysan examples in the Rothschild Collection are of the whitebreasted form, but a grey-breasted bird was found by Palmer on French Frigate Island, along with a white-breasted one. From San Benedicto I have examined seven specimens obtained by Mr. A. W. Anthony. Five of these are sooty-brown below, but the other two are white underneath, one having the sides of the body grey, and the other being slightly washed with ashy-grey. In both phases the axillaries are for the most part grey.

The size, as in other Shearwaters, varies considerably, the following being the measurements of the series examined by me:-

o Wing, 11.1-12.0 inches; culmen, 1.45-1.6; tarsus, $1.8-2.0$; middle toe and claw, 2.1-2.3.

q Wing, 11.3-12.0 inches; culmen, 1.4-1.6; tarsus, 1.8-2.0; middle toe and claw, 2.1-2.25.

Specimens without indication of sex measure :-Wing, 11.2-11.85 inches ; culınen, $1.55-1.65$; tarsus, $1.8-1.95$; middle toe and claw, 2.2-2.4.

It will thus be seen that there is practically no difference in size between the male and female.

The white breast which Salvin considered to be a distinctive character of his $P$. cuneatus is discounted by the discovery of a grey-breasted phase, and in this plumage it is exceedingly difficult to separate the dark form of $P$. cuneatus from $P$. chlororhynchus. The bill of the latter bird is generally smaller, and it has not such a grey throat. The two birds are, however, scarcely distinguishable, and if it should turn out that the dark phase of $P$. cuneatus is not different from $P$. chlororhynchus, we should be confronted with the fact that $P$. chlororhynchus ranges from the Australian seas to the Mascarene Islands, and re-appears in the Japanese seas, extending to the Californian Islands and the Hawaiian Archipelago. In Japan and the other localities to the south, there is a white-breasted phase, which is not found in Australian and Mascarene specimens, which are always dark. I would, however, call attention to the Plate in the 7 th 


\section{MONOGRAPH OF THE PETRELS.}

volume of Gould's " Birds of Australia," where he figures a pale bird of P. chlororhynchus, which appears to answer to the white-breasted phase of $P$. cuneatus. Gould supposed that this was the young of $P$. chlororhynchus, but I have never seen an Australian bird corresponding with his figure. If it should be proved that $P$. chlororhynchus has a light-breasted phase, I do not see how $P$. cuneatus can be upheld as a species.

It is possible that the colour of the bill and feet may distinguish the birds in life, but with regard to this point there is not much definite information.

According to Mr. Seebohm (Ibis, 1891, p. 191,) the late P. A. Holst gave the soft parts of $P$. cuneatus from the Sulphur Islands as follows :- " Bill light grey with a black hook : tarsi and feet pale pink." Holst was a Swede, and wrote very fair English, and I have given above the note on his original label, which Mr. Seebohm has paraphrased.

Professor Schauinsland says that the colour of the bill in Laysan specimens is grey, with a black tip, and the feet bluish-white or whitish-grey, not yellow or red (cf. Rothschild, Avif. Laysan, II., p. 287).

My description and figure are taken from the type in the British Museum. 



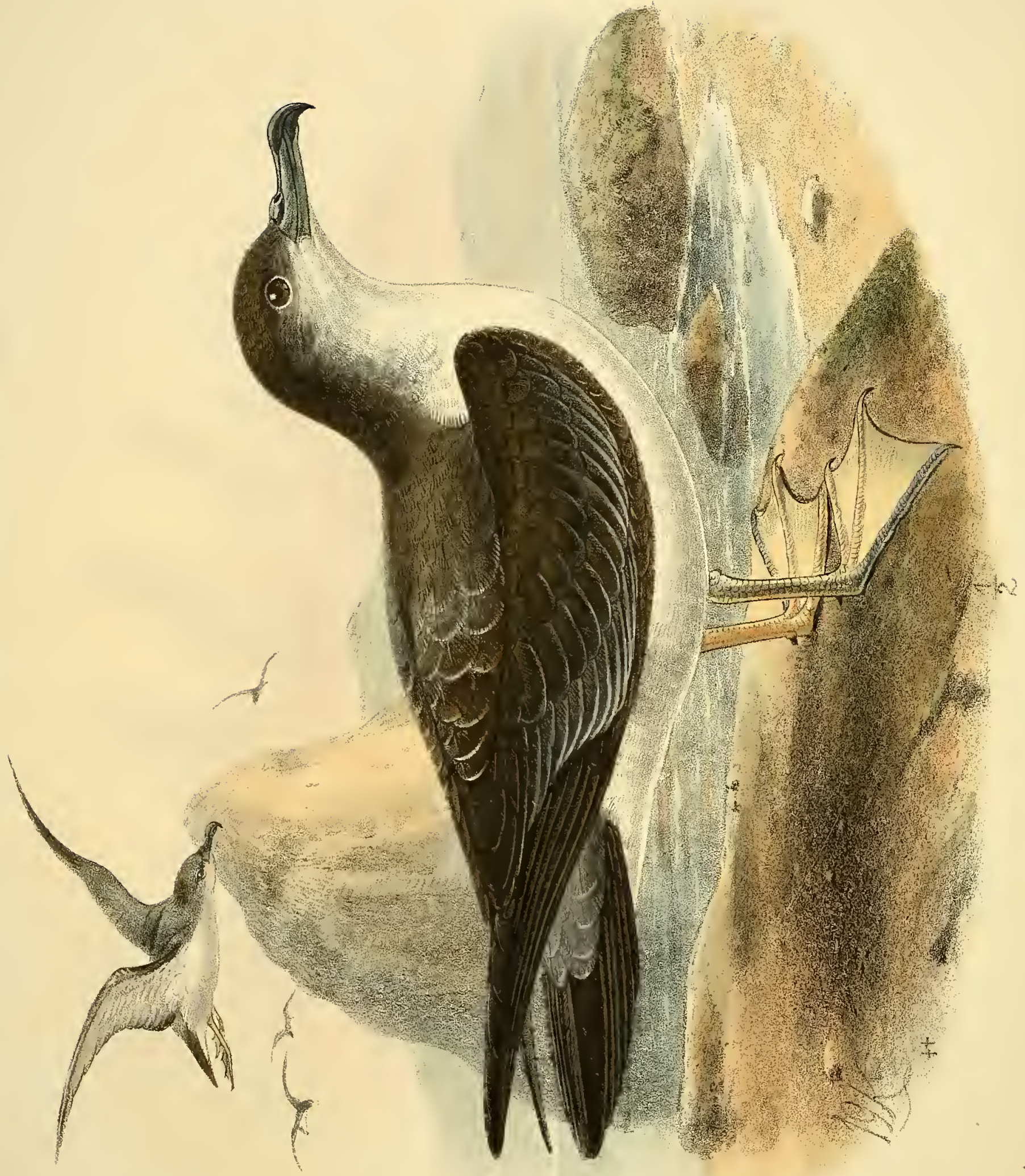




\title{
28. PUFFINUS BULLERI, Salvin.
}

\author{
(BULLER'S SHEARWATER.)
}

(Plate 23.)

Puffinus bulleri, Salvin, Ibis, 1888, p. 354 ; Buller, Birds New Zealand, II., p. 240, Pl. 41, fig. 2 (1888); Salvin, Cat. Birds Brit. Mus., XXV., p. 371 (1896); Anthony, Auk, XV., p. 38 (1898) ; Loomis, Pr. Calif. Acad. Sci. (3) Zool., II., p. 319 (1900) ; Buller, Suppl. Birds New Zealand, I., p. 101 (1905).

Puffinus zealandicus, Sandager, Tr. N. Zeal. Inst., XXII., p. 291 (1890).

Cauda cuneata: gastræo albo: interscapulio, tectricibus alarum majoribus, et secundariis exterioribus, claré cinereis: primariis intus albis.

Puffinus bulleri is a wedge-tailed Shearwater, and is allied to $P$. cuneatus, from which it differs in being ashy-grey on the upper-surface and on the greater wing-coverts, these parts being brown in the latter species. The under wing-coverts, axillaries, and quill-lining are pure white; the under tail-coverts are also for the most part white, the lateral ones more or less ashy-grey externally. The quill-lining is white, instead of dusky as in $P$. cuneatus.

In the "Catalogue of Birds" Salvin stated that the outer half of the inner webs of the primaries is white. This is an evident lapsus calami, as it is the inner half of the quills which is white.

Two specimens only of $P$. bulleri were known to Salvin, when he described the species, one in our own collection of Petrels, and the other in the Rothschild Museum. The former, now in the British Museum, was purchased from Mr. Whitely, of Woolwich. It measures: Wing, 11.1 inches; tarsus, 2.1 ; middle toe and claw, 2.35; culmen, 1.55. In the Rothschild Museum there are now two specimens, one being a co-type of the species, a male from Waikanae: this bird is figured in the present volume, and measures: Wing, 11.5 inches ; tarsus, 1.9 ; middle toe and claw, 2.4 ; culmen, 1.6. A second male example, obtained by Mr. H. Travers on the 5th of May, 1900, measures: Wing, 11.8 inches ; tarsus, 2.0 ; middle toe and 


\section{MONOGRAPH OF THE PETRELS.}

claw, 2.45; culmen, 1.7. It will be noticed that, as in other species of Puffinus, the size of the bill varies considerably.

Sir Walter Buller picked up his first specimen on the beach of the Waikanae River on the 1st of October, 1884. Six examples are now known, viz., the type in the British Museum, two in the Rothschild Museum, one in the Buller Collection (now in the Carnegie Museum at Pittsburg, U.S.A.), one in the Colonial Museum at Wellington, and one recorded by Mr. L. M. Loomis (vide infra).

The specimen in the Colonial Museum was obtained by the late Captain Fairchild at Mokohinu Island in September.

Mr. Anthony states that he noticed a Petrel off the islands of Lower California, which he thought might be Puffinus bulleri, as it agreed very well with the descriptions of that bird. As, however, no specimens were taken, he remarks that it would be unwise to venture an opinion as to its identity ( $A u k, \mathrm{XV} ., \mathrm{p} .38,1898$ ).

In 1900 , however, $P$. bulleri was definitely added to the avifauna of North America by Mr. Leverett M. Loomis, who records, in the "Proceedings" of the California Academy of Science ((3) Zool., II., p. 319, 1900), that he procured a female, or young, specimen of Buller's Shearwater on the 6th of November, about six miles off Point Pinos, California.

Adult. General colour above ashy-grey, including the mantle and scapulars, the longer feathers of the latter being subterminally blackish; wing-coverts also ashygrey, the marginal coverts and those round the edge of the wing blackish, as also the bastard-wing and primary-coverts; primaries also blackish, with the inner web for the most part white, sometimes for two-thirds of the feather ; the secondaries ashygrey, slightly fringed with white, and having the inner web white for two-thirds of its length; the innermost secondaries blackish-brown, like the marginal coverts of the wing ; lower back, rump, and upper tail-coverts ashy-grey, with obsolete white fringes to some of the feathers; tail black; crown of head and nape blackish, the base of the forehead and lores ashy-white with small blackish spots; sides of face and ear-coverts white, the latter ashy-brown above, the former spotted with dusky-brown below the eye ; entire under-surface white, with a patch of ashy-brown on each side of the chest; under tail-coverts white, the longer ones mottled, edged with whitish-brown on the outer edge ; under wing-coverts and axillaries pure white, as also the wing-lining ; "bill blueblack, fading into bluish-grey on the sides of both mandibles; inside of tarsi, which are much flattened, the middle and inner toes, and the inter-digital web fleshy-white; outer aspect of tarsus and the whole of the outer toe brownish-black; iris black" (Buller). Total length 14 inches ; culmen, 1.55 ; wing, 11.1 ; tail, 4.8 ; tarsus, 2.1 ; middle toe and claw, 2.35.

The specimen from Mokohinu Island was sent by Captain Fairchild to the Colonial Museum in spirits, and Buller took the following notes of the colours:-Sides of bill greenish, the culminal ridge and hook brownish-black; feet yellow, the outer side of 


\section{PUFFINUS BULLERI.}

the tarsi and outer toes, and a line along the base of the middle toe on its outer side, blackish. The greenish colour of the bill, he thought, might be a sexual character, as the female he examined did not show it.

Mr. Sandager says that his specimen had the lower part of both mandibles bluish, the remainder black; the outer margin of the tarsus and two outer toes black, the remainder pale with a bluish tinge; inter-digital membrane pale, shaded with black. I have reproduced Mr. Sandager's description of the feet, but it is difficult to understand what he means by the word "pale."

The specimen figured is in the collection of the Hon. Walter Rothschild, and the description is taken from the type in the British Museum. 


\title{
29. PUFFINUS CHLORORHYNCHUS, Lesson.
}

\author{
(WEDGE-TAILED SHEARWATER.)
}

(Plate 24.)

Puffinus chlororhynchus, Less., Traité d'Orn., p. 612 (1831); Milne-Edwards and Grandid., Hist. Nat. Madag., Ois., p. 680, Pls. 297, 298 (1885) ; Buller, Birds N. Zeal., 2nd ed., II., p. 235 (1888); Wiglesw., Abhandl. K. Mus. Dresd., 1890-91, No. 6, p. 80 (1891) ; Salvin, Cat. Birds Brit. Mus., XXV., p. 372 (1896).

Puffinus sphenurus, Gould, Ann. and Mag. Nat. Hist., XIII., p. 365 (1844); id., Birds Austr., VII., Pl. 58 (1848) ; Salvad., Orn. Papuasia, III., p. 464 (1882) ; id., op. cit., Agg., p. 213 (1891).

Le Pétrel chlororhynche, Jacq. et Pucher., Voy. Pole Sud, III., p. 138 (1853).

Nectris gama, Bp., Consp. Av., II., p. 202 (1856).

Thiellus chlororhynchus, Bp., Comptes Rend., XLII., p. 769 (1856) ; id., Consp. Av., II., p. 201 (1856); Coues, Pr. Acad. Philad., 1864, pp. 123, 142.

Thiellus sphenurus, Bp., Comptes Rend., XLII., p. 769 (1856) ; id., Consp. Av., II., p. 201 (1856) ; Coues, Pr. Acad. Philad., 1864, pp. 122, 142 ; Gould, Handb. Birds Austr., II., p. 466 (1865).

Puffinus obscurus (nec Gm.), Elwes, Ibis, 1859, p. 397.

Majaqueus sphenurus, Rosenb., Nat. Tijdschr. Nederl. Ind., XXV., p. 256 (1863).

Procellaria sphenura, Schlegel, Mus. Pays-Bas, VI., Procell., p. 25 (1863).

Procellaria chlororhyncha, Schlegel, t.c., p. 25 (1863).

Puffinus cinereus (nec Gm.), Layard, Ibis, 1863, p. 247.

Puffinus sp., Legge, Str. F., III., p. 374 (1875).

Puffinus carneipes (nec Gould), Cheeseman, Tr. N. Zeal. Inst., XXIII., p. 226 (1891 ; teste Hutton).

Mutton-bird, of Australian Naturalists.

Cauda longa, cuneata: undique fuliginoso-brunneus.

AutHoणGH resembling the foregoing species in its wedge-shaped tail, $P$. chlororhynchus 

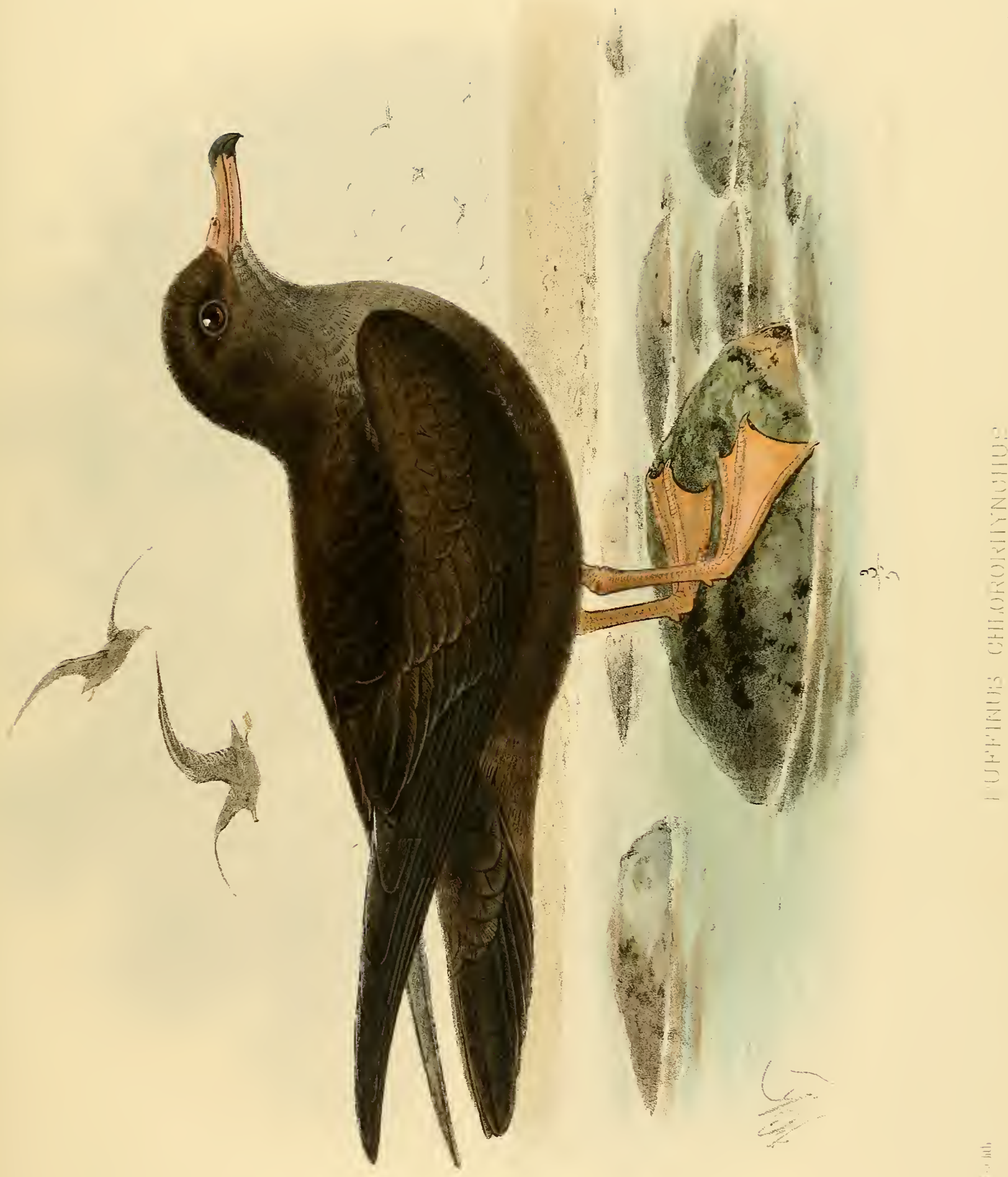



\section{PUFFINUS CHLORORHYNCHUS.}

is distinguished by its uniform brown colour, the dark brown breast being a prominent specific character.

The range of $P$. chlororhynchus extends from Australia and the adjacent islands to Mauritius and other Mascarene islands ; and, as far as I can judge, from a study of the large series in the British Museum and in the Rothschild Collection, there is but one species throughout this widely-extended area, though some ornithologists have considered that the Wedge-tailed Shearwater of the Mascarene Islands is specifically distinct from its representative in Australia. Schlegel, for instance (Mus. Pays-Bas, VI., Procell., p. 25), separates the Australian bird, which he calls $P$. sphenurus, Gould, from the bird of Réunion, which he calls $P$. chlororhynchus, Lesson. The latter, he says, is of a stouter build, and has an orange-coloured bill, black anteriorly, whereas in $P$. sphenurus the bill is brown.

It is possible that the bird from the Mascarene Islands may yet prove distinct from the Australian form, to which the name of sphenurus has been generally applied, but I find no difference of plumage in specimens from these distant localities, and specific characters will have to be sought in the colour of the bill and feet. It should be observed that no naturalist has, as yet, recorded any freshly-killed specimen as having a green bill, and it is somewhat curious that Lesson should bestow the name of chlororhynchus on a bird which, by his own account, had a yellow bill, for his diagnosis is as follows:- "Bill yellowish at base, black at tip; tarsi yellow; plumage sootybrown; wings and tail dull black." This author gives no locality for his species, but Pucheran, in his essay on Lesson's types (Rev. Zool., 1850, p. 633), says that the specimen described by Lesson was in the Paris Museum, and was obtained by Quoy and Gaimard in December, 1820, in the "Baie des Chiens Marins." From the report of the voyage of the "Uranie" and "Physicienne" (p. 150) it seems that the bay above alluded to is Shark's Bay in Western Australia, and Peron's Peninsula is mentioned as being in the vicinity.

It is, therefore, evident that the name of chlororhynchus cannot be applied, as has hitherto been the custom, to the Mauritius bird, but belongs to the Australian species; and if this should prove to be distinct, Gould's name of $P$. sphenurus would be superseded by that of $P$. chlororhynchus, founded on an Australian specimen.

Pucheran, who made the above identification, did not arrive at this conclusion, but considered that Lesson's species was not identical with $P$. sphenurus, Gould, $P$. brevicaudus, Gould, or P. carneipes, Gould. According to Pucheran, the type measures 34 centimetres ( $=13.4$ inches) from the tip of the bill to the end of the tail, the wings extending beyond the latter. The yellow colour of the bill and feet is confirmed by him, and he further states that the type of $P$. chlororhynchus is not identical with $P$. sphenurus, but, from its short tail, approaches $P$. brevicaudus and $P$. carneipes, being distinguished from both of these by its more slender bill.

Dr. Menegaux, the successor of the late Dr. Oustalet at the Paris Museum, has kindly 


\section{MONOGRAPH OF THE PETRELS.}

sent me a full description and measurements of the type-specimens of $P$. chlororhynchus. The length of the centre tail-feather is $118 \mathrm{~mm} .(=4.7$ inches), and of the outer feathers $80 \mathrm{~mm}$. ( $=3.2$ inches).

No specimen of $P$. tenuirostris or $P$. carneipes examined by me has a tail exceeding 4.5 inches in length, and consequently the type of $P$. chlororhynchus seems to be identical with the bird which was described by Gould as $P$. sphenurus. Without comparing the actual specimen, it is, of course, somewhat difficult for me to give a decided opinion, but the details kindly supplied by Dr. Menegaux seem to leave little doubt on the subject.

I can find no specific characters in the dimensions of specimens from eastern and western localities, as is proved by the series in the British Museum and the Rothschild Collection.

\begin{tabular}{ccccccc} 
Wing. & & CuImen. & & Tarsus. & & \multicolumn{1}{c}{$\begin{array}{c}\text { Middlo toe } \\
\text { and claw. }\end{array}$} \\
Mauritius, etc. $10.2-11.5$ & $\ldots$ & $1.4-1.5$ & $\ldots$ & $1.7-1.9$ & $\ldots$ & $2.25-2.5$ \\
Australia, etc. $11.0-12.5$ & $\ldots$ & $1.35-1.7$ & $\ldots$ & $1.7-2.1$ & $\ldots$ & $2.1-2.5$
\end{tabular}

It will be observed that, although the Australian birds are slightly larger, there is a gradation in size in the Mascarene examples, which approaches that of the Australian form; but those from the Kermadec Islands, as already pointed out by the late Captain Hutton, are certainly larger than the general run of Australian birds. He gives the following measurements :- "Wing, 12.75 inches ; tail, 6.5 ; culmen, 1.65, tarsus, 1.9 ; middle toe and claw, 2.2." I also find that Kermadec specimens in the British Museum and in the Rothschild Collection are slightly larger than Australian examples as regards the length of wing. They measure :Wing, 12.1-12.5 inches; culmen, 1.55-1.7; tarsus, 1.9-2.1; middle toe and claw, 2.3-2.5. There is nothing here which would suggest a specific distinction for the Kermadec bird, though the plumage is somewhat darker than in those from Australia.

The evidence as to the difference in the colour of the bill and feet in the eastern and western birds cannot yet be considered satisfactory. Gould gives them as follows:- "Bill reddish fleshy-brown, darker on the culmen and tip; legs and feet yellowish flesh-colour." These do not agree with the Plate in his folio edition of the "Birds of Australia," where the bill is rendered of a blackish colour throughout. Buller, in his "Birds of New Zealand," says that the bill is greyish-black, the legs and feet yellowish-brown. Salvin (Cat. Birds Brit. Mus., XXV., p. 372) gives the colours as follows :- "Bill flesh-colour, the tip dark; tarsi and toes flesh-colour, the outer toe darker, especially on the joints of the phalanges." Mr. Robert Hall (Ibis, 1902, p. 104) dissents from Salvin's statement, and says that a specimen obtained by him on Houtman's Abrolhos, had the bill "slate-colour, with the tip or nail black, and the feet fleshy-white." In a bird obtained on the Kermadecs by the Earl of Ranfurly the colour of the feet is given as dull yellowish. 


\section{PUFFINUS CHLORORHYNCHUS.}

Very few details of the colour of the soft parts in Mascarene birds are to hand. Grandidier, in the "Histoire Naturelle de Madagascar," says that the bill is greenish and the feet yellowish. This is the only instance in which I have found the colour of the bill to be in accord with Lesson's name of chlororhynchus, and I doubt if this note can have been taken from a recently killed bird. Dr. Coppinger gives the colour of the bill as dark horn-colour in a specimen he obtained on Bird Island, Seychelles, and the feet as fleshy-grey. The birds procured by the late Sir Edward Newton had yellowishwhite legs and feet (Ibis, 1861, p. 181). Specimens from the Seychelles, in the Rothschild Museum, collected by M. Thibault, bear on their labels a note to the effect that the bill and feet are "rose." This is a remarkable observation, being entirely at variance with the other records, but it must be mentioned that a specimen in the British Museum, received many years ago from the Maison Verreaux, as from the island of Réunion, had the bill and feet painted of a rosy tint. It is evident, therefore, that we have not yet arrived at a solution of the question as to whether the Réunion and Mauritius birds are the same as the Australian, but the evidence at our disposal seems to hint that they may, after all, not belong to the same species.

$P$. chlororhynchus inhabits the islands and coasts of Australia from Queensland to New South Wales and Tasmania, and thence to Western Australia.

Specimens procured on Raine's Islet, off Northern Queensland, by the late John Macgillivray and Dr. J. Beete Jukes, are in the British Museum, as well as one from Bird Islet, doubtless also collected by Macgillivray, and formerly in the Gould Collection. The species breeds on Norfolk, Philip, and Nepean Islands (Crowfoot, Ibis, 1885, p. 268), and Mr. Robert Etheridge says that it is found together with $P$. tenuirostris on Lord Howe Island, breeding on "Mutton-bird" and "Goat" Islands, and also on the Admiralty Islets (Rep. Lord Howe Isl., p. 14).

The Shearwater which breeds in such abundance in the islands of Bass's Straits appears to be $P$. tenuirostris, and not $P$. chlororhynchus, and the latter is not mentioned by Gould or any recent writers as nesting there. Mr. D. Le Souëf, however, states that it formerly bred near Sorrento, in the vicinity of Melbourne.

He visited the locality in 1901, and found a deserted rookery on the Cape Schrank side. The Crown keeper stated that no Shearwaters had nested on the mainland for the past ten years, as the foxes killed them all, and he had found scores lying about on the old rookery with their heads bitten off. On the Portsea side Mr. Le Souëf found no evidence of the existence of these birds.

In a joint paper by Mr. A. G. Campbell and Mr. A. H. E. Mattingley on the Petrels of Mud Island, opposite the entrance to Port Phillip Bay (Emu, VI., p. 185), there is an excellent account of the nesting of Pelagodroma marina, in which "Mutton-birds" are also mentioned. The writers were informed by Mr. Joseph Gabriel that many years ago the White-faced Storm-Petrel ( $P$. marina), and also the "Mutton-birds" did 


\section{MONOGRAPH OF THE PETRELS.}

not nest, but were found dying in thousands along the shore. This statement, however, probably refers to $P$. tenuirostris, and not to $P$. chlororhynchus.

Gould does not appear to have met with the species himself, but relates that Gilbert found it on Houtman's Abrolhos, off the coast of Western Australia. It was nowhere so abundant as on West Wallaby Island, which was one of its chief breeding places (Handb. Birds Austr., II., p. 466).

Mr. Hall (Vict. Nat., XVIII., p. 168) found the burrows of P. chlororhynchus prepared for nesting in November on a small island at the entrance of Denmark River, about forty miles from King George's Sound. Mr. Campbell (Emu, IT., p. 36, 1902) suggests that the species was $P$. carneipes, which is known to breed on Breaksea Island, at the entrance of the Sound, as $P$. chlororhynchus has not been found breeding on the western coast south of Rottnest Island, off Fremantle, where Mr. Lawson records its nesting (Emu, IV., p. 135).

Sir Walter Buller has entered the species as a New Zealand bird on the strength of two specimens recorded by Salvin as from that country. These examples were formerly in our own collection, and were purchased of Whitely; the locality may be erroneous, as the species has not since been found in New Zealand.

In the Kermadec Islands, Mr. Cheeseman states that this Shearwater arrives in October, often in very large numbers; it digs out burrows, frequently several feet in length, on the edges of cliffs, or on margins of inland terraces.

P. chlororhynchus is mentioned by Count Salvadori (Orn. Papuasia, III., p. 464) as having been procured by D'Albertis off the Kataw River in Southern New Guinea. Wiglesworth, in his work on the Avifauna of the Pacific (Abhandl. K. Mus. Dresden, VI., p. 80), records it as probably from the Caroline Islands (obtained by Kubary), the Phonix Islands, and the Society Islands.

In the Phœnix Group it was met with by Gräffe on McKean's Island (Hartl. and Finsch, Faun. Central-Polyn., p. 245, 1867), and specimens obtained on Eimeo, in the Society Group, by Mr. Green, are in the British Museum (Salvin, Cat. Birds Brit. Mus., XXV., p. 372), and in the Tristram Collection (Tristr., Cat. Coll., p. 5).

This bird also visits the Indian Ocean, though the records are as yet few. Jerdon says that he saw a Petrel off the coast of Madras in rough weather; it was of a dull sooty-brown colour, paler beneath. It may well have been P. chlororhynchus (Birds Ind., II., p. 826). Mr. E. W. Oates considers that the species is likely to occur along the Burmese coasts. The only example, however, actually obtained in Indian waters is recorded by Colonel Vincent Legge as having been procured by Mr. McVicar on the 15th of May, at Bolgodde Lake, a large sheet of water discharging into the sea fifteen miles south of Colombo (Birds of Ceylon, p. 1,054).

In the British Museum are several specimens from Mauritius, and both Sir Edward Newton and Mr. E. L. Layard found P. chlororhynchus nesting on Round Island. From the Seychelles I have also seen examples in the National Collection, from Praslin 


\section{PUFFINUS CHLORORHYNCHUS.}

and Bird Islands, and the Hon. Walter Rothschild has adults and nestlings, obtained by M. Thibault on Cousine Island, proving that the species breeds there. Specimens from Réunion and Rodriguez (H. H. Slater) are also in the British Museum.

The habits of $P$. chlororhynchus are similar to those of other members of the genus Puffinus, but I am unable to decide, in every case, to which species many of the recent notes published in Australian journals refer, as the ranges of $P$. chlororhynchus and $P$. tenuirostris are, in many parts of Australia, coterminous. They are simply spoken of as "Mutton-birds," a name applied equally to both the brown Shearwaters.

On Lord Howe Island, Mr. Robert Etheridge states that the birds begin to arrive at the latter end of August, and nest in burrows usually hidden under a tussock of grass, or occasionally in a mere depression of the surface. The smell from this Shearwater's abode is, like that of other species of Puffinus, most obnoxious. Macgillivray, Newton, and others, say that these birds not only bite severely, if incautiously handled, but disgorge a quantity of offensive oily matter, the odour of which pervades the whole island.

On approaching a colony one bird will give the alarm, and a chorus of the most extraordinary sounds proceeds from underground, more resembling the squalling of cats than any other noise. At night, the cries are renewed, till it seems as if the whole island were in distress.

Mr. Hall says that the young birds are very pugnacious, and if two of them were placed in the same box overnight, one would be found dead in the morning. A similar statement of their ferocity is made by Sir Walter Buller, and Mr. Hall states that the same is true of other Petrels (Ibis, 1902, p. 204).

Adult. General colour above sooty-brown, the feathers with more or less distinct edges of lighter brown, these edges more evident on the scapulars and inner secondaries, where the feathers are blackish-brown towards the ends; wing-coverts like the back; quills blackish, the secondaries shaded with ashy-grey on the outer webs; tail-feathers black, somewhat lighter on the inner webs of some of the outer ones; crown of head like the back, but with a slight shade of ashy on the lores, sides of face, and cheeks ; throat more decidedly ashy-grey, becoming duller grey on the fore-neck; the remainder of the under-surface from the fore-neck downwards dull ashy-brown, with faint indications of rusty edges to the feathers; under tail-coverts also ashy-brown; axillaries and under wing-coverts like the breast; quills dusky below, the lower greater-coverts and the inner webs of the quills rather more ashy. Total length about 17.5 inches ; culmen, 1.65 ; wing, 11.6 ; tail, 5.3 ; tarsus, 1.9 ; middle toe and claw, 2.45.

The description is taken from an adult bird in our own collection, presented to us by Dr. Crowfoot, from Norfolk Island. The specimen figured is also in our collection, from Praslin in the Seychelles Archipelago. 


\section{PUFFINUS GRAVIS (O'Reilly).}

\section{(GREAT SHEARWATER.)}

(Plate 25.)

Shearwater Petrel, var. A., Lath., Gen. Syn. Birds, III., pt. 2, p. 407 (1785).

Procellaria gravis, O'Reilly, Voy. Greenland, p. 140, Pl. 12, Fig. 1 (1818).

Procellaria major, Faber, Prodr. Isl. Orn., p. 56 (1822) ; Schlegel, Mus. Pays-Bas, VI., Procell., p. 27 (1863).

White-faced Petrel, Lath., Gen. Hist. Birds, X., p. 185 (1824).

Puffinus cinereus (nec Gm.), Audub., Birds Amer., Pl. 283 ; id., Orn. Biogr., III., p. 555 (1835).

Nectris cinerea, pt. Keys. and Blas., Wirb. Eur., pp. xciv., 239 (1840).

Puffinus major, Temm., Man. d'Orn., IV., p. 507 (1840) ; Coues, Pr. Acad. Philad., 1864, pp. 132, 144; Saunders, Man. Brit. Birds, p. 715 (1889).

Greater Shearwater, Yarrell, Brit. Birds, III., p. 502 (1843).

Puffinus gravis, Salvin, Cat. Birds Brit. Mus., XXV., p. 373 (1896); Saunders, Man. Brit. Birds, 2nd ed., p. 737 (1899).

Major : cauda rotundata: subtus albus, abdomine brunneo notato: axillaribus albis, brunneo terminaliter notatis.

The Great Shearwater is the largest Petrel found in British waters, the only species with which it could be confounded being the Mediterranean $P$. kuhli. It is brown on the back, and has a dark brown, instead of a grey, head; the sides of the face and neck are not freckled, but uniform white, extending backwards and almost meeting at the back of the neck. Another distinctive character of $P$. gravis is the brown mottling on the middle of the abdomen, which is due to the brown tips of the feathers; the axillaries have also brown spots near the ends. Salvin has not insisted on these characters, but they seem most important for the recognition of the species.

$P$. gravis occurs off the coasts of Great Britain, more especially on the southwestern side; and Mr. Eagle Clarke, who spent some time on the Eddystone Rock, studying the migration of birds, saw large numbers, when the shoals of Pilchards were in the vicinity (Ibis, 1902, p. 262). This Shearwater is recorded from the Orkneys 

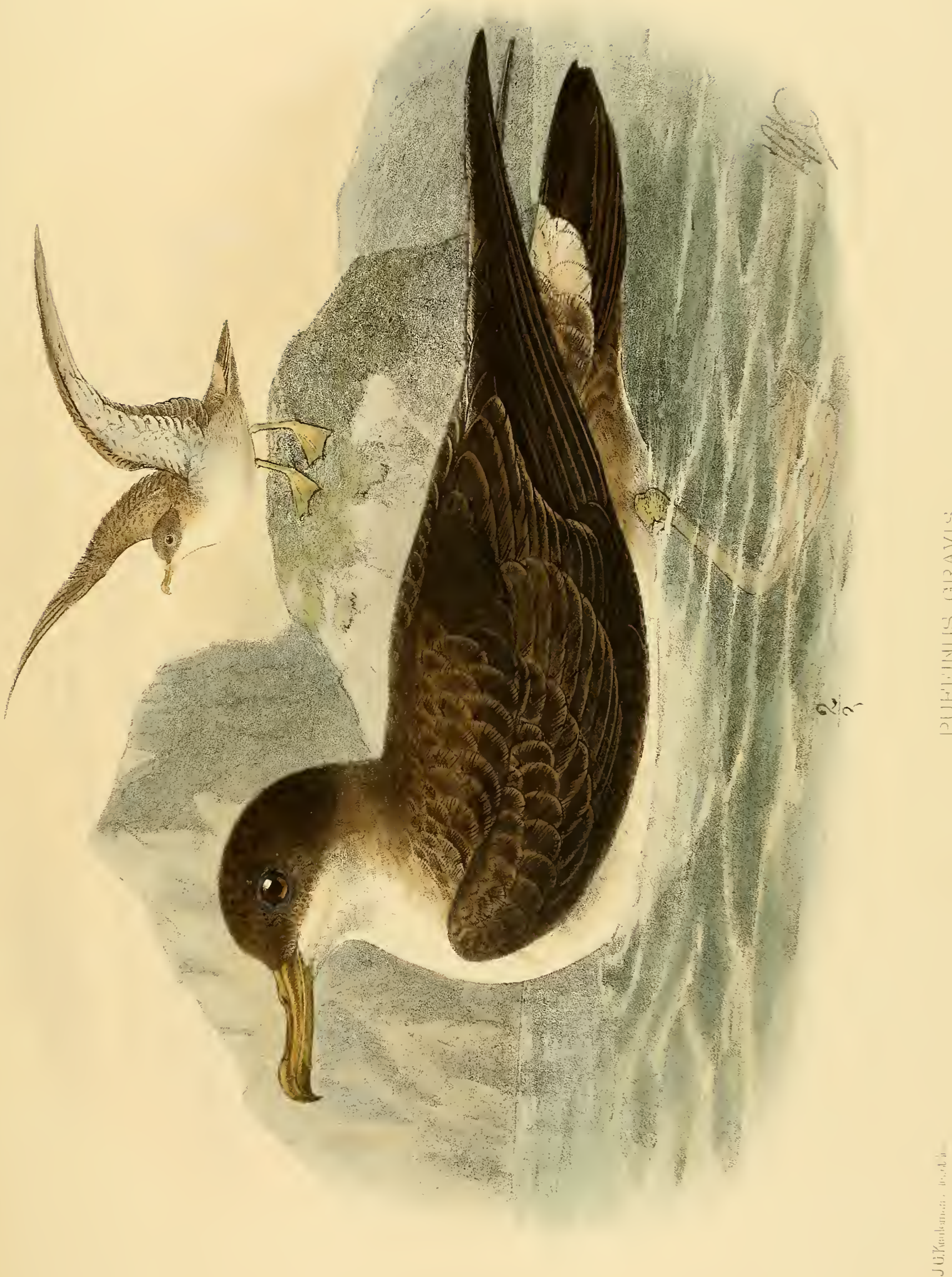



\section{PUFFINUS GRAVIS.}

and Shetlands, and, by the late Professor Newton, as abundant amongst the Western Hebrides. Messrs. Harvie-Brown and Barrington observed it in numbers off the Rockall Banks in June, but it was not breeding there (Tr. R. Irish Acad., XXXI., pt. 3, p. 66). June is the earliest record of its appearance in northern waters, but Mr. Howard Saunders mentions that many individuals have been seen on the east coast of England in September, and on one occasion as late as the 10th of November (Man. Brit. Birds, 2nd ed., p. 737), and he also notes its occurrence on the coasts of Ireland and Normandy. It was observed off Ushant in September, and also off the Casquets, by Mr. Eagle Clarke, in company with Manx Shearwaters (Ibis, 1899, p. 270). In the vicinity of Heligoland, flocks have been seen at rare intervals, and the species ranges to the Norwegian coast, as well as to the Faroes. Faber described the species as Procellaria major from Iceland, where, according to Mr. H. J. Pearson, it is known as the "Stóra Skrofa" (Ibis, 1895, p. 249).

The Great Shearwater is often seen in the North Atlantic Ocean, in autumn and winter, but Seebohm considered it to be much more local than the Fulmar, or Wilson's Storm-Petrel; it was generally seen in pairs, though occasionally in small flocks.

Dr. Walker, of the "Fox," states that he saw P. gravis off Cape Farewell, but there is no conclusive evidence that it nests in Greenland (Ibis, 1860, p. 165). Although Dr. Brewer says that he possesses eggs taken in Greenland, and quotes Dr. Bryant, who states that a Puffinus is very numerous at Belle Isle in July, when the birds might reasonably be thought to be feeding their young, the inhabitants told him that they had never found an egg, nor knew of a Shearwater breeding there. Dr. Brewer, however, thinks that Mr. Dresser was mistaken in disavowing the Greenland eggs, taken by the Moravian missionaries.

Giraud says that the Great Shearwater is of rare occurrence off Long Island, but is more frequent on the coasts of Newfoundland and Nova Scotia, and it has been recorded by Mr. Hurdis from Bermuda.

To the southward, Mr. Nicoll saw these birds, in pairs, off Tristan d'Acunha, and between that island and the Cape of Good Hope, when on Lord Crawford's yacht, the "Valhalla," in 1906. In the Rothschild Collection there is a specimen from Inaccessible Island, captured on the 23rd January, 1904. At this time of year the Great Shearwater is absent from the British seas. A specimen, now in the British Museum, was procured by Sir Andrew Smith in South Africa, and the Leyden Museum possesses two examples, one from the Cape seas, and another from the Gold Coast, the latter obtained by Governor Pel (Schlegel, Mus. Pays-Bas, VI., Procell., p. 27). The species is said to occur on the Falkland Islands, and Dr. Brewer mentions an example in the U. S. National Museum as obtained by Titian Peale on Tierra del Fuego. 


\section{MONOGRAPH OF THE PETRELS.}

That the breeding-place of $P$. gravis must be sought for in southern latitudes can scarcely be doubted, and that it likewise nests there during our winter, and returns north during our summer, is also most probable, but the evidence is not yet entirely satisfactory. The fact of the birds being seen in pairs by Mr. Nicoll, does not, under the circumstances, count for much, as this habit has also been noted in northern seas. From our present knowledge, however, I am inclined to agree with Mr. Howard Saunders and Mr. Dresser, that we have no trustworthy evidence of the nesting of the Great Shearwater in northern latitudes, and that the nestlings in the British Museum from the Orkneys, labelled $P$. cinereus (i.e., $P$. gravis), are not referable to that species, but to $P$. anglorum (Gray, Cat. Brit. Birds, p. 223, 1863).

Many naturalists have observed this species on the Atlantic, and all agree that it is a bird of powerful flight. When fishing, it is said to strike the water with great violence, and this peculiarity has been noticed by Captain J. W. Collings, and also by Mr. R. Warren and Mr. Eagle Clarke. Professor Newton, however, says that, though he observed this Shearwater in large numbers, while cruising among the Western Hebrides in 1894 and 1895, the birds were usually sitting on the water in pairs, and none were seen to dive.

Audubon relates that two birds which had been caught with hooks walked about like Ducks, and, when approached, would open their bills and emit through their nostrils an oily substance. When held in the hand they continued to do this, at the same time scratching with their sharp claws and bills. They refused all food, and, being unpleasant pets, were set at liberty, when, instead of flying away directly, they plunged into the water, splashing and diving about before they took to their wings. In the stomachs of those he examined, Audubon found portions of fish, crabs, seaweed, and oily substances.

Adult. General colour above sooty-brown, all the feathers rather broadly margined with paler and more ashy-brown, some of these margins whiter on the scapulars and inner secondaries; upper tail-coverts like the back, the longer ones white or tipped with white, forming a band; quills and tail black; crown of head and hind-neck uniform sooty-brown, the latter encroached upon by the white sides of the neck, with a few faint mottlings of brown where the white meets the brown of the hind-neck ; lores, sides of face, and ear-coverts, sooty-brown, with a slight mottling of hoary-white in front of the eye and below the latter; cheeks white, well-defined in a line from the dark ear-coverts and lores; entire under-surface of body white, the centre of the lower breast and abdomen mottled with pale ashy-brown tips to the feathers; sides of the fore-neck ashy-brown, most of the feathers broadly edged with white; on the sides of the chest a few brown bars, corresponding to the colour of the axillaries, which are white, with conspicuous sub-terminal spots of ashy-brown; under wing-coverts white, with distinct longitudinal centres of sooty-brown, the small coverts round the bend of the wing mostly of the latter colour ; quills dusky-brown below, with 


\section{PUFFINUS GRAVIS.}

the quill-lining distinctly hoary-grey on the inner web; a conspicuous patch of sootybrown feathers over the thigh; under tail-coverts sooty-brown, the longer ones tipped with white, and some of them having a longitudinal white centre; "bill yellowish-green; edges of eyelids dark grey; iris brown; feet light greenish-grey, webs and claws yellowish flesh-colour" (Audubon). Total length about 17 inches; culmen, 1.8; wing, 12.8 ; tail, 4.5 ; tarsus, 2.1 ; middle toe and claw, 2.55.

The description has been taken from a specimen shot off Plymouth, in the Howard Saunders Collection, now in the British Museum. It was given by Gould to Frederic Bond, by whom it was presented to Howard Saunders. 


\section{PUFFINUS KUHLI (Boie). \\ (MEDITERRANEAN SHEARWATER.)}

(Plate 26.)

Le Puffin cendré, Brisson, Orn., VI., p. 134 (1760).

Le Puffin, Daubent., Pl. Enl., X., Pl. 962.

Procellaria puffinus (nec Linn.), Temm., Man. d'Orn., II., p. 805 (1820); Kuhl, Beitr., p. 146 (1820).

Cinereous Puffin, Nutt., Man. Water Birds, p. 334 (1834).

Procellaria kuhli, Boie, Isis, 1835, p. 257.

Puffinus cinereus (nec Gm.), Gould, Birds Eur., Pl. 445 (1847), et auct. recent.

Nectris cinerea (nec Gm.), Keys. and Blas., Wirb. Eur., pp. xciv., 239 (1840, pt.).

Procellaria flavirostris, Gould, Ann. and Mag. Nat. Hist., XIII., p. 365 (1844).

Puffinus kuhli, Bp., Consp. Av., II., p. 202 (1856) ; Coues, Pr. Acad. Philad., 1864, pp. 128, 143 ; Sharpe, Phil. Trans., Vol. CLXVIII., p. 122 (1879) ; Baird,

Brewer, and Ridgway, Water-Birds N. Amer., II., p. 377 (1884); Salvin,

Cat. Birds Brit. Mus., XXV., p. 375 (1896); Ogilvie-Grant, Ibis, 1896, p. 47, 1902, p. 169.

Adamastor flavirostris, Bp., Consp. Av., II., p. 188 (1856).

Nectris macrorhyncha, Heugl., Syst. Uebers., p. 68 (1856).

Estrelata flavirostris, Bp., Comptes Rend., XLII., p. 768 (1856).

Procellaria cinerea (nec Gm.), Schl., Mus. Pays-Bas, VI., Procell., p. 24 (1863).

Puffinus major (nec Faber), Godman, Ibis, 1866, pp. 103, 107 ; id., Nat. Hist. Azores, pp. 39, 42 (1870) ; Loche, Expl. Sci. Algér., Ois., II., p. 173 (1867).

Puffinus borealis, Cory, Bull. Nutt. Orn. Club, VI., p. 84 (1881); Baird, Brewer and Ridgway, Water-Birds N. Amer., II., p. 379 (1884) ; Ridgway, Man. N. Amer. Birds, p. 59 (1887).

Puffinus kuhlii kuhlii, Hartert, Nov. Zool., XII., p. 97 (1905); Butteríeld, Bull. B. O. C., XVI., p. 97 (1905).

Puffinus kuhlii flavirostris, Hartert, t.c., p. 97 (1905).

Major : cauda breviore: corpore subtus albo, minime brunneo notato: ala longiore. 

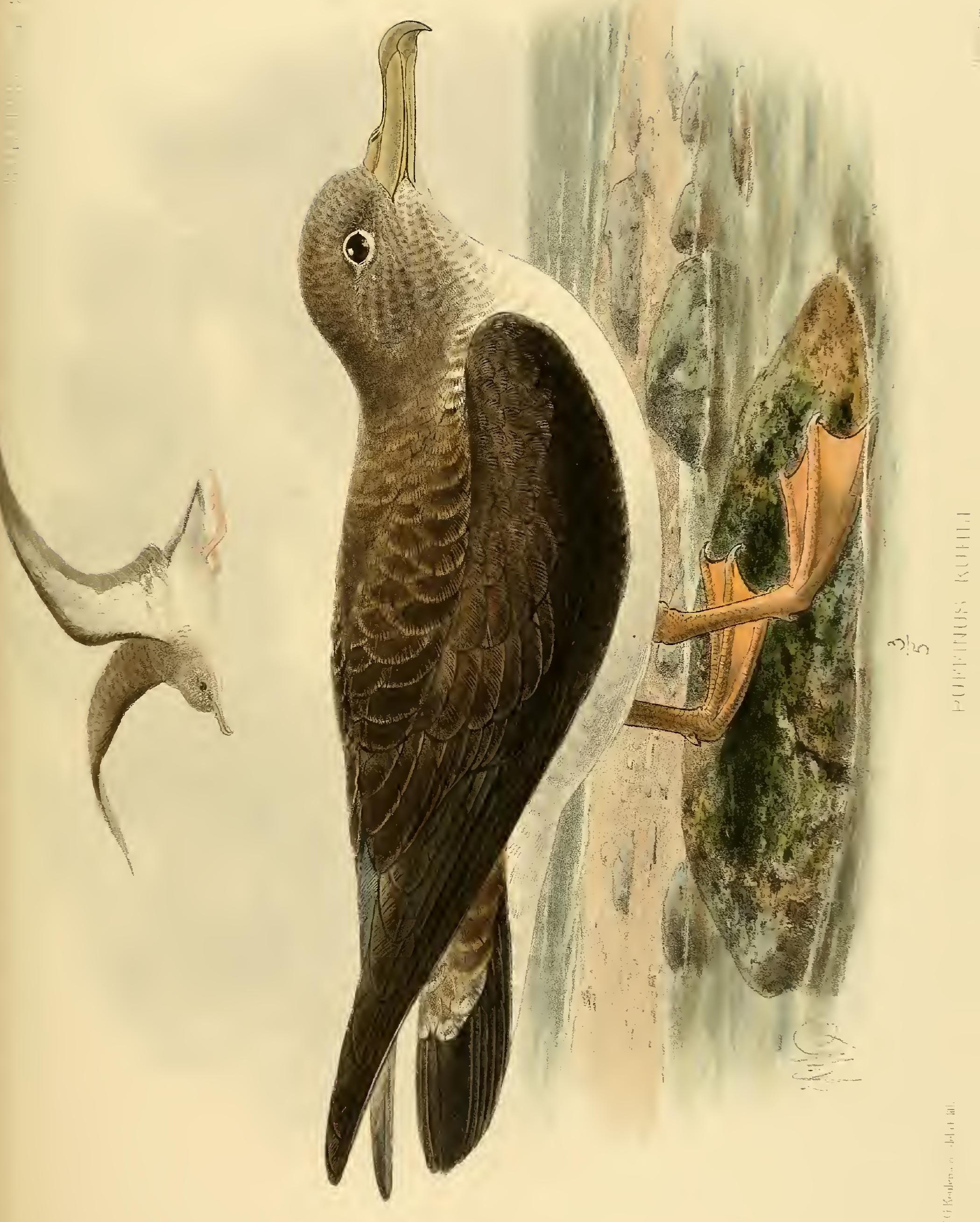


\section{PUFFINUS KUHLI.}

THE Mediterranean Shearwater is one of the largest species (wing, 12.5-14.5 inches) of the genus, having the rounded tail of $P$. gravis, and approaching it in size and general appearance. It is, however, easily distinguished by its pure white under-surface and axillaries, having none of the large brown spots so conspicuous on these parts in $P$. gravis, with which $P$. kuhli has more than once been confounded. The uppersurface is slightly mottled with pale edges to the feathers, and the upper tail-coverts are margined with white; the head is also slightly darker than the back, but not so pronounced as in $P$. gravis.

In the true $P$. linhli of the Mediterranean the quill-lining is generally white. In the birds of the Azores and Madeira it is dusky, and thus, at first sight, the two forms appear to be specifically distinct. Dr. Hartert puts the case very fairly for the identification of the two sub-species (Nov. Zool., XII., p. 97), and sums up the characters as follows:-The bill in the Mediterranean bird, $P$. kuhli, is generally thicker, higher and longer; but males must be compared with males, and females with females. The crown and sides of the head are generally darker, more slaty, paler and more cinereous in $P$. kuhli than in the Atlantic form, which he calls $P$. flavirostris, in which the outer primaries are uniformly dark below, with no white beyond the under wing-coverts, whereas in P. kuhli the white extends beyond the under wing-coverts, sometimes even beyond the middle of the feathers. Dr. Hartert says that there is very rarely any deviation in this characteristic, and it is this feature which raises the question of specific identity. I find that there is usually a distinction between the light-winged bird of the Mediterranean and the dark-winged form from the Azores and Canaries, but no hard-and-fast line can be drawn. Having examined the specimens in the Rothschild Museum and the series in the British Museum, on which Salvin depended, I am driven to the conclusion that a perfect gradation exists, and I follow Salvin in uniting the two races.

The Mediterranean Shearwater is rightly named, for it is abundant in that sea from the Straits of Gibraltar to the shores of Palestine, extending to the Adriatic and to the Sea of Marmora, and nesting in the Balearic Islands, Corsica, Sardinia, and other suitable places during the months of May and June. Count Arrigoni degli Oddi says that it is not rare in the Gulf of Venice (Atl. Orn., p. 525). Mr. C. A. Wright found it breeding in the Maltese Islands in June and July, taking its departure in October (Ibis, 1874, p. 240).

Beyond the limits of the Mediterranean, $P$. kuhli extends to the Portuguese coast, where the differences between it and $P$. major are recognised by the fishermen (Tait, Ibis, 1887, p. 398). I have not seen specimens from Portugal, but they will probably be found to belong to the dark-winged form ( $P$. flavirostris), which occurs in the Atlantic. Mr. Nicoll, during the voyage of the "Valhalla," noticed these Shearwaters between Lisbon and Madeira (Ibis, 1904, p. 33). The type-specimens of $P$. Alavirostris are said by Gould to have been procured by Sir George Grey, on one of his voyages to Australia, in the Cape seas in Lat. $36^{\circ} 39^{\prime} \mathrm{S}$., Long. $10^{\circ} 3^{\prime} \mathrm{E}$. 


\section{MONOGRAPH OF THE PETRELS.}

The following measurements are given by Gould:- “Total length, 19 inches; bill, $2 \frac{3}{4}$; wing, 15.0 ; tail, $6 \frac{1}{2}$; tarsi, $2 \frac{1}{8}$; middle toe and claw, $3 \frac{1}{8}$." The occurrence of the species in the seas of South Africa seems to have been overlooked by Dr. Bowdler Sharpe, in his edition of Layard's "Birds of South Africa"; but Mr. W. L. Sclater (Faun. S. Afr., Birds, IV., p. 469) points out that a specimen of this Shearwater was obtained by the Novara Expedition off the Cape of Good Hope in Lat. $36^{\circ}$ S., Long. $5^{\circ} \mathrm{E}$, and another in Lat. $35^{\circ} 8^{\prime}$ S., Long. $7^{\circ} \mathrm{E}$. It likewise occurs in Kerguelen Island, having been procured by the Antarctic Expedition (Sharpe, l.c.), but Mr. Robert Hall did not meet with it there. Mr. M. J. Nicoll observed the species between St. Paul's Rocks and Bahia (Ibis, 1906, p. 667).

$P$. kuhli has been seen in great numbers off the island of Tenerife (Savile Reid, Ibis, 1888, p. 80), and Mr. Meade-Waldo states that it is resident in the Canaries, and that he has seen these Shearwaters in flocks of many thousands between Gran Canaria and Fuerteventura (Ibis, 1893, p. 207). In the spring of 1890 Mr. Ogilvie-Grant found the species on Deserta Grande, near Madeira, but obtained no eggs, though the birds were paired (Ibis, 1890, p. 444). He met with it again on Great Salvage Island in the spring of $\mathbf{1 8 9 5}$, but there again it had not commenced to lay. Padre Schmitz forwarded specimens from Porto Santo.

In the Azores I met with this Shearwater throughout the archipelago. It was breeding in holes in the cliffs about the end of May (Ibis, 1860, pp. 103, 107). Mr. Ogilvie-Grant found the species on several of the islands, and procured eggs on Villa Islet (Santa Maria) and Praya Islet, near Graciosa. It also breeds on some of the other islands, such as Flores and Pico (Nov. Zool., XII., p. 97).

Specimens from the eastern coast of North America have been described under the name of Puffinus borealis by Mr. C. B. Cory, but I cannot find any difference between individuals from the coast of Massachusetts and others from the Atlantic islands.

$P$. kuhli sometimes wanders northward like other Petrels. In the Stuttgart Museum is an example obtained near that town in October, 1891 (Sclater, Ibis, 1894, p. 107). It has once been found in England, a specimen having been picked up dead on the beach at Pevensey, in Sussex, on the 21st of February, 1906, and examined by Mr. Butterfield, who states that it belonged to the true Mediterranean form, P. kuhli, and not to the Atlantic form, $P$. flavirostris.

Mr. Whitehead describes the breeding habits of $P$. kuhli in the islands off the coasts of Corsica during the month of June. The nest consisted of a few sticks, a little seaweed, and some feathers from the bird's own breast, and was usually placed under a rock in the short scrub at some distance from the water. The birds, like other Shearwaters, bit and scratched the hands of those molesting them. A full account of the breeding of the species on the Salvage Islands is given by Mr. Ogilvie-Grant (Ibis, 1896, pp. 47-50).

Puffinus kuhli, with its white quill-lining, would, at first sight, appear to be 


\section{PUFFINUS KUHLI.}

distinguishable from $P$. flavirostris of the Atlantic, with its dark quill-lining, but for the fact that the Mediterranean birds have sometimes dark primaries, and the Atlantic birds have occasionally a certain amount of white on the quills below. It is not possible to assign definite characters to these races, for the extent of the white quilllining varies considerably in Mediterranean specimens, and although the bird from Genoa which I describe below, shows a distinct white area or "mirror" on the inner webs of the primaries, a second specimen from Genoa, also collected by the late Edward Cavendish Taylor, in the same month of July, has no great extent of white lining to the inner webs of the primaries, the quills being dark below, only showing a little white towards the base. The marking on the wings in this individual is not symmetrical, for whereas the left wing has the inner web of the first primary uniform ashy-grey, and white only at the extreme base, the first primary of the right wing is ashygrey below, white at the base of the inner web to half-way down the feather, and mottled with ashy-grey.

Adult. General colour above ashy-brown, the upper-surface mottled with dark brown feathers, all of which are plainly margined with ashy-grey, especially on the scapulars and inner secondaries; hind-neck more uniform ashy-grey; upper tailcoverts brown, with hoary-whitish edges; wing-coverts dark brown, edged with lighter brown; quills blackish, with a slight shade of ashy on the secondaries, which have a good deal of white on the inner webs, the primaries having the outer web blackish, the black occupying the portion of the inner web adjacent to the quill, as well as the end of the feather, this black being prolonged as a distinct margin along the inner web, leaving a large wedge-shaped white lining; tail-feathers blackish above, ashy below; crown of head dusky-brown, a little darker than the back, and shaded with white in front of the eye, which has the eyelid white; cheeks and sides of neck ashy-grey, with frecklings of ashy bars and spots, where these parts adjoin the white under-surface; the chin also with a few greyish spots ; entire under-surface of body white, including the under tail-coverts, a few of the feathers near the thigh freckled with ashy-brown, some of them also externally ashy-brown, but not forming a conspicuous patch; under wing-coverts and axillaries with a broad blackish band round the edge of the wing; quills dusky-black below, with a distinct quill-lining of white. Total length about 15 inches ; culmen, 1.5 ; wing, 13.1 ; tail, 4.9 ; tarsus, 1.9 ; middle toe and claw, 2.6.

The following is a summary of the measurements of specimens examined by me in the British Museum and the Rothschild Museum :-

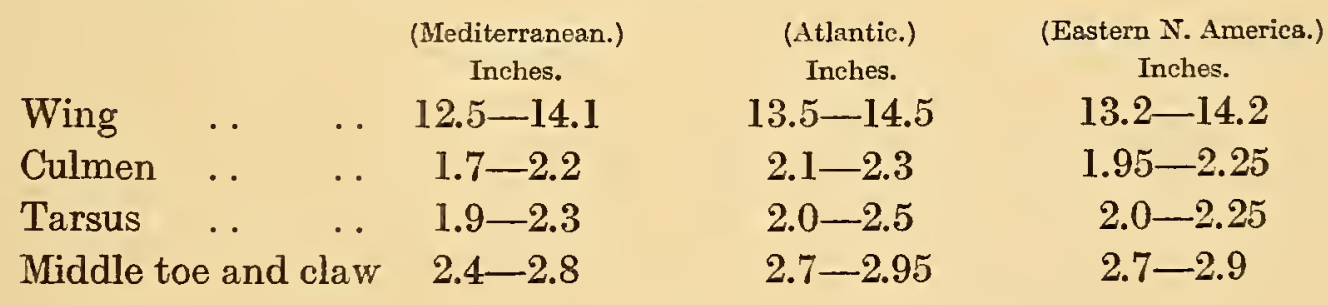




\section{MONOGRAPH OF THE PETRELS.}

The males are generally a little larger than the females. The variation in the amount of the white quill-lining in the true $P$. kuhli of the Mediterranean has been already alluded to, and in the Atlantic birds an equal variation is met with. Thus, a specimen from Porto Santo, obtained by Padre Schmitz, ought to have a dark quilllining, but shows some white on the second and third primaries, which extends more than half-way down the quill. A Tenerife specimen is similar.

The records of the colours of the bill and feet vary to a considerable extent. Those in a specimen from the Azores are given by Mr. Ogilvie-Grant as follows :- "Bill yellowish-horn, the nostrils and tip of rhampotheca dusky; legs pale fleshcolour, blackish on outer side of tarsus, outer toe, joints, and webs." A bird obtained by the same observer on Great Salvage Island had the "bill dirtyyellow, the culmen and the tips of the cutting-edges blackish-brown; legs pale flesh-colour; outer toe-joints and webs dusky; inner toe and nail very pale flesh-colour; iris dark brownish-black." Another bird, from Deserta Grande, is recorded by Mr. Ogilvie-Grant as having the "bill dull yellow, darker towards the tip; legs and feet pale pink, the outer toe and the webs dusky; iris dark brown." In the type of $P$. borealis from Cape Cod, Mr. C. B. Cory states that the bill was "pale yellowish at the base, shading into greenish-black, but again becoming pale near the tip : outside of feet greenish-black, the inside and webs dull orange."

The specimen described is one obtained by the late Edward Cavendish Taylor near Genoa, and now in the British Museum. The bird figured was procured by myself in the Azores. 


\section{PUFFINUS EDWARDSI, Oustalet.}

\section{(CAPE VERDE ISLANDS SHEARWATER.)}

Puffinus edwardsi, Oustalet, Ann. Sci. Nat. (6), XVI., Art. V., p. 1 (1883).

Puffinus marice, Boyd Alexander, Ibis, 1898, pp. 92, 108, 109.

$P$. Kuhli similis, sed minor; subtus albus, minime griseo marmoratus vel vermiculatus, faciei tamen et colli lateribus griseo marmoratis : axillaribus albis : remigibus intus griseo-brunneis, minime albis.

THIs species was originally described by the late Dr. Oustalet from the island of Branca, in the Cape Verde Archipelago. Dr. Oustalet's description was overlooked at the time, and Lieut. Boyd Alexander, who visited the islands in March, 1897, and met with the species on Brava, Raza, and Branca, named it P. marice. Further individuals were obtained by him on the way to the Rombos Islands, but, contrary to expectation, none were found inhabiting the rocks of that group.

$P$. edwardsi is nearly allied to $P$. kuhli, but differs in size, and must be considered to be distinct. The following measurements, taken from specimens collected by Lieut. Boyd Alexander, prove that $P$. edwardsi is decidedly smaller than $P$. kuhli. The dimensions of specimens measured in the flesh are recorded by him as follows :-

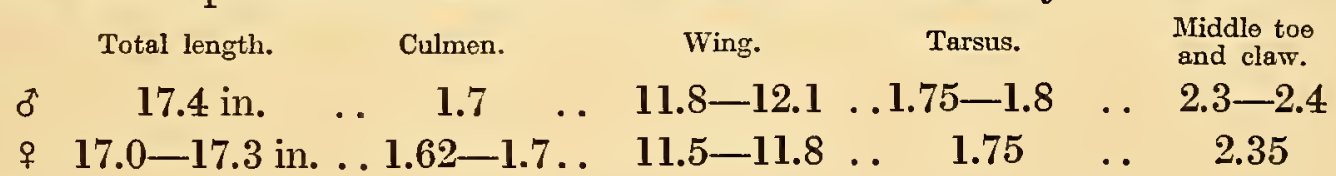

The specimens in the British Museum and in the collection of the Hon. Walter Rothschild, obtained by Lieut. Boyd Alexander, give the following dimensions :-

$\delta$ Wing, 11.95-12.1 inches; culmen, 1.7-1.85; tarsus, 1.8-1.85; middle toe and claw, 2.2-2.4.

o Wing, 11.6-12.1 inches; culmen, 1.7-1.75; tarsus, 1.75-1.8 in.; middle toe and claw, 2.25-2.45.

In addition to the smaller size and more slender bill, Lieut. Boyd Alexander points out that $P$. edwardsi differs from $P$. kuhli in colour, having the crown and neck much darker, and of a deep sooty-grey tint.

He has given the following account of the species in the Cape Verde Islands :- 


\section{MONOGRAPH OF THE PETRELS.}

"Raza and Branca may be looked upon as the chief habitat of this species. Before landing on Raza, we saw a large flock in a wedge-shaped formation sleeping on the water. They frequent chiefly the hollows in the cliffs, but we found some on the higher ground in holes made by the birds themselves underneath large boulders, where the entrances were strewn with small stones and flakes of rock, evidently brought there by the birds, since the soil is of a fine nature."

"These Shearwaters appear to prey upon smaller birds, for in many instances the vicinity of their holes was strewn with bones and feathers. While on Brava, we constantly heard this bird at night among the hills; its weird cry, only enhanced by the silence, is like the whistling cry of the Widgeon. When fishermen land on Raza, they capture many of these birds for eating purposes, sometimes taking away almost a boat-load to their homes" (Ibis, 1898, p. 108).

The breeding-place of $P$. edwardsi has not yet been determined, but it is doubtless to be sought for on some of the Cape Verde Islands.

The species is so closely allied to $P$. kuhli that it has not been considered necessary to give a separate Plate. 


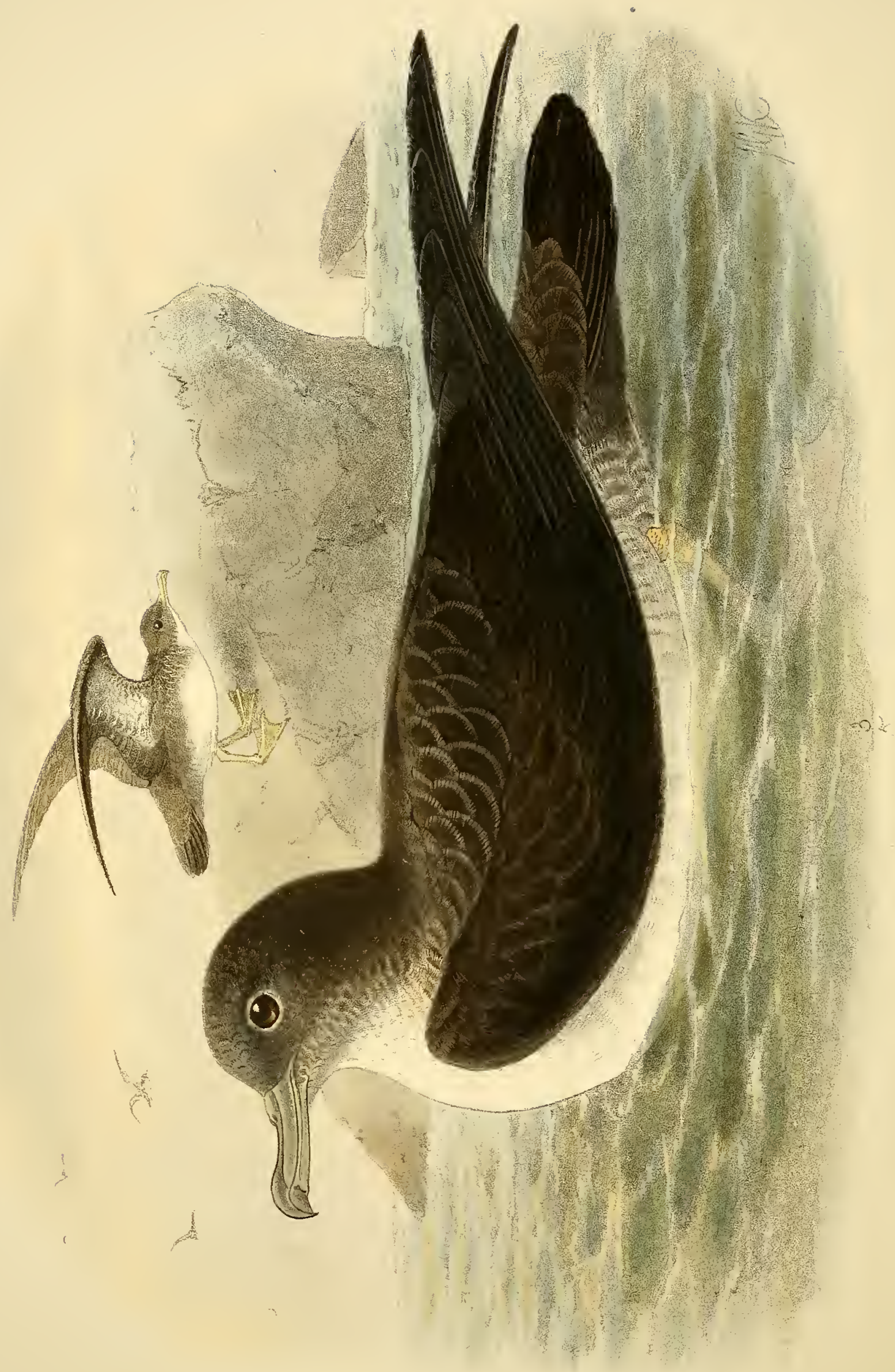




\title{
33. PUFFINUS CREATOPUS, Coues.
}

\author{
(PINK-FOOTED SHEARWATER.)
}

(Plate 27.)

Puffinus creatopus, Coues, Pr. Acad. Philad., 1864, pp. 131, 144, 1866, p. 192 ; Baird, Brewer, and Ridgway, Water-Birds N. Amer., II., p. 383 (1884); Salvin, Cat. Birds Brit. Mus., XXV., p. 376 (1896).

Cauda rotundata, vix cuneata, rectricibus centralibus 4.4-4.65 poll. ; notæo brunneo, fere concolori : subcaudalibus saturate fumoso-brunneis: colli lateribus cinerascentibrunneo marmoratis.

Puffinus creatopus is the Pacific representative of $P$. kuhli. It is a large species, having a wing from 12.2-13.0 inches in length, and is distinguished from $P$. kuhli by the black tip to the bill and the general sooty colour of the axillaries and under tail-coverts. The upper-surface is nearly uniform brown, with the light edgings to the dorsal feathers scarcely distinguishable; the upper tail-coverts are also uniform dark brown, without any white margins, as in $P$. kuhli.

This Shearwater, moreover, differs from all its allies in the colour of the under tail-coverts, which are sooty-brown, not white. The axillaries in $P$. creatopus are also sooty or lavender-brown, sometimes with white bases, and occasionally with white tips, the latter often mottled with dusky brown or with dusky shaft-lines. In $P$. kuhli and $P$. edwardsi the axillaries are white.

The species was first described by the late Dr. Elliot Coues, from a specimen procured by Dr. Cooper on San Nicholas Island, off California. An example from the vicinity of Monterey, obtained by Mr. Alvin Seale in June, is in the British Museum ; and others from the same locality, procured by Mr. Maillard in August, are in the Rothschild Collection. Mr. Loomis, in his essay on the "Water Birds of California" (Pr. Calif. Acad. Sci. (2), V., p. 216, 1895), says that the Pink-footed Shearwater was observed off Monterey as a passing migrant in August, but was not abundant, the first bird being observed on the 31st of July. Mr. Grinnell states that several Shearwaters seen between Catalina and Santa Barbara Islands in the spring of 1897, were believed to be $P$. creatopus (Publ. Pasadena Acad., I., p. 24, 1897). 


\section{MONOGRAPH OF THE PETRELS.}

That these Shearwaters pass on migration along the coasts of Central America, towards the Southern Pacific Ocean, is doubtless the case ; but, as a fact, there are no further records of the species until the Chilian coast is reached. The Rothschild Museum contains specimens from Chile, collected by Mr. Charles S. Reed, at Talcahuano, Peuco, and San Vicente, in November, December, and May. Mr. E. C. Reed has forwarded examples from Juan Fernandez (Salvin, Ibis, 1875, p. 377). Admiral A. H. Markham procured a male in Coquimbo Bay in November (Salvin, P. Z. S., 1883, p. 431), and Mr. A. A. Lane another, at Corral, in Chile.

During the cruise of the Earl of Crawford's yacht, the "Valhalla," Mr. M. J. Nicoll obtained a specimen in Valparaiso Bay in February. He says that the species was not uncommon, but very shy, and difficult to shoot (Ibis, 1904, p. 51).

Adult male. General colour above uniform dark brown, with scarcely any sign of lighter edgings to the feathers beyond a few obsolete hoary-whitish margins on the inner secondaries and scapulars, the latter being blackish, like the inner secondaries; wing-coverts like the back, the greater series shaded externally with ashy-grey, and narrowly fringed with a whitish margin at their ends; primary-coverts and quills black, browner on the inner web, and having a slight shade of hoary-grey, scarcely distinguishable on the primaries, but evident on the outer web of the secondaries, which have a slight fringe of white at the ends, like the greater coverts; tail-feathers black; crown of head, hind-neck, and sides of neck, uniform dark brown, a trifle darker than the back; lores and sides of face dusky-brown, slightly mottled with ashy, especially below the eye ; upper and lower margins of eye white ; cheeks ashygrey, mottled with dusky spots, this mottling continued in the form of spots and bars along the sides of the neck to the sides of the upper breast; under-surface white, the entire sides of the body mottled and freckled with dusky ashy-brown, or blackish, bars near the ends of the feathers, some of which are entirely dusky at the tips; above the thighs a patch of slaty-brown; the lower abdomen slightly mottled with dusky-brown bars; under tail-coverts blackish-brown, with faint edges of lighter brown, almost obsolete ; central bunch of coverts ashy-brown, more plainly edged with hoary-white, those near the vent white, with wavy bars of dusky-brown near the tips ; under wing-coverts white, mottled on the inner edge with dusky-black centres to the feathers, often in the form of spear-shaped spots ; round the carpal bend of the wing, a black bar, more or less broken ; lower primary-coverts white, with a good deal of black on the outer webs, and sometimes a patch at the end of the inner web; lesser axillaries white, with dusky bars like the adjacent under wing-coverts; longer axillaries black or ashy-brown, with narrow white tips and more or less white at the base ; quills dark brown below, slightly more ashy on the inner webs ; "bill yellowish flesh-colour, the tip black; tarsi and feet flesh-colour, the outer toe darker; iris hazel " (M. J. Nicoll). Total length about 20 inches; culmen, 1.7 ; wing, 13.0 ; tail, 4.4 ; tarsus, 2.1 ; middle toe and claw, 2.6. 


\section{PUFFINUS CREATOPUS.}

Dr. Elliot Coues gives the soft parts in the typical specimen from San Nicholas Island, as follows :- "Culmen and margins of the bill brownish-black, the rest of the bill light yellowish flesh-colour ; legs and feet entirely light flesh-colour; claws whitish with brown tips."

As is the case with many of the white-breasted Shearwaters, $P$. creatopus appears to have a dusky phase of plumage, but, judging from the specimens examined by me, this is not so pronounced nor so uniform as in some of the allied species. Many examples have the under-surface freckled with dusky-grey; others, however, have dusky frecklings and bars on the abdomen, which occasionally extend over the entire breast. The frecklings on the side of the neck vary in intensity, and are more pronounced in those specimens which incline to a dusky under-surface.

The description is taken from the male procured by Admiral A. H. Markham, in Coquimbo Bay, and in our collection. The same specimen has been figured in the Plate. 


\section{PUFFINUS ANGLORUM (Kuhl). \\ (MANX SHEARWATER.)}

(Plate 28.)

The Puffin of the Isle of Man, Edwards, Gleanings Nat. Hist., III., p. 313, Pl. 359 (1764).

Le Puffin, Briss., Orn., VI., p. 131 (1760).

Procellaria puffinus, Linn., Syst. Nat., I., p. 213 (1766).

Shearwater, Penn., Arctic Zool., II., p. 535 (1785); id. Brit. Zool., II., p. 206 (1812).

Shearwater Petrel, Lath., Gen. Syn., III., Pt. 2, p. 406 (1785).

Le Petrel Puffin, pt. Buffon, Hist. Nat. Ois., IX., p. 321 (1783).

Nectris anglorum, Kuhl, Beitr., p. 146 (1820).

Puffinus anglorum, Temm., Man. d'Orn., II., p. 806 (1820) ; Boie, Isis, 1822, p. 562 ; Audub., Orn. Biogr., III., p. 620 (1835) ; Coues, Pr. Acad. Philad., 1864, pp. 134, 144; Saunders, ed. Yarr., Brit. Birds, IV., p. 21 (1884); Salvin, Cat. Birds Brit. Mus., XXV., p. 377 (1896).

Puffinus arcticus, Faber, Prodr. Isl. Orn., p. 156 (1822).

Mank's Shearwater, Lath., Gen. Hist. Birds, X., p. 184 (1824).

Thalassidroma anglorum, Swains., Classif. Birds, II., p. 374 (1837).

Nectris puffinus, Keys. \& Blas., Wirb. Eur., p. xciv. (1840).

Cymotomus anglorum, Macgill., Man. Brit. Birds, II., p. 13 (1842).

Manx Shearwater, Yarrell, Brit. Birds, III., p. 508 (1843).

Puffinus puffinus, A. O. U. Checklist, N. Amer. Birds, 1886, p. 100 ; Ridgway, Man.

N. Amer. Birds, p. 60 (1887); Sharpe, Handb. Brit. Birds, IV., p. 163 (1897).

Cauda breviore, rotundata : subtus albus : ala 8.9-9.5 poll. : axillaribus albis, macula nigra subterminali notatis: subcaudalibus et hypochondriis albis, minime brunneis, sed interdum nigro maculatis vel striatis.

The Manx Shearwater belongs to the smaller section of the genus Puffinus, in which the wing does not exceed 9.6 inches in length. The axillaries are white, with a black spot at the end, the flanks being also white, sometimes with a little blackish freckling, but 


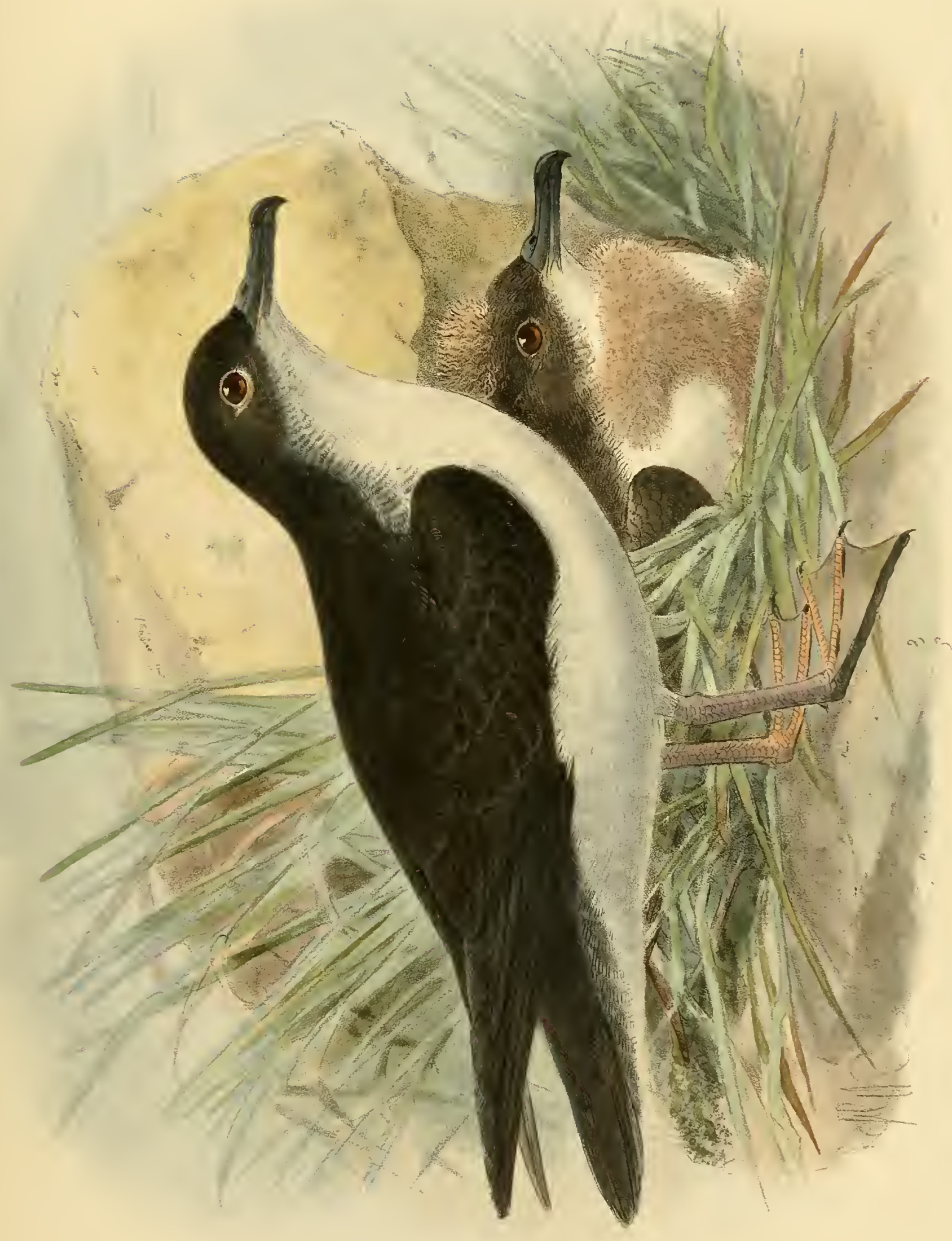




\section{PUFFINUS ANGLORUM.}

without the brown shading of $P$. yelkouanus. The under tail-coverts are white, but they often show a slight brown mottling, approaching those of the latter species.

$P$. anglorum is found in all the British seas, but is chiefly restricted, during the breeding season, to certain rocks and islands on the western coasts of Great Britain. It breeds in the Orkney and Shetland Islands in April and May, as well as on the Inner and Outer Hebrides. Mr. Howard Saunders states that, until a comparatively recent date, it was abundant on the "Calf" of Man (Manual Brit. Birds, 2nd ed., p. 741). The Manx Shearwater also nests on some of the islands off the coast of Wales, as well as on the Scilly Islands. In Ireland, according to Mr. R. J. Ussher, it breeds on the headlands and islands of Donegal, Antrim, Dublin, Wicklow, Wexford, Kerry, and Mayo, and probably in other counties. In Heligoland, according to Gätke, it was formerly plentiful, but of late years it has entirely disappeared.

Another breeding place of $P$. anglorum is on the Faeroes, and it has been recorded as an incidental visitor to the coasts of Norway. It occurs also in some numbers in the south-west of Iceland, and has been noted from South Greenland.

I obtained two specimens from the Azores in May, when it was apparently breeding in the cliffs ; the birds were known there as "Stapagardo," but $P$. anglorum was not so plentiful as P. kuhli (Ibis, 1866, p. 104).

Mr. J. J. Dalgleish records this bird from Madeira (Pr. Roy. Phys. Soc. Edinb., XI., p. 27), and Mr. Meade-Waldo states that the "Pardela" is not uncommon, in winter, in the vicinity of the Canary Islands, where, however, it does not come near the coast (Ibis, 1893, p. 206). The Rothschild Collection contains a specimen from Tenerife, procured by Ramon Gomez, which is undoubtedly the true $P$. anglorum.

In North America it is of rare occurrence, single individuals only having been met with at sea off the coasts of Maine and Nova Scotia.

Mr. Howard Saunders states that the species reaches the coast of Brazil in its winter migration, and that he presented a specimen, obtained from there, to the British Museum. The only example, however, that I can discover in the National Collection, given by Mr. Saunders, is simply labelled "Barranca Grande" (Big Gorge), without any further information as to locality.

The accounts of the habits of this Shearwater published in many works on British Ornithology, show that they do not differ materially from those of other members of the genus. The birds are crepuscular, remaining in their burrows nearly the whole of the day, and coming out in small parties after sunset, frequently gathering in larger bodies on the sea, when as many as 300 may be seen together.

The nest is merely a slight structure of dry grass placed at the end of a burrow. A single white egg is laid, of a smooth texture. Specimens in the British Museum measure: Axis, 2.4 inches; diam., 1.6.

Adult female. General colour above sooty-black, the head like the back; wings and tail also sooty-black; lores, sides of face and ear-coverts blackish, like the crown; 


\section{MONOGRAPH OF THE PETRELS.}

eyelid white above and below; cheeks for the most part white, mottled with ashygrey; sides of neck, behind the ear-coverts, also white, mottled with ashy frecklings ; throat and remainder of under-surface pure white; the sides of the lower throat, fore-neck, and chest mottled with sooty or ashy-brown, where they adjoin the sootybrown of the back; on the thighs a patch of black feathers; under-tail coverts white, some of the long lateral coverts externally sooty-black; under wing-coverts and axillaries white, the latter with a spot of ashy or sooty-black near the ends; a slight ashy-grey mottling all round the bend of the wing; quills dusky-brown below, the inner webs of a more ashy-grey shade; " bill dark horn-colour, the sheath of the under mandible greyish; back of the tarsus, outer toe, and lower outer half of middle toe black; iris dark brown; tarsus in front, and toes light pink, the webs bluish-grey, paler in the middle" (W. R. Ogilvie-Grant). Total length, 14.5 inches; culmen, 1.45; wing, 9.5 ; tail, 3.0 ; tarsus, 1.7 ; middle toe and claw, 2.15 .

Adult male. Similar in plumage to the female. Total length, 14.5 inches; culmen, 1.3 ; wing, 9.0 ; tail, 2.9 ; tarsus, 1.7 ; middle toe and claw, 1.85 .

Nestlings. Covered with sooty-brown down.

Obs. Sometimes the sub-terminal black spot on the axillaries is very large, at other times it is divided into twin-spots, and in some specimens it is very minute, suggesting that, in very old birds, it becomes evanescent and may disappear altogether with age.

Occasionally there are frecklings of black on the lower flanks, or even black streaks. It is evident, however, that these markings on the flanks and axillaries are never brown as in $P$. yelkouanus, but are always black in $P$. anglorum, and the under tail-coverts are also never brown, as in the Levantine Shearwater.

The description of the male is taken from a specimen from St. Bride's, South Wales, presented to the Museum by the late Lord Kensington; that of the female from an example in the Howard Saunders Collection, from Rathlin Island. The specimen figured is the male above recorded. 


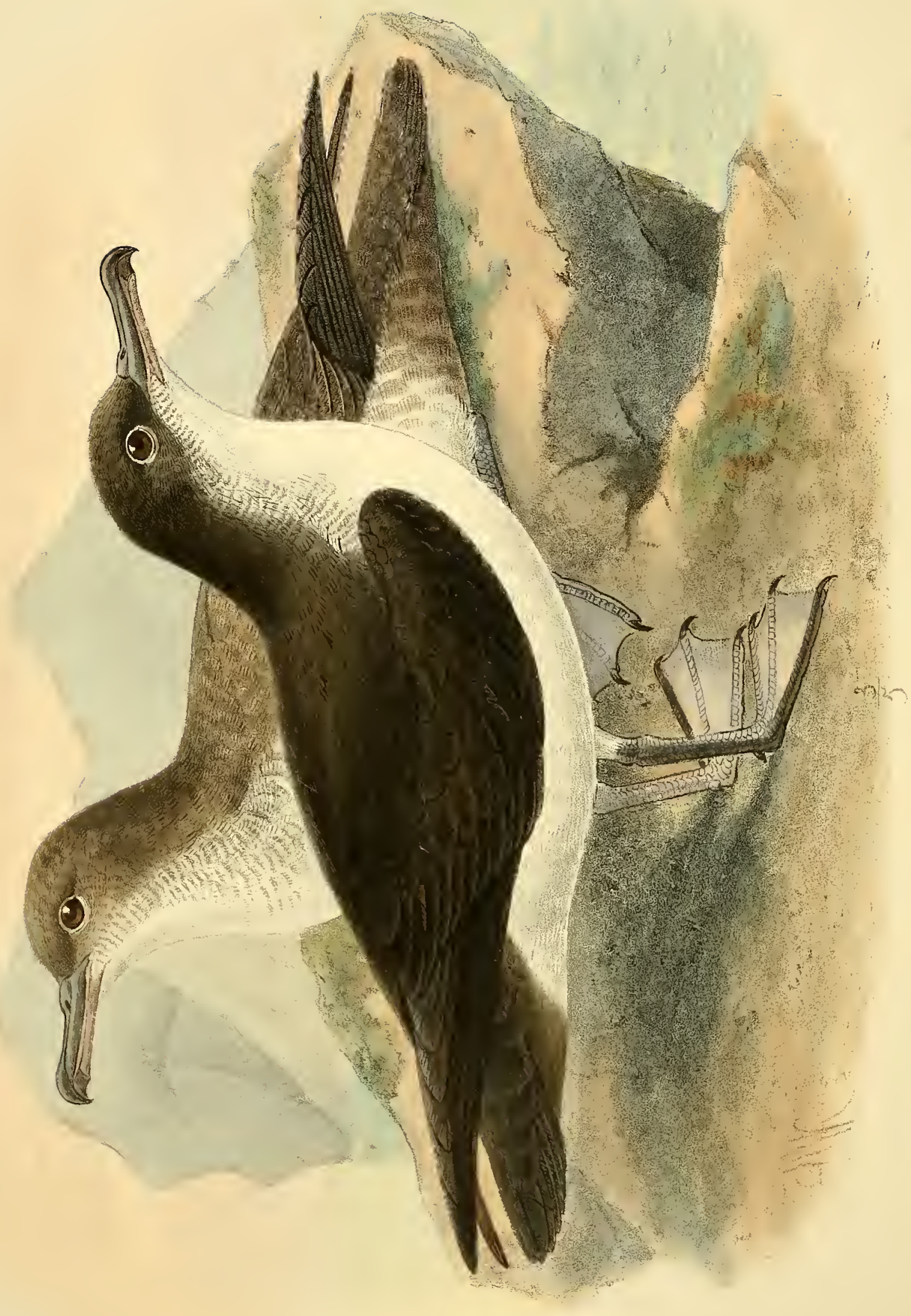




\title{
35. PUFFINUS YELKOUANUS (Acerbi).
}

(LEVANTINE SHEARWATER.)

\author{
(Plate 29.)
}

Procellaria yelkouan, Acerbi, Bibl. Ital., XLVII., p. 297 (1827).

Puffinus yelkouan, Bp., Consp. Av., II., p. 205 (1856) ; Arrigoni degli Oddi, Atl. Orn., p. 526 (1902).

Puffinus baroli (nec Bonelli), Bp., Comptes Rend., XLII., p. 769 (1856) ; Salvad., Faun. d'Italia Ucc., p. 299 ; id., Ibis, 1899, p. 641.

Puffinus anglorum (nec Kuhl), Costa, Faun. Regn. Nap. Ucc., p. 72 (1857), et auct. aliq. recent.

Puffinus yelcuanus, Coues, Pr. Acad. Philad., 1864, pp. 137, 144.

Puffinus yelkouanus, Salvin, Cat. Birds Brit. Mus., XXV., p. 379 (1896).

Cauda breviore, rotundata: subtus albus, interdum fuscescenti-brunneo lavatus: axillaribus albis, fuscescenti-brunneo terminatis vel marmoratis, rarius omnino brunneis : subcaudalibus et hypochondriis fuscescenti-brunneis.

THIs species occurs throughout the Mediterranean from Gibraltar to the shores of Palestine and Egypt, extending to the Sea of Marmora. I have examined a large series in the British Museum and in the Rothschild Collection, from the following localities : Morocco (Savile Reid) ; Oran, Algeria (G. E. Shelley) ; Malaga (Howard Saunders); Nice (E. C. Taylor); Malta (C. A. Wright); Isola Toro, Sardinia (Rothschild Mus.); Corsica (John Whitehead); Croatia (S. Brusina); Cyclades (Rothschild Mus.); Bosphorus (T. Robson; W. Pearce); Smyrna Bay, Vourla Bay, Asia Minor (C. G. Danford); foot of Mt. Carmel, Palestine (H. B. Tristram); Damietta, Egypt (Filipponi ; Mus., G. E. Shelley).

The above records embrace almost the entire range of $P$. yelkouanus. According to Count Arrigoni degli Oddi (l.c.) it is a common species in the Italian Mediterranean, and nests there; it is, however, rare in the Adriatic, especially in the Gulf of Venice, though common on the coast of Croatia. The specimens obtained in the Gulf of Lyons, though generally referred to $P$. anglorum, have all proved to be $P$. yelkouanus, and the same may be said of those procured off the coasts of the Riviera. Others 


\section{MONOGRAPH OF THE PETRELS.}

recorded as $P$. anglorum or $P$. baroli from the Eastern Mediterranean are now acknowledged to be $P$. yelkouanus. That the species sometimes wanders north from the Mediterranean is proved by its occurrence in the seas south and east of Britain. Specimens procured in August from Torbay and Plymouth Sound are in the British Museum (Salvin, Cat. Birds Brit. Mus., XXV., p. 380). One obtained off Bridlington Quay in October, 1898, is recorded by Dr. Bowdler Sharpe (Bull. B. O. C., X., p. xlviii., 1900), and another from Scarborough (February 5th, 1899) by Mr. Howard Saunders (Bull. B. O. C., VIII., p. xxix., 1899).

The name "yelkouan," bestowed on this species by Acerbi, is Turkish, and signifies "the bird of the wind." Dr. Dickson, a good authority, says that the name should rightly be "Yel-Kovan" (lit. "Wind-driver"). Cf. Sclater, "Ibis," 1876, p. 61.

From the few notes published on the habits of the Levantine Shearwater, it is evident that they resemble those of the northern $P$. anglorum and other species of the genus. Mr. John Whitehead discovered the birds nesting on the small islands off the coast of Corsica. On the 2nd of May, with the aid of a small dog, he obtained eight separate eggs, all of which were placed under piles of large rocks, which had fallen from the high cliff above. The nests were situated only a few feet from high-water mark, whereas the large Mediterranean Shearwater $(P$. kuhli) breeds under single rocks at some distance from the water (Ibis, 1885, p. 48).

An egg procured by Mr. Whitehead, and presented by him to the British Museum, is white, and measures: Axis, 2.35 inches ; diam., 1.65.

$P$. yelkouanus is the Mediterranean representative of $P$. anglorum, but is browner on the upper-surface, and is distinguished by its brown under tail-coverts, and by the brown colour of the flanks. This brown shade sometimes extends over the sides of the body and abdomen, and occasionally over the whole under-surface, as seen in a specimen from Malaga in the Howard Saunders Collection, and in others from the Mediterranean examined by me. The axillaries are also brown, or ashy-brown, with white bases, but occasionally they are white, mottled with brown. In $P$. anglorum the axillaries are white, with a sub-terminal black tip, but so much variation takes place in the dusky mottling of the under tail-coverts and sides of the body that the two species somewhat intergrade.

In a specimen obtained off the Algerian coast on the 24th of February, 1873, Captain G. E. Shelley records the soft parts as follows: "Legs fleshy white; outside of tarsus, outside of outer toe and nails, black; bill black, shaded with fleshy white on the lower mandible below; iris brownish black." Mr. C. G. Danford records specimens from Vourla Bay, in Asia Minor, as having the bill " pinkish or fleshy black; legs flesh-colour, the outer toe darker, like the bill."

The birds described are in the British Museum. The figure in the Plate is drawn from the specimen obtained by Mr. J. E. Harting, at Torbay, in Devonshire, in August, 1875, and now in our own collection. 



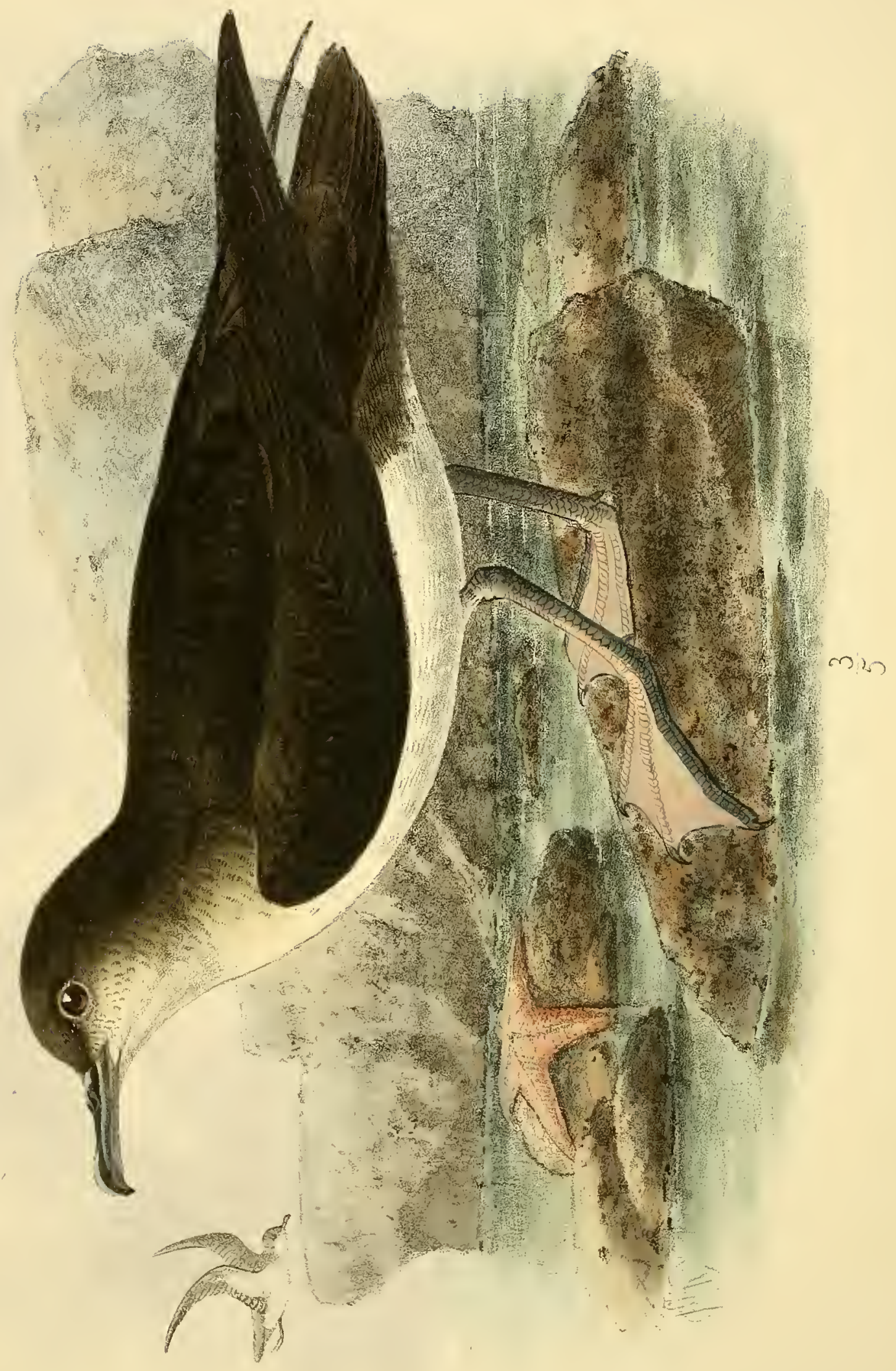




\title{
36. PUFFINUS OPISTHOMELAS, Coues.
}

\author{
(BLACK-VENTED SHEARWATER.)
}

(Plate 30.)

Puffinus opisthomelas, Coues, Pr. Acad. Philad., 1864, pp. 139, 144; Salvin, Cat. Birds Brit. Mus., XXV., p. 380 (1896); Anthony, Auk, XVII., p. 247 (1900) ; Godman, Biol. Centr.-Amer., Aves., III., p. 434, note (1904).

Puffinus gavia (nec Forst.), Ridgway, Pr. U. S. Nat. Mus., III., pp. 12, 230 (1880) ; id. in Baird, Brewer, and Ridgway, Water-Birds N. Amer., II., p. 389 (1884); A. O. U. Checklist, N. Amer. Birds, 2nd ed., p. 32 (1895).

Cauda breviore, rotundata: subtus albus: axillaribus albis, fuliginoso-brunneo terminatis, vel fuliginosis, basin versus albis: subcaudalibus et hypochondriis imis nigricantibus: gutturis et colli lateribus cinerascenti-brunneo marmoratis.

IT has not hitherto been remarked that $P$. opisthomelas bears a strong resemblance to $P$. yelkouanus of the Mediterranean, but this is undoubtedly the case. It differs from the latter in its slightly larger size, blacker under tail-coverts, and in the greater amount of brown mottling on the sides of the throat and neck, which sometimes extends across the latter, while the axillaries are white, with dusky ends. The range of $P$. opisthomelas being restricted to the Pacific coast of America, its evident affinity with a. European species is a fact of singular interest.

The first recorded specimens were procured by the late John Xantus, off Cape St. Lucas, in Lower California. They were described by the late Professor Elliot Coues, but for some time the species was considered to be identical with $P$. gavia. The latter, however, has white under tail-coverts, and $P$. opisthomelas is now recognised as distinct.

Mr. A. W. Anthony, who has done so much to acquaint us with the habits and distribution of the Pacific Shearwaters, says (Auk, XVII., p. 247, 1900) that $P$. opisthomelas is the most abundant species of the genus in western North America, and that it is plentiful off the coast of Central California during the summer months, being found at all seasons of the year south of the Santa Barbara Islands. Of its northern range he was not quite certain, but considered that he had seen the species off the 


\section{MONOGRAPH OF THE PETRELS.}

Columbia River in November. Mr. Ridgway, writing in 1884 (Water-Birds N. Amer., II., p. 389), believed that it occurred along the entire Pacific coast, as far north, at least, as Oregon.

Mr. Anthony further remarks (l.c.) that, although Major Bendire informed him that there were two or three eggs in the U. S. National Museum, said to have been taken on one of the Santa Barbara Islands, he doubted the fact, as the larger islands were so infested with foxes that the birds would have been exterminated ; they might, however, possibly breed on some of the smaller islands where these animals did not exist, and Mr. Grinnell confirms this view. Mr. Anthony also states that the Black-vented Shearwater is not met with until the island of Guadalupe is reached, about 200 miles south of the United States boundary, where he found it breeding plentifully. On the San Benito Islands, lying between Guadalupe and the Cerros Islands, a few pairs were nesting, whilst in August on Natividad Island, about 35 miles south of San Benito, the birds returned in thousands to roost. Numerous fresh tracks were observed outside the burrows, showing the imprint of the tarsus for its full length, from which it was evident that the birds placed their weight on the tarsus as well as on the toes.

To Mr. Anthony we are also indebted for an account of the nesting of $P$. opisthomelas. In Guadalupe the burrows were dug under huge blocks of lava, but on the San Benito Islands the nests were situated in small caves, which were nearly filled with deposits of guano, the accumulation of years. The nests were inaccessible, but every cave appeared to have been inhabited by several pairs of birds, judging from the outcry and warning hisses made when the entrance was approached. When revisiting Natividad Island on the 10th of April, 1897, each burrow was tenanted by a pair of Shearwaters, or a single bird with its egg. The burrows were seldom straight, usually 10 feet long, and only about 18 inches below the surface of the ground. The egg was either placed on a rude structure of a nest, or in a slight depression, at various distances between the entrance and the end of the hole. Eggs from Natividad Island are white, and measure : Axis, 2.25-2.8 inches; diam., 1.6-1.65.

Adult male. General colour above sooty-brown, faintly mottled on the mantle and hind-neck, but less so on the rest of the upper-surface, the feathers of the back being more or less white at the base, and having an indistinct edging of ashy-grey; the lower back, rump, and upper tail-coverts uniformly black, with obsolete ashy margins; wing-coverts, scapulars, and innermost secondaries like the back; the primary-coverts and quills black, with narrow fringes of ashy-white at the ends of the latter ; tail-feathers black; head sooty-brown, like the back, and not contrasting with the latter; lores and sides of face like the crown, slightly mottled with white; below the eye a small white mark; under-surface of body pure white, but mottled with ashybrown on the cheeks, and on the sides of the throat and chest, where the brown back and white under-surface meet; these brown mottlings broken up on the sides of the lower throat, and extending nearly across the latter; the sides of the lower flanks 


\section{PUFFINUS OPISTHOMELAS.}

uniform sooty-brown above the thighs; under tail-coverts sooty-brown, with obsolete white fringes at the tips, the central bunch near the vent white, with brown tips; under wing-coverts white, mottled with brown edgings to the marginal series, more distinct on the inner greater coverts ; quills blackish-brown below, somewhat more ashy on the inner webs, which are white at the extreme base; axillaries white, sooty-brown towards the ends, and edged with white at the tip; "nasal tubes and culmen blackish; sides of bill yellowish or reddish brown, the margins bluish-white; internal aspect, and part of the side of the outer tarsus, middle and inner toes and webs light yellowish flesh-colour ; rest of tarsus and toes brownish-black ; claws brown ; iris dark brown" (J. Xantus). Total length about 13.3 inches; culmen, 1.45 ; wing, 9.5 ; tail, 3.3 ; tarsus, 1.7 ; middle toe and claw, 2.1.

Adult female. Similar to the male. Total length 14.5 inches ; culmen, 1.4 ; wing, 9.4; tail, 3.1 ; tarsus, 1.65 ; middle toe and claw, 1.9.

The description of the male is taken from an example from Santa Cruz, California, received from Mr. C. K. Worthen, now in our collection. The female is from Monterey, California, and was obtained by Mr. Alvin Seale, and is also in the British Museum. The figure in the Plate has been drawn from one of the above specimens. 


\section{PUFFINUS AURICULARIS, Townsend.}

\section{(TOWNSEND'S SHEARWATER.)}

(Plate 31.)

Puffinus auricularis, Townsend, Pr. U. S. Nat. Mus., XIII., p. 133 (1890); Salvin, Cat. Birds Brit. Mus., XXV., p. 380 (1896) ; Anthony, Auk, XV., pp. 38, 313, 316, 317 (1898), XVII., p. 249 (1900) ; Rothschild and Hartert, Nov. Zool., VI., p. 197 (1899) ; Godman, Biol. Centr.-Amer., Aves, III., p. 434 (1904).

Cauda brevi, rotundata: subtus albus: ala breviore, 9.0-9.9 poll.: axillaribus plerumque albis : subcaudalibus fumoso-nigris.

THIs species is allied to $P$. opisthomelas, but is much blacker, has white axillaries, and, from its smaller size, approaches the Shearwaters of the $P$. obscurus group, in juxtaposition to which it has been placed by the Hon. Walter Rothschild and Dr. Hartert.

Salvin (Cat. Birds Brit. Mus., XXV., p. 380) described the type-specimen, which was kindly lent to him by the U. S. National Museum, and he states that the axillaries are white; but I find that, in a pair of birds from Clarion Island, in the Rothschild Collection, the axillaries, though white, have sub-terminal black spots.

This Shearwater was described by Dr. C. H. Townsend from a specimen obtained by him on Clarion Island, off the coast of N.W. Mexico, on 4th March, 1889, and I have seen a pair of birds in the Rothschild Museum from the same locality; the latter were obtained by Mr. R. H. Beck, in October and November, 1900, who also procured a third example at sea in January, 1897 , in Lat. $21^{\circ} 10^{\prime} \mathrm{S}$., Long. $115^{\circ} 38^{\prime} \mathrm{W}$.

About Cape St. Lucas Mr. Anthony found $P$. auricularis not uncommon, and he remarks that, although perfectly distinct from $P$. opisthomelas, it is closely allied to that species, and has a similar breeding season. At San Benedicto Island he found several birds nesting during the last week in May, when most of the young were only a few days old, covered with sooty down above and pale grey below. The burrows were on the higher part of the island, about 500 feet above the sea, somewhat scattered amongst bunches of tangled grass, a dozen or more forming a large colony; they were about half the size of those of $P$. opisthomelas on Natividad Island, 


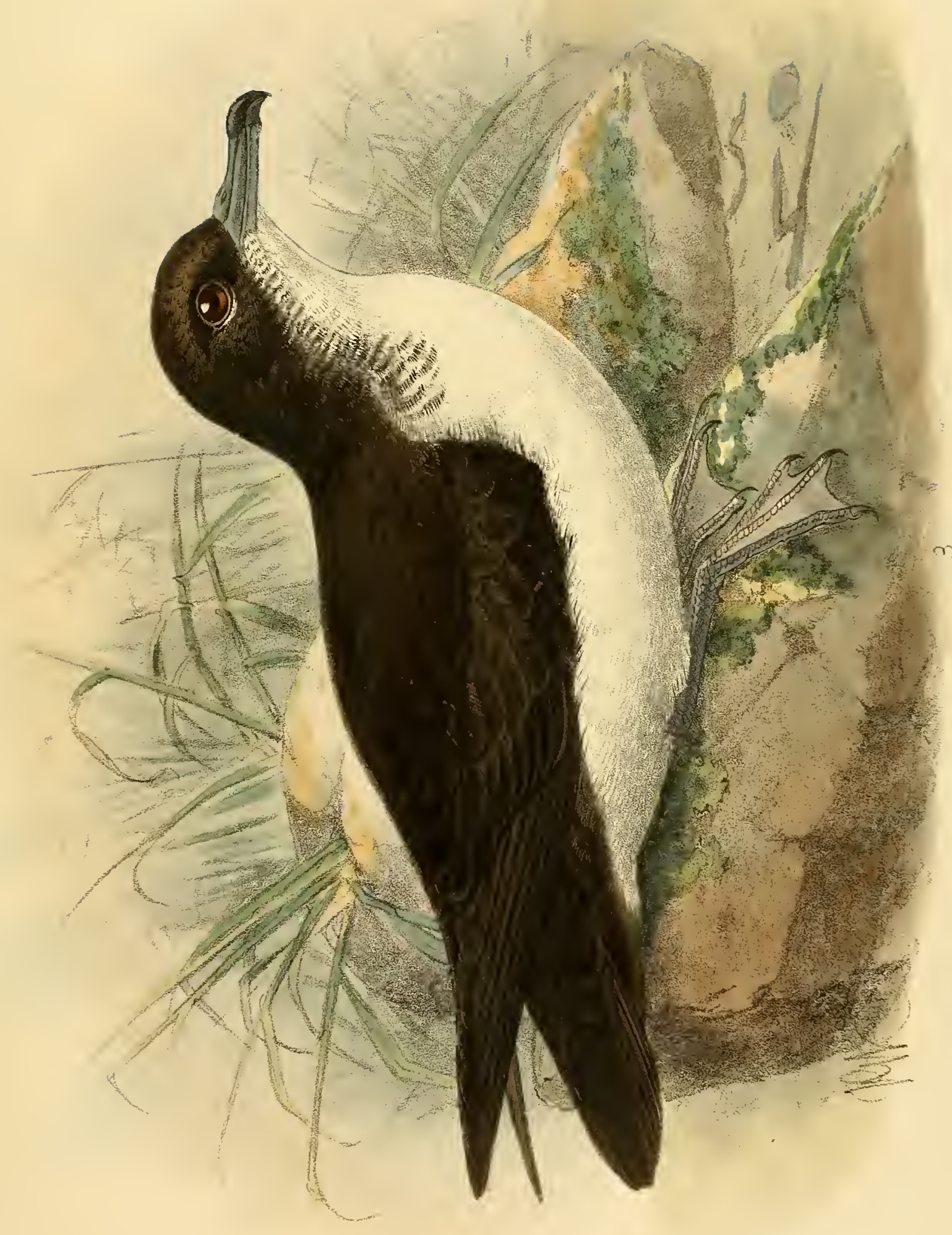

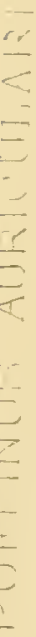





\section{PUFFINUS AURICULARIS.}

averaging about 5 feet in length. On Clarion Island, though the situation of the burrows was similar to that on San Benedicto Island, the colonies were more extensive. Few birds were seen at sea during the daytime, and those that visited the nests at night were much more silent than $P$. opisthomelas, but the cry of the two birds was very much alike (Auk, 1900, pp. 249, 250). Although observed at sea near Socorro, Mr. Anthony found no trace of the birds nesting there.

Adult female. General colour above sooty-black, the feathers of the back and scapulars with obsolete narrow margins of sooty-brown; the lower back, rump, and upper tail-coverts sooty-black, but with a slight shade of ashy ; wing-coverts sooty-black, like the back; quills black, browner on the inner webs; tail-feathers black; head and back sooty-black like the back, but more uniform than the latter, and without any trace of paler edges; lores, feathers below the eyes, and ear-coverts sooty-black, with a white mark below the eye; cheeks and entire under-surface of body pure white, with a few tiny streaks or spots of black on the cheeks and sides of the throat; the fore-neck mottled with black, the feathers being black or ashy-black, with white edges where the white under-surface is separated from the black back; a black patch on the lower flanks above the thigh; under tail-coverts sooty-black, the central ones near the vent being tipped or mottled with white at the ends; under wing-coverts white, with a moderately distinct black bar, formed by the marginal coverts round the edge of the wing, these feathers being white with a black shaft-streak and black outer web; lower primary-coverts also white, with a black outer web; axillaries pure white; quills dusky below, slightly more ashy on the inner webs. Total length about 13.5 inches; culmen, 1.25 ; wing, 8.8 ; tail, 2.95 ; tarsus, 1.8 ; middle toe and claw, 1.95 .

Adult male. Similar to the female in colour. Total length 13.5 inches; culmen, 1.35 ; wing, 9.2 ; tail, 3.15 ; tarsus, 1.8 ; middle toe and claw, 2.0.

There seems to be no difference in the sexes as regards colour or markings in adult birds, but both the females examined have narrow white fringes to the outer greater wing-coverts, which may be a sign of immaturity. They also have an obsolete brown margin to some of the feathers of the back, probably due to worn plumage.

There is, at present, no specimen of $P$. auricularis in the British Museum, but I am indebted to the Hon. Walter Rothschild for the loan of the three specimens in his collection. Salvin came to the conclusion that the bill and feet were sinaller in $P$. auricularis than in $P$. opisthomelas, but that there is not much difference in the latter is proved by the following measurements of the specimens in the Rothschild Collection :-

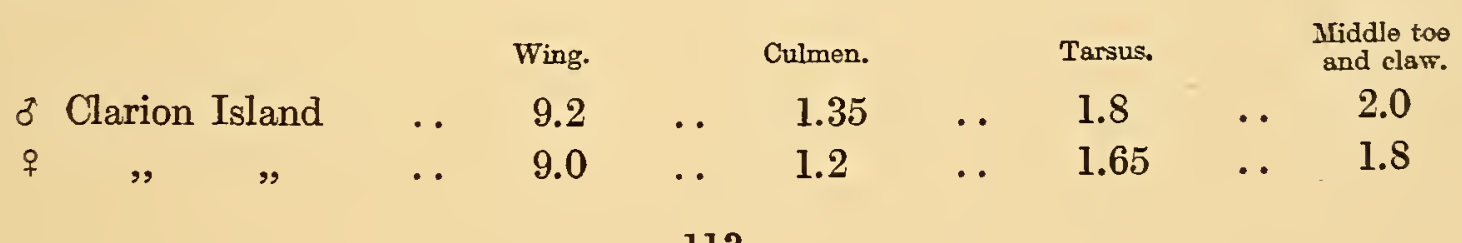




\section{MONOGRAPH OF THE PETRELS.}

The description is taken from the female obtained by Mr. R. H. Beck in the Pacific (vide suprà). The male is from Clarion Island, and both birds are in the Rothschild Collection. The figure in the Plate has been drawn from one of the typical specimens in the U. S. National Museum (Cf. Salvin, Cat. Birds Brit. Mus., XXV., p. 380). The colour of the feet and bill have not yet been described. 


\title{
38. PUFFINUS NEWELLI, Henshar.
}

\author{
(ULANI SHEARWATER.)
}

Puffinus newelli, Henshaw, Auk, XVII., p. 246 (1900) : Rothsch., Extinct Birds, p. xii. (1907).

$P$. auriculari similis, sed linea colli lateralis, superne nigra, inferne alba, absolutè definita, et subcaudalibus centralibus albis distinguendus.

THIS species was described by Mr. H. W. Henshaw from a specimen obtained by Mr. M. Newell of Hilo (Brother Mathias of the Catholic Brotherhood), in Waihee Valley, on the island of Ulani, in the spring of 1894. It was taken from its burrow by the natives, along with several others, and two specimens were preserved. The type was given to Mr. Henshaw ; the other he believes to be still extant in Honolulu.

The following is the original description (l.c.):- "Above, including upper surface of wings and tail, clear and somewhat glossy black; border of under wingcoverts black; beneath, including under tail-coverts, pure white; maxilla and edge and tip of mandible black; rest of mandible light brown; tarsus and feet light yellow, but black along the outer posterior side of tarsus, the outer toe, and half the middle toe. Wing, 8.65 inches ; tail, 3.75 ; bill, 1.28 ; tarsus, $1.80 . "$

Mr. Henshaw states that in the year 1894 the species was numerous in the island of Ulani, one of the Hawaiian group, but its present status is doubtful, for the Mongoose, which is rapidly exterminating the native Shearwaters upon the islands, is an inhabitant also of Ulani. $P$. newelli is included by the Hon. Walter Rothschild, in his recent work, as a species on the verge of extinction (Extinct Birds, 1907, p. xii).

Mr. Ridgway examined the type-specimen, and considered it to be undoubtedly a new species. He observes:- "It comes nearest to $P$. auricularis, Townsend, of Clarion Island (Revillagigedo Group, north-west Mexico), but differs in the blacker colour of the upper-parts, the wholly white malar region, the more extensive, more uniform, and more abruptly white anterior and central under tail-coverts, more extensive and 'solid' blackish border to the under wing-covert region, and especially in the very abrupt line of demarcation along the sides of the neck, between the black 


\section{MONOGRAPH OF THE PETRELS.}

of the upper parts and the white of the under parts. $P$. auricularis has the bill entirely black and also stouter."

On comparing this description with the three specimens of $P$. auricularis in the Rothschild Collection, I find that the best character for the separation of $P$. newelli is apparently the white central under tail-coverts (these being black in $P$. auricularis), and the absence of mottling on the sides of the neck.

In a letter lately received from Mr. W. Alanson Bryan, he tells me that, while collecting in the mountains on Molokai in May and June, he found a poorly mounted example of $P$. newelli in a native cottage in Wailau Valley. The owner had captured it sitting in the grass near his house, and kept the skin as a curiosity. The birds nest in the high cliffs at an elevation of from 2000 to 4000 feet, in holes under the roots of trees, amongst the undergrowth and vines, and are so difficult to locate that they have to be searched for with specially trained dogs. Although Mr. Bryan went with a party of natives and dogs to the places where they had procured birds the year before, he was unsuccessful in finding a single specimen. The Mongoose having made its way into the island, the species is likely to be rapidly exterminated there.

I have not seen an example of $P$. newelli, and my description is therefore derived from Mr. Henshaw's article (l.c.). 


\section{PUFFINUS SUBALARIS, Ridgnay.}

\section{(RIDGWAY'S SHEARWATER.)}

Puffinus tenebrosus (nec Pelz.), Townsend, Pr. U. S. Nat. Mus., XIII., p. 142 (1890); id., Bull. Mus. C. Z. Harv., XXVII., p. 126 (1895).

Puffinus subalaris, Ridgway, Pr. U. S. Nat. Mus., XIX., p. 650 (1897, ex Townsend MSS.).

Puffinus obscurus (nec Gm.), Salvin, P. Z. S., 1883, p. 431.

Puffinus obscurus subalaris, Rothschild and Hartert, Nov. Zool., VI., p. 195 (1899).

Minor: ala 7.25-7.6 poll.: cauda brevi, 2.65-3.05 poll., rotundata: subtus albus : axillaribus, hypochondriis, et subcaudalibus albis, aut plus minusve fumoso-brunneis.

The Hon. Walter Rothschild and Dr. Hartert consider this species to be a form of $P$. obscurus, differing in the following points:-The flanks, which are pure white in the latter bird, are distinctly dusky in $P$. subalaris; the under wing-coverts resemble those of $P$. auduboni, and though without any defined band round the edge of the wing, there is a considerable amount of dusky-brown mottling. The lores are dark above, ashywhite below; the ear-coverts are dusky, bordered with white on their lower margin; the line between the white and the dusky-brown usually more sharply defined than in $P$. obscurus or in $P$. auduboni, but the dusky colour does not encroach on the white sides of the chest (Nov. Zool., VI., p. 195). The most obvious difference between $P$. subalaris and $P$. auduboni lies in the dusky clouding on the flanks, under wing-coverts and axillaries, as well as in the dark under tail-coverts in the former species. The above is a summary of the conclusions of the authors before mentioned, and coincides with Mr. Ridgway's description.

I have examined several specimens of $P$. subalaris in the British Museum and the Rothschild Collection, and find that it is a smaller bird than $P$. auricularis, with duskybrown axillaries, and is further distinguished by having no black freckling on the sides of the throat, but it is undoubtedly allied by reason of its dusky-brown under tail-coverts. $P$. subalaris differs from $P$. obscurus, and also from $P$. gavia, $P$. persicus, $P$. assimilis, etc., in its sooty-black under tail-coverts, and from $P$. auricularis principally in its dusky-brown axillaries and under wing-coverts, though these characters are found to be variable in a series. 


\section{MONOGRAPH OF THE PETRELS.}

This diagnosis appears to be correct when founded on the examples in the Rothschild Collection alone, but in the British Museum there are three specimens which require some consideration. Two were obtained in the Galapagos Islands by Captain Kellett and Lieutenant Wood, during the voyage of the "Pandora," but the exact locality has never been recorded. The third specimen, formerly in our collection, was presented by Admiral A. H. Markham, who obtained it on Charles Island, on the 18th of February (Salvin, P.Z.S., 1883, p. 431). These three specimens are almost similar, differing from the series in the Rothschild Collection in being lighter in colour beneath, with the axillaries either pure white, or only slightly mottled with brown. Salvin referred these birds to $P$. obscurus, but I believe them to represent a phase of plumage of $P$. subalaris : they are certainly not $P$. obscurus. If, therefore, I am correct in referring these forms, one with the axillaries smoky-brown, the other with the axillaries white, to the same species, there seems to be but one explanation, which is, that these differences in plumage are due either to age or season. The evidence tending to support this theory is as follows :-

February (Tower Island, Wenman Island [nestlings], Bindloe Island, Charles Island) :- Under wing-coverts white, clouded with dusky-grey; axillaries white (Markham specimen), or white mottled with dusky towards the tips.

March (Bindloe Island, Seymour Island) - Under wing-coverts white in one bird, rather less clouded with dusky-grey; but in a second specimen the under wing-coverts and axillaries are darker sooty-grey, with only a little white near the base.

July (Culpepper Island, Wenman Island):-Under wing-coverts nearly pure white; axillaries pure white. Some specimens, however, have a good deal of dusky mottling on these parts.

August (Jervis Island) :-Under wing-coverts and axillaries more dusky, but not entirely so.

November (Albemarle Island, Mus. Brit.):-Under wing-coverts and axillaries dusky throughout.

I have not been able to examine any specimens obtained between August and November; in the latter month, the colour of the under wing-coverts and axillaries is darkest, but it will be noticed that, when these are pure white, the birds have been procured in July, when the white on the under-wing reaches its maximum, and from thenceforward a gradual darkening takes place. In February, which is the breeding season, as proved by a downy nestling in the Rothschild Collection, the under wingcoverts and axillaries are again white, though clouded with dusky-grey.

The two examples procured by Kellett and Wood measure: Wing, 7.1-7.3 inches ; tarsus, 1.3-1.4; middle toe and claw, 1.4-1.5 ; culmen, 0.95-1.0. Admiral Markham's bird from Charles Island measures : Wing, 7.55 inches ; tarsus, 1.45 ; middle toe and claw, 1.6; culmen, 1.05. This specimen was sent to Washington for comparison with the types, and was pronounced by Dr. Ridgway to be identical with them. 


\section{PUFFINUS SUBALARIS.}

The other specimens in the British Museum from Tagus Cove, Albemarle Island, and from Jervis Island, have the following measurements :-

${ }^{7}$. Wing, 7.3-7.6 inches; tarsus, 1.35-1.45; middle toe and claw, 1.65-1.7; culmen, 1.1-1.2.

9. Wing, 7.6 inches ; tarsus, 1.45 ; middle toe and claw, 1.7 ; culmen, 1.1.

Three males in the Rothschild Collection from Bindloe Island, Tower Island, and Seymour Island, measure as follows: Wing, 7.25-7.6 inches; tarsus, 1.4-1.5; middle toe and claw, 1.6-1.65; culmen, 1.0-1.1.

No notes have been published on the habits of this species, but the Hon. Walter Rothschild and Dr. Hartert, in the memoir previously quoted, state that a great many eggs were collected on Culpepper Island during the last days of July. They were found singly in little holes under rocks, among seaweed. The birds were very tame, allowing themselves to be taken from the nest without resistance (Nov. Zool., VI., p. 195). The eggs are without gloss, but smooth : if held up to the light they appear almost pure white, or light green. They measure $54 \mathrm{~mm}$. by $35 \mathrm{~mm}$. (=2.2 inches by 1.4); 53.5 by $35(=2.15$ inches by 1.4$) ; 47$ by 34.5 (=1.9 inch by 1.35), etc. Specimens in the British Museum measure: Axis, 1.95-2.55 inches; diam., 1.35-1.4.

Adult female. General colour above sooty-black, the head being uniform with the back; wing-coverts like the back; quills and tail-feathers rather deeper black; the primary-coverts and quills with faintly indicated fringes of lighter brown at their ends; lores, sides of face and ear-coverts sooty-black like the crown; cheeks white, with a few dusky spots below the ear-coverts; under the eye a white spot; the line between the white cheeks and the black of the sides of the face fairly well defined, but slightly broken with blackish mottlings on the sides of the fore-neck and chest, the latter having a patch of sooty-black; entire under-surface of body pure white, excepting the flanks, thighs, and under tail-coverts, which are sooty-brown; axillaries also sooty-brown, with white fringes at the tips, and a little white at the extreme base; under wing-coverts entirely sooty-brown, the feathers slightly darker subterminally; quills dusky-black below, with a slight ashy shade along the inner webs; "bill black above, bluish slate-colour below ; feet bluish-white, the outer toe black; tarsi bluishwhite, blackish along the back, and on the lower portion of the outsides; iris light blue" (C. M. Harris). Total length about 12 inches ; culmen, 1.1 ; wing, 7.6 ; tail, 2.6 ; tarsus, 1.45 ; middle toe and claw, 1.7.

The sexes are alike in colour, and the measurements of both males and females are given above.

The description has been taken from a specimen in the British Museum. It was obtained by Mr. Beck at Tagus Cove, Albemarle Island, on the 29th of November, 1897, during the Webster-Harris expedition to the Galapagos. The species is so similar to $P$. auricularis that it has not been considered necessary to figure it. 


\section{PUFFINUS GAVIA (Forster).}

\section{(FORSTER'S SHEARWATER.)}

(Plate 32.)

Procellaria gavia, Forster, Descr. Anim., ed. Licht., 1844, p. 148 ; Gray, Ibis, 1862, p. 246.

Asstrelata gavia, Coues, Pr. Acad. Philad., 1866, pp. 154, 171.

Puffinus gavia, Hutton, Ibis, 1867, p. 189 ; Buller, Birds New Zeal., p. 318 (1873); 2nd ed., II., p. 236 (1888); Suppl. I., p. 99 (1905) ; Salvin, Cat. Birds Brit. Mus., XXV., p. 381 (1896).

Puffinus opisthomelas (nec Coues), Finsch, J. f. O., 1870, p. 371.

Fulmarus gavia, Gray, Handl. Birds, III., p. 107 (1871).

Puffinus gavius, Hutton, Ibis, 1874, p. 42.

Minor : cauda brevi, rotundata : ala 8.5-9.0 poll. : subtus albus : axillaribus fumosobrunneis: subcaudalibus albis, lateralibus apicem versus cinerascentibus.

THIS is one of the most distinct members of the small group to which it belongs. It has a wing of from 7.9-9.0 inches in length, and must therefore be referred to the section of $P$. obscurus.

$P$. gavia is to be recognised from the nearly allied species by its sooty-brown axillaries, and from $P$. persicus and $P$. subalaris, which it resembles in this respect, by its pure white under tail-coverts.

Forster's Shearwater was discovered in Queen Charlotte's Sound, New Zealand, during the voyages of Captain Cook, but was not described until 1844, nor was it figured in the celebrated series of "drawings" made during Captain Cook's voyages by George Forster. I have, however, little doubt that the species which is now known as $P$. gavia is that which Johann Reinhold Forster described in the notes which were edited and published by Professor Heinrich Lichtenstein in 1844.

It is an inhabitant of the New Zealand seas, where Sir Walter Buller records it as comparatively common, being frequently picked up dead, or in an exhausted condition, in the sea-drift on the open strand. In this way he procured many fine specimens on the northern shore of Cook's Strait; and the various local museums 


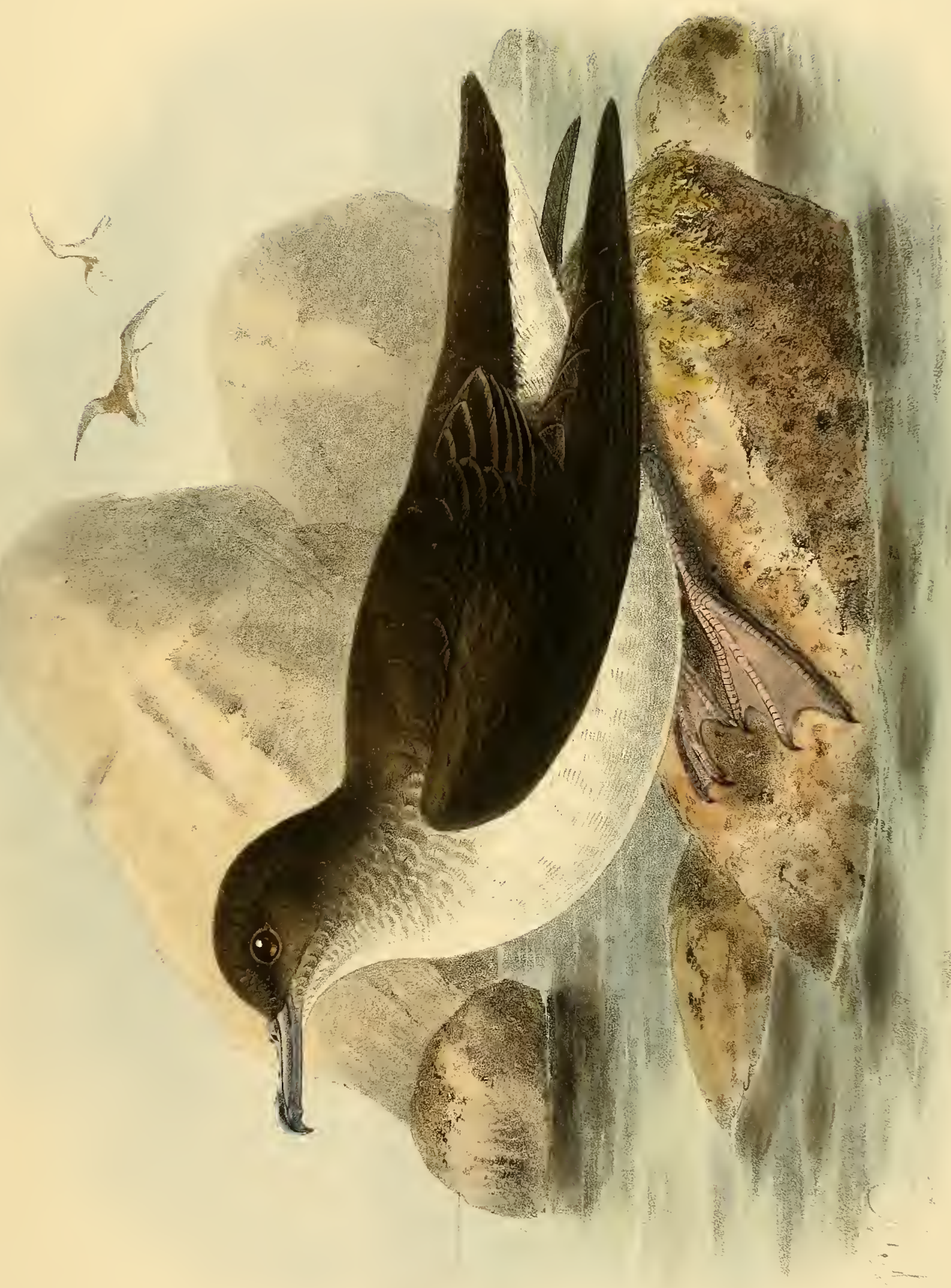




\section{PUFFINUS GAVIA.}

contain examples from other parts of the coast. Mr. Henry Travers met with this Shearwater on the Snares Islands, and the Rothschild Museum contains one of his specimens.

$P$. gavia is found in the Australian seas, for there is a specimen from Adelaide in the British Museum; and also one presented by Professor Anderson Stuart, which had been blown on shore during a storm, and was picked up in the Victoria Park at Sydney, N.S.W., on the 2nd of August, 1891, by Mr. F. J. Bourne (Salvin, P. Z. S., 1891, p. 627 ; id., Cat. Birds Brit. Mus., XXV., p. 381).

The species is recorded by G. R. Gray from New Caledonia (Cat. Birds Trop. Isl., p. 56, 1859), but I have found no authority for this statement.

Mr. Wiglesworth draws attention to the fact that Forster described a variety of his $P$. gavia from Tahiti (native name "Etāòwe"), and another from Raiatea ("Terā-ó"). "They appear," says Mr. Wiglesworth, "to be two distinct speciesthe latter perhaps $P$. obscurus (Gm.) - but the descriptions are insufficient for their identification" (Abhandl. K. Mus. Dresden, 1890-91, No. 6, p. 81, 1891).

Sir Walter Buller gives the following excellent account of the habits of this Shearwater :-

"They congregate in flocks, often of considerable size, and fly in a compact body, generally in a zigzag course, with a very rapid movement of the wings and not far above the water. Their flight is peculiar, too, in this respect, that they appear all to turn at the same moment, like a company of soldiers, showing first the dark plumage of the upper-surface and then the white under-parts, as they simultaneously dip towards the water.

"Their habits are sociable, and flocks may often be seen in the daytime disporting themselves in the sea, making short flights just above the surface, then flopping into the water, splashing and chasing one another in their playful gambols, and when tired of their fun, rising in a body and rapidly disappearing from view as already described. On one occasion I saw a flock of several hundreds thus amusing themselves in the broad sunshine (although the bird is more nocturnal than diurnal) as our ship was steaming through the narrow 'French Pass' in Cook's Strait.

"They seem to scatter at night, for as darkness approached I have noticed numerous single examples, as if the flocks of the daytime were dispersing over the surface of the ocean in quest of their food. They fly low but swiftly, and with a note resembling the native name by which the bird is called, but somewhat prolonged, as "paka-ha-apaka-ha-a.' During the breeding season I have seen very large flocks of them between Whale Island and the mainland, some of them hovering on the wing, hundreds together in 'schools,' or flocks, and others scattered far and wide over the surface, floating in a listless manner, as if resting after the hunting exploits of the night.

"Occasionally, perhaps once in several years, they appear in prodigious flocks, and seem to cover the sea for miles around; but they soon scatter again over 'Ocean's 


\section{MONOGRAPH OF THE PETRELS.}

boundless bosom,' and are then not more plentiful than the other Petrels. This periodical 'mustering of the clans' is doubtless due to a superabundance of some particular food-supply in the part of the sea where they congregate. Whale Island is one of their favourite breeding grounds, the places selected being the stony, scrubcovered slopes near the summit, as well as the holes and crevices among the rocks far above high-water mark. The adjacent little island of Motoki is also a nesting site. The island of Karewa, in the Bay of Plenty, and the numerous islands in the Hauraki Gulf are also favourite breeding grounds. They nest in communities, and their burrows are like rabbit warrens, covering acres in extent. As a rule they go down vertically for about a foot, and then spread off laterally for a distance of two feet or more, thus forming a chamber in which the Petrel deposits her single egg, and afterwards cradles her young. In the early morning the old birds go off to sea, and do not return to their nests till after dark, when there is a great noise and excitement among the nestlings in their eagerness for food which has been stewing for them all day long in their parents' crops.

"The Maoris state that the young birds quit their nests for the sea towards the end of February, which would accord with my observations on Whale Island. The natives do their best, however, to interfere with this domestic arrangement, for when the fledglings are about to take their departure, they are visited by Maori hunting parties, who capture sometimes four or five hundred of them in a day, and pot them in their own fat as huahua, which is esteemed a great delicacy. Having regard to the profit, the island is strictly tapu during the early part of the breeding season, and no native is allowed to land there. The expiration of the tapu and the slaughter of the innocents form one and the same event.

"It breeds on several of the large islands in the Hauraki Gulf ; and Mr. Cheeseman found it nesting on the 'Hen and Chickens.'

"An egg of this species in my son's collection is broadly oval, measuring 2.3 inches in length by 2.0 in breadth, and is perfectly white."

Adult male. General colour above sooty-black; wing-coverts like the back; quills and tail-feathers black; crown of head sooty-black, like the back; sides of head also sooty, with a little white mottling on the lores, and a white line above and below the eyes; throat and under-surface of body pure white; the cheeks, sides of throat and sides of neck dull ashy, mottled with white; over the thighs a patch of sooty-black; under tail-coverts pure white; under wing-coverts also pure white, with a narrow edging of black mottling round the wing; axillaries smoky-brown, with narrow white tips; quills dusky below, slightly more ashy along the inner webs; "bill dark grey, lighter and more yellowish-grey on the under mandible; tarsi and toes pinkish fleshcolour, stained with blackish-brown along the front of the tarsus, and on the outer edge of the toes; the webs darker ; iris brownish black" (Sir Walter Buller). Total length 13.5 inches ; culmen, 1.35 ; wing, 8.5 ; tail, 2.5 ; tarsus, 1.75 ; middle toe and claw, 1.9. 


\section{PUFFINUS GAVIA.}

Adult female. Similar to the male, but having the ashy-brown colour of the sides of the neck encroaching on the throat, and extending down the sides of the breast, the chin being white, but the centre of the throat mottled with ashy-brown; sides of the body smoky-brown, as also a patch over the thighs; under tail-coverts white, the lateral ones edged with smoky-brown along the outer webs; under wing-coverts white, with a broad band of light smoky-brown along the edge of the wing; axillaries smokybrown. Total length, 13.0 inches ; culmen, 1.4 ; wing, 9.0 ; tail, 2.7 ; tarsus, 1.7 ; middle toe and claw, 1.9.

According to Sir Walter Buller, the nestling is covered with very thick down, slatecoloured on the upper, and white on the under-surface. The young bird assumes the colours of the adult from the nest, but with rather paler margins to the wing-coverts, the woolly covering clinging longest to the back and flanks.

The description of the male is taken from a specimen procured in New Zealand by Sir Walter Buller, and the female is from the Snares Islands, obtained by Mr. Henry Travers. Both these specimens are in the Rothschild Collection.

The figure in the Plate I believe to have been drawn from the Hauraki Gulf specimen. 


\title{
41. PUFFINUS PERSICUS, Hume. \\ (PERSIAN SHEARWATER.)
}

\author{
(Plate 33.)
}

Puffinus sp., Heuglin, Ibis, 1859, p. 349.

Puffinus persicus, Hume, Stray F., I., p. 5 (1873), VIII., p. 115 (1879) ; Butler, Stray F., V., pp. 285, 292 (1877) ; Barnes, Ibis, 1893, p. 175 ; Salvin, Cat. Birds Brit. Mus., XXV., p. 381, Pl. IV. (1896) ; Yerbury, Ibis, 1896, p. 37 ; Blanf., Faun. Brit. Ind., Birds, IV., p. 356 (1898) ; Reichenow, Vög. Afrikas, I., p. 30 (1900).

Puffinus obscurus (nec Gm.), Blanf., Ibis, 1873, p. 215 ; id., Geol. and Zool. Persia, II., p. 295 (1876).

$P$. gavice similis, sed gutture pure albo, minime fusco marmorato, et hypochondriis late nigro striatis, distinguendus.

Thобян closely allied to Puffinus gavia, the Persian Shearwater is easily distinguished by its blacker upper-surface, and by the clearly defined line of the white on the sides of the throat, thus differing from $P$. gavia, in which the mottling sometimes extends across the throat. In $P$. persicus the under tail-coverts are white, with the long lateral feathers blackish; in $P$. gavia these are entirely white, or with only a little dusky edging to the long feathers. The axillaries of $P$. persicus are smoky-black, and slightly paler in those of $P$. gavia.

$P$. persicus can be at once separated from $P$. obscurus by the larger size of its bill. It was described by Mr. A. O. Hume from a female obtained at sea between Gwadar and Muscat on the 21st of February, 1872, and others were also observed on the Arabian coast. Colonel Butler found it abundant on the Mekran coast, where he obtained a female in 1877, and he also noticed the species 120 miles further up the Persian Gulf, while Lieutenant Barnes (l.c.) says that it is not uncommon near Aden. Blanford states that it is frequent on the coasts of Sind and Baluchistan, and in the Arabian Sea from Bombay to Aden (Faun. Brit. Ind., Birds, IV., p. 357). In 1859 the late Baror von Heuglin recorded a Shearwater, which was probably $P$. persicus, from off the coast of Somaliland. He says that it 


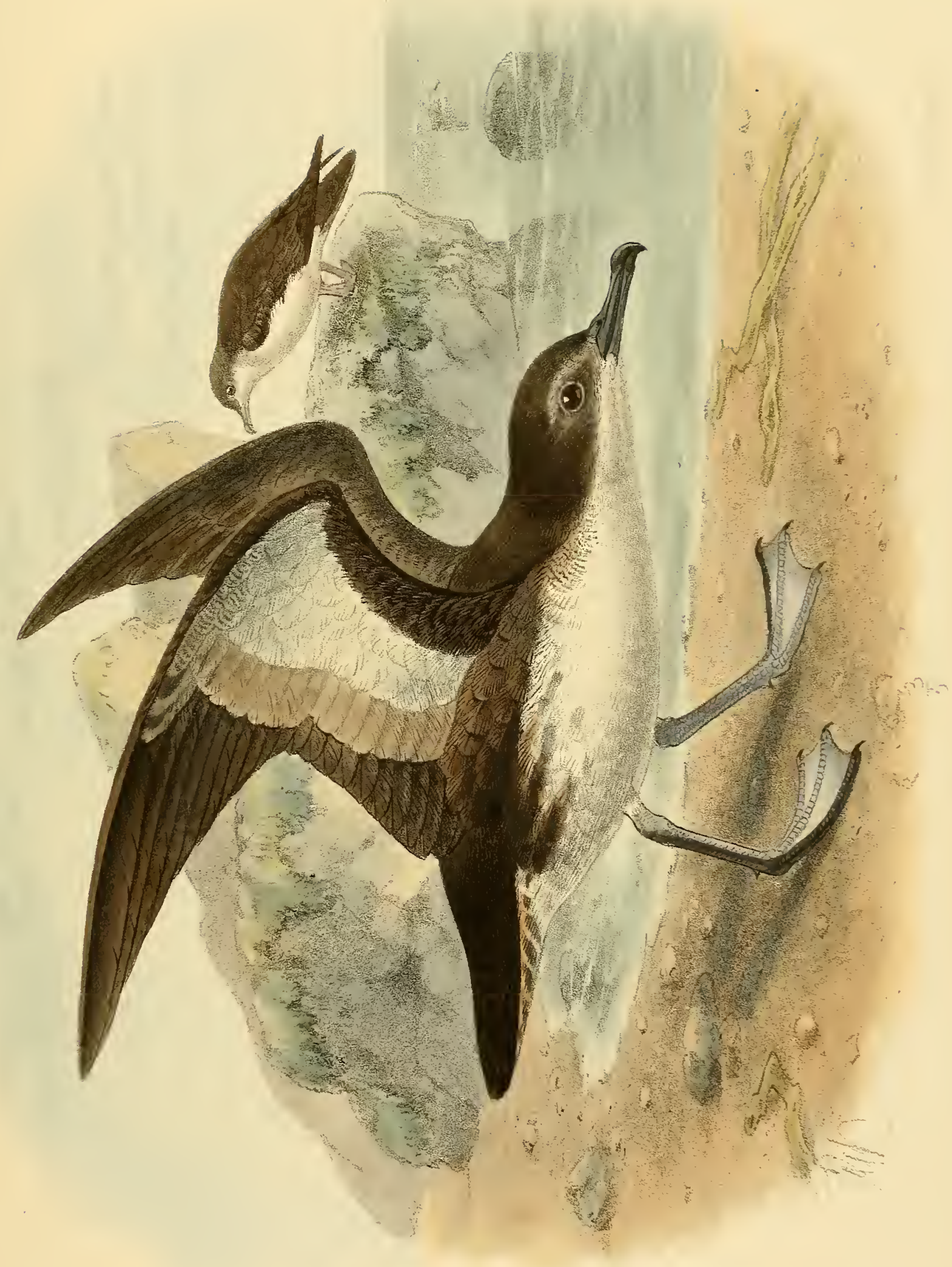





\section{PUFFINUS PERSICUS.}

was "dark above and light below, and of the size of a Turtle-dove" (Ibis, 1859, p. 349).

Colonel Butler says that it is common all along the Mekran coast, but is of a shy nature, and consequently difficult to procure. He never saw the species on the wing within shot of the boat, but occasionally, when resting on the water, the birds allowed the steamer to approach within range, and it was in this way that he shot the only specimen secured. Morning and evening they might be seen, always far out at sea, sailing along close to the water, skimming often over the waves with wings extended and motionless, and then continuing their wandering course for some distance with rapid strokes. They have a peculiar Plover-like habit, when flying, of turning from side to side, looking dark one second, and light the next, as they show their white breast and dark back alternately (Stray Feathers, V., p. 292).

Adult female (Type of species). General colour above sooty-black, including the wing-coverts, with indications of brown margins to the feathers; quills and tail black; head slightly browner than the back (worn plumage), including the upper lores and ear-coverts, the line of demarcation between the black upper-surface and the white under-surface rather sharply defined, with very little black mottling on the sides of the fore-neck; space between the gape and the eye white; upper and lower eyelids white; cheeks and entire under-surface of body pure white, including the central under tail-coverts; the longer central coverts and all the lateral ones sooty-black, with narrow white tips to the feathers; under wingcoverts white, thickly mottled with sooty-brown, especially round the edge of the wing; axillaries sooty-brown, with a small white tip, the lower ones white, mottled with brown; quills dusky brown below, ashy on the inner webs, and having a little white on the extreme base of the primaries; "bill dusky-brown, bluish at base, and on the basal three-fourths of the lower mandible ; legs and feet white, tinged with pink and lavender, with the claws, margin of the web, exterior of feet and outer toe, and part of ridge of middle toe, black" (A. O. Hume). Total length 12.5 inches; culmen, 1.3 ; wing, 7.3 ; tail, 2.9 ; tarsus, 1.5 ; middle toe and claw, 1.7 .

Colonel Butler states that his specimen, procured on the Mekran coast, had the bill and legs coloured as follows :- " Bill pale lavender, dusky at tip and on the upper mandible; legs white, with an opalescent gloss ; the lower part of the tarsus and outer toe blackish; outer side of middle toe and under side of all the toes dusky-black; iris dark brown."

A bird procured by Lieutenant Barnes off the Aden coast had the "bill plumbeous black; legs and toes pearly or opalescent white; claws and webs between the toes black."

The specimen described and figured is the typical example in the Hume Collection. 


\section{PUFFINUS OBSCURUS (Gm.).}

\section{(DUSKY SHEARWATER.)}

(Plate 34.)

Dusky Petrel, Lath., Gen. Syn., III., pt. 2, p. 416 (1785).

Procellaria obscura, Gm., Syst. Nat., I., p. 559 (1788).

Puffinus baroli, * Temm., fide Bonellii in Mus. Taurin (1820); Bp., Consp. Av., II., p. 204

(1856); id., Comptes Rend., XLII., p. 769 (1856) ; Salvad., Faun. d'Ital., Ucc., pp. 299, 300 (1872); id., Ibis, 1899, p. 541.

Puffinus obscurus, Steph. in Shaw's Gen. Zool., XIII., p. 230 (1826); Salvin, Cat.

Birds Brit. Mus., XXV., p. 382 (1896).

Nectris obscura, Keys. and Blas., Wirb. Eur., pp. xciv., 239 (1840).

Puffinus dichrous, Finsch and Hartl., Faun. Central Polyn., p. 244 (1867).

Puffinus opisthomelas var. minor, Hartl., P. Z. S., 1867, p. 832.

Puffinus opisthomelas (nec Coues); Finsch and Hartl., P. Z. S., 1868, pp. 9, 118.

Puffinus obscurus obscurus, Rothsch. and Hartert, Nov. Zool., VI., p. 194 (1899).

Minor : ala 6.5-8.1 poll. : subcaudalibus albis, lateralibus fumoso-brunneis : axillaribus albis : primariis intus fuscescentibus, minime albis.

THE range of this species extends from the islands of the Pacific Ocean to the Mascarene Islands. I have been unable to find any distinguishing characters between specimens from Samoa and the Pelew Islands, and those from the Seychelles and Réunion. It is possible that the colour of the bill and feet in the birds from these distant localities may prove different, but there is at present no evidence to this effect.

$P$. obscurus is one of the smaller Shearwaters, having a wing less tlian 9 inches in length. The under tail-coverts are sometimes pure white, with only the lateral ones blackish (e.g., examples from Réunion, Aneiteum, New Zealand); but they are generally dusky-black, with the central patch of coverts white, or white, more or less shaded with dusky-black. The colour of the under tail-coverts resembles that of $P$. gavia and $P$. persicus, but from these two species $P$. obscurus is distinguished by its white axillaries.

The type of Latham's "Dusky Petrel" was in the British Museum in $1785 . \mathrm{He}$

* Count Salvadori has recently informed me that $P$. baroli, Temm., is a synonym of the present species and not of $P$. yelkouanus, to which I had united it (vide supra, p. 107). 


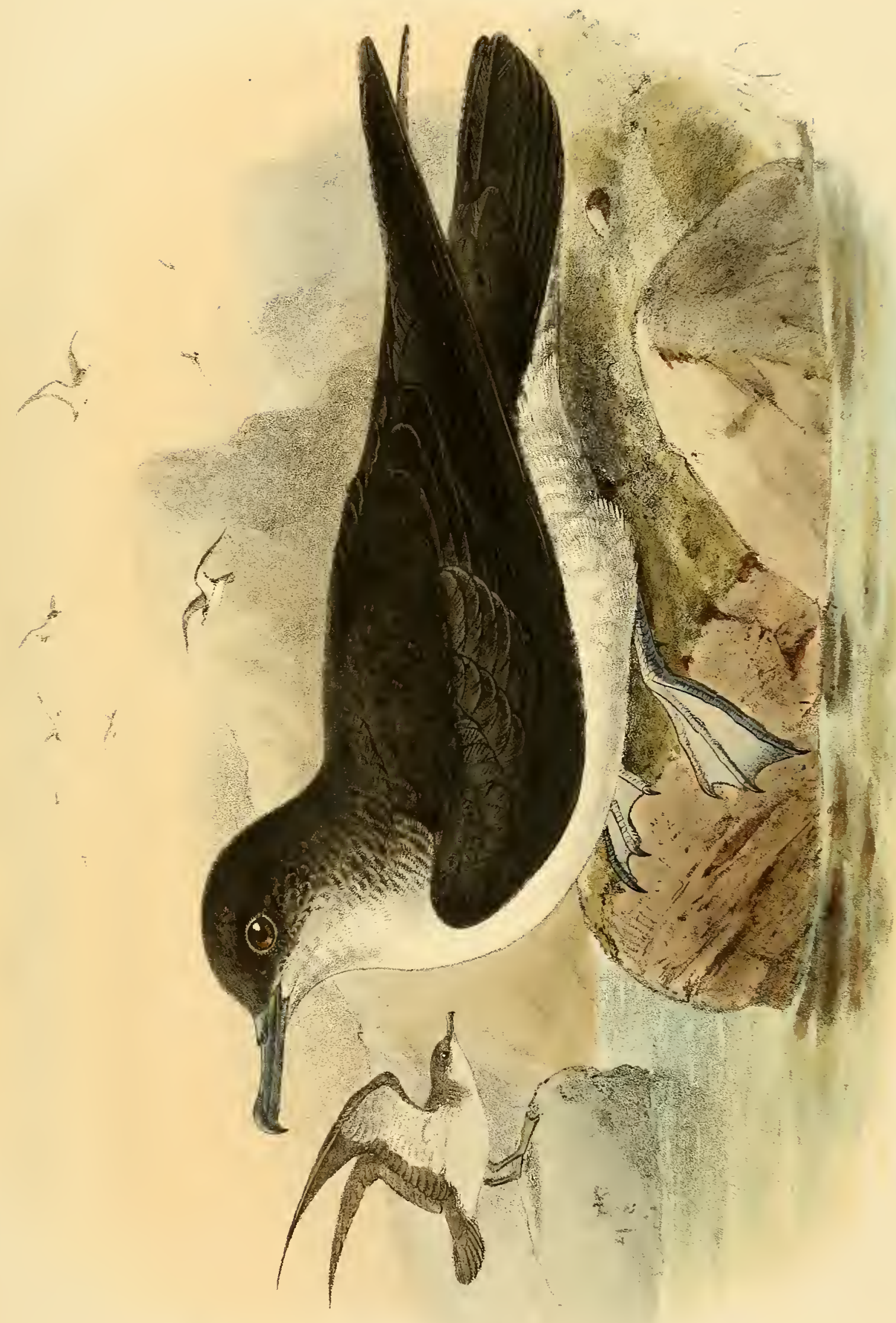





\section{PUFFINUS OBSCURUS.}

described it as follows:- "Length 13 inches. Bill, $1 \frac{1}{2}$; the sides of it horn-colour, otherwise black; in the usual place of the tube are only two small holes, serving for nostrils. The point of the bill hooked; the upper-parts of the body are dusky-black, the under, white; on the sides of the neck, brown and white mixed; the edges of the middle wing-coverts are whitish ; the legs for the most part black, except the inside, which is pale the whole length; and the two inner toes yellowish; the webs orangecolour ; claws black" (Gen. Syn., III., pt. 2, p. 416).

The type was from Christmas Island, and was doubtless one of the birds obtained during Cook's voyages, but it has now perished, like the rest of these imperfectly preserved specimens.

The so-called "Dusky" Shearwater is by no means the most dusky species of the genus Puffinus, many others having a better claim to the title. Wiglesworth, in his "Aves Polynesiæ" (Abhandl. K. Mus. Dresden, No. 6, 1890-91, No. 6, p. 80, 1891) gives the range of $P$. obscurus in the Pacific Ocean as follows:-Probably throughout Polynesia. Christmas Island (Latham); Phonix Islands, McKean Island (Graeffe); Samoan Islands, Manua Island (Powell); Ninafou (Hübner); Gilbert Islands (Finsch); Caroline Islands, Ruk, Ponapé (Kubary); Pelew Islands (Tetens ; Kubary).

I have examined specimens from the following localities in the British Museum: Tau Island, Samoa (Mrs. T. B. Cusack-Smith; Salvin, Cat. Birds Brit. Mus., XXV., p. 384); Manua Island, Samoa Archipelago (Rev. T. Powell ; Salvin, l.c.); Pelew Islands (Cohen; Salvin, l.c.); Aneiteum, New Hebrides (J. Macgillivray; Salvin, l.c.).

This series gives the following measurements :-

$\begin{array}{lcccccc} & & & \text { Wing. } & \text { Culmen. } & \text { Tarsus. } & \begin{array}{c}\text { Middle toe } \\ \text { and claw. }\end{array} \\ \text { Samoa Islands } & \ldots & \ldots & 7.8-8.1 & 1.1 & 1.55-1.6 & 1.7-1.8 \\ \text { Pelew Islands } & \ldots & \ldots & 7.3-8.0 & 1.0-1.1 & 1.45-1.5 & 1.65-1.85 \\ \text { Aneiteum } \ldots & \ldots & \ldots & 7.7 & 1.2 & 1.6 & 1.8\end{array}$

In all these examples the quill-lining is dusky, never white, but the inner web is generally a little lighter than the outer, and somewhat more ashy-brown, though not so pale as in $P$. bailloni; the axillaries are pure white; the under tail-coverts are sootyblack, generally with a white apical margin, the lateral coverts sometimes particoloured, externally sooty-black, internally white, where they adjoin the central bunch of pure white under tail-coverts.

The specimen from "New Zealand" (Salvin, Cat. Birds Brit. Mus., XXV., p. 384), purchased from Mr. Whitely, of Woolwich, measures: Wing, 8.2 inches ; culmen, 1.2; tarsus, 1.65 ; middle toe and claw, 1.8. The axillaries are pure white, and the under tail-coverts white, with a slight grey mottling, the lateral ones sooty-black, more or less white on the inner web.

Sir Walter Buller, in spite of his long residence in New Zealand, was unable to confirm its existence there.

In the British Museum are examples of this Shearwater from Réunion and from 


\section{MONOGRAPH OF THE PETRELS.}

the Seychelles, which have the same dark inner web to the primaries as those of the Pacific Ocean. In all of them the quill-lining is dark ashy-brown. In the Seychelles birds the axillaries are white, but in the females they are slightly mottled with brown at the tips. The under tail-coverts are white, also mottled with brown towards the ends, the lateral ones black with narrow white tips.

In addition to the above specimens the Hon. Walter Rothschild has lent me his series of $P$. obscurus, which measure :-

\begin{tabular}{|c|c|c|c|c|c|c|c|c|}
\hline & & & & & Wing. & Culmen. & Tarsus. & $\begin{array}{l}\text { Middle toe } \\
\text { and claw. }\end{array}$ \\
\hline$\sigma$ & Pelew Islands (Kubary & & $\ldots$ & $\ldots$ & 7.7 & 1.0 & 1.5 & 1.5 \\
\hline$q$ & do. do. & & . & . & 8.0 & 1.0 & 1.6 & 1.6 \\
\hline$t^{*}$ & Ruk Island, Carolines & . & .. & . & 8.0 & 1.05 & 1.5 & 1.7 \\
\hline 7 & Do. & . & . & . & 8.0 & 1.1 & 1.5 & 1.7 \\
\hline t & Seychelles (Thibault) & . & . & . & 7.7 & 1.0 & 1.5 & 1.65 \\
\hline$q$ & Praslin, Seychelles & . & . & . & 7.6 & 1.05 & 1.5 & 1.6 \\
\hline & Do. & . & .. & .. & 7.65 & 1.1 & 1.55 & 1.5 \\
\hline & Do. & .. & . & . & 7.5 & 1.05 & 1.4 & 1.45 \\
\hline & Isle Cousin (Thibault) & . & . & $\ldots$ & 7.4 & 0.9 & 1.5 & 1.5 \\
\hline
\end{tabular}

The birds from the Pelew Islands and the male from Ruk Island have the axillaries white, but the female from the latter locality has white axillaries with a shade of smoky-brown at the ends.

Of the habits of $P$. obscurus nothing appears to have been recorded, but they are doubtlcss similar to those of $P$. bailloni and other allied species.

Adult female. General colour above sooty-brown, the wing-coverts like the back ; quills and tail-feathers darker and more sooty-black; head sooty-brown like the back, as also the ear-coverts; lores slightly mottled with white; upper and lower eyelid white ; cheeks and under-surface of body, white ; the sides of the lower throat and foreneck dusky-brown, this colour extending to the sides of the upper breast, the feathers edged with white where they adjoin the white neck and breast, thus producing a broken and mottled line; a patch of sooty-black above the thighs; under tail-coverts sooty-brown, the shorter central coverts white, some of the outer ones more or less brown externally ; under wing-coverts white, with a broad band of sooty-brown feathers round the margin of the wing beneath; axillaries white; quills dusky-brown below, the inner webs rather darker. Total length about 11.5 inches; culmen, 1.0 ; wing, 8.0 ; tail, 3.1 ; tarsus, 1.6 ; middle toe and claw, 1.6.

Adult male. Similar to the female. Total length about 11.5 inches; culmen, 1.1 ; wings, 7.65 ; tail, 3.1 ; tarsus, 1.55 ; middle toe and claw, 1.5.

The female described is in the Rothschild Museum, and was obtained by Dr. Kubary in the Pelew Islands; the male is from Praslin, in the Seychelles. The figure in the Plate is drawn from the Manua specimen in our collection. 


\section{PUFFINUS AUDUBONI, Finsch.}

\section{(AUDUBON'S SHEARWATER.)}

Cahow, Smith, Hist. Virginia (1629).

Puffinus obscurus (nec Gm.), Jones, Nat. Hist. Bermuda, pp. 55, 93 (1859).

Puffinus auduboni, Finsch, P. Z. S., 1872, p. 111 ; Baird, Brewer and Ridgway, Water

Birds N. Amer., II., p. 386 (1884) ; A. O. U. Checklist, 2nd ed., p. 32 (1895);

Feilden, Ibis, 1889, pp. 69, 503 ; Lawr., Auk, 1889, p. 19.

Puffinus obscurus, pt., Salvin, Cat. Birds Brit. Mus., XXV., p. 382 (1896).

Puffinus l'herminieri, Lesson; Riley, Auk, 1902, p. 195; A. W. Clark, Pr. Bost.

Soc. Nat. Hist., XXXII., p. 229 (1905).

$P$. obscuro simillimus, sed forsan brunnescentior: axillaribus albis, interdum fuscescenti-nigro subterminaliter notatis: pedibus nigricantibus.

ALtнобGH it has been suggested by Mr. H. G. Riley (Auk, 1902, p. 195) that this species should bear the name of $P$. l'herminieri of Lesson, I think the following diagnosis (Rev. Zool., 1839, p. 102 :-Corpore supra nigro, infrà albo, rostro et pedibus nigris. Long. 12 poll. Habitat, ad ripas Antillarum)-too general in character to determine the exact species indicated. It will, therefore, be better to adopt Dr. Finsch's name of $P$. auduboni, which is properly described and characterised, rather than one which must always remain open to doubt.

$P$. auduboni so much resembles $P$. obscurus that some of the American specimens are scarcely to be distinguished from it, and I separate the two with great hesitation. The characters given by the Hon. Walter Rothschild and Dr. Hartert are : the white under tail-coverts, the paler sides of the chest, the white axillaries, and the white under wing-coverts, which have a less distinct marginal band in $P$. auduboni than in P. obscurus. My own observation, however, leads me to the conclusion that in $P$. auduboni we find the same variation in the under tail-coverts, from pure white to blackish-brown, as in P.obscurus. The difference may be sexual, or due to age or season, but no specific differences can be founded on these characters. Nor can the white axillaries be relied upon to distinguish the two species, for in $P$. obscurus also the axillaries are either pure white, or white with a dusky-grey tip. The marginal band on 


\section{MONOGRAPH OF THE PETRELS.}

the wing, however, is broader and blacker in $P$. obscurus, being narrower, browner, and more broken up in $P$. auduboni. In the "Biologia Centrali-Americana" (Aves, III., p. 436) it is stated that $P$. auduboni is rather smaller than $P$. obscurus, but this now appears to be doubtful. Five specimens of $P$. auduboni measure as follows: Wing, 7.7-8.0 inches; culmen, 1.1-1.2; tarsus, 1.55-1.6; middle toe and claw, 1.55-1.95.

In $P$. obscurus from the Pacific Islands, the measurements are as follows: Wing, 7.3-8.1 inches ; culmen, 1.0-1.2 ; tarsus, 1.45-1.6 ; middle toe and claw, 1.65-1.85.

The measurements of these two forms afford no characters for specific separation, though $P$. auduboni would appear to have a slightly longer tarsus than $P$. obscurus. I find that the chief difference between the eastern and western birds lies in the browner colour of $P$. auduboni, which is never so black as $P$. obscurus. The patch above the thighs is brown in the former bird, not black, and the band round the edge of the wing below is browner, and less distinct than in P. obscurus.

The specimen from Montserrat in the British Museum, collected by Mr. Sturge (P. Z. S., 1879, p. 765), is blacker than the ordinary specimens of $P$. auduboni, and closely resembles $P$. obscurus.

Audubon's Shearwater is a species of Eastern North America. The A. O. U. "Checklist" gives the range as from the warmer parts of the Atlantic, incidentally northwards to New Jersey and Long Island. It breeds on the Bermudas and Bahamas (Andros Island), San Domingo, Montserrat, and other West Indian islands, as far south as the island of Grenada.

Mr. J. M. Jones in his "Naturalist in Bermuda" (1859), gives an interesting account of the species, which, in 1849, bred on "Black," or "Gurnet-head " Rock, where eggs and young were taken by Captain Orde and Captain McLeod (t.c., p. 55). Dr. Percy Lowe, who accompanied Sir Frederick Johnstone on his yacht, the R.Y.S. "Zenaida," to the Bermudas, in May, 1907, procured a female of $P$. auduboni with its egg, and was informed that this was the first occasion of its nesting on the islands for many years, though it did so formerly in large numbers.

Audubon states that on the 26th of June, 1826, when becalmed in the Gulf of Mexico, off the western coast of Florida, he found the species numerous. In the West Indies it has been procured off the island of San Domingo by Dr. Bryant, and Mr. C. B. Cory says that, though he did not himself observe P. auduboni in that island, he saw a number at sea about twenty miles to the north of Tortuga Island.

Dr. J. G. Wells relates $(A u k, 1889$, p. 19$)$, in a letter to Mr. G. N. Lawrence, that young birds of a "Diablotin" had been brought to the market at Greenville, Grenada Island, for sale : the natives stating that they had been captured in holes on a small island to the eastward called "Mouchoir Quarré." He himself afterwards visited a small islet called Labaye Rock, about a mile off the Port of Greenville, on the 2nd of April, 1888, and procured adult birds, nestlings, and an egg. He says that it is 


\section{PUFFINUS AUDUBONI.}

common in the Grenadines, and nests on most of the small islands about Carriacou, especially on Bonaparte Rocks.

Mr. A. Hyatt Verrill records the species as a rare resident in the island of Dominica, breeding at Scott's Head and Bois d'Inde. It is not uncommon on the fishinggrounds in the Martinique Channel, where the fishermen stated that the birds were very bold, often attempting to rob the fish from their canoes.

Audubon's Shearwater frequents the open sea during the daytime, and, according to Mr. C. B. Cory, who met with the species in the Bahamas, it is difficult to procure. The birds are very shy during the day, remaining far away from the land, and only returning late in the evening when it is too dark to distinguish them. All night long their mournful cries can be heard, but long before dawn they start again for the sea, where they may be seen in large flocks, resting on the open water, but always wary, if approached by any vessel. Dr. Bryant, in his notes on the birds of the Bahamas, says that he saw, about half-way from Andros to the Bank, a flock of Boobies, Sooty Terns, Noddies, Cabot's Tern, and Dusky Petrels, all fishing in company, and covering an area of at least a square mile, and in immense numbers. He states that the nest, consisting of a few dry twigs, was placed either in a hole or under a projecting portion of a rock, seldom more than a foot from the surface, and always within reach of the hand. On being caught, the birds made no noise, and offered no resistance, unlike the Tropic Bird, which fought manfully, biting and screaming with all its might.

The single egg, according to the same observer, was very fragile and highly polished, and varied considerably in size and shape, some being rounded, others elongate.

Mr. Bonhote never saw the birds outside their holes, nor could he distinguish the cries at night from those of the Sooty Terns. He found that incubation was carried on by both sexes, and before the egg is laid both birds occupy the same hole. The parent does not apparently brood the young, but merely sits beside it during the first day or two of its existence, after which it is left alone during the daytime (Ibis, 1903, p. 315).

The food of $P$. auduboni is said to consist of small fish, and the mandibles of squids and small cuttle-fish.

Mr. Hurdis, in an Appendix to Mr. Jones' "Naturalist in Bermuda" (1859, pp. 93-96), gives a note on the "Cahow," a bird mentioned by Governor John Smith, in his "General History of Virginia," published in 1629, and again by Purchas in 1738; and Mr. Hurdis proves conclusively that this must have been the bird we now know as $P$. auduboni. He found that it was still known to the natives under the name of "Cahow" in 1847, and subsequent observations have proved that it was undoubtedly Audubon's Shearwater.

Mr. A. E. Verrill, in a résumé of the history of the "Cahow," considers it to be extinct, and says that it was certainly not a Shearwater (Ann. and Mag. Nat. Hist. (7), IX., pp. 26-31). To this statement Canon Tristram demurs (Ibis, 1902, p. 525), affirming 


\section{MONOGRAPH OF THE PETRELS.}

that the bird he had known in the Bermudas, and there called the "Cahow," by the fishermen, was the same as that described by the older writers, and was undoubtedly a Shearwater.

Adult male. General colour above sooty-brown, the wing-coverts like the back; primary-coverts and quills a little darker than the back, but shaded with sootybrown, the inner webs of the quills being much paler brown; tail-feathers blackishbrown; head sooty-brown like the back, including the upper half of the lores; lower half of the lores and sides of face white, as also the upper and lower eyelids; earcoverts dusky-brown, mottled with streaks of white, with an indistinct line of white behind the eye, extending above the ear-coverts; cheeks and under-surface of body pure white, the upper breast with a patch of ashy-brown on each side; an irregular mottling of ashy or dusky-brown feathers along the sides of the neck, where the white under-surface joins the brown colour of the upper-surface; on each side of the lower flanks, above the thighs, a patch of sooty-brown feathers; under tail-coverts sootybrown, the central coverts white, with the outer webs sooty-brown, or freckled with the latter colour; under wing-coverts and axillaries white; the lateral coverts round the edge of the wing mottled with light brown, broken up on the carpal bend of the wing, and not forming a distinct band; quills dusky-brown below, lighter and more ashybrown on the inner web; " bill lead-colour (Cory), dull horn-colour, the mandible paler (P. R. Lowe); inner surface of tarsus opalescent, as also the webs and middle and inner toe" (P. R. Lowe). Total length about 12 inches ; culmen, 1.15 ; wing, 7.9 ; tail, 3.4 ; tarsus, 1.6 ; middle toe and claw, 1.8 .

Adult female. Similar to the male. Total length about 12 inches; culmen, 1.1 ; wing, 8.0 ; tail, 3.3 ; tarsus, 1.65 ; middle toe and claw, 1.9 .

The descriptions of the male and female are taken from specimens obtained by Mr. C. J. Maynard on Andros Island in the Bahamas; the male at Washerwoman Key on the 7th of May, and the female at Green Key on the 2lst of April. Both are in the Gerritt Miller Collection in the British Museum. The close resemblance of the species to $P$. obscurus renders a figure unnecessary. 



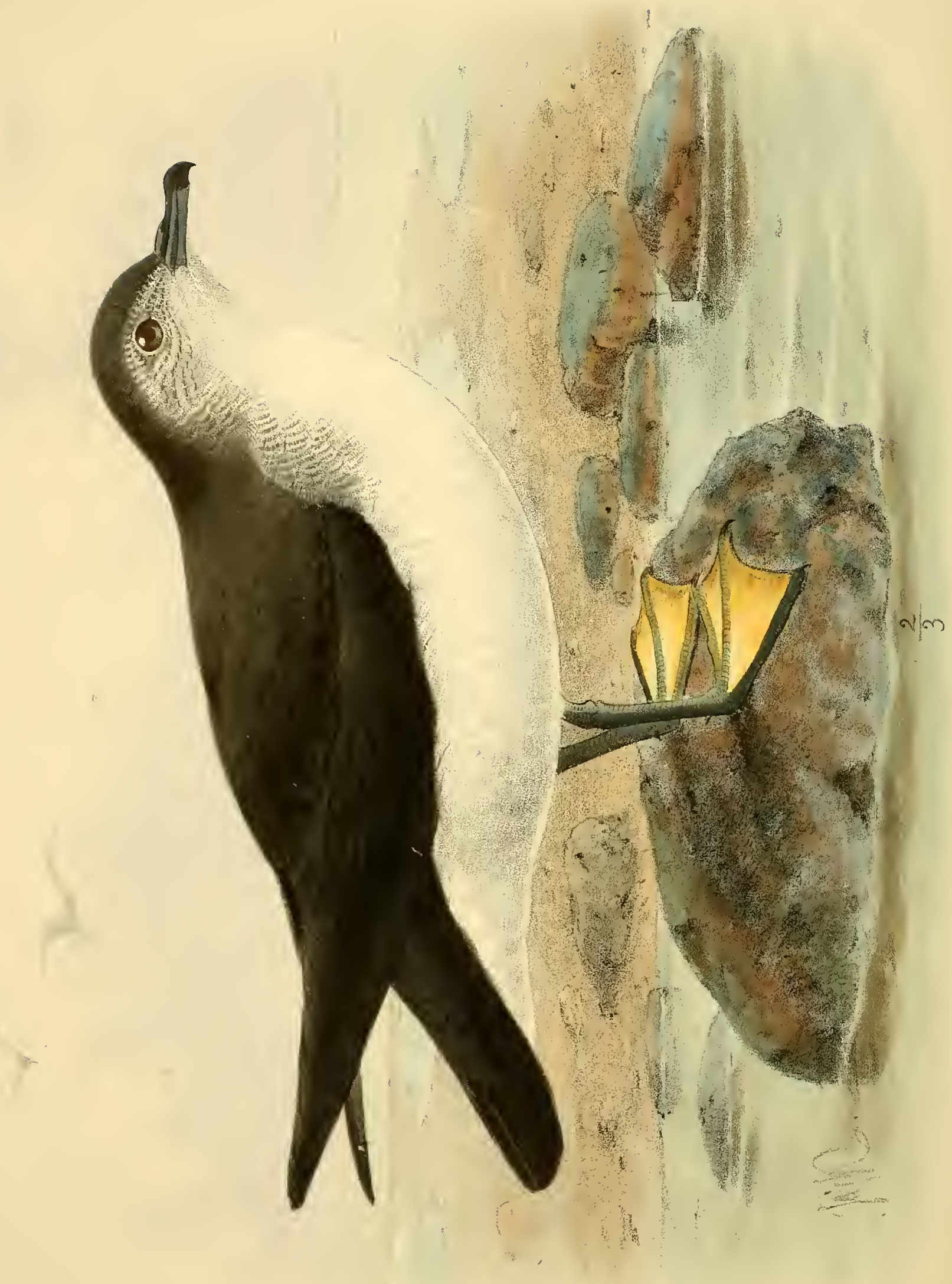

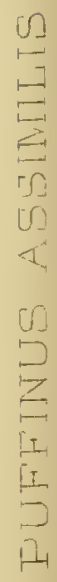




\section{PUEFINUS ASSIMILIS, Gould.}

\section{(GOULD'S SHEARWATER.)}

(Plate 35.)

Puffinus assimilis, Gould, P. Z. S., 1837, p. 156 ; id., Birds Austr., fol. VII., P1. 59 (1848) ; Coues, Pr. Acad. Philad., 1866, p. 192; Buller, Birds New Zeal., 2nd ed., II., p. 237 (1888) ; id., Suppl., I., p. 100 (1905) ; Wiglesw., Abhandl. K. Zool. Mus. Dresden, VI., 1890-91, No. 6, p. 80 (1891) ; Salvin, Cat. Birds Brit. Mus., XXV., p. 384 (1896).

Puffinus nugax, Solander, MSS.; Bp., Consp. Av., II., p. 205 (1856); Coues, Pr. Acad. Philad., 1864, pp. 141, 144 ; Gould, Handb. Birds Austr., II., p. 458 (1865); Finsch and Hartl., Faun. Central Polyn., pp. 242, 280, Taf. 3, fig. 5 (1867).

Procellaria nugax, Schlegel, Mus. Pays-Bas, VI., Procell., p. 31 (1863).

Puffinus obscurus (nec Gm.), Finsch, J. f. O., 1870, p. 370.

Puffinus sp., Hartl. and Finsch, P. Z. S., 1872, p. 112 ; Finsch, J. Mus. Godeffr., VIII., p. 45 (1875).

P. obscuro similis, sed ala subtus albidiore: subalaribus pure albis: remigibus intus quoque pure albis.

Puffinus assimilis is distinguished from the P. obscurus group of small Shearwaters by its pure white under wing-coverts, quill-lining, and under tail-coverts. It is an inhabitant of the Australian seas, extending to the South Atlantic Ocean. Gould originally described it from New South Wales, but in his "Handbook" mentions that all the specimens he had seen were from Norfolk Island, where it has since been found breeding by Dr. Metcalf (North, Nests and Eggs of Austr. Birds, p. 377, 1889). Mr. Robert Hall found $P$. assimilis nesting on the Pelsart Group of Houtman's Abrolhos, and procured eggs in July. Sir Walter Buller and Captain Hutton record the bird from the Hauraki Gulf, in New Zealand, but the latter says that south of Auckland it is replaced by $P$. gavia. Other breeding places are on the Kermadec Islands, where the birds are said to be smaller than those from New Zealand. Dr. Pirie (Eagle Clarke, Ibis, 1905, p. 261) captured two specimens on Gough Island, where it was found nesting by the 


\section{MONOGRAPH OF THE PETRELS.}

Scottish Antarctic Expedition, and it was doubtless $P$. assimilis which was observed by Mr. M. J. Nicoll during the voyage of the "Valhalla" between St. Paul's Rocks and Tristan da Cunha (Ibis, 1906, p. 674). It is said to occur on some of the North Atlantic Islands, such as Deserta Grande, but I cannot but think that the bird referred to is $P$. bailloni.

Sir Walter Buller mentions that, in December, 1888, Mr. Reishek discovered adult birds of $P$. assimilis on Chicken Island, occupying the same burrow as the Tuatara Lizard (Sphenodon punctatum). They were plentiful on the south-eastern side of the island, but less so on the smaller islands in the vicinity. During the breeding season, which commences in October, the male habitually goes to sea during the day, returning to the burrows at night, and its habits resemble those of other species of Shearwaters. Like Majaqueus parkinsoni and Estrelata cooki, P. assimilis goes somewhat further inland to nest than $P$. gavia, usually selecting the woody parts of the island and a high elevation, where it may be seen sitting on the trees in the moonlight uttering its cry, "ha-kwa-kwa."

The egg of this Shearwater is ovoido-conical in form, measuring 2.2 inches in length, by 1.4 inch in breadth, and when fresh is perfectly white (Buller, Birds N. Zeal., 2nd ed., II., p. 237, 1888) ; those from Raoul Island and Auckland, N. Z., in the British Museum measure : Axis, 1.95-2.0 inches ; diam., 1.4-1.45.

Adult male. General colour above slaty-black, deeper black on the scapulars and wing-coverts; quills black, with a shade of slaty-grey extending over nearly the whole of the outer web; tail-feathers black; head black, like the back; upper part of lores black, but the lower part sharply divided and white, like the sides of the face and cheeks; upper and lower eyelid white; ear-coverts white, with a narrow line of black along the upper margin, above which is a broad but ill-defined band of white, extending from above the eye and mottled with black streaks; entire under-surface of body pure white, including the sides of the neck, which are separated from the black upper-surface by some mottled feathers, which are white, with a sub-terminal black spot or bar; under tail-coverts pure white, with no dusky margins to the lateral coverts; under wing-coverts, axillaries and quill-lining all pure white, the quills being ashy-brown below, with the inner webs of the primaries entirely white; "bill dark horn-colour; tarsi and toes greenish yellow, webs yellowish orange" (J. Gould). Total length about 10.5 inches; culmen, 0.95 ; wing, 7.15 ; tail, 2.6 ; tarsus, 1.55 ; middle toe and claw, 1.7.

Adult female. Similar to the male. Total length about 10.5 inches; culmen, 1.0 ; wing, 7.2 ; tail, 2.7 ; tarsus, 1.55 ; middle toe and claw, 1.7.

The colours of the bill and feet have been given by other observers as follows :Hauraki Gulf (Buller):-Bill bluish-black; feet greenish-grey, with yellow interdigital webs, marked with black on the outer edge.

Gough Island (Scotia Exped.) :-Basal half of bill blue, distal part and nasal 


\section{PUFFINUS ASSIMILIS.}

tubes black; front of tarsus and toes greyish-blue; posterior portion of tarsus and sides of toes black; webs yellowish.

The latter specimen seems to have differently-coloured soft-parts from the Australian and New Zealand birds.

The description of the male has been taken from an example in the Rothschild Collection; it was procured by Mr. H. H. Travers on Herald Islet. The female is from the Kermadec Islands, and was formerly in Sir Walter Buller's Collection, but is now in the Rothschild Museum. I have been unable to find the specimen figured by Salvin. 


\title{
45. PUFFINUS ELEGANS, Gigl, and Salvad.
}

\author{
(GIGLIOLI'S SHEARWATER.)
}

(Plate 36.)

Puffinus elegans, Gigl. and Salvad., Atti Soc. Ital. Sc. Nat., XI., p. 457 (1868); iid., Ibis, 1869, p. 68 ; Gigl., Faun. Vertebr. Oceano, p. 32 (1870) ; id., Viagg. "Magenta," pp. 98, 103 (1875) ; Salvin, in Rowley's Orn. Misc., I., p. 256, Pl. 34 (1876); Ridgw., Man. N. Amer. Birds, p. 61 (1887) ; Salvin, Cat. Birds Brit. Mus., XXV., p. 385 (1896).

Puffinus sp. nov., Gigl. and Salvad., Ibis, 1869, p. 67.

$P$. assimili affinis, sed supra cinereo-plumbeus, plumis totis angustissime albo limbatis: tectricibus alarum mediis majoribus que et secundariis albo limbatis: subalaribus pure albis: remigibus quoque intus pure albis.

A SPECIMEN of this Shearwater was procured by Professor Giglioli, during the voyage of the "Magenta," in the South Atlantic Ocean, in Lat. $43^{\circ} 54^{\prime}$ S., Long. $9^{\circ} 20^{\prime}$ E. ; it was considered by both Count Salvadori and himself to be distinct from all known species as enumerated by Coues in his "Monograph," by reason of the fine cinereous colour of the upper parts, the only form with which it might be identified being Puffinus mundus (Kuhl), (Nectris munda, Banks, Tab. 24), but the following diagnosis of Bonaparte, the only one available, was too brief and incomplete to depend upon:- "Magnitudine Perdicis, alis cauda aliquantum brevioribus: cauda brevi, cuneiformi : rostro cyaneo-griseo, apice nigro : pedibus cyaneis, unguibus falculatis."

Though the above description partly agrees with their specimen, Professor Giglioli and Count Salvadori find that the tail is not wedge-shaped but rounded, the bill has a black culmen, the feet are not entirely blue, and there is no mention of the coloration so characteristic of the species; "fine cinereous lead-colour above, and pure white below."

The drawing to which the name of Nectris munda is attached is No. 24 of Sydney Parkinson's pictures (cf. Sharpe, Hist. Coll. Brit. Mus., II., Birds, p. 176), and bears the following note:- "The beak blue-grey towards the back, and the point black; 


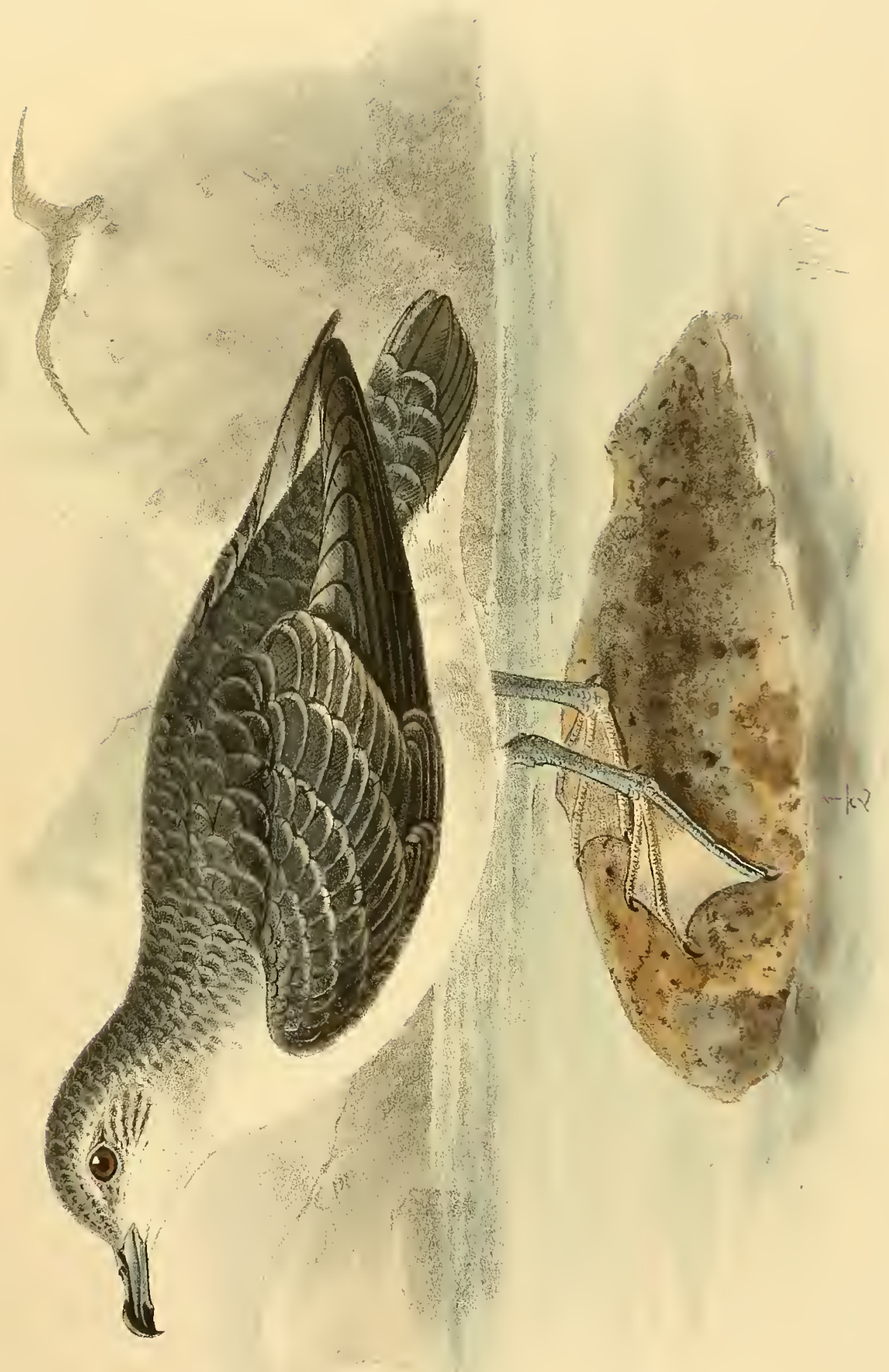





\section{PUFFINUS ELEGANS.}

the legs and feet of the same colour as in the Procellaria cyanopedo. Nectris munda, February 15, 1769. Lat. $48^{\circ} 27^{\prime}$ S., Long. $93^{\circ}$."

Parkinson's drawing is only a pencil sketch in outline, and no such name as Procellaria cyanopus was known at the time. The only species described by him as having bluish feet is Nectris fuliginosa of Solander's MSS., which is the well-known $P$.griseus, and with it Nectris munda can have no real connection (cf. Salvin, in Rowley's Orn. Misc., I., p. 256, 1876).

Salvin's opinion of $P$. elegans is stated in his article on Petrels in the "Ornithological Miscellany," as follows:- "In describing this species the authors suggest that it may be the bird indicated in Banks's drawings as Nectris munda (cf. antea, p. 236); and there appears to be some reason for this suggestion, though, after looking carefully at the drawing and Solander's MSS. note attached to this name, I see little chance, from such incomplete materials, of coming to any decision respecting it. Under these circumstances I think that the name $P$. elegans had best be adhered to, for this bird, i.e., supposing it to be a species distinct from all others. That this may ultimately prove not to be the case is suggested by the fact that the single specimen yet known is a young bird that has just thrown off its down, the remains of which are still visible; moreover, the white edgings to the feathers of the upper plumage in this specimen are so unusual in this genus that I am disposed to doubt their being characteristic of the adult bird. Still, apart from this point of doubtful value, there remains the clear cinereous colouring of the adult plumage which corresponds with that of no other species of $P$ uffinus that I am acquainted with. It is thus quite likely that $P$. elegans will stand as a distinct species."

The following is a translation of the original description of the species given by Professor Giglioli and Count Salvadori :-General colour above entirely ashyplumbeous, all the feathers very narrowly edged with white; median and greater wingcoverts as well as the secondaries edged with white, forming three bands across the wing; under wing-coverts and interior aspect of quills, white; sides of head and neck mixed with ashy-white; tail short and entirely ashy-plumbeous; hinder aspect of tarsus black, bluish in front; toes black below, bluish above; webs whitish; claws black; bill slender, bluish, the culmen and tip black; iris brown. Total length about 11.5 inches; culmen, 1.07 ; wing, 7.3 ; tail, 2.7 ; tarsus, 1.7 ; middle toe and claw, 1.95 (Salvin, Cat. Birds. Brit. Mus., XXV., p. 385).

The Plate is drawn from the type-specimen kindly lent to Salvin by Professor Giglioli, and it has also been figured in Salvin's article on Petrels in the "Ornithological Miscellany" (l.c.). 


\section{PUFFINUS BAILLONI, $B p$.}

\section{(MADEIRAN SHEARWATER.)}

Puffinus bailloni, Bp., Comptes Rend., XLII., p. 769 (1856) ; id., Consp. Av., II., p. 205 (1856).

Puffinus obscurus (nec Gm.), Bolle, J. f. O., 1856, pp. 29-30; Godman, Ibis, 1872, p. 223 ; Ogilvie-Grant, Ibis, 1890, p. 444.

Puffinus assimilis (nec Gould), Ogilvie-Grant, Ibis, 1896, p. 50 ; Boyd Alexander, Ibis, 1898, pp. 96-98, 109, 117 ; Howard Saunders, Man. Brit. Birds, 2nd ed., p. 743 (1899).

Puffinus obscurus bailloni, Rothschild and Hartert, Nov. Zool., VI., p. 196 (1899); Hartert, Nov. Zool., XII., p. 99 (1905).

Puffinus sp., Salvad., Ann. Mus. Civ. Gen. (2), XX., p. 303 (1899).

$P$. assimili propinquus, sed remigibus intus grisescenti-albis, haud pure albis: subcaudalibus pure albis, lateralibus externe nigro marginatis distinguendus.

The Madeira Petrel is closely allied to $P$. assimilis of the Australian Seas, but the quill-lining is greyer and more dusky.

In $P$. bailloni the inner webs of the quills below are greyish-white, while the under wing-coverts are, in contrast, pure white. The quill-lining is greyish or ashy-white, not dusky as in $P$. obscurus, nor of such a pure white as in $P$. assimilis. In the latter bird all the under tail-coverts are entirely white, whereas in $P$. bailloni the long lateral feathers are more or less black along their outer webs. This is the principal character which distinguishes $P$. bailloni from its allies.

Bonaparte described his Puffinus bailloni from "Isle de France" (i.e., Mauritius), and gave the following diagnosis :-_ Minimus : nigricans : subtus abrupte a rostro candidus."

The bird which inhabits the Mascarene Islands is, I believe, $P$. obscurus, and, therefore, if Bonaparte is right as regards the habitat of his species, his $P$. bailloni is identical with $P$. obscurus. The name has been attached to the Madeira and Azorean Shearwater by Dr. Hartert, who, however, did not fail to notice that there was some doubt as to its correctness, and he hints that possibly the North Atlantic form may require a new title (Nov. Zool., XII., p. 99). This is my opinion also, but for the 


\section{PUFFINUS BAILLONI.}

present I follow those ornithologists who have recognised the name of $P$. bailloni for the Madeiran species.

This small Shearwater is an inhabitant of Madeira, the Canaries, and the Rombos Islands, in the Cape Verde Archipelago, where Lieutenant Boyd Alexander found it breeding in March. In Santiago, Mozos and Fogo, islands of the same group, it has been found by Signor Fea. Captain Savile Reid records it from Tenerife, and says that it undoubtedly breeds on the detached islands to the westward (Ibis, 1888, p. 81). On the little island of Graciosa, in the Canaries, Mr. Meade-Waldo found it nesting earlier than the other Petrels, eggs being discovered at the end of February and the beginning of March (Ibis, 1890, p. 437). Mr. Ogilvie-Grant visited the island of Deserta Grande on the 4th of May, 1890, and captured a single female of this species, which had not bred. This he thought to be somewhat remarkable since, at Porto Santo, only some forty miles distant, some of the young birds were even then in nearly adult plumage (Ibis, 1890, p. 444).

Mr. Ogilvie-Grant, however, in a subsequent note (Ibis, 1891, p. 469), states that Salvin had drawn his attention to the possibility of the small Shearwaters of the Deserta Grande and Porto Santo Islands being in reality of two different species. On re-examining his specimens, Mr. Ogilvie-Grant came to the conclusion that the Porto Santo birds were $P$. obscurus, while those from Deserta Grande were $P$. assimilis, and thus the difference in the time of nesting might be accounted for.

On Great Salvage Island he procured several specimens, both adult and young, as well as an egg of this Shearwater (Ibis, 1896, p. 50). The birds which he formerly supposed to be $P$. obscurus, Mr. Ogilvie-Grant now considers to be the young of $P$. assimilis, and he believes that this species only inhabits Porto Santo, Lime Island, and Great Salvage Island. He saw a dozen adult birds in Padre Schmitz's Collection from Porto Santo, all of which he identified as $P$. assimilis.

I have examined the series obtained by Mr. Ogilvie-Grant, as above recorded, and I recognise the variation in the shade of the quill-lining, some of the birds having the inner webs of the primaries ashy-white but never approaching the pure white quill-lining of the true $P$. assimilis. As, however, the principal character of $P$. bailloni, the black edging to the lateral under tail-coverts, never fails, I consider that all the birds of the North Atlantic islands are P. bailloni, and the lighter or darker quill-lining is due to the wear and tear of the plumage.

When I visited the Azores in May, 1865, I heard of a Petrel, on the island of Flores, which could only have been $P$. bailloni. It was called "Frulho," and was said to arrive about the month of March, and to breed in the cliffs; it had reared its young and gone again before I reached Flores, nor did I obtain or see a specimen; neither did I hear of it on the other islands (Ibis, 1866, p. 104). Mr. Ogilvie-Grant met with this Shearwater on Praya Island, near Graciosa. Major Chaves told him that it was not 


\section{MONOGRAPH OF THE PETRELS.}

uncommon in the Azores, and there were specimens in the Ponta Delgarda Museum from Rosto de Cao, San Miguel, and Pico Island.

$P$. bailloni occasionally wanders into the Mediterranean, for Count Arrigoni degli Oddi states that he has a specimen from the Manzone Collection of Bra, which was received in a fresh state, and was said to have been captured off the coast of Piedmont on the 5th of October, 1895; and another was said to have been killed near Oristano, in Sardinia, in October, 1892 (Atlant. Orn., p. 526).

The British Islands have also been visited by this Shearwater, one having flown on board a small sloop off Valentia Harbour, co. Kerry, in May, 1853. The specimen was sent to Yarrell by Mr. B. Blackburn, and was identified as Puffinus obscurus. A second example was found dead near Earsham Hall, near Bungay, in Suffolk, on the 10th of April, 1858. Mr. Howard Saunders, who gives the above account of the capture of the two British specimens, states that he had examined them both, and came to the conclusion that they were referable to $P$. assimilis, but I have no doubt that they were really $P$. bailloni. Two more specimens have since been procured in England, one from Bexhill, on the 28th of December, 1900, and recorded by Mr. Butterfield (Bull. B. O. C., XI., p. 45); a second having been obtained at Lydd on the 27th of November, 1905, as stated by Dr. Ticehurst (Bull. B. O. C., XVI., p. 38).

On the Rombos Islands Lieutenant Boyd Alexander found the species nesting not only in holes, but frequently beneath rocky boulders and in small clefts and overhanging rocks, while in one instance a bird had made its nest beneath the boards of a tumble-down hut; in this last case the nest contained a quantity of dry grass. Its weird cry resembled the sounds, "Karki-karrou, Karki-karrou," which it uttered incessantly.

Mr. Ogilvie-Grant's experience in the Salvage Islands was that this species was seldom seen, but was occasionally observed during the daytime, in company with $P$. kuhli; he found it nesting in the sides of cliffs.

Adult male. General colour above black, with an ashy shade, caused by the indistinct margins of slaty-grey on the feathers of the back; wing-coverts like the back, the greater series with narrow white fringes to the ends of the feathers ; primarycoverts and quills also black, not differing from the back; tail-feathers black; crown of head black, like the back, as also the upper part of the lores; lower half of lores, sides of face, upper and lower edge of eyelid white, with a few blackish streaks on the ear-coverts; a white superciliary streak extending from the hinder part of the eye, mottled with blackish; cheeks and under-surface of body pure white, the sides of the neck also mottled with blackish bars, where the white under-surface adjoins the black of the back; on each side of the upper breast a patch of ashy-black and white; on the sides of the lower flanks a patch of black above the thighs, formed by the black inner webs to the feathers; under tail-coverts pure white, the lateral ones externally sooty- 


\section{PUFFINUS BAILLONI.}

black, and some of the longer ones entirely black; axillaries and under wing-coverts pure white; quills ashy-brown below, the inner webs hoary-whitish; " bill lead colour ; outer toe, sole, and back of tarsus black, the rest livid; iris dark brown" (OgilvieGrant). Total length about 10.5 inches; culmen, 0.95 ; wing, 7.1 ; tail, 2.5 ; tarsus, 1.45 ; middle toe and claw, 1.75 .

A male obtained by Mr. Ogilvie-Grant in the Azores (Praya Island) had the "iris dark brown; ridge of culmen and end of lower mandible blackish; latericorn, and rest of lower mandible slate-colour; legs slaty-blue, the outer aspect of the tarsus and outer toe black; middle of webs and joints dusky."

Lieutenant Boyd Alexander has the following note:- "Bill slaty-blue ; iris dark brown ; legs and feet pale blue, outer foot black; webs pale yellow ; claws brown."

The description of the male is taken from a specimen procured on Porto Santo by Padre Schmitz, on the 16th of February, 1895, and now in the Rothschild Collection. 


\title{
47. PUFFINUS CARNEIPES, Gould.
}

\author{
(PINK-FOOTED SHEARWATER.)
}

(Plate 37.)

Puffinus carneipes, Gould, P. Z. S., 1844, p. 57 ; id., Birds Austr., Fol. VII., Pl. 57 (1848) ; Seebohm, Birds Japan. Emp., p. 265 (1890) ; Buller, Birds N. Zeal., 2nd Ed., II., p. 234 (1888) ; id., Suppl. Birds N. Zeal., I., p. 103 (1905);

Salvin, Cat. Birds Brit. Mus., XXV., p. 385 (1896).

Nectris carneipes, Bp., Consp. Av., II., p. 201 (1856) ; Coues, Pr. Acad. Philad., 1864, pp. 126, 143 ; Gould, Handb. Birds Austr., II., p. 465 (1865).

Priofinus carneipes, Bp., Comptes Rend., XLII., p. 769 (1856).

Puffinus (Nectris) carneipes, Ramsay, Pr. Linn. Soc. N. S. Wales, II., p. 139 (1877) ; III., p. 406 (1879).

$P$. griseo similis, et eadem statura insignis, sed subalaribus fuliginoso-nigris, absque albedine: rostro cum naribus pedibusque carneis (in exuvie flavicantibus) distinguendus.

ThIs large Shearwater, though allied to $P$. griseus, is distinguished by its yellowish feet and bill (flesh-colour in life), and by the absence of any whitish or ashy-grey on the under wing-coverts, these being sooty-black or blackish-brown, and slightly darker than the rest of the under-surface of the body. Some writers, Salvin among the number, have suggested that Latham's " Kurile Petrel " (Gen. Syn. Birds, III., Pl. 2, p. 399, 1785 ; undè Procellaria axquinoctialis, Var. A., Lath., Ind. Orn., II., p. 821, 1790) is probably Puffinus carneipes. But in this I cannot agree, for Latham makes his bird a variety of Procellaria aquinoctialis, which is the well-known Majaqueus, or "Cape Hen." If, as he says, his "Kurile Petrel" is "half as large again, with a strong yellow bill," it more closely resembles an Albatros, and is probably Diomedea albatrus. In any case, it could hardly be Puffinus carneipes.

Gould, who described the bird, says that all the specimens and eggs received by him were from the islands off Cape Leeuwin. Mr. A. J. Campbell (Nests and Eggs of Birds of Austr., II., p. 880) gives the habitat as the "seas of Western Australia, and probably other parts of the southern coasts, including Tasmania." Mr. Ernest Saunders 


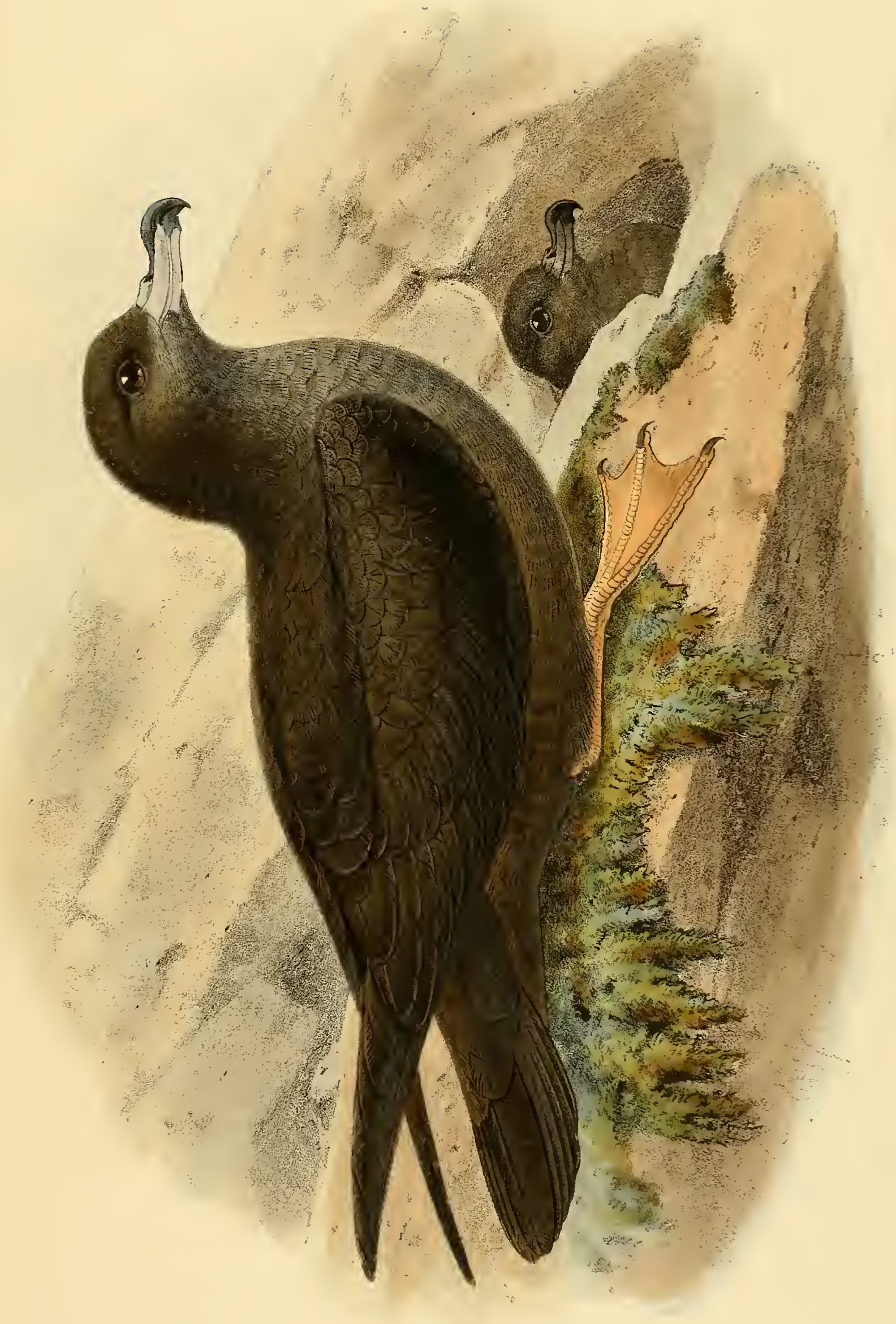




\section{PUFFINUS CARNEIPES.}

procured specimens on Norfolk Island and Lord Howe Island (Salvin, Cat. Birds Brit. Mus., XXV., p. 386 ; North, Rec. Austr. Mus., V., Part 2, p. 126, 1904).

Dr. E. P. Ramsay, who has written an account of P. carneipes (Pr. Linn. Soc. N.S.W., III., p. 406, 1879), says that it represents $P$. tenuirostris on the coasts of New South Wales and South Australia, where it is as numerous as that species in certain places. $\mathrm{He}$ further states that these Shearwaters frequent the Solitary Islands in great numbers during the breeding season, which extends from September till December.

Sir Walter Buller relates that $P$. carneipes breeds in large colonies on some of the small islands, and is comparatively common off the coast of New Zealand-Captain Fairchild procured two living birds for him, which he found nesting on White Island in the beginning of November. After the breeding season in Australia, $P$. carneipes passes north to the seas of Japan, but has not yet been found in the intervening area, nor is it known to nest in its northern habitat. Mr. Seebohm, who records its occurrence in Japanese waters, observes that it is probably a non-breeding summer visitor in the North Pacific, and supposing this to be correct, we may regard P. carneipes as a Petrel which, like Oceanites oceanica, breeds in the southern hemisphere during our winter, and visits the northern hemisphere during our summer, but in the latter instance without breeding.

The nesting habits resemble those of other species of the genus. Dr. Ramsay (l. s. c.), in acknowledging the receipt by the Australian Museum of a fine series of birds and eggs from the Solitary Islands, gives the following notes, derived from his correspondents :- The birds arrived early in September, and at once began excavating their nesting-holes, which consisted of short burrows, about six inches in diameter, and from twelve to twenty inches in length. The eggs were laid at night, but in no instance was more than one obtained in a burrow. Although both sexes assisted in the incubation, out of five specimens taken from the burrows, four proved to be females. The birds arrived in countless thousands in the evening, and most of them-the males probably, or those not engaged in hatching-returned to sea at daybreak.

Gould says (Handb. Birds Austr., II., p. 465) that the eggs in his possession were white, $2 \frac{7}{8}$ inches in length, by nearly 2 inches in breadth.

Dr. E. P. Ramsay states that those sent to him from South Solitary Island, near Port Stephens, were mostly of an oval form, and measured 2.33-2.47 inches in length, by 1.5-1.7 inch in breadth, and were of a smooth, fine grain. One specimen, sent by Mr. McLeod, was more pointed at the thin end, and had very light brown irregular blotches at the thicker end. The shell was slightly different in texture, and the egg might have belonged to a species of Tern, but it was undoubtedly taken from one of the Petrel's burrows.

Adult. General colour above sooty-black, with faintly indicated edgings of lighter ashy-brown; the longer scapulars rather blacker than the back, resembling the wing-coverts and quills, which are also somewhat blacker than the dorsal region; 


\section{MONOGRAPH OF THE PETRELS.}

quills blackish externally, but ashy or ashy-brown on the inner webs; tail black; crown of head and sides of face sooty-black like the back, with a slight tinge of ashy-grey on the lores and ear-coverts ; cheeks and under-surface of the body sooty-brown, with a distinct shade of grey on the fore-part of the cheeks and throat, but with scarcely any grey on the breast and abdomen; under wing-coverts and axillaries sooty-brown, darker than the breast. Total length about 19 inches; culmen, 1.8 ; wing, 12.5 ; tail, 4.3 ; tarsus, 2.2 ; middle toe and claw, 2.7 .

The adult female appears to differ in no way from the male as regards colour, nor do the measurements vary much, as will be seen from the following list of specimens examined by me:-

a. b. $\delta^{\pi}$ ad Hakodate (Blakiston:

Wing. Tail. Culmen. Tarsus. $\quad \begin{aligned} & \text { Middle toe } \\ & \text { snd claw. }\end{aligned}$

$$
\begin{array}{lllllll}
\text { Mus. Brit.) . . } & \text {. } & 12.4-12.6 & 4.4-4.45 & 1.65 & 2.0-2.1 & 2.55-2.7
\end{array}
$$

c. $\quad+$ ad. Hakodate (Blakiston: Mus. Rothschild) $\quad$. 12.3

d. e. $\quad$ ad. Hakodate (Mus. Brit.)

12.4-12.8

d. e. ad. NorfolkIsl. (Mus. Brit.)

$12.0-12.5$

4.5

1.5

2.1

2.75

$4.2-4.45 \quad 1.6$

2.1

2.6

t. ad. New Zealand (Buller:

$4.15-4.3$

$1.65-1.75 \quad 2.2$

2.6-2.7

(Mus. Rothschild) . .

12.4

$-\quad 1.6$

2.2

2.8

$g$.

ad. KarewhaIsl. N.Z.(Reischek: Mus.Rothschild)

12.4

$4.3 \quad 1.65$

2.15

2.55

The colour of the bill and feet, on the other hand, appears to vary considerably. Gould says that the bill is "fleshy white; the culmen and tips of the mandibles brown; the legs, feet, and inter-digital membrane yellowish flesh-colour" (Handb. Birds Austr., II., p. 466). Reischek's specimen from Karewha Island had the " eyes dark bluish-black; the feet flesh-colour, yellowish on the webs; bill flesh-colour, with a yellowish tinge, the tip brownish-black." Dr. Ramsay, from living specimens, gives the colours as follows:- "Iris blackish-brown; legs and feet pale flesh-colour; bill dark brown above, lighter below" (Pr. Linn. Soc. N.S.W., III., p. 406). Buller, who also had living specimens before him, writes:-“ Iris black; bill yellowish horn-colour, brownish-black at the tips of both mandibles and along the culmen to the opening of the nostrils ; legs and feet dull flesh-colour ; the webs pale brown."

The specimen described is in the British Museum, and was obtained by Mr. Ernest Saunders on Norfolk Island. The Plate represents a bird from Hakodate in our collection. 
. 


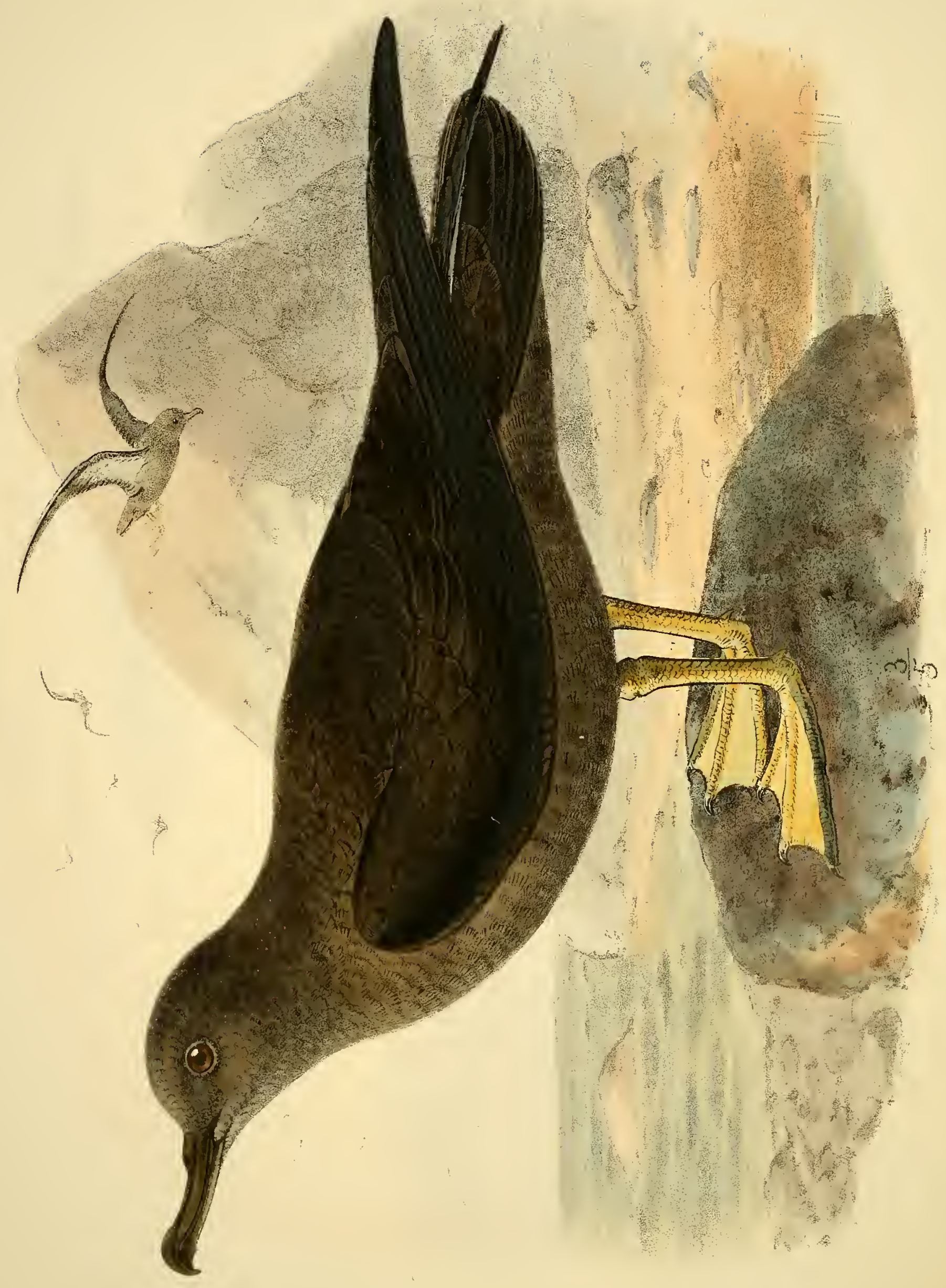

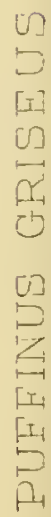




\title{
48. PUFFINUS GRISEUS ( $G m$.).
}

\author{
(SOOTY SHEARWATER.)
}

\section{(Plate 38.)}

Grey Petrel, Latham, Gen. Syn., III., pt. 2, p. 399 (1785).

Nectris fuliginosa (nec Kuhl), Solander MSS. ; Parkinson, Icon. Ined., No. 23.

Procellaria fuliginosa, G. Forster, Icon. Ined., No. 94.

Procellaria grisea, Gm., Syst. Nat., I., p. 564 (1788) ; Kuhl, Beitr., p. 144 (1820).

Daption griseum, Stephens, in Shaw's Gen. Zool., XIII., p. 246 (1826).

Puffinus fuliginosus, A. Strickland, P. Z. S., 1832, p. 129 ; Coues, Key N. Amer. Birds, 2nd ed., p. 787 (1884).

Puffinus cinereus (nec Gm.), Gould, Birds Eur., V., Pl. 445, fig. 2 (1837).

Puffinus tristis, J. R. Forster, Descr. Anim., ed. Licht, p. 23 (1844); Buller, Birds N.

Zeal., p. 317 (1873).

Puffinus major (nec Faber), Gray, Voy. "Erebus and Terror," I., Birds, p. 17 (1840).

Nectris fuliginosus, Bp., Consp. Av., II., p. 202 (1856); Coues, Pr. Acad. Philad., 1864, pp. $125,143$.

Nectris chilensis, Bp., Consp. Av., II., p. 202 (1856).

Nectris amaurosoma, Coues, Pr. Acad. Philad., 1864, p. 124.

Puffinus amaurosoma, Giglioli, Faun. Vertebr. Oceano, p. 34 (1870); id., Viagg. "Magenta," pp. 844, 861 (1875) ; Coues, Checklist N. Amer. Birds, p. 129 (1882).

Puffinus griseus, Finsch, J. f. O., 1874, p. 209 ; Salvin, in Rowley's Orn. Misc., I., p. 236 (1876) ; id., Ibis, 1888, p. 355 ; Baird, Brewer, and Ridgway, Water-Birds N. Amer., II., p. 391 (1884) ; Salvin, Cat. Birds Brit. Mus., XXV., p. 386 (1896).

Puffinus stricklandi, Ridgway, in Baird, Brewer and Ridgway, Water-Birds N. Amer., II., p. 390 (1884).

Cauda rotundata, 3.2-3.75 poll. : omnino fuliginoso-brunneus : sub-alaribus griseo-albis, rhachidibus nigris, itaque plagam albam subalarem conspicuam exhibentibus.

Puffinus griseus is distinguished from the other short-tailed, dusky-coloured, members 


\section{MONOGRAPH OF THE PETRELS.}

of the genus by the whitish area of the under wing-coverts, which have dusky-brown or blackish shaft-stripes. This Shearwater breeds in southern latitudes, and afterwards ranges into the North Pacific and North Atlantic Oceans. It was first figured, in the Banksian Collection of Drawings, by Sydney Parkinson and George Forster, under the names of Nectris fuliginosa and Procellaria fuliginosa, but these names were not published at the time.

This is the "Dark Grey Petrel" of Captain Cook's narrative of his Voyages, 17721775 (Vol. I., p. 258), and is likewise the "Grey Petrel" of Latham (Gen. Syn., III., pt. 2, p. 399). The latter author says that the specimen described by him was in the Leverian Museum, and was the "size of a Jackdaw; length 14 or 15 inches; bill 2 inches long, and brown; the whole plumage black or sooty; the under wing-coverts white, with black shafts; the wings rather exceed the tail in length; the fore-part of the legs greenish-blue." He states that the species inhabits the Southern Hemisphere, from 35 to $50^{\circ}$.

It is a species of large size, with the wings 10.5-12.1 inches in length. Salvin in his "Key" says that they measure not less than 12.5 inches, but in his description (Cat. Birds Brit. Mus., XXV., p. 387) he gives the wing as 12 inches, which is a more exact dimension.

Of $P$. griseus we have no record in the Pacific Islands, but Buller says that it is common off the coast of New Zealand, breeding on the islands of Kapiti, Karewa, and on the Rurima rocks, also on the Kaimanawa Ranges, as well as in the hills behind Wellington. Other nesting places are Whale Island, the south-east coast of Otago, and on Stewart's Island (Birds N. Zeal., 2nd ed., II., pp. 232-233).

Specimens from the Snares Islands are in the Rothschild Museum, obtained by Mr. Danneford and Mr. H. H. Travers. The species occurs on the Chatham Islands (Hutton, Ibis, 1872, p. 248), and it was procured on the Auckland Islands by the Antarctic Expedition (Salvin, l.c., p. 388), and during the voyage of the "Discovery" by Dr. Wilson (Rep. Nat. Antarctic Exped., II., Aves, p. 80 (1907).

$P$. griseus was obtained in the Cape Seas by Sir Andrew Smith, and the late C. J. Andersson observed it off the mouth of the Orange River from May to September, while a specimen from Katumbella, in Benguela, procured by Dr. Ansorge, is in the Rothschild Collection. Dr. Lucan and M. Petit record it from Landana, near the mouth of the Congo.

Although not yet observed in the Mediterranean Sea, the Sooty Shearwater occurs off the Portuguese and French coasts.

Mr. Howard Saunders (Man. Brit. Birds, 2nd ed., p. 739) calls attention to the fact that for many years $P$. griseus was mistaken for the young or a dark form of $P$. gravis, and consequently some difficulty arises as to the identification of the earlier specimens recorded in Britain. He considers, however, that though rarer than P.gravis, authentic instances of the capture of the Sooty Shearwater in our seas have been recorded, 


\section{PUFFINUS GRISEUS.}

during the summer and autumn, at North Berwick; near Newbiggin, in Northumberland ; on the coast of Yorkshire, especially off Flamborough ; near Lynn, in Norfolk ; and in the Channel, from Sussex to Cornwall.

In Ireland individuals have been procured on the coast of Kerry, and in Belfast Lough. Since the publication of the second edition of the "Manual" the Sooty Petrel has been obtained off Dungeness Point, in Kent, on the 14th of October, 1907, being the first record for the county (N. F. Ticehurst, British Birds, I., p. 264, 1908). Mr. Eagle Clarke has also recorded it from Stromness, in the Orkneys (Ann. Scott. Nat. Hist., 1903, p. 410), and Mr. Evans from the Forth area (t.c., p. 26).

The range of $P$.griseus extends to the Orkneys and Faeroe Islands, and a specimen procured by Mr. H. C. Müller, in August, 1873, is in the Hargitt Collection in the British Museum. On the coast of North America it was seen by Colonel Feilden, in company with $P$. gravis, sixty miles to the south of Cape Farewell, on the 22nd of June, 1875, and he was informed that it was common off the coast of Labrador. It is likewise plentiful in the Bay of Fundy, off the coasts of Nova Scotia and New Brunswick. Mr. Ridgway states that this species is at times very abundant in August off the coast of Massachusetts, and in the latter part of that month, during stormy weather, a large number were driven into Wood's Hole.

Mr. Ridgway has separated the Sooty Shearwater of the Atlantic, to which he gives the name of $P$. stricklandi, from that of the Pacific Ocean, which he regards as the true Puffinus griseus (Gmelin). The Pacific bird he compares with P. gravis, but says that it is slightly smaller in its measurements; the bill is decidedly more slender, and the tarsus and middle toe are nearly of the same length (Water-Birds N.Amer., II., p. 390). Salvin recognised but one species, and in this I agree.

The western range of $P$. griseus is given in the "A. O. U. Checklist" (2nd ed., p. 33) as follows:- "South Pacific, north on the American coast, casually to San Francisco, California." Mr. Loomis (Pr. Calif. Acad. Sci. (2), VI., p. 27, 1896) records the species from Monterey in December and January, and it extends north to Washington State, where Mr. Kobbé ( $A u k$, XVII., p. 349) says that an example was obtained at Fort Canby, at the mouth of the Columbia River. It is said to be abundant near Tillamook Lighthouse, which is about twenty miles south of Cape Disappointment. In the North Pacific P. griseus was obtained by Captain Blakiston and Mr. W. J. Snow on the Kuril Islands, and specimens, procured as far north as Urup, are in the Seebohm Collection.

$P$. griseus undoubtedly passes on migration down the coast of North America to the extreme south. Specimens were obtained by Xantus off Cape St. Lucas, in Lower California (Bryant, Pr. Calif. Acad. Sci., (2) II., p. 252, 1889), by Darwin off Corral, in Chile (where Mr. A. A. Lane has also often met with it), while Mr. Nicoll obtained it in Valparaiso Bay, where flocks of hundreds were seen. The Rothschild Collection contains a specimen from San Vicente. Mr. Aplin records examples from off the 


\section{MONOGRAPH OF THE PETRELS.}

coast near the Castillo rocks, in Uruguay, on October 1st, and also on the 10th of June (Ibis, 1894, p. 212).

In habits $P$. griseus does not differ from $P$. gravis. It breeds in great numbers on some of the small islands off the coast of New Zealand, the nesting places being much harried by the natives, who esteem these Shearwaters as an article of food. The burrows on the Chatham Islands are usually formed in peaty soil, running horizontally for three or four feet and then turning. The nest, a rude structure composed of sticks and dead leaves, is placed at the end of the hole. A single egg is laid, both sexes assisting in the work of incubation, and when the parents return to roost on shore in countless thousands, the noise they make is deafening. If removed from their burrows they flutter about on the ground for some time in a confused way, but eventually make for the sea. Dr. Crowfoot gives the dimensions of eggs taken on Norfolk Island as : Axis, 2.5-2.75 inches ; diam., 1.5-1.75.

Adult female. General colour above dark-brown, with obsolete margins of paler brown to the feathers; the scapulars darker and inclining to blackish towards their ends; wing-coverts more blackish-brown than the back; the quills black, sometimes with a slight greyish gloss, and paler on the inner webs; lower back, rump, and upper tail-coverts rather blacker than the back; tail-feathers black; head and neck like the back; sides of the face slightly paler and more sooty-black, with the lower edge of the eyelid white; entire under-surface of body dusky-brown, with a shade of ashy, more distinctly seen on the sides of the face and throat; axillaries sooty-brown, rather darker than the breast; under wing-coverts for the most part ashy-white, with blackish shaft-lines, and shaded or mottled with ashy-brown towards the ends, the coverts round the edge of the wing browner; quills dusky-brown below, slightly greyer on the inner webs; "bill dull greyish-black, inclining to yellowish-brown on the ridge; tarsi and toes bluish-grey, the webs yellowish; iris black" (W. L. Buller). Total length, 16.0 inches ; culmen, 1.7 ; wing, 11.8 ; tail, 3.4 ; tarsus, 2.3 ; middle toe and claw, 2.8. Adult male. Similar to the female. Total length, 17.5 inches; culmen, 1.6 ; wing, 12.0 ; tail, 3.5 ; tarsus, 2.3 ; middle toe, 2.7 .

The description of the female is taken from a specimen in the Hargitt Collection, obtained by the late H. Müller in the Faeroes. The male is from Otago, New Zealand, in the Hume Collection. 



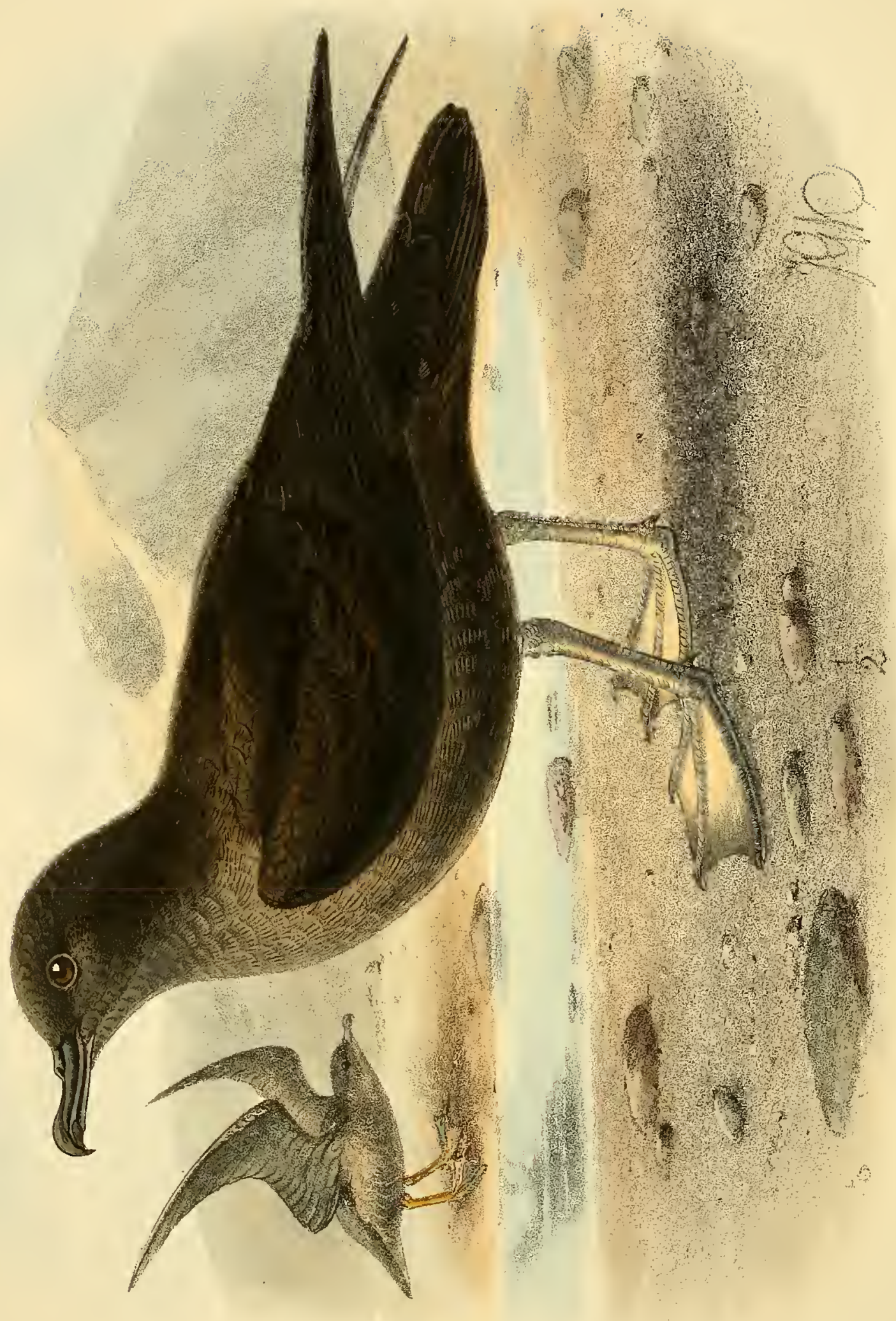




\title{
49. PUFFINUS TENUIROSTRIS (Temm.).
}

\author{
(SHORT-TAILED SHEARWATER.)
}

(Plate 39.)*

Procellaria tenuirostris, Temm., PI. Col., text to Pl. 587 (1835) ; id., and Schl., Faun. Japon, p. 131, PI. 86 (1842).

Puffinus brevicaudus, Brandt, Icon. Ross., Av., taf. 6, fig. 17 (1836); Gould, Birds Austr., fol. VII., Pl. 56 (1847) ; Buller, Birds N. Zèal., p. 315 (1873).

Puffinus tenuirostris, Gray, List Anseres, Brit. Mus., p. 160 (1844); Salvad., Orn. Papuasia, III., p. 462 (1882); Baird, Brewer, and Ridgway, Water-Birds N. Amer., II., p. 392 (1884) ; Seebohm, Birds Japan. Emp., p. 267 (1890); Salvin, Cat. Birds Brit. Mus., XXV., p. 388 (1896).

Nectris tenuirostris, Bp., Consp. Av., II., p. 202 (1856) ; Coues, Proc. Acad. Philad., 1864, pp. 126, 143.

Nectris brevicauda, Bp., Consp. Av., II., p. 201 (1856) ; Gould, Handb. Birds Austr., II., p. 459 (1865).

Puffinus curilicus, Bp., C. R., XLII., p. 769 (1856).

Priofinus brevicauda, Bp., t.c., p. 769 (1856).

Procellaria curilica, Kittl. Denkwürd., I., p. 296 (1858).

Puffinus obscurus (nec Gm.), Elwes, Ibis, 1859, p. 397.

Puffinus brevicaudatus, Finsch, J. f. O., 1870, p. 371.

Priocella tenuirostris, Nelson, Cruise "Corwin," p. 152 (1883).

Cauda rotundata, breviore, 3.25-3.6 poll. : ubique fuliginoso-brunneus.

THIS species is very similar in appearance to $P$. chlororhynchus, but is distinguished by its more slender bill and especially by the form of the tail, which is short and rounded, not wedge-shaped, as in the above-mentioned bird.

On this account it was called $P$. brevicaudus by Brandt and Gould, and it was some time before ornithologists discovered that the Short-tailed Shearwater mas identical with Procellaria tenuirostris of Temminck. The type of the latter was procured in the Japanese Seas during the voyage of Von Siebold. The species has since been

* Lettered $P$. brevicauda on the Plate. 


\section{MONOGRAPH OF THE PETRELS.}

obtained in many other parts of Japan, and on the coast of Corea. Other localities are Peel Island, in the Bonin group, Miednoi Island, where it was rare, and Bering Island, from whence I have examined three specimens in the British Museum, collected by Captain Barrett-Hamilton.

Mr. Ridgway (Water-Birds of N. Amer., II., p. 393) says that this species appears to be exclusively an inhabitant of the North Pacific coasts. Mr. Dall states that a specimen was brought to him by an Eskimo, from Kotzebue Sound, where it was called "Minklok tingmynk," or "Seal-bird," as it is only found with the seals, and follows them in their migrations. It probably occurs along the western coast of North America, on passage, as it has been found in great numbers near Monterey, in California, in December, by Mr. Maillard. He believed that these Shearwaters were late migrants on their way to their breeding habitat in the Southern Hemisphere.

In Australia, $P$. tenuirostris is said by Mr. A. J. Campbell to occur in the seas of South Queensland, New South Wales, Victoria, South and West Australia, and Tasmania, and it breeds in great numbers in the islands of Bass's Straits.

It is reported as nesting on Lord Howe Island by Mr. Robert Etheridge, arriving in the latter days of August and frequenting the east end of the island, where rookeries, extending from the edge of the cliffs for a considerable distance inland, were found (Man. Austr. Mus., Sydney, No. 2, p. 14).

From Sir Walter Buller we learn that this Shearwater is very abundant on the coasts of New Zealand, breeding inland sometimes at a distance of fifty miles. The birds return annually in large colonies, and repair to their old burrows. There is said to be an extensive nesting ground in the Kaimanawa Ranges, in the Taupo-Patea country (Birds $N$. Zeal., p. 315, 1873).

In the British Museum is a specimen presented by Mr. W. D. Cumming, which was obtained by Mr. Walter Scott, at Ormara, on the Mekran coast, about one hundred and twenty-five miles from Karachi, in May, 1899. Strong south-westerly winds had been blowing, and the weather had been generally unsettled for two or three days previously.

$P$. tenuirostris is still met with in very large numbers in Australian waters, although, owing to the great destruction of the breeding places, it may be doubted if the birds exist in the same prodigious flocks as of yore.

Gould writes (Handb., II., p. 459, 1865) :-_"This bird is an inhabitant of the seas surrounding Tasmania and the islands in Bass's Straits, to some of which, but especially to Green Island, it resorts during the summer in countless numbers for the purpose of breeding and rearing its young. I visited this island in January, 1839, when, although the season was far advanced, both eggs and young were still so numerous as to excite my astonishment. . . ." Mr. Davies, in the second volume of the "Tasmanian Journal," states that "about the commencement of September these birds congregate in immense flocks, and shortly afterwards proceed at sunset to the different isles upon which they have established their rookeries. Here they remain during the night for the space of 


\section{PUFFINUS TENUIROSTRIS.}

about ten days, forming their burrows and preparing for the ensuing laying-season. They then leave, and continue at sea for about five weeks."

"About the 20th of November at sunset, a few come in to lay, and gradually increase in numbers until the night of the 24th. Still there are comparatively few, and a person would find some difficulty in collecting two dozen eggs on the morning of that day."

"It is not in my power to describe the scene that presents itself at Green Island on the night of the 24th of November. A few minutes before sunset flocks are seen making for the island from every quarter, and that with a rapidity hardly conceivable ; when they congregate together, so dense is the cloud, that night is ushered in full ten minutes before the usual time. The birds continue flitting about the island for nearly an hour, and then settle upon it. The whole island is burrowed; and when I state that there are not sufficient burrows for one-fourth of the birds to lay in, the scene of noise and confusion that ensues may be imagined-I will not attempt to describe it. On the morning of the 25 th the male birds take their departure, returning again in the evening, and so they continue to do until the end of the season. . . Every burrow on the island contains, according to its size, from one to three or four birds, and as many eggs ; one is the general rule. At least three-fourths of the birds lay under the bushes, and the eggs are so numerous that great care must be taken to avoid treading upon them. The natives from Flinders generally live for some days on Green Island at this time of the year for the purpose of collecting the eggs, and again in March or April for curing the young birds. . . . Besides Green Island, the principal rookeries of these birds are situated between Flinder's Island and Cape Barren, and most of the smaller islands in the Furneaux group. The eggs and cured birds form a great portion of the food of sealers, and, together with the feathers, constitute the principal articles of their traffic. The mode by which the feathers are obtained has been described to me as follows:"The birds cannot rise from the ground, but must first go into the water; in effecting which they make numerous tracks to the beach similar to those of a kangaroo; these are stopped before morning, with the exception of one leading over a shelving bank, at the bottom of which is dug a pit in the sand; the birds, finding all avenues closed but this, follow each other in such numbers, that, as they fall into the pit, they are immediately smothered by those succeeding them. It takes the feathers of forty birds to weigh a pound; consequently sixteen hundred must be sacrificed to make a feather bed of forty pounds weight.' Notwithstanding the enormous annual destruction of these birds, I did not, during the five years that I was in the habit of visiting the Straits, perceive any sensible diminution in their number. The young birds leave the rookeries about the latter end of April, and form one scattered flock in Bass's Straits. I have actually sailed through them from Flinder's Island to the heads of the Tamar, a distance of eighty miles. They shortly afterwards separate into dense flocks, and finally leare the coast. The old birds are very oily, but the young are literally one mass of fat, 


\section{MONOGRAPH OF THE PETRELS.}

which has a tallowy appearance, and hence I presume the name of 'Mutton-bird.' To this I may add that the young birds are very good when fresh, and the old birds after being skinned and preserved in lime, are excellent eating."

In addition to the account given by Gould an interesting paper on the habits of the "Mutton-bird" has been written by Bishop Montgomery (Ibis, 1898, pp. 209-216), and in the volumes of the "Emu" there are also several notes on the subject, notably those by Messrs. Campbell and Mattingley (Emu, VI., p. 190, 1907), and Captain Walter (Emu, II., p. 219, 1903).

Adult male. General colour above sooty-black, with obsolete margins of lighter brown to the feathers of the upper-surface; wing-coverts like the back, with the same obsolete paler edges, which are slightly greyer at the ends of the greater coverts and secondary quills; bastard-wings and primary-coverts and quills black; the inner primaries slightly shaded with ashy-grey, the secondaries rather browner than the primaries; tail-feathers black; head like the back, sooty-black; sides of face also sooty-black, greyer on the lores, cheeks, and throat; under-surface of body sooty-brown, with obsolete ashy edgings to the feathers; under tail-coverts uniform sooty-brown; under wing-coverts dull ashy-grey, mottled with sooty-brown round the entire edge of the wing; axillaries sooty-brown; quills blackish below, with an ashy shade along the inner webs for nearly the entire length; "bill black, the edges of the upper mandible from the middle of the bill to the base, greyish; the two ridges at base of lower mandible brownish-black; tarsi and feet light grey, black behind, dusky on outer sides" (P. A. Holst). Total length, 14.0 inches ; culmen, 1.2 ; wing, 10.1 ; tail, 3.35 ; tarsus, 1.95 ; middle toe and claw, 2.4.

Adult female. Similar to the male in colour. Total length, 12.5 inches ; culmen, 1.2 ; wing, 10.4 ; tail, 3.0 ; tarsus, 2.0 ; middle toe and claw, 2.3.

The principal variation in the colour of this species consists in the browner or greyer under-surface, and in the amount of grey on the sides of the face and throat.

Buller says that the young bird has the bill darker, being of a more uniform brownish-black, very slightly paler along the under-edge of the lower mandible. The same observer states that, in an adult male, the bill was blackish-brown, the under mandible paler; legs and feet vinous-grey, the webs yellowish flesh-colour, blackishbrown toward the edges.

The male described is one obtained on Peel Island, Bonin, by P. A. Holst, in the Seebohm Collection, and the female is from our collection, from Nagasaki (Captain St. John). The specimen figured is a bird from South Australia also in our collection. 



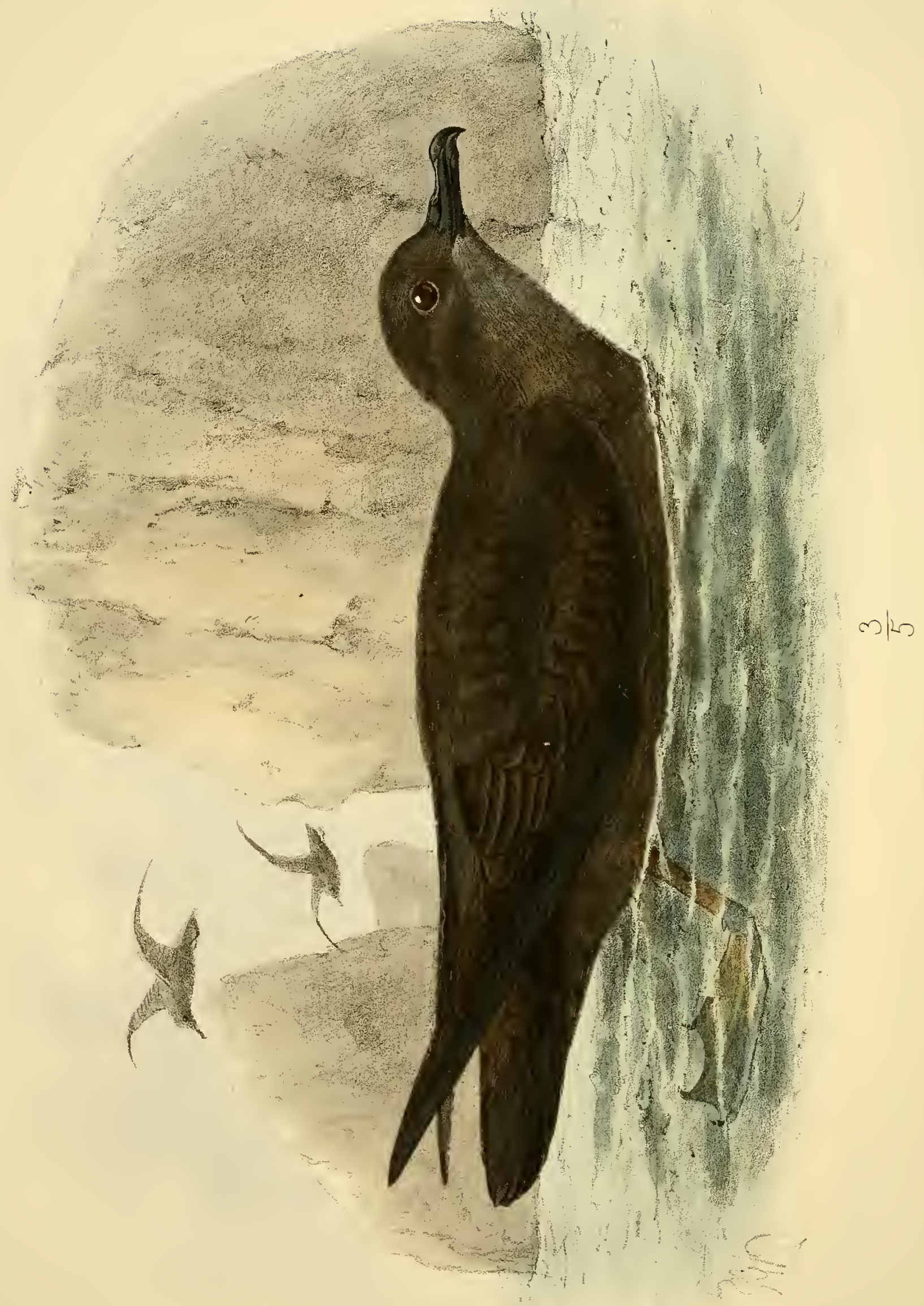




\title{
50. PUFFINUS NATIVITATIS, Streets.
}

\author{
(CHRISTMAS ISLAND SHEARWATER.)
}

(Plate 40.)

Puffnus (Nectris) nativitatis, Streets, Bull. U. S. Nat. Mus., No. 7, p. 29 (1877).

Puffinus nativitatis, Ridgw., Man. N. Amer. Birds, p. 62 (1887) ; Lister, P. Z. S., 1891, pp. 295, 300 ; Wiglesw., Abhandl. K. Mus., Dresden, 1890-91, No. 6, p. 81 (1891) ; Salvin, Cat. Birds Brit. Mus., XXV., p. 389 (1896); Rothsch., Avif. Laysan, I., p. 45, Pl. 28 (1893) ; Oates, Cat. Eggs Brit. Mus., I., p. 156 (1901) ; W. K. Fisher, Auk, 1903, p. 386.

P. tenuirostri similis, sed minor: subtus fuliginoso-niger: subalaribus et axillaribus dorso concoloribus, fuliginoso-nigris, minime grisescentibus vel albicanti-griseis.

Puffinus nativitatis, although allied to $P$. tenuirostris, is much smaller, and differs in colour, being of a dark sooty-brown below, almost chocolate in tint, from the base of the bill to the under tail-coverts, and showing no sign of white or grey on the throat. $P$. tenuirostris is paler below, being somewhat grey, and having the under wing-coverts silvery or ashy-grey, with the quill-lining pale ashy-grey. The throat is also whitish-grey.

In $P$. nativitatis the under wing-coverts are uniform sooty-black, not of the same sooty-brown colour as the breast, but darker, and resembling the back.

The species was first described by Mr. Streets from Christmas Island, in the Pacific, in 1877. It was afterwards met with in the Phœnix Group, on Phœnix and Canton Islands, by Mr. J. J. Lister. In the spring of 1883, Mr. H. J. Snow obtained specimens on Krusenstern Island, in the Marshall Group (Salvin, Cat. Birds Brit. Mus., XXV., p. 389).

In the collection of the Hon. Walter Rothschild are three examples from Laysan Island, procured by Dr. Schauinsland, and the first illustration of the species appears in Mr. Rothschild's work, the "Avifauna of Laysan" (I., p. 45, Pl. 28). Mr. Walter K. Fisher, who visited this archipelago in 1902, found this Shearwater very common there (Auk, 1903, p. 386).

Mr. Beck obtained an example (now in the Rothschild Collection) at sea, in Lat. 


\section{MONOGRAPH OF THE PETRELS.}

$12^{\circ} 50^{\prime} \mathrm{N}$., Long. $107^{\circ} \mathrm{W}$. Mr. Lister obtained but one egg at Phœnix Island, and this was found in the interior of a heap of rough coral blocks, piled together by the guano-diggers. It was pure white, of a long oval shape, and measured 2.3 inches in length, and barely 1.5 inch in breadth. Mr. Oates makes the diameter of the same egg 1.45 inch (Cat. Eggs Brit. Mus., I., p. 156).

Mr. Palmer met with this species on Laysan, and also on French Frigate Island (Rothschild, Avif. Laysan, I., p. 45). On the latter he found it breeding, laying its eggs on the ground, and not burrowing like its congeners. The nest, on which both parent birds were often sitting side by side, was composed of a little grass, whereon a single egg was laid. Mr. Rothschild gives the following dimensions :-Axis, 2.24-2.37 inches; diam., 1.35-1.45.

Adult male. General colour above sooty-black; wing-coverts and scapulars like the back; quills and tail black, the latter slightly brown at the extreme base; head a little blacker than the rest of the back; entire under-surface somewhat lighter than the back, and inclining to smoky-brown; under wing-coverts and axillaries like the breast; lower greater-coverts and quill-lining with a slight ashy gloss; bill and feet black (J. J. Lister). Total length 14 inches; culmen, 1.25 ; wing, 9.8 ; tail, 3.55 ; tarsus, 1.7 ; middle toe and claw, 1.9.

Adult female. Similar to the male. Total length 13.5 inches; culmen, 1.3; wing, 9.8 ; tail, 3.4 ; tarsus, 1.75 ; middle toe and claw, 2.5.

A nestling in the Rothschild Collection is covered with sooty down, with a slight reddish tinge on the head, and with the under-surface of the body rather greyer. The series examined by me gives the following measurements :-

\begin{tabular}{|c|c|c|c|c|c|c|}
\hline a. & Krusenstern Isl. (Mus. Brit.) & $\begin{array}{r}\text { Wing. } \\
\ldots \quad 10.0\end{array}$ & $\begin{array}{l}\text { Tail. } \\
3.35\end{array}$ & $\begin{array}{c}\text { Culmen. } \\
1.2\end{array}$ & $\begin{array}{c}\text { Tarsus. } \\
1.7\end{array}$ & $\begin{array}{c}\text { Middle toc } \\
\text { and claw. } \\
2.1\end{array}$ \\
\hline$b$. & Do. & 9.6 & 3.4 & 1.15 & 1.8 & 2.0 \\
\hline c. $\delta^{\pi}$ & Phoenix Isl. & 9.8 & 3.55 & 1.25 & 1.7 & 1.9 \\
\hline d. $\delta$ & Laysan Isl. (Mus. Rothschild.) & 9.5 & 3.25 & 1.25 & 1.75 & 2.0 \\
\hline q & Do. & . 9.5 & 3.35 & 1.2 & 1.65 & 1.85 \\
\hline f. $\quad$ + & Do. & . 9.8 & 3.4 & 1.3 & 1.75 & 2.5 \\
\hline
\end{tabular}

g. ơ Lat. $12^{\circ} 50^{\prime}$ N., Long. $107^{\circ}$ W. (Mus.

$$
\begin{array}{lllllllll}
\text { Rothschild ) . . } & \ldots & \ldots & \ldots & 9.7 & 3.2 & 1.3 & 1.7 & 1.9
\end{array}
$$

The wing-measurement varies from 9.5-10 inches, and the tarsus from 1.65-1.8 inch, but, as far as one can judge, there is no material difference in the dimensions of the sexes. The tail measures from 3.2 to 3.55 inches.

The specimen figured is the type kindly lent by the authorities of the U. S. National Museum. The description of the male is that of the Phœnix Island example in the British Museum, and the female is described from a Laysan bird in the Rothschild Collection. 


A

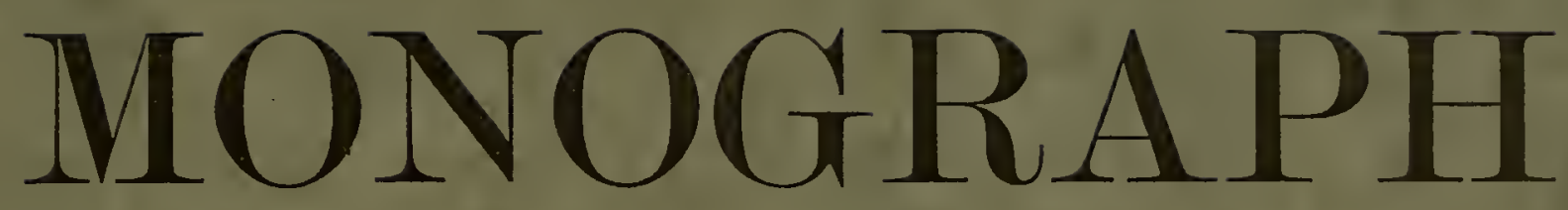

OF THE

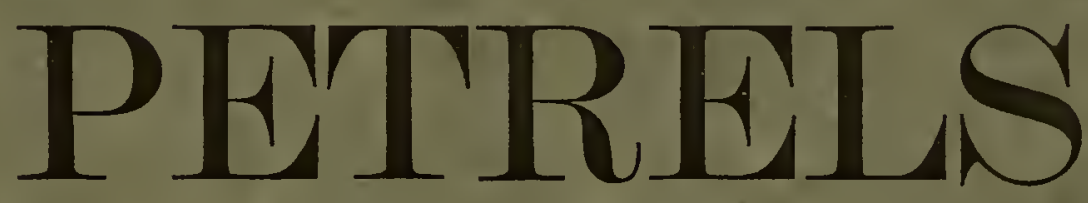

(ORDER TUBINARES)

BY

\section{F. DU CANE GODMAN}

D.C.L. F.R.S. PRESIDENT OF THE BRITISH ORNITHOLOGISTS' UNION ETC. ETC.

WITH HAND-COLOURED PLATES

BY J. G. KEULEMANS

IN FIVE PARTS

PART I.

WITHERBY \& CO. 326 HIGH HOLBORN LONDON DECEMBER $190 \%$. 



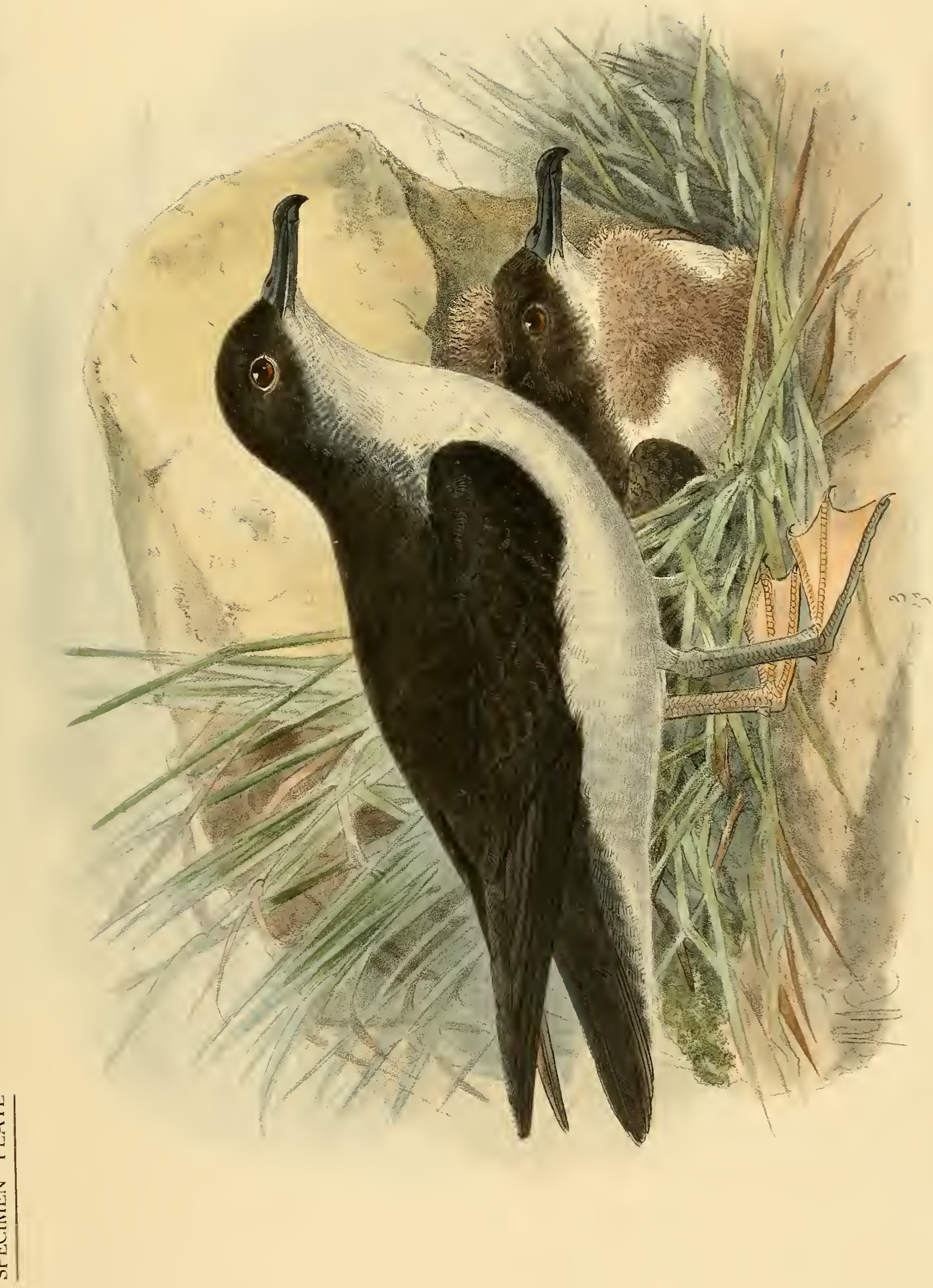






\section{PART I}

\section{CONTENTS}
1. PROCELLARIA PELAGICA
2. PROCELLARIA TETHYS . · · · 4 . 4
3. HALOCYPTENA MICROSOMA • • . 6 . 6
4. OCEANODROMA LEUCORRHOA • . 8 . 4
5. OCEANODROMA BEALI • • • • • 11
6. OCEANODROMA BELDINGI • • • 12
7. OCEANODROMA KEDINGI • • • 13
8. OCEANODROMA CASTRO . • • • $\quad 15$. 5
9. OCEANODROMA MACRODACTYLA . 18 : 5A
10. OCEANODROMA TRISTRAMI . • . 20
11. OCEANODROMA MELANIA • • $\quad$ • $\quad 24$. 6
12. OCEANODROMA MARKHAMI • • $\quad \cdot 27 \cdot 7$
13. OCEANODROMA HOMOCHROA • $\quad 29 \cdot 8$

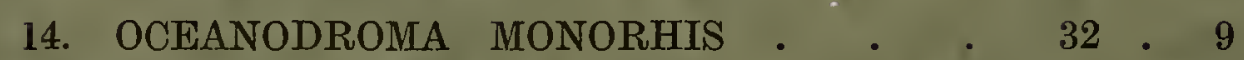
15. OCEANODROMA HORNBYI • • • $\quad 36$. 10
16. OCEANODROMA FURCATA • • • 38 . 11
17. OCEANITES OCEANICUS • • • • • 41,42
18. OCEANITES GRACILIS • $\quad \cdot \quad \cdot \quad \cdot \quad 48 \quad \cdot 13$

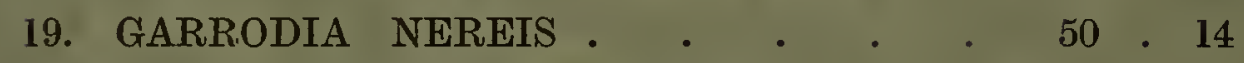
20. PELAGODROMA MARINA . • • . 53.15

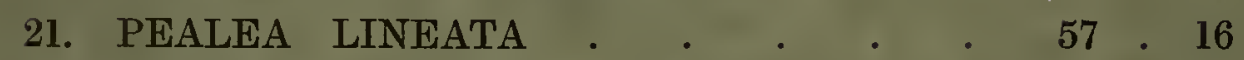
22. CYMODROMA MELANOGASTER • $\quad$. $59 \cdot 17$
23. CYMODROMA GRALLARIA • • . $\quad 65$. 68
24. CYMODROMA ALBIGULARIS . $\quad \cdot \quad \cdot \quad 68 \quad \cdot \quad 19$

PAGE PLATE 
A
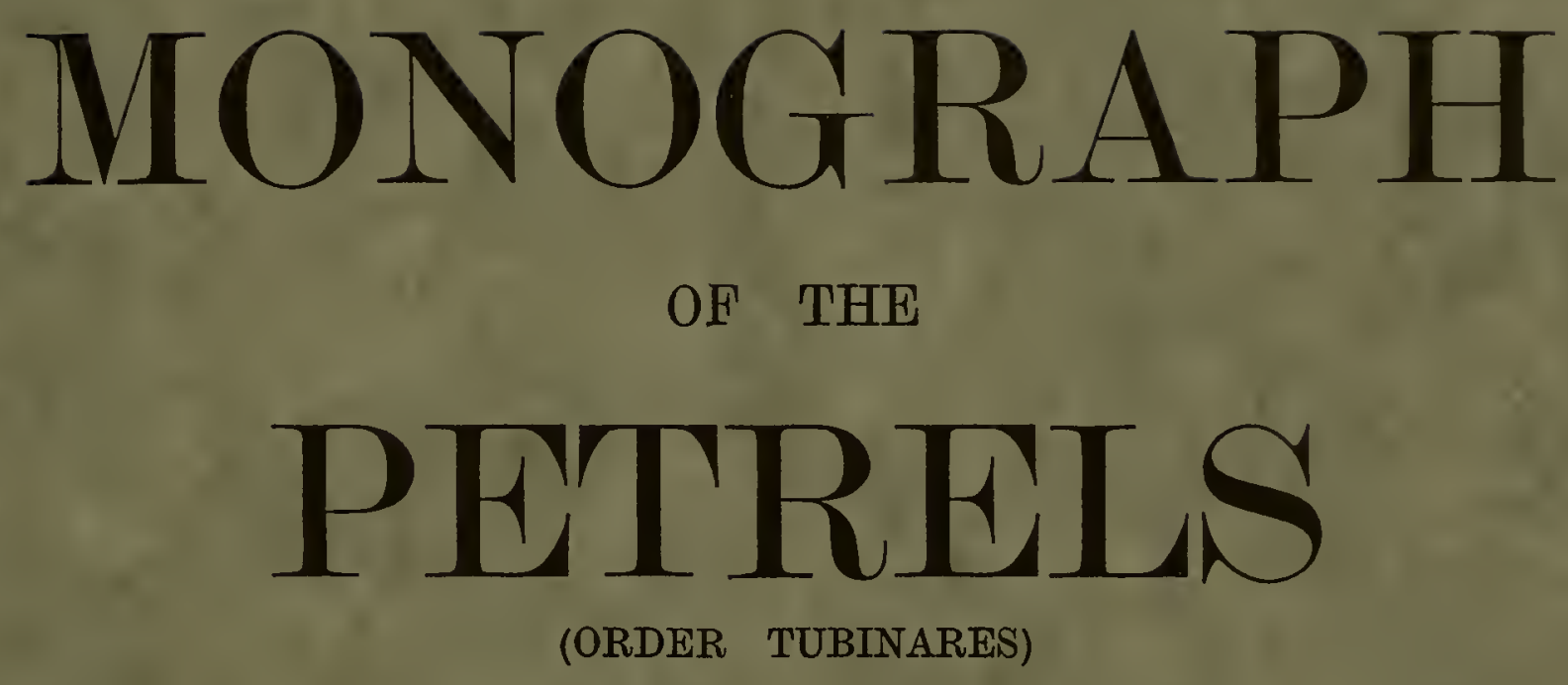

BY

\section{F. DU CANE GODMAN}

D.C.L. F.R.S. PRESIDENT OF THE BRITISH ORNITHOLOGISTS' UNION ETC. ETC.

WITH HAND-COLOURED PLATES

BY J. G. KEULEMANS

IN FIVE PARTS

PART II.

WITHERBY \& CO.

326 HIGH HOLBORN LONDON

MARCH 1908. 




\section{PART II}

\section{CONTENTS}

CYMODROMA ALBIGULARIS-continued . $\quad 69$

25. CYMODROMA MESTISSTMA .. • • 71 . 20

26. PUFFINUS LEUCOMELAS . • • • 72,21

27. PUFFINUS CUNEATUS • • • • $\quad \cdot \quad 76$. 22

28. PUFFINUS BULLERI . • . . • • $\quad$ • 81 • 23

29. PUFFINUS CHLORORHYNCHUS • • 84 . 24

30. PUFFINUS GRAVIS • • • • •

31. PUFFINUS KUHLI • • • • • • $\quad$ • 94 • 26

32. PUFFINUS EDWARDSI $\quad \cdot \quad \cdot \quad \cdot \quad \cdot \quad \cdot \quad 99$

33. PUFFINUS CREATOPUS . • • • • 101 . 27

34. PUFFINUS ANGLORUM • • • • • $\quad$ • 104 . 28

35. PUFFINUS YELKOUANUS $\quad \cdot \quad \cdot \quad \cdot \quad 107 \quad \cdot 29$

36. PUFFINUS OPISTHOMELAS $\quad \cdot \quad \cdot \quad \cdot \quad 109$. 30

37. PUFFINUS AURICULARIS · • . 112 . 31

38. PUFEINUS NEWELLI • . . $\quad 115$

39. PUFFINUS SUBALARIS $\quad \cdot \quad \cdot \quad \quad \quad 117$

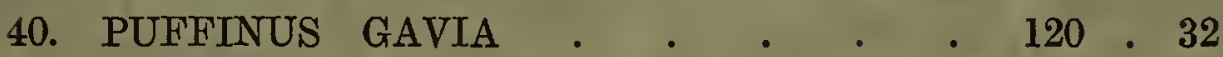

41. PUFFINUS PERSICUS.$\quad \cdot \quad \cdot \quad \cdot \quad 124$. 33

42. PUFFINUS OBSCURUS $• . \quad \cdot \quad . \quad 126 \ldots 34$

43. PUFFINUS AUDUBONI • • • • $\quad \cdot 129$

44. PUFFINUS ASSIMILIS $• \quad \cdot \quad \cdot \quad \cdot 133.35$

45. PUFFINUS ELEGANS. • • • • ‘ 136 • 36

46. PUFFINUS BAILLONI • • • •

47. PUFFINUS CARNEIPES · • • • $\quad \begin{array}{llll} & 142 & 37\end{array}$

48. PUFFINUS GRISEUS • • • • • • 145 . 38

49. PUFFINUS TENUIROSTRIS $\cdot \cdot \quad \cdot \quad \cdot 149,39$ 






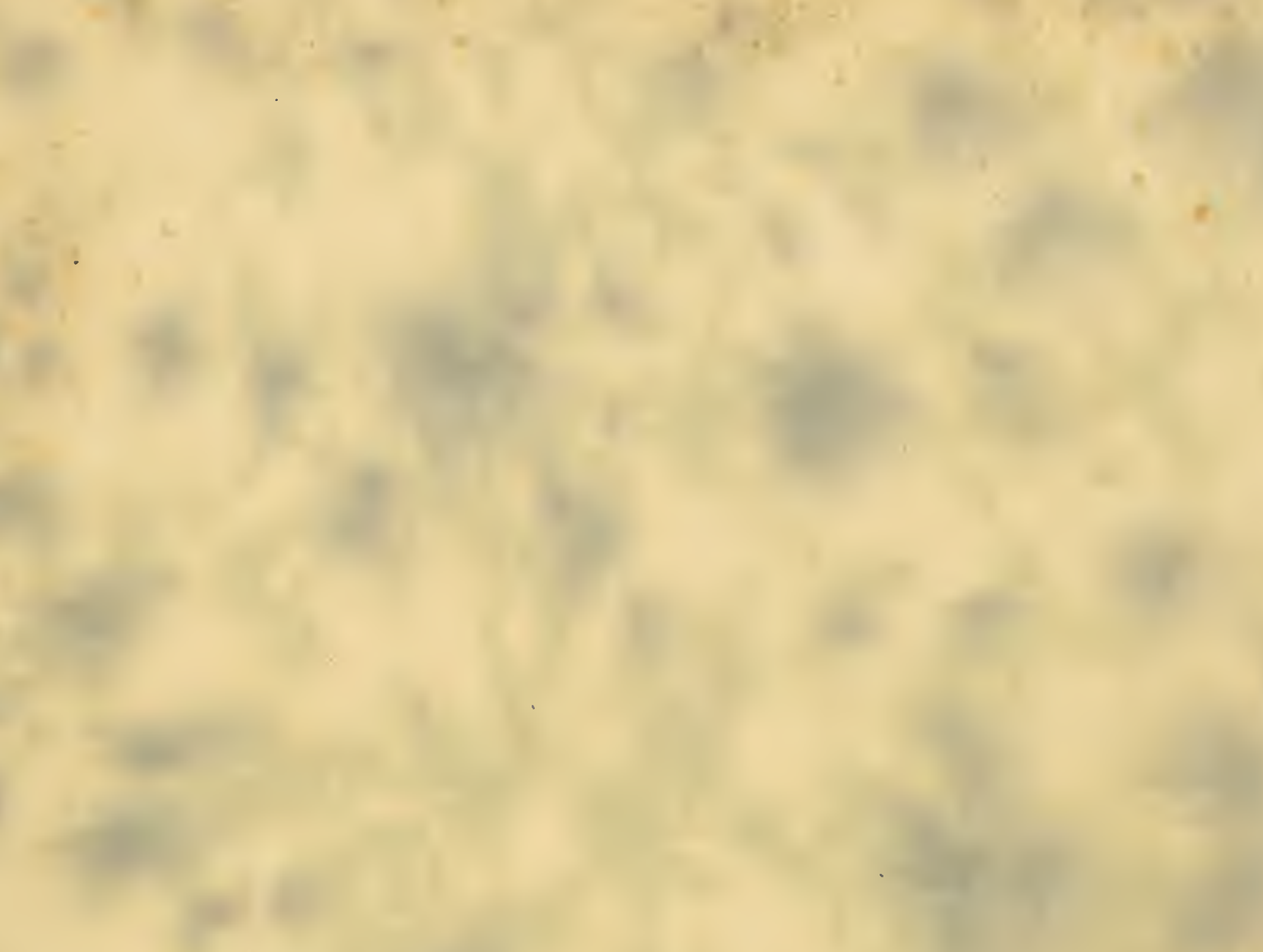


